Raphael Foli Fiagbomeh

PERCEPTIONS OF THE IMPACTS

OF NATURE CONSERVATION

AND ECOTOURISM

MANAGEMENT

A Case Study in the Kakum Conservation Area of Ghana

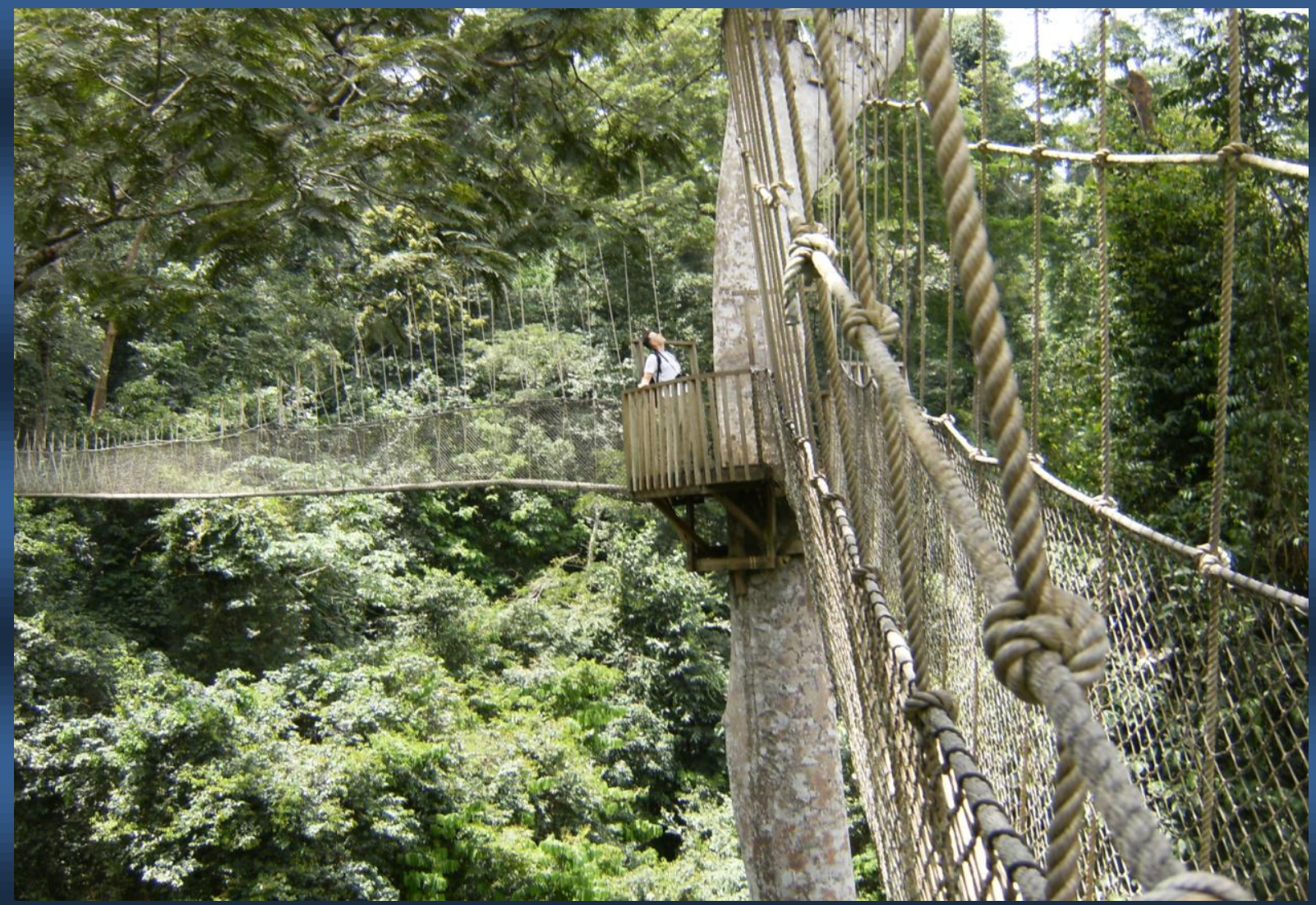




\title{
PERCEPTIONS OF THE IMPACTS OF NATURE CONSERVATION AND ECOTOURISM MANAGEMENT: \\ A CASE STUDY IN THE KAKUM CONSERVATION AREA OF GHANA
}

\author{
DISSERTATION \\ submitted at the \\ Department of Nature Conservation and Landscape Management, \\ Faculty of Forest Sciences and Forest Ecology, \\ Georg-August of University Göttingen \\ in partial fulfilment for the award of Doctor of Philosophy (Ph.D.)
}

By

Raphael Foli Fiagbomeh

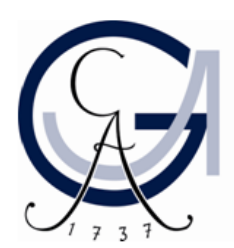

December 2012

Göttingen, Germany 


\section{Examiners:}

1. Prof. Dr. Renate Bürger-Arndt

2. Prof. Dr. Max Krott

3. Prof. Dr. Ralph Mitlöhner

Date of Examination: 14 ${ }^{\text {th }}$ December 2012 


\section{Acknowledgement}

This Ph.D research would not have been possible without the support, guidance and encouragement of several people. To all these people, I wish to express my profound gratitude. First of all, I wish to thank my major supervisor, Prof. Dr. Renate Bürger-Arndt who accepted and encouraged me to carry out this thesis research. I am grateful for her insights, guidance and constructive comments which helped considerably to improve the applied methodologies and the scientific content of the thesis. My special appreciation and thanks also go to Prof. Dr. Max Krott (Department of Forest and Nature Conservation Policy) and Prof. Dr. Ralph Mitlöhner (Department of Tropical Silviculture and Forest Ecology), who supported me as second and third supervisors respectively and for being members of my doctoral examination committee.

An important institution to acknowledge is the Evangelisches Studienwerk e. V. (Villigst). This PhD research could not have taken place without the financial support provided by Villigst. I am grateful to the supportive and friendly staff of Villigst, particularly Prof. Dr. Eberhard Müller for all his assistance and advice throughout the scholarship period.

I wish to also extend my special thanks to the Wildlife Division staff at Kakum Conservation Area in Ghana. Of particular mention is Mr. Edward Wiafe (In-charge of Law Enforcement) for responding to all my queries and the insightful discussions during my field work in Kakum. I am also grateful to Mr. Daniel Ewur (Park Manager), Mr. Joseph Binlinla (Collaborative Resource Manager), and Mrs. Tina Anie Sampah (Visitor Relations Officer) for their support during the data collection. I am also indebted to Mr. Oti Awere (Commercial Development Unit) and Mr. Andrew Agyare (Collaborative Resources), both at the Wildlife Division Headquarters in Accra, and Mr. Cobbinah (Director, Ghana Heritage Conservation Trust, Cape Coast) for granting me interviews during the research and sharing their thoughts on protected areas management and ecotourism development in Ghana. To all the chiefs, opinion leaders, informants and the heads of households who availed themselves to me during the data collection, I say a big thank you. Without your support, the data collection would not have been successful.

Thank you to all former and current colleagues at the Department of Nature Conservation and Landscape Planning, at the Faculty of Forest Sciences and Forest Ecology, namely: Dr. Ju-Hyoung Lee, Jan-Carl, Christoph, Silas, Ulrike, Linda, Dr. Bernd Gehlken, Benjamin, Katharina, Jochen, FOR Rolf Clauditz, Bettina and Mai for all your kindness and encouragement. I was also fortunate to experience the friendship of my lovely people including: Dr. Sam Essiamah, Abdussamad, Anne, Hope, Amos, Jagriti and Cesar who was especially helpful in sorting out all my computer software challenges.

My deepest appreciation goes to my mother Grace Ntow, Susanne Pauli, my little daughter and angel Amadea, and all my siblings for their patience, encouragement and support. May God bless you all for the incredible kindness and support you have provided me during my PhD studies. Finally to the Lord almighty, I am extremely grateful for granting me life and providing me with the strength to undertake this PhD studies to a successful end. 


\section{Summary of Research \\ Introduction}

In recognition of the livelihood needs of local people that undermine non-use conservation objectives, protected areas are now said to have assumed a mandate to go beyond just biodiversity conservation to improving the welfare of local people through the provision of economic benefits across multiple scales. But in order to achieve the new mandate of protected areas, there is a paradigm shift that seeks to promote a model of biodiversity conservation where livelihood activities are not just seen as compatible with biodiversity conservation but that it actually drives and facilitates conservation objectives. Consequently, among livelihood activities that have the potential to provide the necessary livelihood benefits or incentives, ecotourism is thought to be the most appropriate one to better serve this purpose. Ecotourism, when properly developed and managed, can play a mediating role between the interests of protected area management and local people and as well give an exciting nature experience to tourists. However, to achieve this mediating role, ecotourism development in any destination would require appropriate participation of all stakeholders. In essence, there should be a harmonious relationship between the resources (protected area), local people and ecotourism, facilitated by appropriate management strategies.

The ecotourism subsector in Ghana is being vigorously promoted as a means to finance nature conservation and to facilitate local area development. However, like any other venture, there is the need to subject ecotourism development to rigorous evaluation to ascertain whether it is achieving the objectives of the concept. It is believed that apart from the unique features and experience that protected areas might present to the tourist, the prospects of ecotourism will depend on how to: i) sustain the interest of visitors in order to inspire them for future return visits and the ability to attract potential new visitors; and ii) engender the support of local people for conservation by effectively involving them so that they could share in the socio-cultural and economic benefits as a result of protecting the area. This is only possible when there is the right framework for managing the interactions and impacts. The study adopted a theoretical evaluative framework that assesses the impacts of ecotourism. Through the evaluative framework, a site-level evaluation of nature conservation and ecotourism in the Kakum Conservation Area (KCA) of Ghana was undertaken to assess the status and underscore the current relationship between local people, resources and ecotourism in the Kakum conservation area. 


\section{Research Objectives}

The central focus of the study is to evaluate the perceptions of impacts of ecotourism and nature conservation management in the Kakum Conservation Area, Ghana. The ultimate goal is to evaluate the prescriptive potential and the opportunity costs of ecotourism development and protected area management in natural resource dependent communities. With the aim of identifying at the end, strategies to optimise the contribution of ecotourism to protected area conservation and development of destination communities, the specific objectives of the study were to:

1) Determine the host communities' perceptions of ecotourism, and their values and relationships with the natural resources within the protected area.

2) Determine the change in the economic benefits from the protected areas due to ecotourism and its distribution and impact on the local communities.

3) Offer planning and management recommendations to the destination's administrative bodies to facilitate conservation and sustainable development initiatives in the local communities.

The study examined the existing relationships in order to provide practical planning directions to park/conservation area managers to will enhance the capacity of ecotourism to generate benefits for both the local communities and the park, and thus contribute to sustainable development efforts in the country.

\section{Methodology}

To ascertain the status of ecotourism and the combined impacts of ecotourism and nature conservation management, the study employed multiple methodological approaches to collect both primary and secondary data for analysis. A survey of tourists was conducted at the visitor centre and a community survey of residents was also conducted in eight communities adjacent to the protected area. Altogether, 423 tourists participated in the survey at the visitor centre while a total of 141 local residents took part in the community level surveys. The conservation area officials and some chiefs and elders of the local communities were also interviewed. Beyond these, group discussions were held in the communities to understand the popular opinions of the local people about conservation and ecotourism activities in Kakum. Subsequently, in order to propose strategic options to facilitate nature conservation and ecotourism management, a hybrid SWOT and AHP analysis was also conducted. 


\section{Results}

Local People and Conservation: The community surveys revealed that the current ecotourism and protected area management schemes neglects the traditional institutional structures whose involvement could facilitate and solicit local people's support for conservation. There is also a communication gap and lack of effective programmes to stress the importance of community level cooperation in conservation. Again, the community surveys confirmed that local people have been denied rights to collect NTFPs on which they previously depended for livelihood support. Thus some livelihood activities in adjacent communities have changed since the creation of the conservation area. In fact, a majority (89.4\%) of respondents emphasised that community interests are not factored into the management of the area. Although the local people have lost their access and use rights and also do not benefit from ecotourism, over $97 \%$ of respondents appreciated the importance of the protected area while over $88 \%$ expressed interest to participate in the management if given the opportunity. In spite of the expressed interest, although law enforcement through day and night patrol has increased, illegal activities still remains high in the conservation area as compared to the acceptable national level.

Local People and Ecotourism: Ecotourism at the moment does not play any meaningful role in securing the livelihood of the local people and neither is it contributing to the development of the local communities. The study established that there is a weak interaction between local people and tourism as well as local people and resources, due to the apparent neglect by management authorities. Consequently, the study noted that the local people rather have reservations concerning the impacts of ecotourism on their livelihood. Although the majority of household respondents never engaged in any livelihood activity related to ecotourism, they were hopeful of possible benefits they could derive from provision of services and therefore demanded that ecotourism activities be expanded to include tourist visits to their communities. Aside the lack of economic benefits, conservation education which is one of the tenets of ecotourism is also lacking. Therefore $75 \%$ of the community respondents were of the view that effective outreach programmes and involvement could motivate resident local people to guard the area and reduce illegal or poaching activities.

Ecotourism and Tourists: The number of tourists visiting Kakum, according to the visitor records, has progressively increased since the introduction of tourism. The tourist survey on the other hand revealed that Kakum is mainly patronised by first time visitors as indicated by $84 \%$ of the survey respondents and they mostly spent less than three hours on site. In spite of the relative short time spent on site, results show that $91.5 \%$ of the survey respondents were satisfied with their recreational experience in Kakum. As a confirmation of their satisfaction, the majority (90.5\%) of the 
respondents indicated that they would recommend Kakum as a must visit ecotourism site in Ghana. Nonetheless, over $54 \%$ of the respondents expressed disagreement with the restrictions instituted by the management authorities on movements within the park while $67.5 \%$ expressed interest in additional alternative activities related to wildlife observation or tracking. At the moment, the canopy walk continues to be the main attraction. Apart from attracting smaller numbers of tourists, the nature walk has experienced a sharp decline in tourist interest since 2004. This makes it important to consider the expressed interest in additional activities. Further analysis indicated that interest in additional activities decreased with increasing age of the respondents. Organised visits to adjacent communities and farms are also valuable options that would expose particularly the curious non-Ghanaian visitors to rural life in Ghana and as well offer opportunity for the local people to be involved in ecotourism and conservation management. Currently, the situation in Kakum is such that there is practically no interaction between local residents and tourists in order to facilitate intercultural appreciation as propounded by the ecotourism concept.

\section{Conclusion}

In assessing all the interactions indicative of ecotourism, it is obvious that the interaction between ecotourism, resources and local people in the Kakum conservation area is not symbiotic or harmonious. But in considering that in spite of all the challenges the local people still have positive attitudes towards ecotourism and conservation, the study concluded that active involvement of local people in ecotourism activities would solicit much more positive attitude towards biodiversity conservation, aid local area development and ensure a quality tourist experience. Hence, the managers of Kakum Conservation Area need to consider and develop the proposed management enhancing strategies to actively involve the local communities and thereby elicit their genuine support for the area's protection from "external local poachers" and thus create a win-win ecotourism-protected area management in the Kakum Conservation Area. 


\section{TABLE OF CONTENTS}

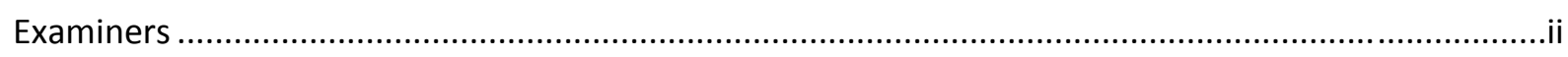

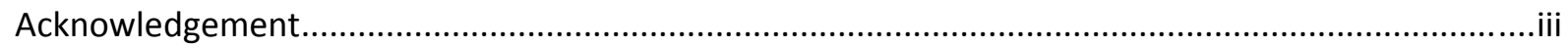

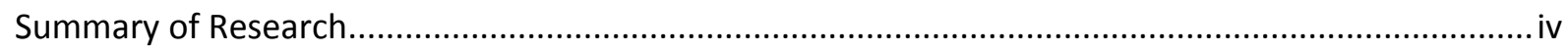

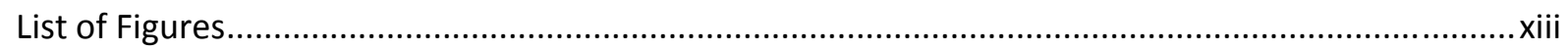

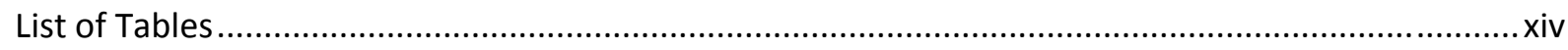

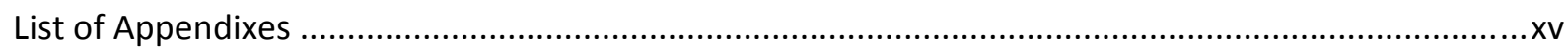

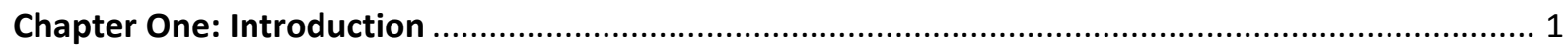

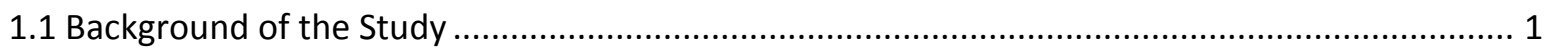

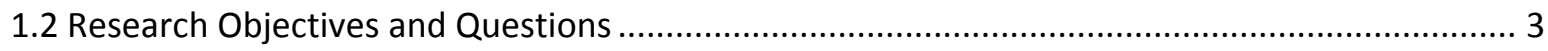

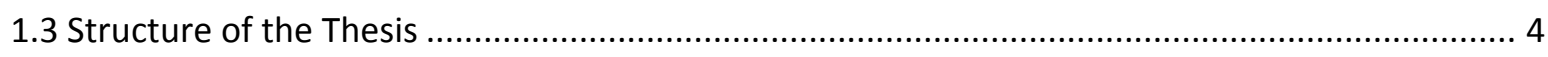

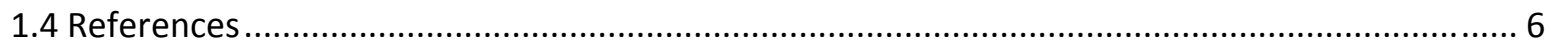

Chapter Two: The Conceptual Framework of Ecotourism .......................................................... 7

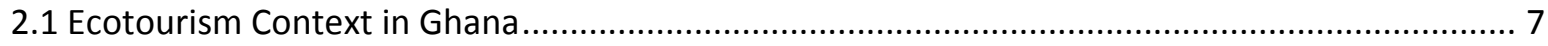

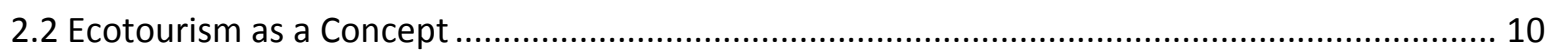

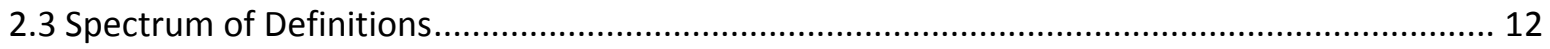

2.4 General Objective of Ecotourism Management................................................................... 17

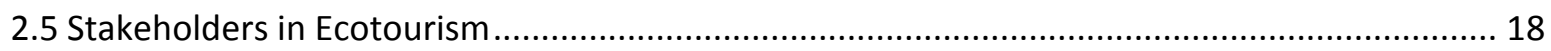

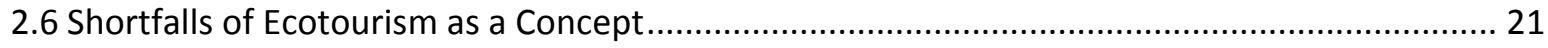

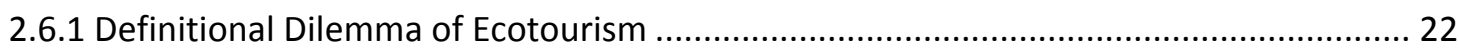

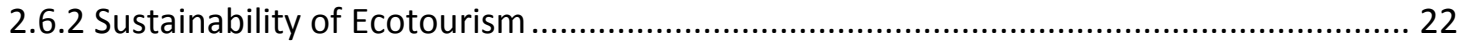

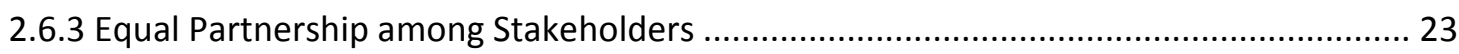

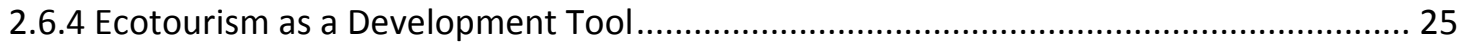

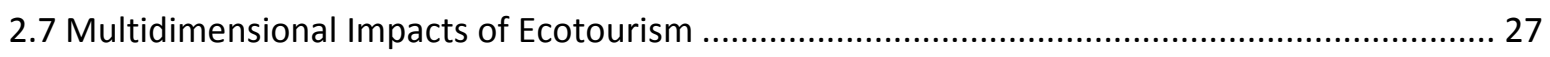

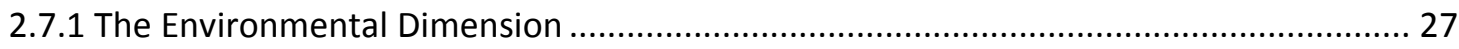

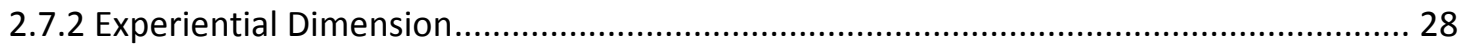

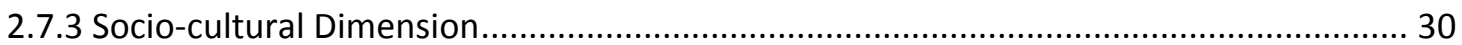


3.2 Theoretical Framework and Indicators for Assessing Ecotourism Impacts. 40

3.2.1 Local People/Communities and Protected Areas................................................ 43

3.2.2 Ecotourism and Protection of Natural Resources ................................................. 44

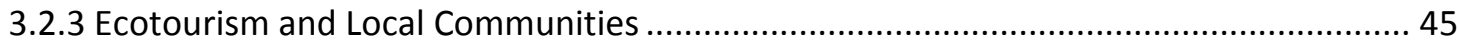

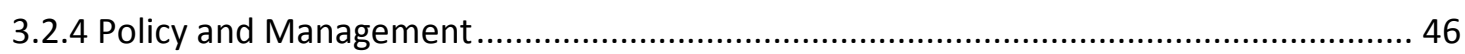

3.3 Institutions and the Policy Framework for Tourism Development .................................47

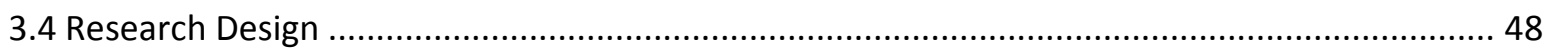

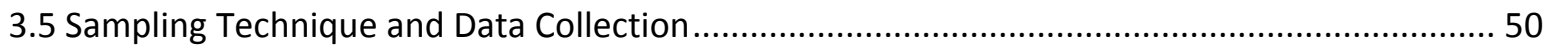

3.5.1 Primary Data Collection ............................................................................... 51

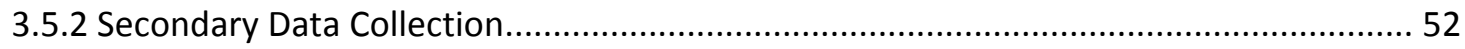

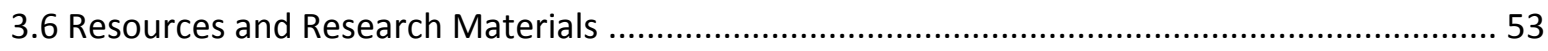

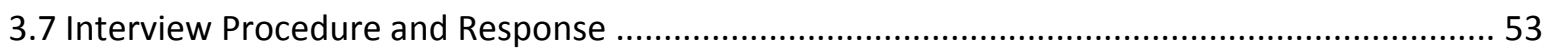

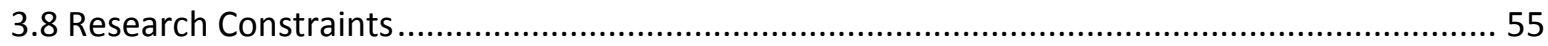

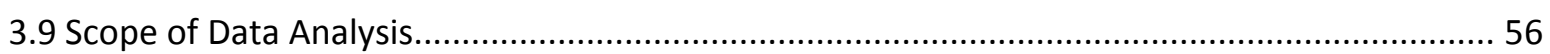

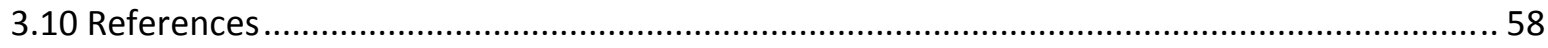

Chapter Four. The Protected Area System of Ghana and the Study Area ................................6 60

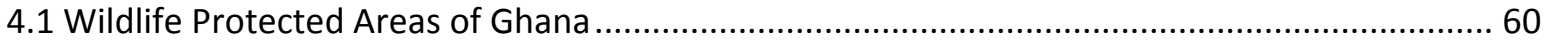

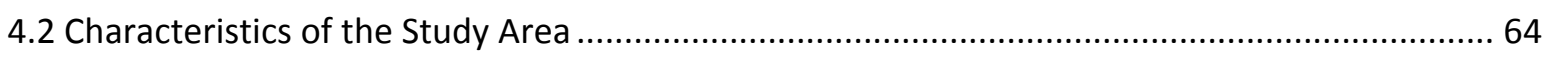

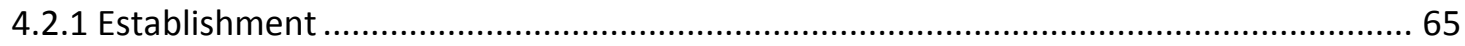

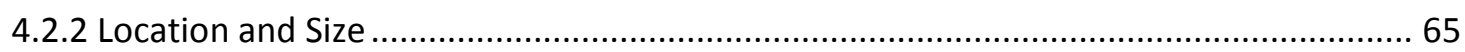

4.2.3 Topography and Climatic Characteristics ........................................................ 65

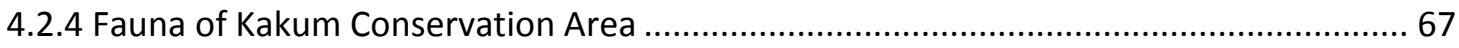

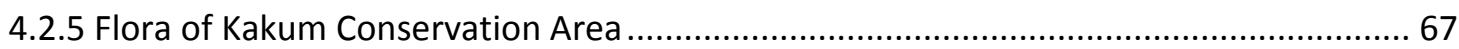


4.3 Management Objectives for the Kakum Conservation Area.....

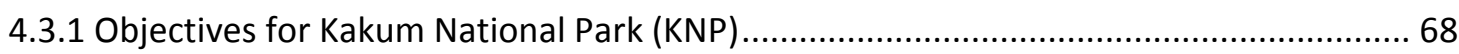

4.3.2 Objectives for Assin Attandanso Resource Reserve (AARR)...................................69

4.4 Management Activities in Kakum Conservation Area ...................................................... 70

4.4.1 Protection and Law Enforcement ............................................................... 70

4.4.2 Ecotourism Development in the Kakum Conservation Area ..................................... 74

4.5 Socio-Economic Context and Livelihoods in the Kakum Conservation Area.............................. 75

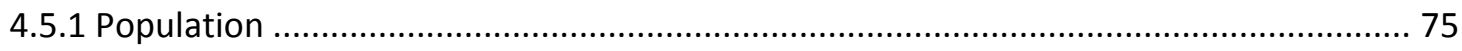

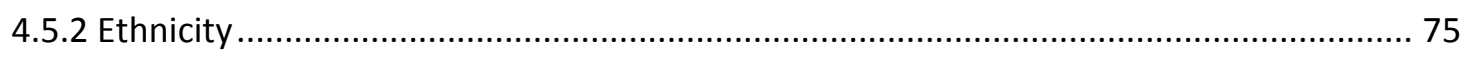

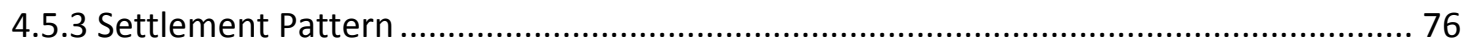

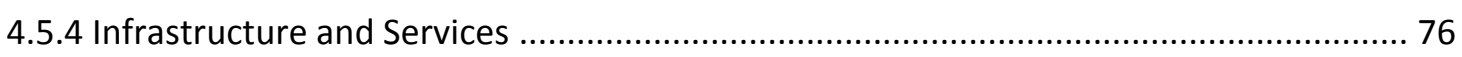

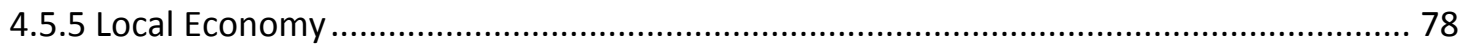

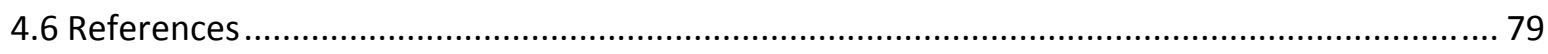

Chapter Five: Local Community's Needs and Perceptions Concerning Kakum Conservation Area and its Management - Challenges and Opportunities for Integration .......................................... 81

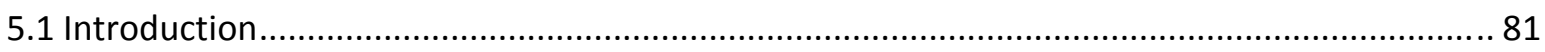

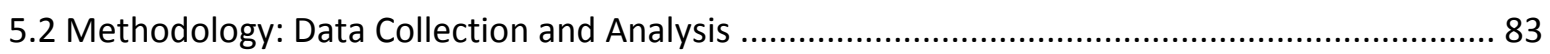

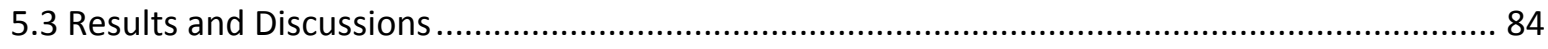

5.3.1 Livelihood Activities of Local People ............................................................... 84

5.3.2 Perceptions of Local People Concerning the Impact of Kakum Conservation Area........86

5.3.3 Local Peoples' Appreciation of Kakum Conservation Area .......................................... 90

5.3.4 Perceptions of Local People Concerning Kakum Conservation Area Management........ 91

5.3.5 Local Peoples' Involvement in Protected Area Management .................................. 92

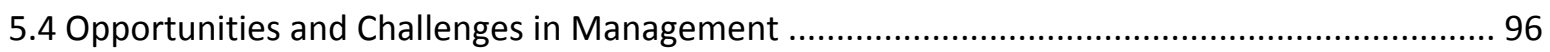

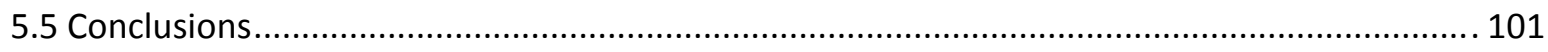

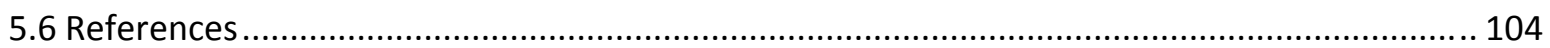




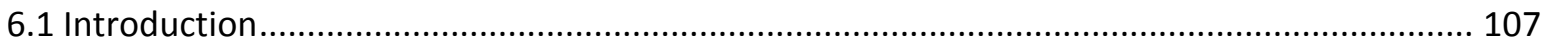

6.2 Methodology: Data Collection and Analysis ............................................................ 109

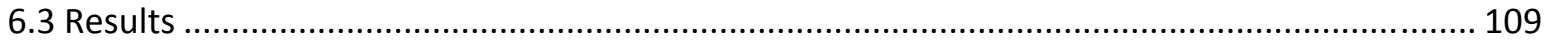

6.3.1 Demographic Characteristics of Respondents ................................................ 109

6.3.2 Motivation, Activities and Trends of Visitation ................................................. 111

6.3.3 Visitor Itineraries and Preferences .............................................................. 114

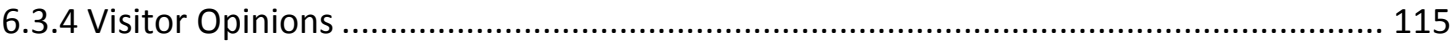

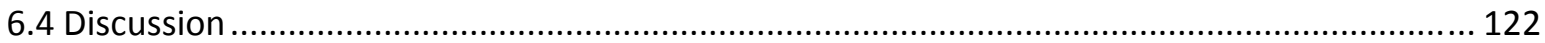

6.5 Conclusion and Recommendations for Management................................................. 124

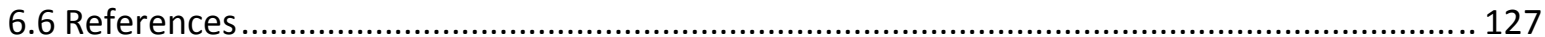

Chapter Seven: Local Community's Perceptions of Impacts and their Attitudes Concerning Ecotourism in the Kakum Conservation Area - Opportunities for Participation ......................... 129

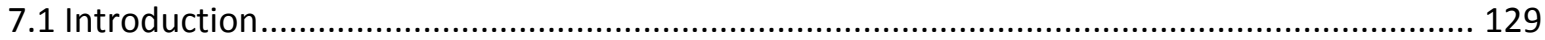

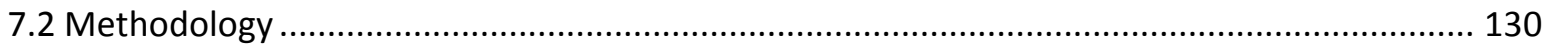

7.2.1 Sampling and Data Collection....................................................................... 130

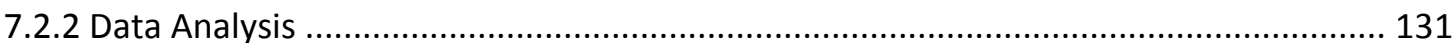

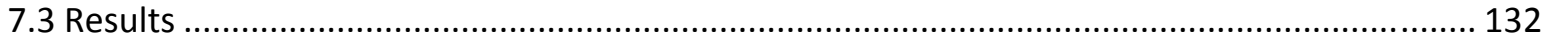

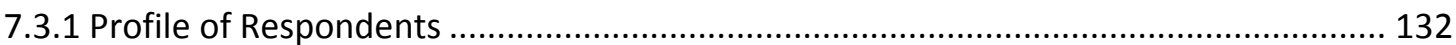

7.3.2 Perceived Impacts of Ecotourism ............................................................ 134

7.3.3 Attitudes of Local People and Desirable Future for Ecotourism ............................... 137

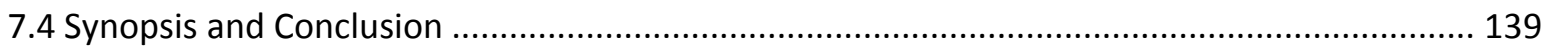

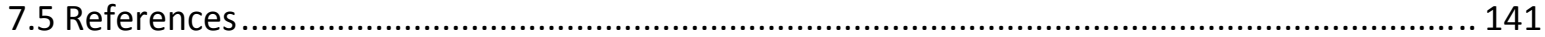

Chapter Eight: Status of Ecotourism in the Kakum Conservation Area ................................... 143

8.1 The Relationship Status of Ecotourism in Kakum Conservation Area ................................. 143

8.2 Local People and the Kakum Conservation Area ...................................................... 144

8.3 Ecotourism and Protection of Natural Resources ....................................................... 145 
8.5 Management Role of Authorities ............................................................................ 149

Chapter Nine: Assessment and Recommendations for Future Strategic Management Planning in

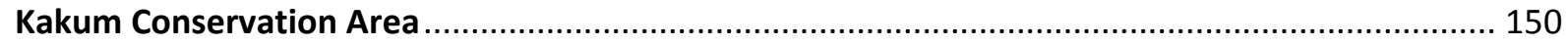

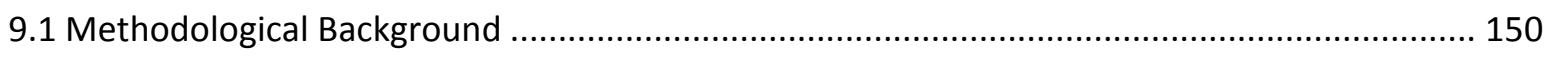

9.1.1 The Analytic Hierarchy Process (AHP) ........................................................ 150

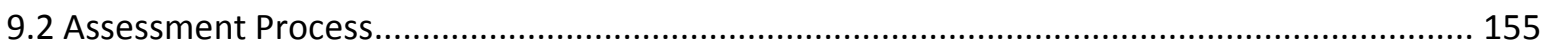

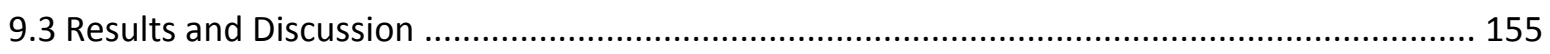

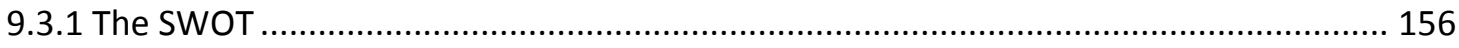

9.3.2 The Possible TOWS Strategies ................................................................... 159

9.3.3 Application of AHP to the TOWS Strategies ................................................... 163

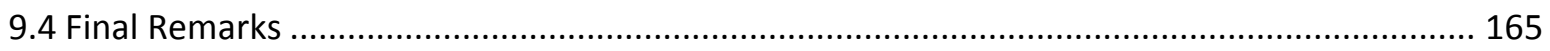

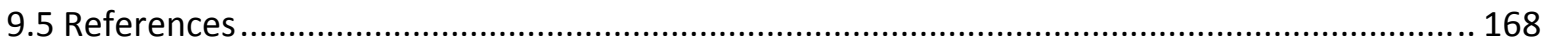




\section{List of Figures}

Figure 3.1 A Conceptual Framework for Analysing the Impact of Ecotourism........................................42

Figure 4.1 Map of Wildlife Protected Areas and Ecotourism Sites in Ghana..........................................62

Figure 4.2 Map of Kakum Conservation Area Showing Some Major Communities.................................66

Figure 4.3 Effective Patrol Man-days per Month in Kakum....................................................................71

Figure 4.4 Encounter Rate with Illegal Activities in Kakum Conservation Area........................................71

Figure 4.5 A Comparison of Encounters with Cartridges and Snares in 2007........................................73

Figure 4.6 A Comparison of Encounters with Cartridges and Snares in 2008........................................73

Figure 4.7 Proportions of Serious Offences (Illegal Activities) Encountered per Year.............................74

Figure 5.1 Comparison of Livelihood Activities in Kakum Conservation Area..........................................84

Figure 5.2 Land Ownership Among Respondents per Community.......................................................85

Figure 5.3 Conservation Education in KCA Communities.....................................................................94

Figure 5.4 Family Relations and Friends in other Communities within Kakum Conservation Area......97

Figure 6.1 Trends of Visitation in the Kakum Conservation Area........................................................112

Figure 6.2 Trends of Visitation in Canopy Walk...............................................................................113

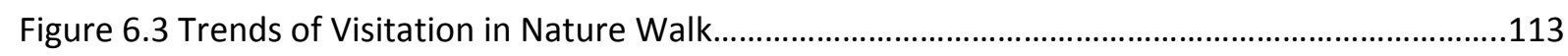

Figure 7.1 Perceptions of Ecotourism Impact on the Community and Livelihoods..............................135

Figure 7.2 Identified and Desired Opportunities in Ecotourism.............................................................138

Figure 7.3 Identified Impediments to Working in Ecotourism..............................................................139

Figure 8.1 Framework of Current Status of Relationships in Kakum Conservation Area......................143 


\section{List of Tables}

Table 2.1 Concept and Definitions of Ecotourism ..............................................................................15

Table 2.2 Summary of the Generally Anticipated Benefits and Costs of Ecotourism .............................33

Table 3.1 Resources and Materials used during fieldwork .................................................................53

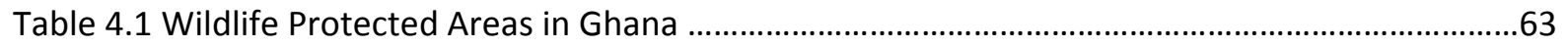

Table 5.1 Livelihood Activities of Respondents in the Local Communities ............................................84

Table 5.2 Local Peoples' Perceptions of the Conservation Effects at KCA …..........................................87

Table 5.3 Local Peoples' Attitude towards Nature Conservation ..............................................................89

Table 5.4 Importance of Conservation Area to Local People .................................................................91

Table 5.5 Willingness for Awareness and Participation in Management .............................................93

Table 6.1 Chi-square Test of the Relationship between Demographic Variables and

Desire for More Recreational Opportunities by respondents resident in Ghana

Table 6.2 Chi-square Test of the Relationship between Demographic Variables and

Desire for More Recreational Opportunities by respondents from foreign countries

Table 6.3 Residents' Level of Satisfaction (\%) with Recreational Experience in Kakum .......................116

Table 6.4 Non-residents' Level of Satisfaction (\%) with Recreational Experience in Kakum

Table 6.5 Level of Agreement (\%) by Respondents Resident in Ghana with Factors Related to Satisfaction in Kakum

Table 6.6 Level of Agreement (\%) by Respondents Resident in Foreign Countries with Factors Related to Satisfaction in Kakum ......

Table 6.7 Summarised Aspects of Interpretation Offered by Tour Guides

Table 7.1 Demographic Characteristics of Community Respondents

Table 7.2 Characteristics of Study Community .133

Table 7.3 Local Peoples' Attitude Concerning Tourism in KCA ..........................................................136

Table 7.4 Relationship between Local People and Ecotourism .............................................................137

Table 8.1 Community Members' Opinions of Ecotourism and Protected Area Management ............144

Table 8.2 Community Residents' Perception of the Environment and Tourism Relationships ...........146

Table 9.1 Saaty's 1 - 9 Fundamental Scale for AHP Preference ............................................................154

Table 9.2 A SWOT Analysis of Biodiversity Protection in the Kakum Conservation Area .....................156

Table 9.3 A SWOT Analysis of Tourism Management in the Kakum Conservation Area .......................157

Table 9.4 Combined SWOT and TOWS Analysis of Biodiversity Conservation and Tourism Management in Kakum 160

Table 9.5 Priorities and Consistency Ratios of Comparisons of the TOWS groups and factors .164 


\section{List of Appendixes}

Appendix One: Questionnaires for local community survey

Appendix Two: Questionnaires for tourist survey

Appendix Three: Guide questions for informants and group discussions 180

Appendix Four: Guide questions for interviewing Park officials 181

Appendix Five: General criteria and indicators for ecotourism assessment 182

Appendix Six: Details of the Outputs in the Analytical Hierarchy Process (AHP) Analyses .190

Appendix Seven: Curriculum Vitae 201 


\section{Chapter One: Introduction}

\subsection{Background of the Study}

Ensuring local support for protected areas is increasingly viewed as an important element of biodiversity conservation. This is often predicted on the provision of benefits from protected areas, and a common means of providing such benefits is ecotourism development. The concept of ecotourism has received much attention in the past decades due to its link with sustainable development initiatives, protected area conservation efforts, and regional and community development strategies, particularly in developing countries (Ceballos-Lascurain, 1993).

In many African countries, the rationale for ecotourism development is primarily economic, at both the macro (national) and micro (local) levels. At the macro level, ecotourism is expected to promote economic growth by generating foreign exchange and increase government revenue while at the micro level, it is expected to facilitate job creation, income and revenue distribution and a balanced regional development which ultimately should improve quality of life of local residents (Sirakaya et. al., 2002). In addition, it is to provide revenue for the creation and maintenance of protected areas (Boo, 1990). Since the late 1980s, tourism (ecotourism) has received considerable promotion in the economic development strategy of Ghana (Sirakaya et. al., 2002) as a response to the adverse developments that occurred in its economy. The rationale was to diversify the economy to reduce its dependence on traditional exports of unprocessed precious minerals, agricultural and forest products (Teye, 2000) and to facilitate its sustainable development process.

In spite of the perceived benefits of ecotourism, Stone and Wall (2003) have noted that the impact of ecotourism has been quite variable. There are evidences that ecotourism can achieve its touted benefits (Eagles et. al., 2002; Slinger, 2000), but there are equally as many cases if not more where ecotourism has failed to achieve its set objectives (Nepal, 2000; Ross and Wall, 1999b). There are observations, also in Ghana, that the promotion of ecotourism and for that matter the establishment of protected areas has excluded local customary uses of natural resources including people losing agricultural land and livelihoods which the concept should rather promote. For some areas, it has been a source of local conflicts, and breakdown of local institutions as well as a source of abuse of local institutional power and deterioration in community cohesion (Edelman, 2006).

Allen, et. al. (1988) observed that many state and local governments attempt to optimise economic benefits of ecotourism with little regards to the social and ecological costs. Therefore, the eagerness 
of governmental and allied organisations to accelerate the development of ecotourism (particularly in Ghana) raises several questions such as:

i. Is ecotourism really contributing to sustainable development at the local level?

ii. How viable is ecotourism as a strategy for community development?

iii. What have the socio-cultural impacts of ecotourism been? or,

iv. Has ecotourism development encouraged or improved the conservation of protected areas?

Although some of these questions have been addressed to some extent in the literature, Ross and Wall (1999a) have criticized the lack of practical assessments of ecotourism status and real impacts at the local level or specific destination areas. There are relatively few if any of such studies on the dimensions of the impacts at the local level in Africa, and especially in Ghana, where ecotourism development is receiving much attention. Often, the communities are restrained from certain uses of their local environment which causes disruptions in the socio-cultural environment. To address this gap in theory and practice, Stone and Wall (2003) suggested that the impact of ecotourism at specific destinations in developing countries must be researched. It is particularly important to conduct such a study in Ghana since there has been a lot of effort to develop the industry but there are evidence of apathy and conflicts in some destinations (Nature Conservation Research Centre, 2004; Edelman, 2006) which are worth looking into. The Nature Conservation Research Centre Ghana report (2004) for example, mentioned that rivalry between two communities, Boaben and Fiema, is affecting the management of their monkey sanctuary as an ecotourism destination due to different objectives and expectations which are not being met. Further, there are also reported cases of poaching in some ecotourism protected areas indicating that local people are being denied the use of resources with no adequate substitute or compensations. This and many other situations need to be studied within the local context and appropriate measures need to be implemented to ensure that local people benefit rather than suffer from ecotourism development. In the effort to study and improve ecotourism delivery at the local level, there is the need for the establishment and use of standard assessment methods which would facilitate comparison. Besides, after about two decades of ecotourism activities in Ghana, there are no studies that have assessed the dimensions of the true impacts of ecotourism development on specific destination communities.

Given the above premise, this study examines the socio-cultural, economic and environmental impacts of ecotourism in Ghana and evaluates its prescriptive potential and contributions to conservation of protected areas. Hence it analyses the impacts in selected rural communities located 
around the Kakum Conservation Area (KCA) as one of the most visited ecotourism destination in Ghana. This assessment of the current status of ecotourism in the KCA will hopefully serve as a base on which further developments can be compared and appropriate actions be engendered in order to prevent potential negative impacts and promote conservation and sustainable development initiatives.

\subsection{Research Objectives and Questions}

The central focus of the study is to evaluate the performance of ecotourism through an evaluation of the impacts on protected areas and adjacent communities where it is being promoted as a sustainable development strategy. The ultimate goal is to evaluate the prescriptive potential and the opportunity costs of ecotourism development in natural resource dependent communities. With the aim of identifying at the end, strategies to optimise the contribution of ecotourism to protected area conservation and development of destination communities, the study would undertake to determine:

1) The host communities' perceptions of ecotourism, and their values and relationships with the natural resources within the protected area. It is expected that there will be positive attitude by the communities towards conservation as a result of increased benefits derived from the protected area, which should improve the ecological values such as species richness, ecosystem integrity and resilience in the protected area. It is important to identify the change in the ecological values experienced in protected areas due to ecotourism development and activities. The questions to be answered are:

i. What are the communities' perceptions of ecotourism and values of the protected area?

ii. Has ecotourism development improved or encouraged conservation of the protected area?

2) The change in the economic benefits from the protected areas due to ecotourism and its distribution and impact on the local communities. Developing ecotourism in some areas would call for some local residents losing their original source of livelihood and creating disruptions that could make the community a less desirable place to live. Therefore it is envisaged that where local people do not receive benefits from protected areas, they are likely to compete with the tourism industry for the use of scarce natural resources. Under this objective, two questions will be answered:

i. Are there disruptions or changes in livelihood strategies, and if so, what are the new 
adaptations in the communities?

3) Offer planning and management recommendations to the destination's administrative bodies to facilitate conservation and sustainable development initiatives in the local communities.

This study would examine the existing relationships and is expected to provide practical planning directions to park/conservation area managers that will enhance the capacity of ecotourism to generate benefits for both the local communities and the park, and thus contribute to sustainable development efforts in the country. Recommendations from this study would also have a broad applicability for communities and destinations elsewhere.

\subsection{Structure of the Thesis}

The remaining part of the thesis is organised into eight chapters as follows:

Chapter Two: This chapter reviews the concept of ecotourism and its context in Ghana. It underscores the general objectives and goals of ecotourism management, and presents an overview of the multiple definitions that is associated with the concept. The chapter also outlines the shortfalls of the concept with regard to the definition, as well as sustainability, and equity in stakeholder participation. The chapter further outlines and discusses some of the dimensions of ecotourism with respect to its impacts. It presents an overview of the environmental, socio-cultural, economic, and the experiential dimensions of ecotourism providing the background to assess what effects ecotourism activities could have on a given destination.

Chapter Three: Chapter three presents the conceptual framework on which the study is based, by establishing the relationships between local people and protected area; ecotourism activities and the protection of natural resources; the involvement of local people in ecotourism. It establishes the general methodological procedures that were employed in the data collection and the analysis. The chapters that deal with specific topics in relation to the study have individual sections that outline additional specific methodological procedures that were used.

Chapter Four: The chapter describes the protected areas of Ghana indicating their distribution, extent and years of establishment. It also describes the study area, outlining the flora and fauna as well as the general objectives pursued by the Wildlife Division of the Forestry commission with respect to managing the Kakum Conservation Area. The socio-economic conditions and livelihood activities of the local communities are also described. 
Chapter Five: This chapter considers the local communities' needs and interests in Kakum Conservation Area and its management. Among others, it examines local people's livelihoods, appreciations, perceptions and attitudes in order to identify options for participation in the area's management. The chapter also outlines the possible challenges that could arise participatory management of the conservation area.

Chapter Six: Chapter six focuses on visitors or tourists that patronise the Kakum Conservation Area. It analyses their characteristics, expectations and satisfaction with respect to recreational activities. The chapter looks at the motivation of tourists, their opinion on the tourism activities offered at the site and their preferences in order to make adequate recommendations for improvement in tourism service delivery and management in Kakum.

Chapter Seven: The chapter assesses the perceptions and attitudes of some households concerning ecotourism in selected local communities around the conservation area. The chapter looks at the perceived benefits of ecotourism development in the conservation area, the obstacles of participation and options for the creation of opportunities for local peoples' participation in tourism service delivery.

Chapter Eight: Chapter eight conflates the overall status of ecotourism in the Kakum Conservation Area based on the results that have been presented thus far, establishing the relationships: local people and Kakum; ecotourism and the protection of natural resources; ecotourism and local communities. It assesses to what extent management strategies have facilitated a harmonic relationship or not.

Chapter Nine: The ninth chapter identifies the Strengths, Weaknesses, Opportunities and Threats with regards to ecotourism development and protection of the conservation area. Subsequently, Threats $(\mathrm{T})$ and Opportunities $(\mathrm{O})$ in the external environment as well as internal Weaknesses (W) and Strengths (S) were analysed to propose strategic options to facilitate the further development and encourage adaptive management of ecotourism and conservation in the study area. Finally, the Analytic Hierarchy Processes is applied to the strategic options in order to guide the management authorities as to where they need to concentrate their efforts in improving their management strategies. Correspondingly, the chapter gives some general conclusions and recommendations for further development of ecotourism and the protection of natural resources in Kakum. 


\subsection{References}

Allen, L., Long, R., Perdue, R.R. and Kieselbach, S. 1988. The impact of tourism development on residents' perceptions of community life. Journal of Travel Research 27, 16-21.

Boo, E. 1990. Ecotourism: The Potentials and Pitfalls, World Wildlife Fund Washington, DC.

Ceballos-Lascurain, H. 1993. Ecotourism as a worldwide phenomenon. in K. Lindberg and D. E. Hawkins (eds). Ecotourism: a guide for planners and managers. The Ecotourism Society, North Bennington, Vermont. Pp. 312-315

Eagles, P. F. J., S. F. McCool, and C. Haynes. 2002. Sustainable tourism in protected areas: guidelines for planning and management. International Union for Conservation of Nature, World Tourism Organization. United Nations Environment Programme and Cardiff University, Gland, Switzerland.

Edelman, C. 2006. Ecotourism for Sustainable Development: Highlighting Setbacks of CommunityBased Ecotourism. (http://esys.ucsd.edu/internship/archive intern.profiles/papers/edelman paper.pdf)

Nature Conservation Research Centre. 2004. CBEP final report: Executive summary. Accra, Ghana: Nature Conservation Research Centre. 52 p (http://pdf.usaid.gov/pdf docs/PDACD818.pdf)

Nepal, S. K. 2000. Tourism, national parks and local communities. in R. Butler, and S. Boyd (eds.), Tourism and national parks: issues and implications. John Wiley \& Sons, London. Pp. 73-94

Ross, S. and Wall, G. 1999a. Ecotourism: towards congruence between theory and practice. Tourism Management 20:123-132.

Ross, S. and Wall, G. 1999b. Evaluating ecotourism: the case of North Sulawesi, Indonesia. Tourism Management 20:673-682.

Slinger, V. 2000. Ecotourism in the last indigenous Caribbean community. Annals of Tourism Research 27:520-523.

Stone, M. and Wall, G. 2003. Ecotourism and Community Development: Case Studies from Hainan, China. Environmental Management 33 (1): 12- 24. Springer-Verlag New York Inc.

Teye, V. 2000 Tourism Development Experience in Ghana. Development Policy Management Bulletin $7(1): 8-12$ 


\section{Chapter Two: The Conceptual Framework of Ecotourism}

\subsection{Ecotourism Context in Ghana}

Ghana is located in the West African sub-region, with a captivating mix of cultural, historical and natural heritage. The country has high potential and advantage for tourism development. It is home to ancient forts and castles which are relics that epitomise the European presence and the slave trade from the 1500s. These attractions draw numerous visitors from around the world, particularly from North America to Ghana. The country has emerged from a period of political instability between the 1970s to early 1980s as a result of military interventions (coups d'état) to a fledging example of democracy and rule of law in the sub-region since the early 1990s.

Since this period tourism has been targeted as a means to accelerate economic growth and infrastructure development in the country. It became a target for socio-economic growth by the government as a result of economic downturn and decreasing prices of the country's major export products on the world market. Consequently, tourism development has been on the upsurge, visitations gradually growing throughout the country, especially to the cultural centres, monuments and natural sites (including designated wildlife protected areas). This is as a result of the Ghanaian government identifying and promoting tourism as one of five areas for pursuing economic growth (Sirakaya, et. al., 2002; Teye, 2000). Tourism is thus seen as a means to reduce rural poverty rate and to enhance rural infrastructural development since the resources on which tourism depends are practically well distributed across the country and in rural areas.

In recent attempts to market Ghana as a "must visit" destination in West Africa, the catch phrase "Ghana Culture, Warmth and Much More" has been adopted to promote the country to attract a fair share of the tourist arrivals in the West-African sub region. The two main products to be developed for the leisure market are ecotourism, based on the country's diverse natural resource attractions, and heritage tourism based on cultural attractions related to the slave trade (Teye, 1999). Tourism development including ecotourism in protected areas of Ghana has grown rapidly making it the fourth highest foreign exchange earner in 2008 after gold, cocoa and remittances from Ghanaians resident abroad. This makes the tourism sector an important contributor to the economic development of Ghana. Currently, visitations to Ghana accounts for about $12 \%$ of the tourists share in West Africa. However, the target is to increase Ghana's share from $12 \%$ to $20 \%$ (one million visitors) by mid-2012 (Public-Private Partnership Forum in Tourism, 2009). Of these tourists, most take keen interest in visiting protected and natural areas. The obvious trend towards nature-based 
tourism and ecotourism is growing significantly, though Ghana has no clear strategic ecotourism development plans for implementation yet.

Ecotourism development in Ghana takes place mostly in the protected areas. The formal protected area system has been in existence in Ghana since the 1920s as a legacy of the British colonial administration which ended in 1957. According to Kotey, et. al. (1998), a large number of forest reservations in Ghana took place in the 1920s and 1930s. Nonetheless, some reserves were additionally created up until the end of the 1940s. These permanent forest estates were established by the colonial administrators with an intention to preserve climatic quality, protect watersheds and to ensure an environment which was conducive for cocoa production. Ghana is largely rural and agricultural based and therefore most of the inhabitants have purely depended on the land and the natural resource to support their subsistent livelihoods until recently. The creation of these protected areas meant then, that some of the rural poor were denied access to valuable resources that provided for their basic survival.

Over time, the protected areas, particularly under the jurisdiction of the Wildlife Division of the Forestry Commission of Ghana, have become an essential strategy for biodiversity conservation and for economic development of the country through ecotourism development. However, the poor rural residents, adjacent to these protected areas, who suffer both the impacts of tourism development and the denial of access to livelihood resources, have often been excluded from the planning and implementation by 'modern' dictates of natural (forest and wildlife) resources management.

Protected areas, according to Holdgate (1999 cited in Eagles, et. al., 2002) are a cultural artefact with long history. He stated that the idea of protecting special areas is universal: for example, it occurs among the traditions of communities in the Pacific ("tapu" areas) and in parts of Africa (as sacred groves). In Ghana, as noted by Kotey, et. al. (1998), traditional protected areas (such as sacred groves, burial groves and forests left at the headwaters or along the courses of rivers and streams), and the existence of forests in general, represent evidence that "forestry" and in particular forest conservation in Ghana, did not originate with the colonial administration and the establishment of a Forestry Department in 1909. The only difference perhaps was that, the management of these forests and protected areas were enshrined in the traditional arrangements of the local people and did not follow modern scientific methodologies. Many societies in early times set aside special areas for cultural and resource preservation purposes as in the case of Ghana. However, elsewhere, in 
Europe for example, protected areas were originally established by kings and other rulers as royal hunting reserves. But gradually these reserves became open for public use and provided the basis for community involvement and tourism (Eagles, et. al., 2002). Contrary, in most African countries, introduction of modern protected areas systems rather meant exclusion of communities from managing and using these areas. However, there is a gradual shift in trend and community involvement is becoming inevitable if the management of these areas shall be successful. Inadequate involvement of local communities poses tremendous challenge to protected area management in Ghana. Despite the restricted laws on illegal encroachment and resource extraction, poverty and lack of access to alternative resources drive local people to repeatedly enter the protected areas to extract resources and hunt wildlife, thus becoming competitors rather than collaborators to the ecotourism industry.

The government of Ghana through the Wildlife Division is promoting ecotourism in the Wildlife protected areas as a means to generate economic income and to facilitate local area development. Developing ecotourism is often seen as part of community-based natural resource management or decentralisation and for community empowerment (Rotha, et. al., 2005). Ecotourism development aims at improving natural resource management and conservation, while reducing poverty in rural poor communities on the grounds that local people are adequately involved. This practice is driven by growing social conflicts, rapid natural resources depletion, inadequate government funding for the management of protected areas, and the need for economic growth and poverty reduction among rural folks (Rotha, et. al., 2005).

While Ghana is a signatory to the convention on biological diversity (CBD) and is committed to the international conservation agenda, economic growth is increasingly getting important. One of the means to achieve this is through tourism development, particularly opening up its protected areas for ecotourism purposes. Currently, all the wildlife protected areas of the country are being promoted as ecotourism sites as a means to generate economic income from the resources. The government represented by the Wildlife Division of the Forestry Commission is paying more attention to the conservation of protected areas. This commitment is stimulating interest of concerned public institutions, civil society and the international conservation community to use ecotourism as a development tool in protected areas and other rural destinations of strong humannature relationship. By and large, within this framework, ecotourism has become a promising tool for promoting the objectives of protected areas in providing incentives to maintain ecosystem integrity and in sustaining the livelihood of local communities dependent upon natural resources. 


\subsection{Ecotourism as a Concept}

The concept of ecotourism is thought to have evolved as the conservation community, people living in and around protected areas and the travel industry witnessed a sudden increase in nature tourism and realised their mutual interest in directing its growth (Drumm and Moore, 2005). But Diamantis (1999) contends that the term emerged as a result of the general acknowledgement and reaction to sustainable use and global ecological practices. Others claim that the concept actually emerged simultaneously from conservationists in Latin America and Africa in the 1970s. Although they were invented for quite different reasons, they all boiled down to sound ecological practices.

In South or Latin America, scientists and environmentalists were concerned about the rapid destruction of the world's remaining tropical forests and viewed ecotourism as a potential alternative to the extractive industry. While in Africa, particularly in the East however, the concept evolved as an alternative to a failed protectionist philosophy of wildlife management based on separating the local people from protected areas and national parks - the 'fence and fine system'. Thus amid rampant poaching, park officials and some scientists began arguing that wildlife would survive only when the local people had a financial or beneficial stake in wildlife conservation. That notwithstanding, according to Orams (1995), the argument to actually incorporate conservation in tourism was first advanced by Budowski in his 1976 article entitled 'Tourism and Environmental Conservation: Conflict, Coexistence or Symbiosis.'

Budowski (1976) suggested that tourism may have one of three relationships with the environment: conflict, coexistence or symbiosis, but the latter, best describes all forms of nature based tourism, being a partnership between the two which is beneficial to both ends. However, Budowski further noted that in spite of the large potential for the symbiotic relationship, in most situations, the tourism industry has been in coexistence relationship tending towards conflict. He therefore concluded that utmost importance had to be placed on educational management strategies that promotes a symbiotic relationship (thus ecotourism) in order to avoid future conflicts between tourism and the natural environment (Budowski, 1976). Hence, the promotion of the concept is to avert conflicts in line with a growing interest in the natural environment and a corresponding recognition of the importance of conserving environmental quality. This can be understood as a result of the negative impacts being caused by mass tourism to natural areas. It should be emphasised, however, that people have long been travelling to natural areas for recreation and tourism. For this reason, some observers tend to question whether ecotourism is not simply a new name for an old activity (Wall, 1994). In cognisance of the increased awareness of environmental 
conservation and sustainability, several changes have apparently occurred. Growth of visitations to natural areas has increased particularly in the developing world. The demand of consumers for remote, natural and exotic environments has therefore created a rise in the ecotourism enterprises, especially in developing countries. Thus, although ecotourism in itself does not represent any abrupt departure from recreation and tourism, it still represents a change in the level of visitation in many areas and a change in the goals that various stakeholders attach to this visitation.

At first glance, ecotourism's potential market base seems to be small although the growth potential was reckoned to be large. As a result, developing countries saw ecotourism as an answer to develop their weak economies by capitalising on their natural tourism resources to earn foreign exchange without compromising sustainability (Cater, 1993). Consequently, many developing countries particularly in Sub-Sahara Africa have seen significant growth in their gross national product (GNP) ranging between $2.5 \%$ and $8.7 \%$ in mainland Sub-Sahara Africa (Christie and Crompton, 2001; see also The International Ecotourism Society (TIES), 2006).

The concept has been widely accepted and made popular due to the claims of potential benefits it offers. First, ecotourism can and is expected to generate funds for protected areas. Second, it can create employment for local people in surrounding communities, thus providing economic incentives to support protected areas. Third, it can advance environmental education for visitors. Fourth, it can provide justification for declaring areas as protected and for increasing support for these areas. Further, ecotourism programs aim to limit the negative impacts of nature tourists (Drumm and Moore, 2005). Nonetheless, these assumptions regarding the benefits of ecotourism have been challenged through empirical research (Lindberg, et. al., 1996). As a result, a more realistic understanding of what the product entails and the benefits it can provide is emerging.

In the beginning, many conservationists and tourism experts thought that the concept would give the answer concerning the threats to the development of conservation areas, including the threats of tourism development itself. It was also seen as a means to provide alternative benefits to the local community surrounding these areas. In fact, many of the claims concerning these benefits of ecotourism seem to have been exaggerated for the sake of marketing. As such, ecotourism projects are often planned and carried out without local consent and support, which in the end rather threaten than benefit local people's cultures, their subsistence economies and life-sustaining natural resource base. For this reason, some critics regard ecotourism as an "eco-facade" and as a tactic to conceal the consumptive and explorative practices of the mainstream tourism industry by "greening 
it" (Pleumaron, 1994; Munt, 1994). This is however not to say that ecotourism is not beneficial at all. When properly planned and implemented, ecotourism may indeed maximise benefits and limit the negative impacts of tourism flow in destination areas (Dei, 2008).

\subsection{Spectrum of Definitions}

Since its inception, the term ecotourism has been defined and explained in several different ways. Contrary to Drumm and Moore's (2005) assertion on the reasons why ecotourism has been widely accepted, Goodwin (1996) alleges that ecotourism has spread rapidly for two reasons. First, because it has a number of different meanings and second, because it has been extensively and opportunistically used in marketing, where the tag 'eco-' has come to be synonymous with responsible consumerism. Many authors (including Bottrill and Pearce, 1995; Buckley, 1994) also agree that much attention has been paid to the question of what constitutes ecotourism amidst the numerous conceptual definitions that exist. Hence, considering Fennel's (2001) analysis of 85 ecotourism definitions, it could conveniently be stated that ecotourism is one of such terms or concepts that have been around for several decades and yet nobody has been able to give a precise definition of what it is. Ziffer (1989) points out clearly that the term has eluded a firm definition because it is a 'complex notion which ambitiously attempts to describe an activity, set forth a philosophy and espouse a model of development.'

Clearly, there is no standard definitional nomenclature in the field of ecotourism. Therefore many of the literature fail to differentiate between nature-based mass tourism and ecotourism which is small and limited. A review by Buckley (1994) describes four types of travel that are commonly given the ecotourism label: (1) nature-based tourism; (2) conservation-supporting tourism; (3) environmentally aware tourism; and (4) sustainability-run tourism. Further, the term ecotourism is often used interchangeably with sustainable tourism. However, Weaver (2001) contends that this is erroneous because ecotourism is a subset of sustainable tourism given that sustainability is one of the main criteria for ecotourism. It is therefore not surprising that there is considerable debate about the normative (what it should be) and positive (what it is) definitions of ecotourism (Orams, 1995). Again, other studies like Orams (2001) and Donohoe and Needham (2006) also acknowledge that many definitions and types of ecotourism exist but, in its broadest sense, ecotourism principally concerns travel to a natural area; involving local people; providing financial support for local environmental protection; and as well contributing to the maintenance of the local environment and species diversity through minimising visitor impacts and promoting tourist education (Diamantis, 1999; 
Fennell, 2001). In addition, it enhances local people's education through appreciation of the inherent value of natural resources within their surroundings. Similarly, Sirakaya, et. al. (1999), who performed a content analysis on 25 of the most widely accepted ecotourism definitions, noted that ecotourism is operationally characterised as a form of tourism activity and development that produces: i) a minimal negative impact on the host environment; ii) an evolving commitment to environmental protection and conservation of resources; iii) financial resources to support and sustain ecological and socio-cultural resources; iv) an active involvement and cooperation of local residents as well as tourists in enhancing the environment; and v) economic and social benefits to local or host community.

In spite of the preceding characteristics, most of the conceptual definitions of ecotourism can be reduced to the following: ecotourism is tourism and recreation that takes place in natural areas and is sustainable (Fennel, 2001; Diamantis, 1999). This simplified definition suggests three features. One, the definition elucidates the descriptive and the prescriptive components of ecotourism as a concept. The 'descriptive' (or positive) component simply describes the location of the activity, that is nature-based, and the associated motivation of the visitors. The 'prescriptive' (or normative) component in this sense reflects what people want the activity to be: sustainable. Sustainability, as used here, incorporates the environmental, socio-cultural, experiential, and economic dimensions of the ecotourism concept. This basic conceptual definition incorporates more complex definitions. For example, borrowing from Fennel's (2001) content analysis, some of the definitions seek to focus on minimising the negative environmental and cultural impacts while maximising the positive economic impacts. Such a focus is a means to achieving sustainability as propounded by the concept. By focusing on the end result (the desire to achieve sustainability), the definition invariably forces a critical evaluation of what actually constitutes ecotourism.

Blamey (1997) asserts that the existing definitions of ecotourism are multi-dimensional in nature and each of the dimensions offer a continuum of possibilities. These factors therefore make it difficult to reach a consensus on a single definition. The consequence of so many multi-dimensional definitions is translated in the inability to instil meaning and standards in the ecotourism industry (Fennel, 2001). According to Cater (1994), the term is shrouded in ambiguity. The ambiguity has made it possible for manipulations that serve political and business interests. The deliberate misrepresentation of the term is therefore believed to have led to cynicism which is negatively affecting the reputation of some genuine ecotourism products (Weaver, 2001). 
Further, the idea that ecotourism is a continuum or spectrum (Orams, 1995), comes along with varied implications for the implementation of the concept. The spectrum is bounded by polar extremes where all the variable paradigms fall within. Thus, the variability in the conceptual definitions makes it difficult to move from a conceptual definition to an operational definition. Hence, Blamey (1997) noted that any attempt to establish an operational definition cannot be devoid of subjective decisions. Meaning different definitions will be suited to different circumstances as it has been the case since the inception of the term.

Back to the idea of continuum, Orams (1995) also pointed out that ecotourism definitions can be classified in accordance with the tendency for a low- or high-level of human responsibility. Orams explained that all definitions tending to suggest that ecotourism should contribute to improvement of the natural environment would lie toward the high human responsibility pole on the spectrum. By this explanation, the definition of Ceballos-Lascurain who is widely acclaimed as the first to explicitly use the term ecotourism (Boo, 1990 cited in Weaver, 2001; Diamatis, 1999), lies towards the low human responsibility pole and therefore classified as passive. Ceballos-Lascurain (1987, cited in Sirakaya, et. al., 1999) defined it as - "travelling to relatively undisturbed or uncontaminated areas with the specific objective of studying, admiring and enjoying the scenery and its wild plants and animals, as well as any existing cultural manifestations (both past and present) found in these areas."

On the other hand, though many definitions tend to be general in nature and fall closer to the central or passive positions on the continuum, the definition of the International Ecotourism Society "purposeful travel to natural areas to understand the culture and natural history of the environment, taking care not to alter the integrity of the ecosystem, while producing economic opportunities that make the conservation of natural resources beneficial to local people (Wood, 1991 cited in Goodwin, 1996)", - takes an active and responsible role, at the high human responsibility pole, and contributes to maintaining the quality of the natural environment. It suggests that, ecotourism is based on the sustained conservation of resources in a non-consumptive manner involving non-intrusive exploitation of natural resources through the controlled use and management of cultural and environmental resources. For ecotourism to be beneficial, its management should seek to lean towards the active high human responsibility pole to minimise negative impacts on the environment. The following explanations and definitions of ecotourism are presented in Table 2.1 to underscore the existence of competing descriptions and explanations of the concept. Such a plethora of explanations or definitions certainly would also make it difficult to design a specific standard of assessment for the concept. 
Table 2.1 Concept and Definitions of Ecotourism

\begin{tabular}{|c|c|}
\hline Study & Description or Definition of the Concept \\
\hline $\begin{array}{l}\text { Ceballos-Lascurain } \\
\text { (1987) }\end{array}$ & $\begin{array}{l}\text { Travelling to relatively undisturbed areas or uncontaminated natural areas with } \\
\text { the specific objective of studying, admiring, and enjoying the scenery and its wild } \\
\text { plants and animals, as well as any existing cultural manifestations (both past and } \\
\text { present) found in these areas. }\end{array}$ \\
\hline Butler (1989) & $\begin{array}{l}\text { Ecotourism is a type of tourism that attempts to give travellers a greater } \\
\text { awareness of environmental systems and contribute positively to the } \\
\text { destination's economic, social and ecological conditions. }\end{array}$ \\
\hline $\begin{array}{l}\text { Fennell and Eagles } \\
\text { (1989) }\end{array}$ & $\begin{array}{l}\text { Ecotourism or nature-oriented travel is a viable means to stimulate economy and } \\
\text { at the same time to establish and maintain a system of protected areas . . } \\
\text { characterized by a primary desire to study specific elements of nature in } \\
\text { sensitive environments ... fulfilled by activities such as bird watching, whale } \\
\text { viewing and wild-flower photography. }\end{array}$ \\
\hline Kutay (1989) & $\begin{array}{l}\text { Ecotourism is a model of development in which natural areas are planned as } \\
\text { part of the tourism base and biological resources are clearly linked to the social } \\
\text { and economic sectors. }\end{array}$ \\
\hline Ziffer (1989) & $\begin{array}{l}\text { A form of tourism inspired primarily by the natural history of an area, including its } \\
\text { indigenous cultures. It involves visits to relatively undeveloped areas in the spirit } \\
\text { of appreciation, participation, and sensitivity. Ecotourism also implies a managed } \\
\text { approach by the host country or region which commits itself to establishing and } \\
\text { maintaining the sites with the participation of local residents, marketing them } \\
\text { appropriately, enforcing regulations, and using the proceeds of the enterprise to } \\
\text { fund the area's land management as well as community development. }\end{array}$ \\
\hline Ziolkowski (1990) & $\begin{array}{l}\text { Low-impact tourism which focuses on experiencing the local culture and what it } \\
\text { has to offer on its own unadulterated terms ... far from the proverbial "beaten } \\
\text { track." }\end{array}$ \\
\hline Boo (1991) & $\begin{array}{l}\text { Ecotourism / nature-oriented tourism refer to tourism to relatively undisturbed } \\
\text { natural areas with the specific objective of admiring, studying and enjoying the } \\
\text { scenery and its flora and fauna. }\end{array}$ \\
\hline $\begin{array}{l}\text { Farrell and Runya } \\
(1991)\end{array}$ & $\begin{array}{l}\text { a subset of nature tourism taken a step farther, with nature and tourism } \\
\text { considered equal partners, exclusively purposeful and focused on the } \\
\text { enhancement or maintenance of natural systems through tourism. }\end{array}$ \\
\hline Williams (1992) & $\begin{array}{l}\text { Ecotourism entails "travel with substance" [and involves] travelling in relatively } \\
\text { primitive and rural circumstances, rustic accommodations, muddy trails, basic } \\
\text { amenities, the pay-off being a stronger appreciation and closer contact with } \\
\text { wildlife, local culture and resource conservation issues. }\end{array}$ \\
\hline Brause (1992) & $\begin{array}{l}\text { Ecotourism suggests travel opportunities designed to help people get more in } \\
\text { touch with the beauty, wonder, and value of the environment and then to do } \\
\text { something to preserve, protect, or restore what has been destroyed or nearly } \\
\text { destroyed by our recent (and, in some cases, distant) ancestors. }\end{array}$ \\
\hline Western (1993) & $\begin{array}{l}\text { Ecotourism is really an amalgam of interests arising out of environmental, } \\
\text { economic and social concerns which incorporates both a strong commitment to } \\
\text { nature and a sense of social responsibility. . . extends to the sensitivity of the } \\
\text { travellers. }\end{array}$ \\
\hline Agardy (1993) & $\begin{array}{l}\text { Viewing wildlife (such as birds, sea turtles, and marine mammals), learning } \\
\text { about coastal ecology (especially wetlands ecology), SCUBA diving or } \\
\text { snorkelling in undisturbed areas, or to experience nature in its broadest sense. }\end{array}$ \\
\hline Miller (1993) & $\begin{array}{l}\text { Ecotourism has international currency as a concept grounded in preservation- } \\
\text { conservation and sustainable development ideals. As the term has come to be } \\
\text { employed, it evokes a host of near synonyms . . . "equality tourism," "ethnic } \\
\text { tourism," "cultural tourism," "socio-ecological tourism," "photo-safari tourism," } \\
\text { "drive tourism," and "surfing tourism." }\end{array}$ \\
\hline Valentine (1993) & $\begin{array}{l}\text { New form of tourism . . . especially concerned with the appreciation of nature as } \\
\text { the primary motive to participate, but with an essential element of zero negative }\end{array}$ \\
\hline
\end{tabular}




\begin{tabular}{|c|c|}
\hline & $\begin{array}{l}\text { impacts ... based on relatively undisturbed natural areas, non-damaging, non- } \\
\text { degrading, ecologically sustainable, a direct contributor to the continued } \\
\text { protection and management of the natural areas used, subject to an adequate } \\
\text { and appropriate management regime. }\end{array}$ \\
\hline Wallace (1993) & $\begin{array}{l}\text { Providing assistance such as interpretation, resource inventory and monitoring, } \\
\text { and visitor concession management-working effectively with local people who } \\
\text { live in or near wild lands and cooperating with non-profits-everyone will benefit } \\
\text { from viewing wilderness in the global context. }\end{array}$ \\
\hline Wight (1993) & $\begin{array}{l}\text { An enlightening nature travel experience that contributes to conservation of the } \\
\text { ecosystem, while respecting the integrity of host communities. }\end{array}$ \\
\hline Andersen (1994) & $\begin{array}{l}\text { Ecotourism is a tourism experience infused with the spirit of conservation and } \\
\text { cultural change that results in a net positive effect for the environment and local } \\
\text { economy . . . may be part of an overall economic and environmental plan that } \\
\text { includes sustainable agriculture, micro-industries and other activities . . . } \\
\text { minimise the human intrusion on the ecosystem, to educate travellers and to } \\
\text { enhance the spiritual experience in nature that fosters respect and stewardship. }\end{array}$ \\
\hline Buckley (1994) & $\begin{array}{l}\text { Integration of nature based products and markets, sustainable management to } \\
\text { minimise impacts, financial support for conservation, and environmental attitudes } \\
\text { and education of individual people. }\end{array}$ \\
\hline Wall (1994) & $\begin{array}{l}\text { Ecotourism refer to tourism which takes place in relatively natural settings or } \\
\text { directed at specific components of such settings including rare or endangered } \\
\text { species of plants or animals. These locations are often at considerable distance } \\
\text { from the areas of demand, the former often being in countries of the South } \\
\text { whereas the ecotourists usually originate in the North. }\end{array}$ \\
\hline Place (1995) & $\begin{array}{l}\text { Ecotourism represents a response to phenomena occurring in both centre and } \\
\text { periphery, deriving from the dominant global economic paradigm based on } \\
\text { continuous growth . . . in the centre, industrial and urban development caused } \\
\text { destruction of natural ecosystems and degradation of the environment in general } \\
\ldots \text { in the periphery, stagnant or declining commodity prices and growing foreign } \\
\text { debts forced governments to seek economic alternatives. }\end{array}$ \\
\hline $\begin{array}{l}\text { Kinnaird and O'Brien } \\
\text { (1996) }\end{array}$ & $\begin{array}{l}\text { Ecotourism or nature tourism is implicitly assumed to have little or no impact on } \\
\text { the environment ... . appears to be an ideal solution for combining goals of } \\
\text { development and conservation. }\end{array}$ \\
\hline
\end{tabular}

Source: adapted from Sirakaya, et. al. (1999).

Fennell's (2001) content analysis revealed some trends in ecotourism definitions over a 15 year period. He showed that definitions of ecotourism have evolved from emphasis on nature-oriented tourism to one which stresses both natural and cultural goals. Example, benefits to local communities became prominent in definitions that emerged between 1997 and 1999 compared to earlier definitions. Further, reference to sustainability and impacts were strongly emphasised within the 1994 and 1996 period and after. But what does all this numerous definitions and emphasis mean? In Fennel's opinion, the influx of these numerous definitions point to the fact that 'we have either not got the concept right, or that there ought to be different rules for different geographical regions.' 


\subsection{General Objective of Ecotourism Management}

One could conclude after a review of the existing plethora of definitions, that the key objective of ecotourism management is attracting ecotourists/visitors to natural areas and using the revenue accrued to fund local conservation initiatives while giving the impetus for local area economic development. However, the overall goal of ecotourism management seeks to control the interaction between ecotourists and the natural environment (Orams, 1995). Whichever management strategy is pursued, it is important to emphasise on sustainability of the ecotourism programme since all the conceptual definitions of ecotourism are inherently implying sustainability.

In plain terms, sustainability of ecotourism is presupposed to result from a positive overall balance in the dimensional impacts of ecotourism. These dimensions include: environmental, experiential, socio-cultural, and economic dimensions as alluded to earlier. The positive overall balance is in reference to net benefits accrued as a result of ecotourism activities. Thus, ecotourism activities that generate more positive net benefits would be more sustainable, in general, as compared to ecotourism activities that generate fewer positive net benefits in the above mentioned dimensions. The focus on benefits also elucidates the objectives of ecotourism. In general, in order to increase revenue, many sites managers seek to increase the number of visitors, but this objective could have adverse consequences and therefore is slowly giving way to rather increase visitor expenditure at the destination (a positive benefit). Ultimately, the objective should be to increase net benefits to destination area conservation and to resident local people. An objective of ecotourism management that is focused on increasing net benefits will thus enhance the likelihood that ecotourism will be sustainable. Therefore in recognition of the importance of the sustainability of ecotourism and the expectation to facilitate conservation initiatives in destination areas, ecotourism programmes are thus expected to:

i. ensure low-impact visitor activity and non-disruptive to the protected area and as well as wildlife (flora and fauna);

ii. support and finance conservation of ecosystems at local level or destination area;

iii. be sensitive towards local people and avoid undesirable socio-cultural changes;

iv. create opportunities that offer sustainable benefits to local people living adjacent to the destination area;

v. facilitate development in surrounding rural communities;

vi. ensure local people's participation in decision-making on both conservation and ecotourism development; 
vii. create awareness of nature conservation and environmental issues for both ecotourists and local communities;

viii. bring satisfaction to both ecotourists and local people;

ix. build an enabling environment (institutional framework/policy) for ecotourism development and promotions (Diamatis, 1999; Stecker, et. al., 1996; Weaver and Lawton, 2007).

\subsection{Stakeholders in Ecotourism}

Ecotourism by its nature suggests that it is a multi-disciplinary and multi-sector endeavour and therefore its successful development would require collaborative arrangement among relevant stakeholders. Thus, these entities need to be fully involved in the process from planning through the developmental stages and finally management for sustainability. Though ecotourism often involves numerous actors/stakeholders, the relevant actors will vary across sites. For example, local communities may be present at some destination areas, but not in others. Likewise, travel and tourism businesses may play a large role at some sites, while they may have little or no role to play at others. The key stakeholders in ecotourism considered in this study include: visitors/ tourists, natural/ protected area managers, local people/ communities, government and non-governmental organisations.

Visitors/Tourists - the visitor/tourist is an essential actor whose action or inaction affects the overall activities of every other actor. The choices that visitors make from organising their trip to ultimately participating in a particular activity have tremendous impact on the eventual success or failure of any ecotourism programme. Hence, their satisfaction is vital to the sustainability of ecotourism in any destination;

Natural/Protected Area Managers - Protected area managers have a daunting challenge to maintain a balance between the ultimate objectives of nature or biodiversity conservation and interests of other stakeholders in ecotourism. Generally, protected area managers are professionals in the fields as botanists, wildlife specialists or biologists who primarily conduct inventories and ensure scientific management of wildlife populations but maintain visitor facilities at the destination as well.

However, for ecotourism to be effective, these managers need to be able to work closely with the other actors in ecotourism. They hold the centre of all activities. Their actions must therefore be 
directed at guiding the conflicting interests of all the other actors in ecotourism in order to maximise benefits for the protected area and conservation goals;

Local People/Communities - these constitute people living in and adjacent to natural or protected areas. It is acknowledged that local people are not homogeneous. They have different needs and views and therefore their interests are pertinent to ecotourism development. In many cases, local people and communities have to deal with the impacts of ecotourism without any choice; whereas all other stakeholders in ecotourism have the option of voluntary involvement. Again, ecotourism touches the personal lives of local people by affecting their lifestyle, traditions and culture, as well as their livelihood and their long standing ways of organising themselves socio-politically within the communities. Nevertheless, their relationship to and uses of natural resources invariably determines the success of conservation initiatives for the protected areas on which ecotourism depend. Therefore it is important to actively involve local people in the development process and as well make them active decision makers in the management;

Government - Although most ecotourism activities happen at the local level, they need to fit into systems designated at the national level. Government officials including protected area managers (often government employees) have several significant functions in the development and management of ecotourism in order to make it fit the national agenda. They provide leadership, coordinate and articulate national goals for ecotourism.

Government officials set up adequate policy environment by establishing specific policies for protected areas and ecotourism development. For example, they decide on visitor use fee mechanisms at protected areas, or Governments may impose taxes and through their policies outline how revenues will be disbursed or distributed. Including allocating a portion of the revenues to protected area management (e.g. by directing appropriated funds, or establishing an endowment and using the interest for management) as explained by Eagles, et. al., (2002). Further, they set the stage for active participation of all key stakeholders in ecotourism. A common phenomenon is that ecotourism can generate both symbiotic and conflict relationship between the actors. Hence, government policies are generally expected to direct ecotourism activities and may easily enhance or hinder their growth. Beyond these functions, government officials are also responsible for many of the structures and services outside the protected area which greatly affect ecotourism at specific sites or destinations. The government, through its officials also plays the unique role of ensuring resource protection. Security of the environment and public safety is an overarching government responsibility. In most cases, basic tourism infrastructure is paid for by the public purse. 
Non-Governmental Organisations (NGO) - Non-governmental organizations are important partners because they provide a platform for discussion and can influence the process of developing ecotourism at the local level. They are usually involved either to ensure the protection of biodiversity or to facilitate sustainable development for the local people. Compared to public institutions, NGOs are generally perceived as more efficient actors in service delivery and thus have been promoted as intermediaries in development processes (Forstner, 2004). These organisations can therefore serve as vehicles for bringing together all the elements of ecotourism. NGOs can play many different roles in ecotourism implementation: directly, as programme managers or site administrators; and indirectly, as trainers, advisors, business partners with ecotourism companies or communities and, in exceptional circumstances, as providers of ecotourism services. Their focus may be local, national or international. They offer a means of communication with huge numbers of interested individuals. Frequently, these organizations serve as facilitators between protected areas, communities and all the other players in ecotourism, sometimes providing financial and technical assistance or directly managing ecotourism sites. Some of these NGOs have constituencies that enjoy nature and would be interested in ecotourism education and promotion. These organizations can therefore provide adequate information and guidance on ecotourism issues, so they can influence the consumers of ecotourism, the ecotourists.

In the specific case of Kakum Conservation Area, two NGO are worth to be mentioned for their contributions to the conservation area. They are the Ghana heritage Conservation Trust (GHCT) and Conservation International $(\mathrm{Cl})$. At the initial stages of forming the Kakum Conservation Area, $\mathrm{Cl}$ advocated for a greater concentration on community development as part of the conservation programmes. But this could not be carried through as a major component even though it was an attempt to increase community involvement or participation and benefit sharing. Nevertheless, $\mathrm{Cl}$ managed to start up a few income-generation projects in several communities around the conservation area. The projects included snail-farming, bee-keeping, and grasscutter-rearing. However, during the study tour, none of the communities visited still had the projects running. Apparently, they collapsed after the project funding and the support stopped, indicating that they could not achieve operational independence although they were designed to facilitate the achievement of conservation objectives in the area.

The GHCT was formed to ensure the sustainability of the conservation programme and therefore took over the management from $\mathrm{Cl}$. The GHCT initiated the Community Tour Guide programme which they implemented in collaboration with the Wildlife Division. They also started the rehabilitation of a few schools in some communities, developed some field camps in the 
conservation area and are responsible for the maintenance of facilities at the visitor centre as well as the canopy walkway. The GHCT holds the mandate to ensure that local communities participate and benefit from the conservation and ecotourism programme. However, the organisation has not been able to achieve that after forming the Community Tour Guides to make benefit sharing become widespread in the communities.

\section{Tourism Businesses (Tourism agencies and Tour operators)}

Typically, the private sector provides most of the services and consumer products in tourism. The private tourism operators provide accommodation, food, transport, and facilitate site promotion and advertisements. Tourism businesses and operators have the ability to respond quickly to consumer demands and to develop specialised products (Eagles, et. al., 2002).

Through their activities and operations, tourism agencies and operators provide jobs for local people and facilitate infrastructure development within the destination areas, while enhancing the tourism experience. However, it is worth noting that though the private sector operators can respond quickly to new consumer desires for recreation or tourism services, they are not able to align quickly to changes in fees that they are charged by agencies or governments. The commercial tourism sector generally sells tours well in advance and cannot accommodate sudden fee changes (Eagles, et. al., 2002). This can be detrimental to the sustainability of their operations and therefore requires appropriate training and the knowhow to run successful tourism business.

\subsection{Shortfalls of Ecotourism as a Concept}

There is some amount of uncertainty about the effectiveness of using ecotourism as a means to achieve sustainable natural resource conservation and community development. This is largely so because the level of success or impacts of ecotourism depends on many influencing inextricably interwoven factors (King and Stewart, 1996). This subsection points out some of the shortcomings of the ecotourism concept which hinder successful implementation to bring about profound changes necessary to work towards sustainable development. The following gives short account of the implications of the plethora of conceptual definitions, sustainability, equal partnership among the key stakeholders, as well as the use of ecotourism as a development tool. 


\subsubsection{Definitional Dilemma of Ecotourism}

As reviewed in section 2.2, ecotourism has been widely promoted as a viable alternative to environmentally and socio-culturally degrading conventional tourism and the extractive industries, as a form of sustainable development, which can yield immediate economic returns without posing major risks of damage to the natural environment and the local communities. However, there is no consensus on its definition thus making the whole concept somewhat ambiguous. Consequently, a common understanding of its meaning does not exist, leaving the option for multiple interpretation and possible misrepresentation by some actors including national governments (see Fennel, 2001; Weaver and Lawton, 2007).

The definitional challenge of ecotourism therefore gives ample room for "green labelling" of some existing conventional tourism activities, thus fudging existing activities as if they fitted into the sustainable development concept. This assertion is supported by Goodwin (1996) who stated that 'the tourism industry has been quick to exploit the marketing value of ecotourism, the more so since its meaning is unclear and there is no requirement for the operator to do more than just alter the packaging.' This gives the opportunity to other actors to accrue all the benefits at the detriment of local resident people who might have no choice but to absorb the costs of ecotourism operations within their locality.

\subsubsection{Sustainability of Ecotourism}

The 1987 Brundtland Report "Our Common Future" and the 1992 United Nations Conference on Environment and Development (UNCED) seem to have inspired ecotourism policies based on their attempts at delineating development through "sustainability".

However, the definition of sustainability and what it seeks to achieve remains an important challenge in the sustainable tourism literature (Hunter, 2002). The definitions and meanings of sustainability are paramount in any tourism policy that looks to the future. Hence, McCool, et. al. (2001) explained further that sustainability can be viewed as an appropriate goal in an era of change and uncertainty.

The World Commission on Environment and Development (1987) provided the definition of sustainability as: "development that meets the needs of the present without compromising the ability of future generations to meet their own needs". This means whatever development activity the current generation undertakes, it should leave the same natural capital for the future generations. So in essence, sustainability is associated with environmental protection. Farrell (1999) thus described the core tenet of sustainability as an attempt to integrate economy, society and environment or 
create a 'sustainability trinity'. This suggests that sustainability has multiple objectives which include: i) redistribution of income, ii) intergenerational and intra-generational equity, iii) maintenance of ecosystems, iv) maintenance of life options, v) maintenance of resilient human-natural systems and vi) redistribution of power.

Nonetheless, Harrison (1996) hinted that sustainability - and especially sustainable tourism including ecotourism - is a problematic concept when applied to socio-cultural phenomena which ecotourism in any form has the potential to influence. The point is that, it is difficult to distinguish between social and cultural attributes that are functional and dysfunctional for the continuance of a social system and how these feature in a social system that is part of the wider natural environment. There are no clear criteria for determining which of the socio-cultural changes pose an outright threat to a society's distinctiveness as a result of tourism in this case ecotourism. Harrison further stated that "current differences in the assessment of the merits of social change in tourist-receiving societies are based more on differences in ideology and moral positions than on sound social analysis, the tools for which simply do not exist" (Harrison, 1996). Meaning it will be difficult to guarantee the maintenance of the status quo in any given society when faced with external shocks from touristic influences.

Further, ecotourism can present a risk to the ecological sustainability of the destination areas. Thus, there is a high possibility that ecotourists (however well intentioned) might disturb and alter the feeding and breeding patterns of wildlife (fauna), involuntarily transmit diseases and modify habitats, just by their mere presence in some environmentally sensitive areas. On these accounts, ecotourism's role in sustainability of the socio-cultural fabric of society and environmental integrity has to be questioned. However, in cognisance of the fact that there is no full proof in any system, the concentration should be directed on how to tilt the balance towards net benefits to ensure that conservation objectives are achieved.

\subsubsection{Equal Partnership among Stakeholders}

There is a wide range of actors with varying interests and goals participating in ecotourism as indicated in subsection 2.5. Although the concept and practice of ecotourism brings together these different actors, the relations among governments, conservationists, communities and tourism practitioners have not always been smooth and collaborative. A key to the success of ecotourism is therefore the formation of strong partnerships among the actors, with a set of agreed common agenda, so that the multiple goals of conservation and equitable development can be met. 
Ecotourism is sometimes viewed as an alternative occupation for local people on the assumption that local practices are threatening to biodiversity conservation. Therefore there is the need to provide local people with alternative sources of income that do not threaten to deplete the natural resources (Brandon, 1997). However, ecotourism projects are often implemented in a top-down approach, with little consideration for the social and cultural relevance of certain local practices (Neumann, 1997; Michaelidou, et. al., 2002). Furthermore, in some cases, if not all, the economic growth of the state and the environmental governance remain a top priorities of governments which prevail the strengthening of the social fabric and the improvement of wellbeing of local communities (Abbot and Thomas, 2001; Kiss, 2004). This often creates strained relations between government agencies and local communities with negative repercussions particularly on conservation initiatives.

The assumption that poor communities lack conservation ethics and are responsible for the loss of biodiversity is mostly directed towards less developed countries (Michaelidou and Decker, 2003). Many measures are directed at criminalising on one hand and seeking to change the supposed destructive way of life of local people. However, such imposing attitudes only help to create antagonism between conservation institutions and local communities but fail to create the ground for true partnership and collaboration.

A major assumption underlying the ecotourism concept is that cooperation between the tourism industry, governments, NGOs and local communities will translate into successful planning and implementation of ecotourism. This view must also be revisited because it does not take into account the divergent interests and motives of the various participants in ecotourism. In reality, all forms of tourism development tend to follow the narrow economic interests, which usually counteract cultural and ecological sensitivities of local communities. Hence, the governmental planning and management tend to be centralised without adequate involvement of local people or communities which are perceived as culprits and less powerful actors. This does not ensure equity in roles and responsibilities nor in cost-benefit sharing among actors. From this perspective, it is argued that discussions on conflict management and trade-offs between environmental and developmental goals will hardly, if ever, result in more equity and justice especially in ecotourism where most local communities are blatantly side-lined in the planning, development and management process (Cater, 1995). 


\subsubsection{Ecotourism as a Development Tool}

Against all reservations that have been mentioned so far, the conservation community has adopted the ecotourism concept as a means to partake in the sustainable development discourse, which justifies conservation regimes in the face of development needs (Ziffer, 1989; Honey, 1999, Swarbrooke, 1999; Campbell, 2000). The adoption is due to recognitions that the tourism industry, to which ecotourism belongs, is a powerful economic system, which is commercially driven and increasingly impacting on the ecosystems of the world's protected areas. Given the expectations of growth in this sector, increasing numbers of protected areas will experience rising numbers of tourists (Goodwin, 1996). Consequently, policy makers and developers regard ecotourism as a reliable means which comprises pro-poor tourism concepts in rural nature-based areas. This is because it places importance on both the protection of local natural ecosystem and sustainable livelihood approach. Resent research does suggest that there is the potential to apply tourism development to natural areas to stimulate income opportunities for the poor communities.

The contribution of ecotourism to the sustainable development of local communities is obvious as soon as it provides direct, indirect and induced socio-economic and cultural benefits, without compromising important bases of their places such as natural resources (Ross and Wall, 1999; Weaver, 2002) or ecosystem services. Besides acting as a guard to protect and revitalise local cultures (Ferrell and Runyan, 1991), ecotourism is touted to provide other advantages to the communities. These include job creation, generation of revenue for community economic development, improvement of community participation and empowerment, diversification of local economy, increase in natural and cultural appreciation among the locals and other multiplier effects (Sirakaya, et. al., 1999; Weaver, 2002; Jenkins and Wearing, 2003). Most of the highly sort after touristic destinations in less developed countries are typically located in rural or peripheral regions (Hall, 2005). These destinations are scaling on the basis of national parks, wilderness zones, mountain areas, cultural sites, and other protected areas and biosphere reserves which inhabit rich ecosystem and biodiversity (Campbell, 1999; Holland, et. al., 2003). Hall (2005) noted that rural economies are exposed to global influences, which are economically, socio-culturally and environmentally different and that their inhabitants are becoming stronger in larger regional centres. In this respect, Hall argues that developments in both local and global economics bring changes to rural areas, and tourism is becoming a fundamental approach to help rural areas adapt to these changes. For this reason, there is widespread optimism that tourism can be potentially developed as a key sector to help recuperate rural economies that have the requisite resources. Poor rural areas are often characterised by ecotourism potential which provides good opportunity for economic 
development in the long-run. Ecotourism has thus been regarded as a tool that spreads out benefits to rural areas, while at the same time triggers positive impacts on poverty reduction and environmental or natural resource conservation.

Generally, ecotourism is said to offer close relation to the concept of sustainable community development, because it is small scale by nature and has less impact on both human society and the natural environment than nature based tourism (Brandon, 1996). The benefits of ecotourism are seen in its contribution to conservation and development. With sound mechanisms, it could build positive bond that provides synergistic effects between tourism, community development and resources management and protection (Ross and Wall, 1999a; 1999b). However, based on their modernist and populist attitudes, development and conservation organisations often use their politics, operational agendas and presumptions to identify and prescribe what local communities would need and should do, and what should best tackle the existing problems (Reed, 1997; Berkes, 2004). This is because ecotourism protagonists claim that subsistence economies are not productive, they are unprofitable, while local people are at the same time ignorant of and responsible for the environmental degradation caused by their subsistence practices.

On the other hand, there is hardly any recognition of the fact that indigenous non-dominant, ecologically sound economic systems prevail in some places. Consequently, many developing nations have showed strong political commitment to apply ecotourism as a new integrated approach for rural development, poverty alleviation and sustainable development. Their ecotourism policies often involve the expulsion of the people who in fact have contributed to shape the biodiversity-rich landscapes and complex plant and wildlife habitats over generations. Such dysfunctional experiences are well documented (Koch, 1994; Mclvor, 1994; Peluso, 1993). In relation to third world countries, crucial questions regarding the international political economy and the widening gap between North and South are being sidestepped. Debt-ridden, in need of foreign exchange, and increasingly tied to the global economy, many third world governments see little option but to exploit their natural resources for tourist consumption. Meanwhile the global drive for biodiversity protection has enabled transnational corporations and organisations which are dominated by industrialised countries to increasingly intervene in the affairs of these third world countries and reap from their huge investments in ecotourism ventures sometimes at the expense of these poor countries. 


\subsection{Multidimensional Impacts of Ecotourism}

In line with the main research topic, the following section attempts to briefly dilate on the dimensions of ecotourism in order to give a foundation and an impetus to the analysis and discussions that ensues from the realities of ecotourism activities within the Kakum Conservation Area. Again, it offers the overall picture of what general effects ecotourism would have on any given destination, taking into account the wide range of definitions. The dimensions to be included in this section are: environmental, experiential, socio-cultural and economic dimensions.

\subsubsection{The Environmental Dimension}

The environmental dimension of ecotourism emphasises the need to reduce pressure on the physical environment. Consequently, most discussions on this dimension focus on the negative impacts. This emphasis disguises the main environmental benefits of ecotourism which are the potential incentive value in conserving natural resources (Weaver, 2002). Ecotourism can and does generate positive environmental impacts. Also, ecotourism can generate indirect positive impacts by increasing political and economic support for natural area conservation and management (Lindberg, et. al., 1996). In addition, it offers opportunity for both ecotourists and local people to learn and exchange values of environment and the associated uses. Some tourists even volunteer to undertake cleaning of hiking trails or rehabilitation work at the destination area. According to Orams (1995), ecotourism management can facilitate positive attitude and behavioural change in both ecotourists and local people to enhance conservation of natural resources within and outside protected areas or destination sites.

The descriptive component of ecotourism by definition involves the natural environment as an attraction, while the prescriptive component entails the impacts of visitation on the natural environment. In justifying ecotourism, proponents often assume that its activities are not environmentally harmful because of the small visitor numbers and more importantly, visitors are interested in aspects of the environment and are therefore assumed to respect natural phenomena. Some contend that ecotourists are even motivated to conserve the environment, so one would expect them to generate little or no negative environmental impact.

The paradox of ecotourism, however, is that the incentive effect is realised only when the visitation numbers are high enough to generate income that is greater than what could have been generated by other competing sectors or activities like the extractive industries. This means "mass ecotourism" best activates the incentive effect. Yet the greater the amount of ecotourism activities, the greater 
the likelihood of causing damage to fragile environments (Weaver, 2002). This is particularly relevant because ecotourism is usually directed to unique environments which may have limited capacity to withstand excess pressure from human activities.

Impacts can be "direct" (effect of the visitors themselves) and "indirect" (effect of the infrastructure or activities necessary to provide the visitor experience). Some of the direct impacts include:

i. soil erosion and compaction;

ii. disturbance of wildlife;

iii. accidental introduction of exotic species; and

iv. increased frequency of wild fire (see Wall, 1994).

Conversely, some indirect impacts include:

i. reclamation of land for infrastructure (e.g., clearing of forests for hotels);

ii. generation of solid waste (e.g., rubbish/garbage);

iii. water and air pollution (e.g., effluent in rivers and oceans); and

iv. purchase of souvenirs encourage the utilisation of threatened or endangered species (e.g. animal hides, black coral).

Further, Rennings and Wiggering (1997) noted that existing definitions exclude travel-related resource consumption. But a major precondition for sustainability is the conservation of nonrenewable resources and waste emission within the assimilation capacity of ecosystems. The foregoing suggests that inadequate planning of ecotourism could cause enormous harm to the very resources it depends on and seek to conserve.

\subsubsection{Experiential Dimension}

In a review paper, on 'Experiential Tourism around the World and at Home', Smith (2006) cited Pine and Gilmore (1998) who stated that "Experiences are now seen as the latest economic progression (most advanced form of differentiated position along with premium pricing): extract commodities, make goods, deliver services, and stage experiences". Smith further noted that whereas goods are tangible and services are intangible, experiences are memorable. They are personal, revealed over a duration, and typically involve multiple sensations. Experiences occur across to sets of dimensions: customer participation (ranging from passive to active) and connection or environmental relationship (ranging from absorption to immersion). 
In the prescriptive component of ecotourism, most attention is generally focused on environmental sustainability. However, ecotourism should also be sustainable in other dimensions, including the experiential dimension. If the visitor experience is remarkably degraded, this will lead to a reduction in visitation that might eventually affect overall sustainability. Therefore, in order to ensure that sustainability is not jeopardised, managers of ecotourism sites should, as a basic requirement, monitor the quality of the visitor experience to determine what can be done to address concerns and to improve the quality of experience. The addition or removal of certain programmes, activities, or infrastructure is a means to facilitate improvement in the experiential dimension of ecotourism. However, the experience acquired also depends on how visitors affect each other. Such experiential impacts can be grouped into three categories (Roggenbuck, 1992:155):

i. Crowding - in which the quality of the experience is reduced by visitor perceptions that they saw too many other people during their visit.

ii. Conflict - in which the quality of the experience is reduced by visitor perceptions of incompatibility or animosity with other visitors.

iii. Environmental degradation - in which the quality of the experience is reduced by visitor perceptions of environmental deterioration caused by other visitors.

The experiential dimension of ecotourism embodies visitor satisfaction which is affected by a variety of factors and therefore difficult to measure (Manning, 1986; Ryan, 1995). According to Pearce (1988, cited in Hughes, 1991), satisfaction is expressed when at least some of the expectations of the visitor are fulfilled. It should therefore be noted that visitor satisfaction is a multifaceted concept which is primarily determined by visitors' attitudes before and after the trip (Hughes, 1991) to an ecotourism destination in this case. The overall attitude exhibited with respect to satisfaction also depends on how visitors affect each other and how they value the outcome of their experience. The quality of experience determines whether or not there will be repeat visits to the destination (see Laws, 1998).

Owing to the multifaceted nature of satisfaction, simplistic measurement of this concept could provide misleading information. For example, high levels of reported satisfaction in a particular cross sectional survey may lead managers to become complacent. Visitors responding to a survey questionnaire may report satisfaction while at the same time desiring improvement in certain facilities, activities, or conditions. Further, previous visitors who were unsatisfied during their visit would not be represented in the sample of current visitors, as they would have stopped coming to 
the site. Again, other potential visitors may never have come to the site due to possible negative publicity through word-of-mouth by earlier visitors who were not satisfied with the experience offered at the destination.

It is therefore imperative that managers ensure quality experience by addressing concern over environmental degradation, resulting from tourism or other causes, and its effect on the visitor experience. Thus, environmental integrity must be preserved if the visitor experience and satisfaction is to be maintained, thereby providing an additional rationale for nature conservation.

\subsubsection{Socio-cultural Dimension}

Implicit in the ecotourism concept is the interaction of individual actors, including visitors, natural area or park managers and local people within a socio-cultural environment. The level of interaction among these actors, according to Spangenberg (2002) depends on social norms governing societal interactions which are necessary preconditions for economic activities. In simple terms, the social dimension of ecotourism refers to individuals' skills, dedication, experiences and how these are shaped through interactions to affect the behaviour of the actors. The socio-cultural environment however serves as both an ecotourism attraction and a recipient of ecotourism's impacts due to the interaction of the actors. Hence, if the net impacts become too negative, the local sustainability of ecotourism can be hampered.

Often ecotourism activities involve relatively intense interaction between differing cultures of visitors and local people, and these differences may exacerbate negative socio-cultural impacts of ecotourism particularly on local communities. In some areas local people have also been sufficiently unhappy with ecotourism development and associated resource use restrictions and costs that they sabotaged the natural resource on which this development was based (Ogutu, 2002). This is mainly due to restrictions on use of land and natural resources as a result of new environmental conservation systems and its associated loss, without any corresponding or adequate compensation. These restrictions can cause significant change in socio-cultural arrangements in the local communities and change their main livelihood. The conservation systems sometimes even result in the dispossession of local people from their homes and aspects of their livelihoods. This consequently changes their surrounding from where they lived and worked (Anderson and Berglund, 2003). There is a substantial body of work that points to the way in which local populations can be 
dislocated and disadvantaged in creation of ecotourism destinations like parks and reserves (Akama, et. al., 1996; Neumann, 1998; 2000).

However, ecotourism is purported to respect and support local cultures and livelihoods. To avert possible negative consequences and ensure sustainability of ecotourism, many policy makers are now becoming aware of the need i) to incorporate local communities into the tourism development and natural area management process and ii) to understand and address the negative impacts on communities.

According to Lindberg and Johnson (1997), the net impacts, whether positive or negative, depends on how ecotourism was developed and this balance may affect local people's attitudes toward ecotourism. In this context, they outlined interactions which affect social impacts:

i. interaction with visitors - tourism can lead to satisfying relationships with visitors, even if those relationships are short lived.

ii. interaction within local people - tourism can affect local social relationships among residents. Sometimes, friendliness of local residents can decline.

iii. community/culture - because tourists often are motivated by the desire to experience the host community and its culture, tourism can affirm that culture and lead to community pride; it also can disrupt local cultures, particularly when international tourists visit remote areas with little historic foreign contact.

iv. influence over community decisions - studies have shown that residents are more supportive of tourism when they have been able to influence the tourism development process.

Invariably, these impacts would influence the attitudes of the actors, particularly local people and gravely affect the viability of ecotourism.

\subsubsection{The Economic Dimension}

As indicated earlier, there are many actors in the ecotourism "system" with differing objectives of participation. However, one common thing they all seek is economic benefit in various forms. Protected or natural area managers, for example, are interested in user fee revenues because funding allocations for managing natural areas and parks have increasingly declined around the world while the number of protected areas or national parks keeps growing (Eagles, 1995; Reynolds, 1995). As a result, some of these protected area managers and conservationists have turned to ecotourism as a source of revenue, to finance at least ecotourism-related costs in the park that 
historically have been financed by governments or through donor funds. Local communities on the other hand embrace ecotourism due to its potential to generate jobs and income for the local people.

Obviously, the realisation of the economic potential of ecotourism to the benefit of all the actors hinges on the generation of revenue from user fees and establishment of ecotourism related ventures. Consequently, there have been numerous studies on user fees in the ecotourism context (e.g., Laarman and Gregersen, 1996; Lindberg and Enriquez, 1994; Lindberg, et. al., 1996; Mak and Moncur, 1995; Tisdell, 1996). The level of revenue obtained is determined by the objectives for managing the area. Few scenarios are necessary to elucidate this point. First, if the ultimate objective is to generate revenue, then fees need to be relatively high which might have detrimental effects on local jobs or businesses. Second, if the objective is to attract more visitors to provide job opportunities for local people and businesses, then the ideal would be to set very low fees or even eliminate fees. Frequently however, ecotourism does not tend to generate the needed job opportunities for local people but rather generates costs that would be financed by usually poor local people or non-users (Lindberg, et. al., 1996). Thus Lindberg (1991) finds it particularly inappropriate for the relatively poor local people or non-users to subsidise the visits of relatively wealthy users mainly from developed countries who visit public natural or protected areas in developing countries.

In the case where ecotourism is increasingly able to generate needed jobs for local people, the economic value becomes obvious and therefore serves as an incentive for locals who otherwise would be poachers of non-timber forest products. Such incentives direct their support to natural resource conservation as it would be viewed as the source of the jobs (Lindberg, et. al., 1996). Likewise, if ecotourism is perceived by local people to generate more costs (Table 3.1 ) in terms of reduced access to the area and its resources than accrued benefits, it may reduce local support for the conservation of natural areas concerned.

Some authors (including Lindberg, 1991; Brandon, 1996) noted that more than $90 \%$ of tourism spending is thought to leak away from communities close to most nature or ecotourism sites which is disadvantageous to the economic development of the local area. However, though the number of jobs created in the wake of massive leakage will be low, even a few jobs can make a big difference in the livelihoods of local residents. That notwithstanding, promises of ecotourism benefits should not be exaggerated, in order to avoid any backlash if the reality fails to live up to expectations of the people (see Ross and Wall, 1999a). 
Table 2.2 Summary of the Generally Anticipated Benefits and Costs of Ecotourism

\begin{tabular}{|c|c|c|}
\hline $\begin{array}{l}\text { Characteristic } \\
\text { Dimension }\end{array}$ & Positive Impacts/ Benefits & Negative Impacts / Costs \\
\hline Environmental & $\begin{array}{l}\text { - incentive for conserving natural areas } \\
\text { - resources for environmental } \\
\text { conservation and management } \\
\text { - incentives to maintain or enhance the } \\
\text { physical environment } \\
\text { - engender an environmental ethic }\end{array}$ & $\begin{array}{l}\text { - damage to vegetation } \\
\text { - alteration of habitats } \\
\text { - inapt tourist activities, i.e. hunting } \\
\text { - disturbance of wildlife, soil erosion and } \\
\text { compaction } \\
\text { - pollution - air, noise and waste } \\
\text { - introduction of exotic species and } \\
\text { diseases }\end{array}$ \\
\hline Economic & $\begin{array}{l}\text { - foreign exchange earnings } \\
\text { - economic development and } \\
\text { diversification } \\
\text { - distribution of income to local } \\
\text { economies and communities } \\
\text { - tendency of ecotourists to spend more } \\
\text { and stay longer } \\
\text { - generation of income for conservation } \\
\text { - increased employment opportunities } \\
\text { and income throughout the year } \\
\text { - local infrastructure development }\end{array}$ & $\begin{array}{l}\text { - failure of total revenue to match costs of } \\
\text { ecotourism impacts } \\
\text { - increased burden on under-funded } \\
\text { resource management agencies } \\
\text { - loss of control of ecotourism related } \\
\text { businesses and resources to outsiders } \\
\text { - exclusion of local people from protected or } \\
\text { natural areas for ecotourism purposes } \\
\text { thereby reducing income, employment } \\
\text { and resource availability to local people } \\
\text { - loss of livelihood }\end{array}$ \\
\hline Socio-cultural & $\begin{array}{l}\text { - employment opportunities } \\
\text { - diversification of the economic base } \\
\text { - diversification of facilities and services } \\
\text { - assist in long-term conservation of } \\
\text { cultural heritage } \\
\text { - revitalisation of local cultures } \\
\text { - historical perspectives concerning } \\
\text { indigenous people and flora and fauna } \\
\text { - conservation of traditional culture } \\
\text { - encourage local communities to value } \\
\text { and benefit from natural cultural assets }\end{array}$ & $\begin{array}{l}\text { - over crowding and competition for space } \\
\text { - seasonality of activities, jobs and income } \\
\text { - diversion of resources (opportunity costs) } \\
\text { away from other activities / issues } \\
\text { - conflicts over access and appropriate use } \\
\text { - inappropriate commodification of local } \\
\text { cultures } \\
\text { - improper tourist behaviour } \\
\text { - disruption of the social fabric of the local } \\
\text { community }\end{array}$ \\
\hline Experiential & $\begin{array}{l}\text { - environment serve as field laboratory for } \\
\text { first hand learning } \\
\text { - enhanced positive attitude towards } \\
\text { conservation of natural resources } \\
\text { - interaction and appreciation of local } \\
\text { people and culture }\end{array}$ & $\begin{array}{l}\text { - over crowding reduces visitor experience } \\
\text { - conflicts reduce the quality of experience } \\
\text { among visitors and local people } \\
\text { - inappropriate commodification of natural } \\
\text { areas and resources } \\
\text { - cultural change }\end{array}$ \\
\hline
\end{tabular}

Sources: Jenkins and Wearing (2003:214-215); Buckley and Pannell (1990), Buckley (2000), Weaver (2001), and Tisdell (2003) 


\subsection{References}

Abbot, J. and Thomas, D. 2001. Understanding the Links between Conservation and Development in the Bemenda Highlands, Cameroon. World Development 29(7): 1115-1136

Akama, J.S., Lant, C.L. and Burnett, G.W. 1996. A Political-Ecology Approach to Wildlife Conservation in Kenya. Environmental Values 5: 335-47

Anderson, D.G. and Berglund, E. (eds.) 2003. Ethnographies of Conservation: Environmentalism and the Distribution of Privilege. Oxford: Berghahn

Berkes, F. 2004. Rethinking Community-Based Conservation. Conservation Biology 18(3): 621-630

Blamey, R. 1997. 'Ecotourism: The search for an operational definition', Journal of Sustainable Tourism, 5 (2): 109-130

Bottrill, C. G. and Pearce, D. G. 1995. Ecotourism: Towards a Key Elements Approach to Operationalizing the Concept. Journal of Sustainable Tourism 3(1): 45-54

Brandon, K. 1996. Ecotourism and Conservation: A Review of Key Issues. World Bank Environment Department Paper No. 033. Washington, DC: World Bank

Brandon, K. 1997. Policy and Practical Considerations in Land-Use Strategies for Biodiversity Conservation. In: Kramer, R., van Schaik, C. and Johnson, J. (eds.). Last Stand: Protected Areas and the Defence of Tropical Biodiversity. Oxford University Press, New York

Buckley, R. 1994. A Framework for Ecotourism. Annals of Tourism Research 21 (3): 661-665

Buckley, R. 2000. Neat Trends: Current Issues in Nature, Eco- and Adventure Tourism. International Journal of Tourism Research 2: 437-444

Buckley, R. and Pannell, J. 1990. Environmental Impacts of Tourism and Recreation in National Parks and Conservation Reserves. The Journal of Tourism Studies 1(1):24-32

Budowski, G. 1976. Tourism and Environmental Conservation: Conflicts, Coexistence, or Symbiosis. Environmental Conservation 3(1): 27-31

Campbell, L. M. 1999. Ecotourism in Rural Developing Countries. Annals of Tourism Research 26(3): 534-553

Campbell, L. M. 2000. Human Need in Rural Developing Areas: Perceptions of Wildlife Conservation Experts. The Canadian Geographer 44(2): 167-181

Cater, E. 1993. Ecotourism in the Third World: Problems for Sustainable Tourism Development. Tourism Management 14(2): 85-90

Cater, E. 1994. 'Introduction' In: Cater, E. and Lowman, G. (eds.). Ecotourism: a sustainable option? England: John Wiley \& Sons. 230pp

Cater, E. 1995. 'Environmental Contradictions in Sustainable Tourism', The Geographical Journal, 161(1): 21-28

Christie, I. T. and Crompton, D. E. 2001. Tourism in Africa. Africa Region Working Paper Series No. 12. World Bank Group 
Collins, A. 1999. Tourism Development and Natural Capital. Annals of Tourism Research 26(1): 98 109

Dei, L. A. 2008. Ecotourism Planning and Development. In: Akyeampong, O. and Asiedu, A. B. (eds.) Tourism in Ghana: A modern Synthesis. Assemblies of God Literature Centre Ltd, Accra Ghana. p41-53

Diamantis, D. 1999. The Concept of Ecotourism: Evolution and Trends. Current Issues in Tourism 2 (2\&3): $93-122$

Donohoe H.M. and Needham, R.D. 2006. Ecotourism: The Evolving Contemporary Definition. Journal of Ecotourism 5:192-210

Drumm, A. and Moore, A. 2005. Ecotourism Development - A Manual for Conservation Planners and Managers Volume 1: An Introduction to Ecotourism Planning, Second Edition. The Nature Conservancy, Arlington, Virginia, USA

Eagles, P.F. J. 1995. Key Issues in Ecotourism Management. Paper presented at the Western Australia Annual Tourism Conference, Perth, WA

Eagles, P. F. J., McCool, S. F. and Haynes, C. D. A. 2002. Sustainable Tourism in Protected Areas: Guidelines for Planning and Management. IUCN Gland, Switzerland and Cambridge, UK. xV + 183pp

Farrell, B. H. 1999. Conventional or Sustainable Tourism? No Room for Choice. Tourism Management 20: $189-191$

Farrell, B. H. and Runyan, D. 1991. Ecology and Tourism. Annals of Tourism Research 18: 26-40

Fennell, D. 2001. A Content Analysis of Ecotourism Definitions. Current Issues in Tourism 4: 403-421

Fennel, D. A. and Dowling, R. K. (eds.). 2003. Ecotourism Policy and Planning. Oxon: CABI Publishing

Forstner, K. 2004. Community Ventures and Access to Markets: The Role of Intermediaries in Marketing Rural Tourism Product. Development Policy Review 22(5): 497-514

Goodwin, H. 1996. In Pursuit of Ecotourism. Biodiversity and Conservation 5: 277-291

Hall, C. M. 2005. Tourism: Rethinking the Social Science of Mobility. UK: Pearson Prentice Hall

Harrison, D. 1996. Sustainability and Tourism: Reflections from a Muddy Pool. In: Briguglio, L., Archer, B., Jafari, J. and Wall, G. (eds) Sustainable Tourism in Small Islands and Small States: Issues and Policies. Printer Press, London, pp. 69-89

Holdgate, M. 1999. The Green Web-A Union for World Conservation. Earthscan, London, UK

Holland, J., Burian, M. and Dixey, L. 2003. Tourism in Poor Rural Areas: Diversifying the Product and Expanding the Benefits in Rural Uganda and the Czech Republic. PPT Working Paper No. 12 http://www.propoortourism.org.uk/12 rural areas.pdf (12.08.2010)

Honey, M. 1999. Ecotourism and Sustainable Development: Who Owns Paradise? Washington, D. C.: Island Press

Hughes, K. 1991. 'Tourist Satisfaction: A Guided "Cultural" Tour in North Queensland', Australian Psychologist 26: 3, $166-171$ 
Hunter, C. 2002. Aspects of the Sustainable Tourism Debate from a Natural Resources Perspective. In: Harris, R., Griffin T. and Williams, P. (eds.), Sustainable Tourism: A Global Perspective (pp 3-23). UK: Butterworth Heinemann

Jenkins, J. and Wearing, S. 2003. Ecotourism and Protected Areas in Australia. In: Fennell, D. A. and Dowling, R. K. (eds.) Ecotourism Policy and Planning. UK: CAB International. pp 205-233

King, D. A. and Stewart, W. P. 1996. Ecotourism and Commodification: Protecting People and Places. Biodiversity and Conservation 5: 293-305

Kiss, A. 2004. Is Community-based Ecotourism a Good Use of Biodiversity Conservation Funds? TRENDS in Ecology and Evolution 19(5): 232-237

Koch, E. 1994. Reality or Rhetoric? Ecotourism and Rural Reconstruction in South Africa. DP 54, Geneva: UNRISD

Kotey, E.N.A., Francois, J., Owusu, J.G.K., Yeboah, R., Amanor, K.S. and Antwi, L. 1998. Falling into Place. Policy that Works for Forests and People. Series no. 4. International Institute for Environment and Development, London

Laarman, J. G. and Gregersen, H. M. 1996. Pricing Policy in Nature-Based Tourism. Tourism Management 17(4):247-254

Laws, E. 1998. Conceptualizing Visitor Satisfaction Management in Heritage Settings: An Exploratory Blue Printing Analysis of Leeds Castle, Kent. Tourism Management, 19(6): 545- 554

Lindberg, K. 1991. Policies for Maximizing Nature Tourism's Ecological and Economic Benefits. Washington, DC: World Resources Institute

Lindberg, K. and Enriquez, J. 1994. An Analysis of Ecotourism's Economic Contribution to Conservation and Development in Belize. Report to the World Wildlife Fund (WWF -US) and the Ministry of Tourism and the Environment (Belize)

Lindberg, K. and. Johnson, R.L. 1997. Modelling Resident Attitudes toward Tourism. Annals of Tourism Research 24(2):402-424

Lindberg, K., Enriquez, J. and Sproule, K. 1996. Ecotourism Questioned: Case Studies from Belize. Annals of Tourism Research 23(3): 543-562

Mak, J., and Moncur, M.E.T. 1995. Sustainable Tourism Development: Managing Hawaii's "Unique" Touristic Resource - Hanauma Bay. Journal of Travel Research 33(4):51-57

Manning, R.E. 1986. Studies in Outdoor Recreation. Corvallis, OR: Oregon State University Press

McCool, S. F., Moisey, R. N., and Nickerson, N. P. 2001. What should Tourism Sustain? The Disconnect with Industry Perceptions of useful Indicators. Journal of Travel Research 40: 124 - 131

Mclvor, C. 1994. Management of Wildlife, Tourism and Local Communities in Zimbabwe. DP 53, Geneva: UNRISD

Michaelidou, M. and Decker, D. J. 2003. European Union Policy and Local Perspectives: Nature Conservation and Rural Communities in Cyprus. The Cyprus Review 15(2): 121-145 
Michaelidou, M., Decker, D. J. and Lassoie, J. P. 2002. The Interdependence of Ecosystem and Community Viability: A Theoretical Framework to Guide Research and Application. Journal of Society and Natural Resources 15(7): 599-616

Munt, I. 1994. Eco-tourism or Ego-tourism? Race and Class 36(1): 48-60

Neumann, R. P. 1997. Primitive Ideas: Protected Area Buffer Zones and the Politics of Land in Africa. Development and Change 28(3): 559-582

Neumann, R. P. 1998. Imposing wilderness: struggles over livelihood and nature preservation in Africa. Berkeley: University of California Press

Neumann, R. P. 2000. Land, Justice, and the Politics of Conservation in Tanzania. In: Zerner, C. (ed.) People, Plants, and Justice: The Politics of Nature Conservation. New York: Columbia University Press. Pp 117-33

Ogutu, Z. A. 2002. The Impact Of Ecotourism on Livelihood and Natural Resource Management in Eselenkei, Amboseli Ecosystem, Kenya. Land Degrad. Develop. 13: 251-256

Orams, M. B. 1995. Towards a more desirable form of Ecotourism. Tourism Management 16 (1): 3-8

Orams, M.B. 2001. Types of Ecotourism. In: Weaver, D.B. (ed.) The Encyclopaedia of Ecotourism. CABI Publishing, Wallingford, pp. 23-36

Pearce, P.L. 1988. The Ulysses Factor: Evaluating Visitors in Tourist Settings. New York. Springer Verlag

Peluso, N. L. 1993. Coercing Conservation?: The Politics of State Resource Control. Global Environmental Change 3(2): 199-217

Pine, B. J. II, and Gilmore, J. H. 1998. 'Welcome to the Experience Economy,' Harvard Business Review. pp. 97-105

Pleumaron, A. 1994. The Political Ecology of Tourism. The Ecologist 24 (4): 142 - 148 http://exacteditions.theecologist.org/exact/browse/307/308/6500/2/24/0/ (18.08.2010)

Public-Private Partnership Forum in Tourism. 2009. Making Tourism the Lead Sector of Ghana's Economy: National tourism marketing strategy 2009 - 2012. Accra, Ghana http://www.touringghana.com/documents/Abridged Ghana\%20 National Tourism Marketing Stra tegy.pdf $(10.06 .2010)$

Reed, M. G. 1997. Power Relations and Community-based Tourism Planning. Annals of Tourism Research 24(3): 566-591

Rennings, K. and Wiggerings, H. 1997. Steps towards Indicators of Sustainable Development: Linking Economic and Ecological Concepts. Ecological Economics 20: 25-36

Reynolds, J. 1995. National Parks and Protected Areas in the United States. Paper given to the North American Regional Meeting of the Commission on National Parks and Protected Areas. Banff National Park, Alberta, Canada 
Roggenbuck, J. W. 1992. Use of Persuasion to Reduce Resource Impacts and Visitor Conflicts. In: Manfredo, M.J. (ed.) Influencing Human Behavior. Champaign, Ill.: Sagamore Pub., Inc. pp. 155-161

Ross, S. and Wall, G. 1999a. Ecotourism: Towards Congruence between Theory and Practice. Tourism Management 20(6): 123-132

Rotha, K. S., Carson, T., Riebe, K., Cox, S. and von Kaschke, E. 2005. The Development of CommunityBased Natural Resources Management (CBNRM) in Cambodia. CBNRM Learning Initiative/WWFCambodia

Ryan, C. 1995. Researching Tourist Satisfaction: Issues, Concepts, Problems. London:Routledge

Sirakaya, E., Sasidharan, V. and Sönmez, S. 1999. Redefining Ecotourism: The Need for a Supply-Side View. Journal of Travel Research 38: 168-172

Sirakaya, E., Teye, V., and Sönmez, S. 2002. Understanding Residents' Support for Tourism Development in the Central Region of Ghana. Journal of Travel Research 41: 57-67. Sage Publications

Smith, W. L. 2006. Experiential Tourism around the World and at Home: Definitions and Standards. International Journal of Services and Standards 2(1):1-14 http://www.emporia.edu/business/cbedPDF/cbedwp05002.pdf (12.08.2010)

Spangenberg, J.H. 2002. Environmental Space and the Prism of Sustainability: Frameworks for Indicators Measuring Sustainable Development. Ecological Indicators 57: 1-15

Stecker, B., Schipulle, H. P. and Friedrichsen, J. 1996. Ecotourism: Potential for Conservation and Sustainable Use of Tropical Forests: A Case Study on the National Parks Taman Negara and EndauRompin in Malaysia. GTZ, Eschborn, Germany. p4 (http://www2.gtz.de/dokumente/bib/962255.pdf) (09.07.2008)

Swarbrooke, J. 1999. Sustainable Tourism Management. Willingford, UK: CAB International

Teye, V. B. 1999. Commentary: Tourism Plans and Planning Challenges in Ghana. Tourism Geographies 1(3): 283-292

Teye, V. B. 2000. Tourism Development Experience in Ghana. Development Policy Management Bulletin 7(1): 8-12

The International Ecotourism Society (TIES) (2006) Fact Sheet: Global Ecotourism. http://www.box.net/shared/static/eaukonjc0a.pdf (13.08.2008)

Tisdell, C. 1996. Ecotourism, Economics, and the Environment: Observations from China. Journal of Travel Research 34(4)11-19

Tisdell, C. 2003. Economic Aspects of Ecotourism: Wildlife-based Tourism and its Contribution to Nature. Sri Lankan Journal of Agricultural Economics 5(1): 83-95

Wall, G. 1994. Ecotourism: Old Wine in New Bottles? Trends 31(2): 4-9

Weaver, D. 2000. Ecotourism as a Tool for Development in Peripheral Regions. Paper Presented at The $4^{\text {th }}$ International Environmental Congress of Andorra: 'Ecotourism in Mountain Areas' July 17, 2002 (http://www.iea.ad/cbd/congres/cima02/David\%20Weaver.pdf) (03.06.2010) 
Weaver, D. 2001. Ecotourism in the Context of Other Tourism Types. In: Weaver, D. (ed.), The Encyclopedia of Ecotourism. pp. 73-83. Wallingford: CABI

Weaver, D. 2001. Ecotourism. Australia: John Wiley \& Sons

Weaver, D. 2002. Asian Ecotourism: Patterns and Themes. Tourism Geographies 4: 153-172

Weaver, D. and Lawton, L. 2007, 'Twenty Years On: The State of Contemporary Ecotourism Research'. Tourism Management 28 (5): 1168-1179

Wight, P. 2002. Reflections on the International Year of Ecotourism. International Ecotourism Monthly Year 4, Issue 43 (http://www.ecoclub.com/news/043/index.html) (10.07.2010)

Wood, M.E. 1991. Formulating the Ecotourism Society's Regional Action Plan. In: Kusler, J.A. (ed.) Ecotourism and Resource Conservation. pp. 80-89. WI: Madison

World Commission on Environment and Development. 1987. Our Common Future. London: Oxford University Press

Ziffer, K.A., 1989. Ecotourism: The Uneasy Alliance. Conservation International, Washington 


\section{Chapter Three: Research Concept and Methods}

\subsection{Context of Data Collection}

With the introduction of ecotourism, it is expected that local people will gain some benefits from natural and protected areas and thereby get motivated to contribute to conservation activities as noted in the concept. The study therefore focuses on the multidimensional impacts of ecotourism at the community level, while also assessing visitor satisfaction and preferences. However, the measurement of impacts of ecotourism in Ghana and particularly in the Kakum Conservation Area is a difficult task. There is a lack of readily available baseline information on which to deduce and determine the dimensions of any impacts since the inception of ecotourism in the protected area which aims at facilitating conservation and serving as a mechanism for rural development.

In consideration of the unavailability of reliable baseline data on the area, the study adopted a case study approach to assess the impacts of ecotourism in the communities and on the protected area. This involved selecting (sampling) sets of communities of different distances from the centre of ecotourism, in order to assess the dimensions of impacts at the local community level. The approach offered an opportunity to observe possible differences between communities that might be due to ecotourism activities or to the general protected area management system.

\subsection{Theoretical Framework and Indicators for Assessing Ecotourism Impacts}

The assessment relied on the framework of Ross and Wall (1999a) who proposed an efficient and symbiotic interaction between ecotourism, local community and the resources (protected area), with a central driving force of appropriate policy to manage these interactions (Figure 3.1). Amidst all the definitional challenges deduced from the analysis of several authors (see section 2.3), there is a consensus that ecotourism basically encompasses three common components: it is nature-based; offers opportunity for environmental education; and facilitates sustainability - which includes economic, ecological and social criteria (Diamantis, 1999). However, in spite of the abundant literature emphasizing the potential benefits, Ross and Wall (1999a) have noted that the theory of ecotourism is often not realised in practice. Thus, a gap exists between what ecotourism is in theory and what actually happens in practice. Hence, there is the need to design an effective means to assess the accomplishments, downsides and potentials of ecotourism (Ross and Wall, 1999b). This would avert any possible effects or implications that could negatively affect biodiversity and natural 
resources conservation, as well as the generating benefits to local communities or people in the destination areas.

Although there are guidelines to promote the successful implementation of ecotourism (Lindberg and Hawkins, 1993), finding a means to assess the impacts of ecotourism is no easy task considering the inability to globally adopt a universal definition to indicate what is or is not ecotourism. There is equally no universally accepted standard to measure the progress and impacts of ecotourism. Some authors (Ross and Wall, 1999a; Orams, 1995) have proposed frameworks and general indicators (Appendix 5) to aid in the assessment of the practical implementation and impacts of ecotourism at site level. The relationship indicators can be measured as variables that reflect the antagonistic or symbiotic interactions between people and resources. This study aims at evaluating the multidimensional impacts of ecotourism (see section 2.7) in communities adjacent to the Kakum Conservation Area (KCA). It relies principally on the evaluative framework (Figure 3.1) of Ross and Wall (1999a). The framework has already been applied and tested in assessing three different ecotourism programmes in North Sulawesi, Indonesia (Ross and Wall, 1999b); and also in two destinations in Hainan, China (Stone and Wall, 2003). So far it has not been applied in Africa or at least not in the Western part of the continent. The rational for adopting it is:

i. that it involves all the essential stakeholders that have to be considered (see section 2.5);

ii. that it includes all four impact dimensions that have been identified (see section 2.7); and

iii. that it contributes to the attempts of standardising methods for assessing the progress of ecotourism programmes.

Ross and Wall (1999b) wrote that "the success of conservation and ecotourism in a protected area depends on the building of harmonious relationships between natural areas and local residents, between local residents and tourism, and between tourism and protected resources, facilitated by management". Therefore, the framework (Figure 3.1) considers ecotourism in terms of synergistic links and uses a broad variety of indicators (Appendix 5) to determine whether the existing relationships are operating in a way to allow each to make positive contribution to the other (Stone and Wall, 2003; Ross and Wall, 1999a). Thus, efficient management of these interactions is likely to ensure the success of ecotourism at the site level. Wallace and Pierce (1996) also mentioned that an examination of the relationships between local communities, natural resources and tourism could be a starting point from which to evaluate an ecotourism site. This further emphasises the importance and utility of the adopted framework as a baseline for ecotourism impacts assessment. However, the 
current study goes further than just evaluating the inter-relationships. In addition, it examines the effects of any changes in resource use by local communities on conservation due to the benefits derived from ecotourism.

Figure 3.1 A Conceptual Framework for Analysing the Impact of Ecotourism

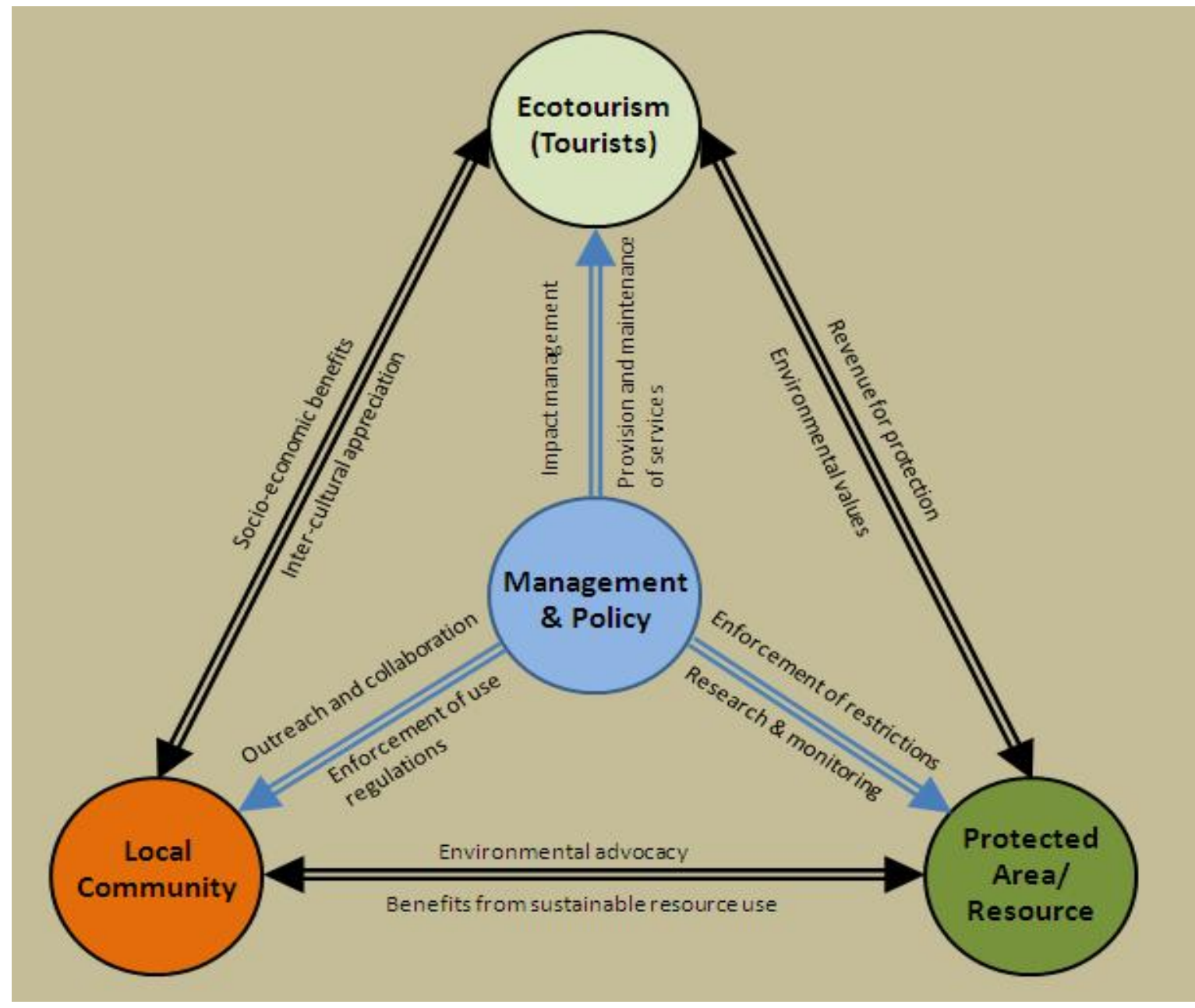

(Adapted from Ross and Wall, 1999a)

In theory, the basic functions of ecotourism include protection of natural areas; generation of financial resources; ensure local participation and capacity building; as well as education of both tourists and local people to conserve natural resources. Ross and Wall (1999a) argued that the success of an ecotourism site is reflected in the extent to which natural resources and biodiversity are protected, generate money to finance conservation and contribute to the local economy, educate tourists and the local people that promote environmental advocacy and as well involve the 
local people in conservation and development issues. Bushell and McCool (2007) contend that tourism provides considerable benefits that lead to greater appreciation of cultural and natural heritage, and a greater knowledge of the interplay between humans and their environment. Nevertheless, the value of these benefits would be appreciated differently depending on who is involved, and what interests and objectives they have for the natural resources.

Different actors or stakeholders assign different value systems for any kind of natural resources. While, local people may value biodiversity for its cultural and spiritual values aside the utilitarian values, ecotourists might be interested in the aesthetic values whereas scientists or managers would for example be interested in the services they provide. Therefore, these differences need to be factored into the planning and implementation of any programme that links nature conservation and development. Hence, the differences in stakeholder values and interest in biodiversity are linked to the characteristics of the stakeholders.

\subsubsection{Local People/Communities and Protected Areas}

The characteristics of local communities and of the surrounding biological resources influence an area's potential for ecotourism activities. Rátz (2000) mentioned that the natural aspects of the wider environment influence the social and cultural characteristics of a host community among other factors (e.g. political, economic). This also affects the relationship between the community and their resource use. In the peripheral locations common to many ecotourism sites the relationship between local communities and resource use, is characterised by high dependence on resource exploitation. Therefore, the implementation of use restrictions, for either political, economic or conservation reasons, may bring confusion and resentment on the part of the local people who are accustomed to using such lands and resources (Olindo, 1991). This is especially the case in a place where livelihood of the populous of the community in and around the protected area is based on subsistence. Implementation of use restrictions in support of conservation and ecotourism development must therefore come along with viable alternatives that do provide the immediate livelihood needs of the people. Hence, developing mechanisms for local residents to benefit directly from the establishment of protected areas in and around their homes must help to offset the loss of revenue from traditional extractive activities which is curtailed or prohibited by the establishment of a protected area. Otherwise, local people will become opponents of ecotourism and undermine its operation because they might perceive the ecotourism activity as a reason for losing their resource use rights. This is also why one of the essential elements of true ecotourism is the participation and involvement of the 
local communities and people living adjacent or in close proximity to the ecotourism site (Boo, 1992; Ceballos-Lascurain, 1996) to ensure that they benefit from ecotourism. Meeting this requirement would counter such obstacles to ecotourism and conservation. Therefore, it is essential to establish a positive or harmonious relationship between the local people and ecotourism management. In a harmonious relationship, people act as stewards of the surrounding natural resources or biodiversity because they get adequate economic and social benefits from ecotourism alongside the provision of ecological services. As Brandon (1993) puts it, local involvement may help maintain dialogue to facilitate understanding and addressing local needs and concerns, and strengthen the links between conservation and development goals with local benefits. According to a study from Nepal, attitudes towards ecotourism were more positive among people receiving economic benefits than those who were economically not benefiting from ecotourism at all (Mehta and Kellert, 1998).

\subsubsection{Ecotourism and Protection of Natural Resources}

Ecotourism by itself does not guarantee automatic benefits. The success and subsequent provision of benefits depends on good planning and management. III planned and poorly implemented ecotourism projects can easily become conventional tourism with all the associated negative impacts. Ecotourism thus presents a mix of opportunities and threats for protected or natural areas. Ecotourism in principle seeks to increase opportunities and to reduce threats. When an opportunity is realised, it becomes a benefit. But if a threat is not avoided, then it becomes a cost.

The contributions which ecotourism can make to biodiversity and the integrity of natural areas are essential. Since the provision of environmental education through the enhancement of opportunities to appreciate nature is fundamental for visitor's satisfaction, biodiversity and natural areas can provide this service in return for economic revenue, which can contribute to protected area conservation. For example, surplus from tourism revenues at Galapagos National Park, Ecuador, allows some funds to be redistributed to other protected areas in Ecuador (Ross and Wall, 1999a). In effect, protected areas can be viewed as natural laboratories and can provide unique interactive opportunities for promoting environmental stewardship for both locals and visitors (tourists). If they are well-managed, they do encourage appreciation of natural areas which then can result in environmental advocacy. Furthermore, people who enjoy a high quality experience in nature will be more willing to pay fees that can be used to maintain the protected area. Therefore, it is imperative that managers of protected areas ensure the quality of the available nature experiences that the area offers and use to instil "transformative values". Values, which, through learning experience with 
nature will yield greater environmental awareness, appreciation and respect for nature and thus ensure conservation and sustainable use of natural resources.

On the other hand, ecotourism, if not well managed could lead to stress wildlife populations which may affect the species composition, density and their community structure (Griffiths and van Schaik, 1993). Further, there is evidence of negative human impacts on vegetation along trails and campsites due to ecotourism (Deng, et. al., 2003). The extents to which these adverse effects are managed reflect the level of success of the conservation objective of ecotourism.

\subsubsection{Ecotourism and Local Communities}

There is no doubt that ecotourism development can contribute to improving a host community's socio-economic conditions and provide a rational for natural resource protection. However, this introduces some level of changes in the community. Nevertheless, the characteristics of a community are likely to be the determinant of the extent to which ecotourism affects its social changes and attitudes towards ecotourism and conservation. That means, the changes would not be the same from one community to the other. Tourism development, according to Kreag (2001), tends to alter the composition of the populations of communities. Likewise, Rátz (2000) emphasized that tourism can contribute to social and cultural changes in host communities, including changes in value systems, traditional lifestyles, family relationships, individual behaviour or community structure. These changes could be disruptions in traditional relationships among family members by affecting family structure and consumption patterns or declining community cohesion and morals. For example, social and familial cohesion in a community may encourage the spread of positive attitudes in contrast to a community where individuals are only concerned of their own personal benefits (Lindberg and Enriquez, 1994). Therefore, if positive attitudes to ecotourism are to be encouraged, residents living in or adjacent to a protected area should receive economic and social benefits or compensations, which will support or complement their livelihoods (Lindberg and Enriquez, 1994). However, it still remains to be demonstrated whether any gain of ecotourism benefits results in more positive attitudes towards conservation in the Kakum Conservation Area of Ghana.

In addition to economic benefits, ecotourism may also contribute to improved intercultural appreciation and understanding both for host communities and for tourists (McNeely, et. al., 1991). Tourism may therefore instil a sense of local pride to villagers and could promote or strengthen cultural heritage (Brandon, 1996). Examples of such positive contributions have been documented in countries in Asia (Gurung and De Coursey, 1994) but could the same be said of Ghana? 


\subsubsection{Policy and Management}

As much as the concept of ecotourism highlights conservation of natural resources and local culture, it requires a great amount of coordination among the different stakeholders or actors, including larger participation of local community. However, the level of efficiency of the coordination that would translate into improvement of the local economic status without future deterioration of the local environment depends on the kind of policy and management strategies that are implemented.

The theoretical framework takes into account that there are many other factors apart from those at the site-level, which influence the capacity for effective environmental education and revenue capturing. These are policy and management issues. National and regional policies could dictate the limits of possible contributions from tourism revenues (i.e. the flow of money to central agencies) as well as the quality of support to implement management strategies. Ecotourism will not be successful without effective management (Boo, 1993). The framework presented above (Figure 3.1) will be of little use in the absence of adequate institutional arrangements and administrative commitments. The development of positive relationships between people, natural resources and ecotourism is very unlikely to occur without implementation of effective policies, management strategies, and involvement of a wide range of organizations (Ross and Wall, 1999a). In addition, the qualities of protected area policies and implementers could influence everything from the extent of resource exploitation to the amount of revenue generated and the quality of interpretation as well as the enhancement and appreciation of local cultures.

According to Orams (1995), ecotourism management strategies are among others designed to control interactions between tourists and the natural environment as suggested in the numerous definitions of the concept. That is to protect the environment from detrimental impacts, and at the same time, to provide and promote enjoyable tourist experience. He noted that this objective should move beyond just visitor satisfaction and should incorporate learning, which facilitates attitude and behavioural change. Considering the synergy of interactions therefore, management strategies would be incomplete if local people are left out of the equation because as mentioned earlier, they could potentially undermine the tourism activity if they feel alienated. Hence, to achieve or ensure that the interactions are efficient, policy should provide the frame in which managing authorities/institutions could effectively undertake outreach programmes and provide well-enforced resource use zones or create avenues for incentives to local people. Further, the management framework needs to ensure provision of services that would promote visitor satisfaction while generally enforcing laid down restrictions on use of biodiversity in the natural or protected area 
concerned. Hence, the success of management strategies could therefore be measured in terms of its effectiveness in inducing change in lifestyle of tourists and the local people to actively engage in conservation, environmental advocacy and sustainable resource use.

\subsection{Institutions and the Policy Framework for Tourism Development}

The National Development Policy Framework articulates a 25-year (1996 - 2020) perspective for Ghana's socio-economic development, called the Ghana Vision 2020 (Government of Ghana, 1995). Thus Vision 2020 provides the national development objectives and policies which establish the framework for development planning including tourism. Vision 2020 identifies tourism as an important opportunity for economic development based on the natural, historic and the cultural resources of the country. In 1985, the tourism sector was accorded a priority status within the framework of Ghana Investment code PNDC L 116 and by 1987, a national tourism policy had been prepared to outline a framework for the development, promotion and marketing of the tourism sector. To facilitate the planning and development of tourism, the Ministry of Tourism with the assistance of United Nations Development Programme (UNDP) and the World Tourism Organisation (WTO) prepared a National Tourism Development Plan (NTDP). The NTDP established a general plan for the development of tourism in the country. The NTDP identified the potential for the development of ecotourism and community-based tourism throughout the country (Wildlife Department, 1997) using the wildlife protected areas as destinations for ecotourism activities.

There are three governmental institutions that are particularly important in the development of the tourism sector and promotion of its activities. They are the Ministry of Tourism, the Ghana Tourism Authority (formerly Ghana Tourist Board) and the Hotel, Catering and Tourism Training Centre.

The Ministry of Tourism is responsible for the development of tourism in Ghana. Its main functions are to formulate tourism policies and supervise the effectiveness of the policies. The goal of the ministry is to make tourism the number one foreign exchange earner as well as the major generator of employment in the country. The ministry has a policy to promote Ghana as a high-quality destination, thus discouraging mass tourism likely to impinge negatively on the socio-ecological environment. The government, through the ministry provides the necessary infrastructure, incentives and facilitation including marketing and promotion to encourage private sector investment. 
The Hotel, Catering and Tourism Training Centre (HOTTCAT) is a subvented body responsible for the training of personnel in the service delivery sector of the tourism industry. It provides specialised training for what must be a dynamic, constantly changing industry.

The Ghana Tourist Board, now Ghana Tourism Authority (GTA) is the Government of Ghana policy advisory and implementation body operating under the Ministry of Tourism. The main function of the Authority is to regulate and control standards in tourism facilities, conduct tourism market research, and promote Ghana as an attractive destination on the international tourism market.

The above institutions work together to ensure that the achievement of the tourism development objectives of Ghana is in accordance to the prescription of the Vision 2020 document. In spite of the country's focus on tourism development, the Wildlife Division who is responsible for managing protected areas has so far not demonstrated that it has prioritised ecotourism development. The Division has limited working relationship with the GTA despite the fact that the GTA could provide the technical and marketing assistance for the promotion of ecotourism. This is probably so because there is no specific policy on ecotourism development, nor is there any specific ecotourism development plans. There is also no mechanism to evaluate the impacts of tourism activities within the protected areas. The low priority accorded ecotourism is therefore seen as the most important constraint in the development of ecotourism. This is because some ecotourism opportunities could be pursued within the existing budget and personnel if instructions and guidelines were available (Wildlife Department, 1997).

\subsection{Research Design}

In order to assess the impacts, the study used both qualitative and quantitative approaches in the data collection to enrich the analysis and interpretations. This aimed at giving an impetus to the protected area and ecotourism management to improve conservation and rural development initiatives. Considering the multiple interactions of factors in the evaluative framework (Figure 3.1), appropriate sampling techniques were necessary to measure impact variables. In principle, it will be too difficult and expensive to measure the indicators of impact on the entire populations of all the communities living close to or adjacent to the conservation area. Sampling is therefore a way of selecting parts of a population for measurement (Scott, 1998).

Principally, stratified random sampling and systematic sampling were used for most of the data collection. In addition, focus group discussions and snowball (also known as reputation or chain 
referral) sampling (Neuman, 2006) were used to collect information that would hitherto not be easily obtained through a survey. Stratified sampling is used if the variables for data collection take on different mean values in different subpopulations (Lohr, 1999) and random sampling ensures that every member of the whole population has an equal and independent chance of being selected in the sample (Lohr, 1999; Underwood, 1997). Therefore the aim of subdividing the population into strata is to derive parts each of which are more homogenous than the whole population to reduce the within stratum variance (Lohr, 1999; Philip, 1994). Underwood (1997) cautioned that while randomisation of sampling allows a wider representation of the true population, it should be noted that samples taken from a population by this approach are not necessarily representative in any one particular case. This emphasizes the importance of subdividing the population into strata.

Bryman (2004) also hinted that the drawing of a simple random sample that ensures statistical representativeness in some data collection situation is impossible. Example is when the sampling has to do with individuals (key respondents or informants) who have in-depth knowledge about the history of an event or place. The practical mode of tracing such individuals (respondents) would therefore be through snowball sampling techniques. Snowball/reputation sampling is used to contact groups of people for whom there is no sampling frame (Bryman, 2004). Basically, a sample frame is the complete list of all the members of a population that we wish to study. Consequently, such techniques cannot produce statistically representative samples since they rely on social contacts between individuals to trace additional respondents (Beardsworth and Keil, 1992 cited in Bryman, 2004). The snowball and purposive sampling techniques were used to identify respondents for qualitative interviews and discussions. Neuman (2006) argued that the use of these non-probability sampling techniques focuses on identifying respondents who would provide relevant and quality information, rather than representativeness of the population. The use of purposive sampling technique is particularly important in selecting respondents with an in-depth knowledge about a subject matter. These techniques were used to contact village chiefs, elders, opinion leaders, and the selection of local residents for interviews and group discussions in all the selected communities.

Another source of social data collection is through focus groups. Focus group is a qualitative research technique in which people are 'interviewed' in a group discussion setting. It usually involves 6 to 12 people gathered to discuss few topics with a moderator (Neuman, 2006). This method is often combined with quantitative research. It creates an atmosphere, which usually makes people feel empowered among members of marginalised social groups, and therefore the participants tend to express their opinions and ideas freely. The hallmark of the focus group is their explicit use of group interaction to produce data and insights that would be less accessible without the interaction found 
in a group (Morgan, 1997). This allows the researcher to observe how the people react and talk about the presented topic, which tends to aid interpretation of the quantitative data. However, it should also be noted that focus group discussions produce fewer ideas than individual interviews (Neuman, 2006) because the discussions concentrate on few issues. However, this will aid the efforts to assess whether ecotourism management is enhancing the well-being of the local communities and promoting involvement in conservation.

\subsection{Sampling Technique and Data Collection}

Since the nature of the study was based on exploring and understanding the dimension of issues related to perceived impacts of protected area conservation and ecotourism management, the selection of respondents' sample size did not concentrate on the number. It rather stressed on the quality of respondents or discussants and their potential know-how to answer the questions and provide relevant information for analysis. There are a number of methods to collect information for the assessment of perceived impacts. Snowball, purposive, focus group discussions and stratified sampling techniques were employed in consideration of their merits and demerits as explained in 3.4). The above methods were selected to assess the effectiveness of ecotourism's contribution to local area development and biodiversity conservation in the Kakum Conservation Area. These methods are complimentary and therefore were used in a combination fashion to access all relevant socio-economic data. This ensured that the overall data or information was reflective of the actual situation in the village communities.

The selection of village communities and households was done through stratified sampling techniques. The communities were selected based on their location and accessibility, characteristics, and socio-demographic backgrounds. The snowball and purposive sampling techniques afforded the opportunity to establish a good rapport with the local communities, chiefs and elders which subsequently facilitated semi-structured interviews with household heads and representatives in the community surveys.

Likert-type scale (5-point scale statements) recommended by Maddox (1985) for tourism impact studies, open-ended and closed questions that measure ecotourism impacts (both, positive and negative) in five categories (social impacts, cultural impacts, economic impacts, environmental impacts, and overall impacts) were developed into questionnaires and administered to randomly selected household respondents in each community. 


\subsubsection{Primary Data Collection}

\subsubsection{Open Interviews}

Open interviews were conducted with 26 respondents (consisting of chiefs, elders and opinion leaders) in the eight selected research communities. Policy makers were also interviewed. These included the Park Manager, the Law Enforcement Officer, and the Manager of Collaborative Resource Management of the Kakum Conservation Area. In addition, the Executive Director of the Ghana Heritage Conservation Trust as well as the Manager of the Commercial Development Unit together with the Community Relations Officer of the Ghana Wildlife Division of the Forestry Commission were interviewed.

Snowball sampling techniques was used to contact key respondents or people (chiefs, elders and opinion leaders) who were thought to have in-depth knowledge about the sampled communities in relation to communal/livelihood activities before the protected area was established, what possible changes might have occurred as a result, influence of ecotourism in the communities and their involvement in nature conservation efforts.

\subsubsection{Focus Group Discussion}

Identified focus groups within each sampled community discussed their perceptions of ecotourism, involvement in conservation of the protected area and relevant changes in livelihood strategies as a result of the protected area management and ecotourism activities. In addition, the focus group discussions assisted in validating information gathered from both the stratified and the snowball sampling techniques. The group discussions aimed at increasing the chances of understanding the community-natural resource-ecotourism inter-relationship. Again, it enhanced finding out the existing relationship between the local people and the managing authorities and how that influences the use of resources in the conservation area. Hypothetically, it is expected that if the protected area management strategies and ecotourism activities are beneficial to the local people, then they would show positive attitudes and contribute to conservation (Figure 3.1).

Ideally, any ecotourism programme is expected to promote conservation of the natural resources upon which the industry depends. Hence, from the evaluative framework, if ecotourism is properly functioning to achieve this objective then, it should induce sustainable resource use among the local communities apart from ensuring that tourists' activities exert minimum impacts. Thus, it should lead to reduction in the degradation of the resources and even show some level of maintenance if not 
improvement in the ecology within the areas where ecotourism activities take place as well as around the accessible forest areas for the local people. Hence the group discussions sort to elicit the opinions of the community.

\subsubsection{Semi-structured Interviews}

Semi-structured household interview/survey was conducted with 141 households in the selected communities. This was designed to elicit information regarding local peoples' involvement in ecotourism and their perceptions of the impact of ecotourism in their area. The survey also looked at their involvement in conservation management and to understand the perceptions about biodiversity conservation in the Kakum Conservation Area. It was also a means to elicit information on their future expectations of ecotourism and the desired changes or improvements in the management of the protected area. Finally the survey was used to gather relevant demographic information about the respondents and their households.

Similarly, a survey involving 423 tourists/visitors was conducted at the visitor centre. The survey collected demographic information about the tourists, reasons of visiting, itineraries, preferences for improvements in recreation activities, satisfaction as well as their impressions on the protection and management of the conservation.

\subsubsection{Extraction}

This is the collection of data from documents, records, or other archival sources. It generally includes using an abstraction process to cull the information desired from the sources (Harrell and Bradley, 2009). Extraction was used in collecting information on tourists or visitors. The information included the country of origin, activities they engage in at Kakum, and whether they are adults or school children. Likewise, this method was used to gather information on poaching and serious offenses in the protected area. Serious offenses were recorded on a standard patrol records form designed by the Wildlife Division. These offences include: snares recovered or confiscated, empty cartridges found in the protected area, gun-shorts heard during patrols, poacher camps observed, poachers observed or arrested, fire arms confiscated and animals found dead due to poaching activities.

\subsubsection{Secondary Data Collection}

These are datasets that already exist. In this study, published and unpublished reports, maps, and brochures where used to collect information to supplement the primary data collected during the interviews. These secondary information sources helped in understanding the history and 
establishment of the conservation area, the management strategy used in protecting the area as well as the legal backing of the conservation area.

\subsection{Resources and Research Materials}

In order to gather relevant information, various resources and materials were used throughout the fieldwork. These are outlined in the table 3.1 below:

Table 3.1 Resources and Materials used During Fieldwork

\begin{tabular}{|c|c|c|}
\hline Description & Types & Purposes \\
\hline Local assistants & Resources & $\begin{array}{l}\text { Facilitating communication and arranging meetings with village } \\
\text { chiefs and opinion leaders, assisting in household surveys }\end{array}$ \\
\hline Facilitators & Resources & Facilitating the organisation of group meetings and discussions \\
\hline Questionnaires & Material & $\begin{array}{l}\text { Directing and supporting the process of semi-structures, } \\
\text { informal and expert interviews, and surveys of visitors, selected } \\
\text { village communities }\end{array}$ \\
\hline Secondary data & Material & $\begin{array}{l}\text { Reviewing reports and other research findings relevant to the } \\
\text { research area, management plans, conservation and tourism } \\
\text { policies, compilation of visitor statistics and other relevant } \\
\text { information about the characteristics and management of } \\
\text { protected areas and the research area. }\end{array}$ \\
\hline Discussion toolkits & Material & $\begin{array}{l}\text { Supporting the process of group discussions with } \\
\text { representatives of the selected village communities }\end{array}$ \\
\hline $\begin{array}{l}\text { Voice recorder, } \\
\text { digital camera and } \\
\text { notepad }\end{array}$ & Material & $\begin{array}{l}\text { Recording verbal responses of interviewees and writing notes } \\
\text { on observations during fieldwork (however, voice recorder was } \\
\text { used only with the permission of interviewees), taking pictures }\end{array}$ \\
\hline Maps of area & Material & $\begin{array}{l}\text { Identifying research area and specific village communities, } \\
\text { characterise research area and planning field visits }\end{array}$ \\
\hline
\end{tabular}

\subsection{Interview Procedure and Response}

For the Open Interviews and group discussions, a digital recorder was used to record all interviews and discussions with the permission of the respondents or group. The recorded interviews and discussions were played back and parts were transcribed immediately following the interview. This allowed the researcher to underline the common views expressed and where necessary, to conduct follow-up interviews. In the case of the interviews with chiefs, elders and opinion leader in the communities, the interviews were held in the local language. 
Semi-structured interviews were administered face-to-face with either the head of the household or the member of the household most willing to participate in the interview. All interviews were conducted by myself after seeking permission from the chief and elders of the selected communities. The interviews were conducted with a paper copy of the interview questionnaire. The questions were read to the respondents and responses were immediately entered into the questionnaire. If questions were not understood, I attempted to rephrase them in a manner that remained neutral but helped respondents to understand the meaning of the question. The interviews lasted from 20 minutes to about 1 hour depending on the respondent and his or her knowledge about the subjects addressed in the interview. Although the original questionnaire is in English, all the household interviews were conducted in the local language to allow easy expression of opinion by the respondents.

Visitor / tourist survey were conducted with visitors who had taken part in an activity in the conservation area. They were approached as they returned to the visitor centre. The purpose of the research was explained to them and those who were willing to spend some time were given the survey questionnaire which they filled-out and handed back to the researcher immediately or before they left the centre.

Response Rate - Of the 160 households originally included in the stratified sample, 141 could be realised. The response rate was $88 \%$. Altogether, nine households refused to be included in the interview. The other 10 households subtly indicated that they were not interested in being interviewed. After repeated follow-up visits where either no one was at home or I was asked to come back at another time, I decided to only deal with the households that were more willing.

For most interviews, there was a general sense of openness. However, some respondents expressed that they did not know much about ecotourism or the management of the conservation area. Their answers were short and direct with very little elaboration. However, some residents were very interested in being interviewed and spent a large amount of time during the interview. They were thorough in answering questions, and some engaged me in general discussion after the interview was completed.

With respect to the visitor survey, a total of 500 sets of questionnaires were distributed to visitors at the visitor centre. Though the visitors were asked to submit the filled-out questionnaires to the research before leaving the visitor centre, 45 of the questionnaires were not returned and another 32 could not be included because more than half of the questions were not answered. Hence, the 
response rate based on the correctly filled-out and returned questionnaires was $84.6 \%$ (423). Frequently, more Ghanaian visitors were not interested in taking part in the visitor survey compared to the foreign counterparts. In this regard it can be assumed that most of the un-returned questionnaires can be attributed to the Ghanaian visitors.

\subsection{Research Constraints}

Field work is inevitable in accessing relevant primary information and data for a study of this nature. However, after a preliminary field visit to village communities in the research area, it became evidently clear that the community livelihood system and social structure were too complicated to allow for easy access to information. This was also compounded by the relatively low level of formal education. Generally, I had to get along with peoples schedules which practically did not follow any strict time plans. Any emerging issue or activity took precedence over a pre-arranged meeting or discussion and therefore in some cases, appointments had to be cancelled and re-scheduled in just few minutes before they took place. When such incidence occurred, it subsequently affected other plans in the fieldwork schedule.

Another challenge was to deal with trust and expectations of the local people. The majority of them seem to be in research fatigue and are not willing to spend time talking about issues related to the conservation area. A critical observation that was made in all the selected village communities was that, whenever I introduced myself to any individual or group of people and stated that I was conducting a study related to the protected area, they did ask whether I was working for the Wildlife Division (usually with the question, are you a Wildlife Officer?). When I took time to explain that I was a researcher, their initial reaction suggests that they were not interested to talk about the protected area and related issues. To quote the most common phrase they used: "you (i.e. researchers, journalists and environmental activists) always come to just listen to our grievances and complaints and yet nothing happens". This suggests that many researchers or investigators have been to them for information and possibly promised things that never happened. This generally made it difficult to organise people for the group discussions. Furthermore, the obvious male domination in rural communities in Ghana did limit the participation of females in the group discussions even though extra effort was made to encourage females to join in the discussions.

Also political pressure or influence in the traditional administrative system seems to underline the responses of some informants, particularly the opinion leaders. This makes it difficult for an outsider (researcher) to fully appreciate the reality of situations in the communities. For example, while there 
is a sense of appreciation for the establishment of the protected area, on the other hand there are serious complaints about betrayal and lack of access to resources in the area. Usually both the "praise" and "complain" occurred within the same discussion session which makes it difficult to fully understand their position concerning the conservation area. It was therefore important to pay much attention to possible exaggeration in responses from interviewees in order to avoid collecting unreliable data. Some respondents tried to complain more about their vulnerabilities and poverty, irrespective of the subject under discussion, in attempt to make outsiders know about their problems. These respondents expected that the researcher should find potential benefactors to help them solve their problems.

Poor infrastructure facility, particularly road network was also a major challenge during the fieldwork. This made it difficult to access many of the village communities and visit them frequently to build enough trust between researcher and local people. Building trust is very important in any fieldwork situation because it allows an open and free discussion between you (researcher) and the people you work with. In a trust and mutual working situation, there are better chances that relevant information will not be withheld or issues will not be exaggerated, which eventually could affect the final analysis of the information.

\subsection{Scope of Data Analysis}

The data from the interviews, discussions and questionnaire survey were coded. Coding data simply means systematically reorganizing the raw data into a format that is readable to machine for the purpose of analysis (Neuman, 2006). The coded data were then analysed with the Statistical Package for the Social Sciences software (SPSS Ver. 16). Different groups in a community or stakeholders may have different interests in ecotourism and conservation. There is also the likelihood to have different perceptions of the contributions of ecotourism to socio-cultural and economic well-being of the people. Hence, the analysis identified the differences among the different communities and groups.

Attitude and perception data were collected using 5-point scale statements. A scale adds together a person's score on a number of different variables to arrive at an overall score on a broader concept (de Vaus, 2002). The reliability of a scale according to Pallant (2006) can vary depending on the sample that it is used with. Hence, it becomes necessary to check whether each scale used is reliable with a particular sample. In order to obtain overall attitudes and perceptions of the respondents on the attitude and perception scales, responses of each of the statements were re-coded as binary responses to reflect positive or negative attitudes. These were then subjected to binary logistic 
regression analysis using community and respondent characteristics as the explanatory variables (Landau and Everitt, 2004; Pallant, 2006) to assess the correlation among the attitudinal and perception variables. Further, cross tabulations were also used to assess the relationships between various variables under investigation.

A Strengths-Weaknesses-Opportunities-Threats (SWOT) analysis was also performed based on both the primary and secondary data collected during the field study. The SWOT factors that were produced were used in performing an external Threats (T) and Opportunities (O), and an internal Strengths (S) and Weaknesses (W) analysis, called the TOWS analysis to produce the TOWS strategies for management planning. The Analytic Hierarchy Process (AHP) was subsequently applied to priorities the TOWS strategies. Details of these analyses and processes are provided in the respective chapters. 


\subsection{References}

Boo, E. 1992. Tourism and the Environment: Pitfalls and Liabilities of Ecotourism Development. WTO News 9:2-4

Brandon, K. 1993. Basic Steps Toward Encouraging Local Participation in Nature Tourism Projects. In: Lindberg, K. and Hawkins, D. (eds.), Ecotourism: A Guide for Planners and Managers. Pp. 134-151. North Bennington: The Ecotourism Society

Bryman, A. 2004. Social Research Methods. Oxford University Press Inc., New York

Bushell, R. and McCool, S. F. 2007. Tourism as a Tool for Conservation and Support of Protected Areas: Setting the Agenda. In: Bushell, R. and Eagles, P. F. J. (eds.).Tourism and Protected Areas: Benefits Beyond Boundaries. CABI, Oxfordshire. UK. Pp 12-26

Ceballos-Lascurain, H. 1996. Tourism, Ecotourism and Protected Areas: The State of Nature Based Tourism around the World and Guidelines for its Development. IUCN, Gland, Switzerland

De Vaus, D. 2002. Analyzing Social Science Data. London. Sage publications Ltd

Deng, J., Qiang, S., Walker, G. J., and Zhang, Y. 2003. Assessment on and Perception of Visitors' Environmental Impacts of Nature Touirsm: A Case Study of Zhangjiajie National Forest Park, China. Journal of Sustainable Tourism 11(6): 529-548

Diamantis, D. 1999. The Concept of Ecotourism: Evolution and Trends. Current Issues in Tourism 2(2\&3):93-122

Fennell, D. A. 2001. A Content Analysis of Ecotourism Definitions. Current Issues in Tourism 4(5):403421

Government of Ghana. 1995. Ghana - Vision 2020 (The First Step: 1996 - 2020). Presidential Report on Co-ordinated Programme of Economic and Social Development Policies. Assembly Press, Accra.

Griffiths, M. and Van Schaik, C. P. 1993. The Impacts of Human Traffic on the Abundance and Activity Periods of Sumatran Rain Forest Wildlife. Conservation Biology 7 (3):623-626

Gurung, C. P. and De Coursey, M. 1994. The Annapurna Conservation Area Project: A Pioneering Example of Sustainable Tourism? In: Cater, E. and Lowman, G. (eds.). Ecotourism: A Sustainable Option? Chichester: John Wiley and Sons. Pp 177-194

Harrell, M. C. and Bradley, M. A. 2009. Data Collection Methods: Semi-Structured Interviews and Focus Groups. RAND Corporation.

Kreag, G. 2001. The Impact of Tourism. Minnesota Sea Grant, Publication No. 13. University of Minnesota

Landau, S. and Everitt, B. S. 2004. A Handbook of Statistical Analysis using SPSS. Chapman \& Hall/CRC

Lindberg, K. and Enriquez, J. 1994. An Analysis of Ecotourism's Economic Contribution to Conservation and Development in Belize. Report to the World Wildlife Fund (WWF -US) and the Ministry of Tourism and the Environment (Belize)

Lindberg, K and Hawkins, D. (eds.). 1993. Ecotourism: A guide for planners and managers. North Bennington: The Ecotourism Society

Lohr, S. L. 1999. Sampling: Design and Analysis. Brooks/Cole Publishing Company. Pacific Grove. USA 
Maddox, R. N. 1985. Measuring satisfaction with tourism. Journal of Travel Research 23(3): 2-5

McNeely, J. A., Thorsell, J. W. and Ceballos-Lascurain, H. 1991. Guidelines for Development of Terrestrial and Marine National Parks and Protected Areas for Tourism. Gland, Switzerland: IUCN

Mehta, J. N. and Kellert, S. R. 1998. Local Attitude towards Community-Based Conservation Policy and Programmes in Nepal: A Case Study of the Makalu-Brun Conservation Area. Environmental Conservation 25(4):320-333

Morgan, D. L. 1997. Focus Groups as Qualitative Research. London: Sage Publication Inc

Neuman, L. W. 2006. Social Research Methods: Qualitative and Quantitative Approaches. Pearson Education, Inc

Olindo, P. 1991. The Old Man of Nature Tourism: Kenya. In: Whelan (ed.). Nature Tourism: Managing for the Environment. Washington, D.C.: Island Press pp23-38

Orams, M. B. 1995. Towards a more desirable form of Ecotourism. Tourism Management 16 (1): 3-8

Pallant, J. 2006. SPSS Survival Manual: A Step by Step Guide to Data Analysis Using SPSS version 12. Open university Press, U.K.

Philip, M. S. 1994. Measuring Trees and Forests. Oxon, U.K. CAB International

Rátz, T. 2000. Residents' Perceptions of the Socio-Cultural Impacts of Tourism at Lake Balaton, Hungary. In: Richards, G. and Hall, D. (eds.) Tourism and Sustainable Community Development. Routledge, London. Pp 37-47

Ross, S. and Wall, G. 1999a. Ecotourism: Towards Congruence between Theory and Practice. Tourism Management 20(6): 123-132

Ross, C. and Wall, G. 1999b. Evaluating Ecotourism: The Case of North Sulawesi, Indonesia. Tourism Management 20:673-682

Scott, C. T. 1998. Sampling Methods for Estimating Change in Forest Resources. Ecological Applications 8(2): 228-233

Stone, M. and Wall, G. 2003. Ecotourism and Community Development: Case Studies from Hainan, China. Environmental Management 33(1):12-24

Underwood, A. J. 1997. Experiments in Ecology: Their Logical Design and Interpretation Using Analysis of Variance. Cambridge University Press

Wallace, G. N. and Pierce, S. M. 1996. An Evaluation of Ecotourism in Amazonas, Brazil. Annals of Tourism Research 23(4): 843-873

Wildlife Department. 1997. Wildlife Development Plan. Vol. 5 Ecotourism. Wildlife Department, Accra 


\section{Chapter Four. The Protected Area System of Ghana and the Study Area}

\subsection{Wildlife Protected Areas of Ghana}

Ghana has six categorised ecological zones, of which efforts are being made to protect representative species of each zone, namely: the Deciduous forest, Semi-deciduous forest, Coastal Savannah, Forest-Savannah transition, Guinea Savannah, and the Sudan Savannah. The need to conserve and sustainably manage Ghana's wildlife heritage has resulted in the creation of numerous protected areas. The International Union for the Conservation of Nature (IUCN) defines protected area as "an area of land and/or sea especially dedicated to the protection of biological diversity, and of natural and associated cultural resources, and managed through legal or other effective means" (McNeely, 1993). Under this definition, the IUCN identifies six categorises of protected areas based on the management objectives and strategy. The following are the brief description of the categories (IUCN, 1994):

- Category I: Strict Nature Reserve/Wilderness Area - protected area managed mainly for science or wilderness protection.

- Category II: National Park - protected area mainly managed for ecosystem protection and recreation.

- Category III: National Monument - protected area managed for the conservation of a specific natural feature.

- Category IV: Habitat/Species Management Area - protected area designated for conservation through management intervention.

- Category V: Protected Landscape/Seascape - protected area designated mainly for the protection of landscape or seascape and recreation.

- Category VI: Managed Resource Protected Area - protected area managed mainly for the sustainable use of natural resources.

According to these categories and based on the related management objectives, most protected areas are first and foremost dedicated to conservation. Hence local communities are allowed to continue traditional resource use only if their activities do not interfere with the goals of conservation. Therefore it is only category VI that allows for any type of use other than recreation.

Ghana has over 321 legally constituted protected areas (Earth Trends, 2003) of which 24 are designated as wildlife protected areas (WPAs). It appears that Ghana uses the 1978 equivalent 
protected area category names (IUCN, 1994) and therefore the equivalence will be indicated where appropriate. Ghana's WPA network includes 1 Strict Nature Reserve (Category I), 7 National Parks (Category II), 5 Wildlife Sanctuaries (equivalent to category IV), 6 Resource Reserves (equivalent to category VI), and 5 Ramsar sites. The Ramsar sites in Ghana are wetland areas located at the coast or estuaries of some rivers which are the habitats of important wildlife species. Table 4.1 categorises and gives indication of the location (administrative regions), vegetation type, area and the year in which the WPA was gazetted. Figure 4.1 also shows the spatial distribution of the WPAs. The areas shaded (and code numbered 1 - 5) indicate the locations of the coastal Ramsar sites; whilst the areas code numbered $6-20$ are the locations of the national parks, resource reserves, and sanctuaries.

The network of these WPAs, classified under the IUCN categories, covers over $5.6 \%$ of the terrestrial area of Ghana and adequately represents the diversity of ecosystems within the country. The following ecosystems are represented: Guinean savannah woodland (Mole), transition between dry forest and guinea savannah (Bui), dry semi-deciduous forest (Kyabobo), moist evergreen forest (Kakum). The Bia National Park is located in the transitional zone between moist-evergreen and moist semi-deciduous forest types, and Ankasa Resource Reserve in the wet evergreen zone, whilst the Shai Hills Resource Reserve is located in the coastal savannah area (UICN/PACO, 2010).

The official establishment of forest reserves and wildlife protected areas evolved during the colonial administration. Hence, majority of the forest reservations, according to Kotey et. al., (1998), took place in the 1920s and '30s, although some reservations were being created until the end of the 1940s. Most of the reserves were established through negotiation with chiefs and traditional authorities. The reservations were however made possible either through the 1927 Forest Ordinance or the Native Authorities Ordinance (which enabled authorities to constitute forest reserves under their bylaws). Subsequently, some of these reserves have become wildlife protected areas. The legal frameworks for wildlife governance were also formulated to guide the use, protection and management. For example, The Wild Animals Preservation Act of 1961 regulates the use and exploitation of wildlife in Ghana and establishes the Government's right to create protected areas. The Wildlife Reserves Regulations: 1971, L.I. 710, and the Wildlife Conservation Regulations: 1971, L.I. 685 also provide details of management (World Bank, 2006). 
Figure 4.1 Map of Wildlife Protected Areas and Ecotourism Sites in Ghana

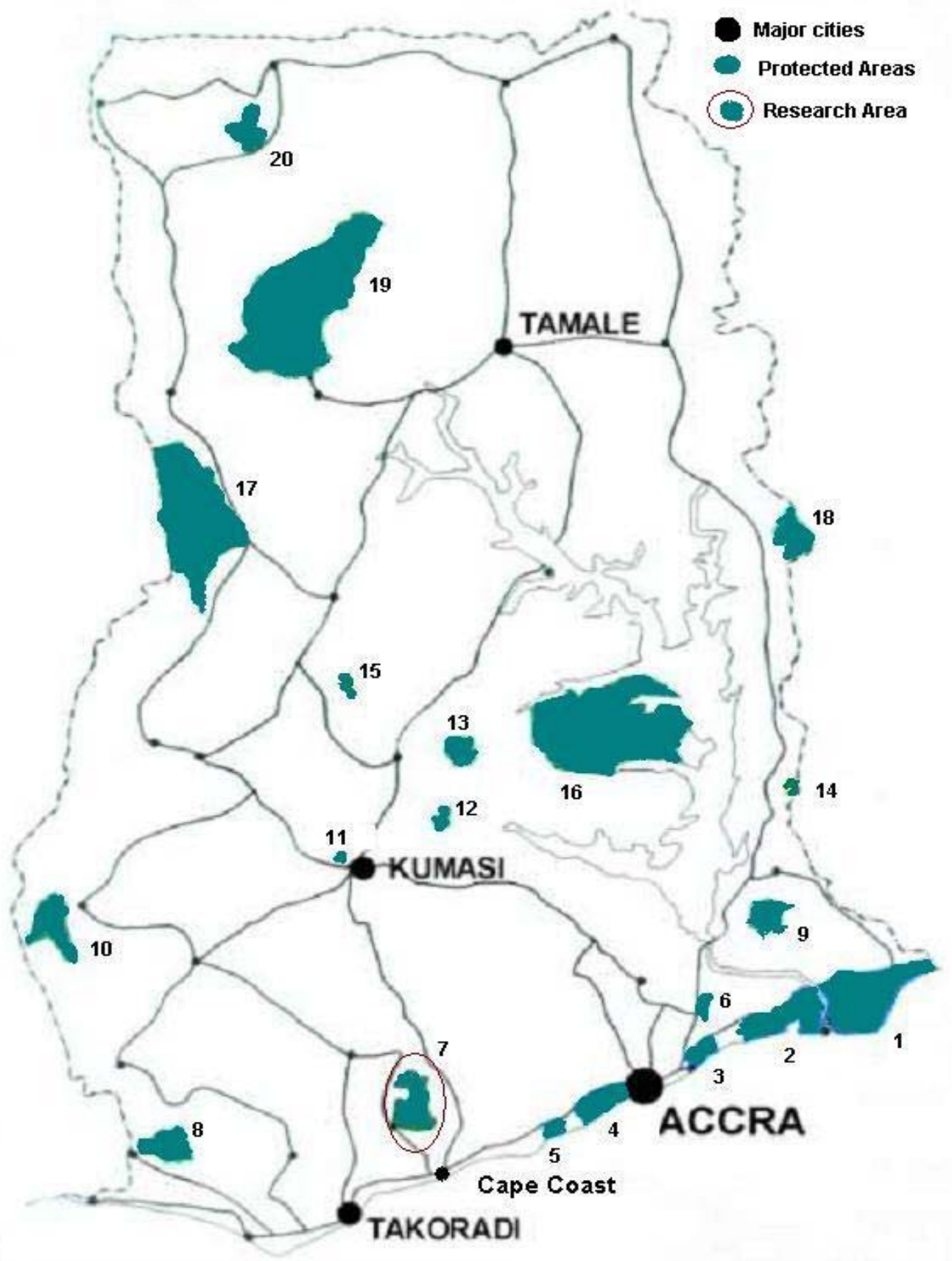

Source: Modified from EPA, 2009 
Table 4.1 Wildlife Protected Areas in Ghana

\begin{tabular}{|c|c|c|c|c|}
\hline \multicolumn{5}{|l|}{ Inland Protected Areas } \\
\hline National Parks & $\begin{array}{l}\text { Region }^{1} \text { of } \\
\text { Location }\end{array}$ & Vegetation Type & Area $\left(\mathrm{km}^{2}\right)^{2}$ & Year $^{3}$ \\
\hline 1. Bia National Park (BNP) & Western & $\begin{array}{l}\text { Moist evergreen to Semi } \\
\text { deci- duous forest) }\end{array}$ & $306(10)$ & 1974 \\
\hline 2. Bui National Park & Brong-Ahafo & Woodland Savannah & $1821(17)$ & 1971 \\
\hline 3. Digya National Park & Brong-Ahafo & Woodland Savannah & $3478(16)$ & 1971 \\
\hline 4. Kakum National Park (KNP) & Central & Moist evergreen forest & $360(7)$ & 1992 \\
\hline 5. Nini-Suhien National Park (NSNP) & Western & Wet evergreen forest & $509(8)$ & 1976 \\
\hline 6. Kyabobo National Park & Volta & Semi deciduous forest & $360(18)$ & 1993 \\
\hline 7. Mole National Park & Northern & Woodland savannah & $4577(19)$ & 1971 \\
\hline \multicolumn{5}{|l|}{ Resource Reserves } \\
\hline 1. Ankasa Resource Reserve & Western & Wet evergreen forest & $\begin{array}{ll}\text { Part } & \text { of } \\
\text { NSNP } & \\
\end{array}$ & 1976 \\
\hline 2. Assin-Attandanso Resource Reserve & Central & Moist evergreen forest & Part of KNP & 1992 \\
\hline 3. Bia Resource Reserve & Western & $\begin{array}{l}\text { Moist evergreen to Semi } \\
\text { deci-duous forest }\end{array}$ & Part of $B N P$ & 1974 \\
\hline 4. Gbele Resource Reserve & Upper West & Woodland savannah & $565(20)$ & 1975 \\
\hline 5. Kalakpa Resource Reserve & Volta & Woodland savannah & $320(9)$ & 1975 \\
\hline 6. Shai Hills Resource Reserve & Greater Accra & Coastal savannah & $51(6)$ & 1971 \\
\hline \multicolumn{5}{|l|}{ Strict Nature Reserve } \\
\hline 1. Kogyae Strict Resource Reserve & Brong-Ahafo & Semi deciduous forest & $386(13)$ & 1971 \\
\hline \multicolumn{5}{|l|}{ Wildlife Sanctuaries } \\
\hline 1. Agumatsa Wildlife Sanctuary* & Volta & Forest savannah transition & $3(14)$ & 1971 \\
\hline 2. Bomfobiri Wildlife Sanctuary & Ashanti & Semi deciduous forest & $53(12)$ & 1975 \\
\hline 3. Buaben-Fiema Monkey Sanctuary* & Brong-Ahafo & Semi deciduous forest & $4.4(15)$ & 1974 \\
\hline 4. Owabi Wildlife Sanctuary ${ }^{5}$ & Ashanti & Semi deciduous forest & $13(11)$ & 1971 \\
\hline 5. Tafi-Atome Monkey Sanctuary* & Volta & Forest savanna transition & 2.7 & \\
\hline \multicolumn{5}{|c|}{ Wet Lands of International Importance (Ramsar Coastal Wetland Sites) } \\
\hline 1. Anlo-Keta Lagoon Complex & Volta & Coastal wetland & $1277.8(1)$ & 1999 \\
\hline 2. Densu delta & Greater Accra & Coastal wetland & $46.2(4)$ & 1999 \\
\hline 3. Muni-Pomadze & Central & Coastal wetland & $95(5)$ & 1999 \\
\hline 4. Sakumo & Greater Accra & Coastal wetland & $13.4(3)$ & 1999 \\
\hline 5. Songor & Greater Accra & Coastal wetland & $511(2)$ & 1999 \\
\hline
\end{tabular}

Source: UICN/PACO, 2010; EPA, 2009; Birdlife, 2002; Wildlife Department, 1996, 1997; Ministry of Tourism, 1996

The forest and wildlife resources have long been major contributors to Ghana's economic development. They provide formal and informal employment and livelihoods for local people. Generally, traditional authorities in Ghana hold the allodial title to the land, and therefore have rights

\footnotetext{
${ }^{1}$ The Region of Location is in reference to political administrative regions of Ghana. Ghana is divided into ten administrative regions

${ }^{2}$ The numbers in brackets indicate the reference code numbers of the protected areas in Figure 3.1

${ }^{3}$ The year in which the area was officially gazetted as wildlife protected area

${ }^{4}$ Designated as international biosphere reserve

${ }^{5}$ Designated inland Ramsar site

${ }^{6}$ Yet to be gazetted; not located on the map of wildlife protected areas

* These are nationally recognised community initiated sanctuaries/protected areas
} 
to a share of benefits from timber royalties and forest lands. But when a land is reserved as a national park, it is no more under the allodial title. In theory, compensation is supposed to be paid to the relevant traditional authorities for reserving a piece of their land. Nevertheless, the compensation is not paid for resource reserves (World Bank, 2006).

Although the reservation of protected areas were effected through negotiations with traditional authorities, the earlier wildlife policies failed to recognize the socio-cultural, and utilitarian values that the Ghanaian societies placed upon the resources. The Policy was developed to focus on "protecting" wildlife from rural people (see Adams and McShane, 1996). However, the most current policy document, The 1994 Forest and Wildlife Policy, which lays the foundation for collaboration with key stakeholders (local people), aims at conservation and sustainable development of the nation's forest and wildlife resources for the maintenance of environmental quality and perpetual flow of optimum benefits to all segments of the Ghanaian society (MLF, 1994).

In spite of the new forest and wildlife policy, wildlife protected areas face numerous challenges which include poaching and land conversion due to expansion in agricultural activities around the protected areas. Poaching, which is the illegal gathering of wild plants and animals, continue in the protected areas due to the demand for game (bush meat) and other non-timber forest products for the sustenance of livelihood. In other cases however, the killing of wild animals is as a result of human-wildlife interactions particularly the destruction of food and cash crop farms (UICN/PACO, 2010; World Bank, 2006).

\subsection{Characteristics of the Study Area}

The Kakum Conservation Area was selected for this case study because the local people had some use rights and depended on the conservation area for various non-timber forest products (NTFPs) to sustain their rural livelihoods before the administration changed from the Forestry Division (FD) to the Wildlife Division (WD). However, the use rights changed on the assumption of management by the WD. The promise and hope of the local residents was to accrue some benefits from the enforcement of conservation regulations and the implementation and management of ecotourism activities through active participation and benefit sharing arrangements. That has however not been the case in practice and is met with few challenges. The Kakum Conservation area has a good law enforcement strategy. However, the severity of poaching in the conservation area is the highest among the wildlife protected areas in the country (UICN/PACO, 2010). The situation thus offers an 
opportunity to assess the extent to which ecotourism is in fact ensuring conservation of natural resources and supporting the livelihoods of local people within the conservation area.

\subsubsection{Establishment}

The area represents one of the last vestiges of the Upper Guinea forest ecosystem stretching from Guinea to Togo, which is categorized as one of the eight African biodiversity "hotspots" by Conservation International (Critical Ecosystem Partnership Fund, 2000). The conservation area (consisting of the Kakum National Park and the Assin Attandanso Resource Reserve) was originally established as forest reserves in 1931 and 1937 respectively (Hawthorne and Abu-Juam, 1993). Subsequently, the two reserves were reclassified as national park and resource reserve and gazetted in 1992 through the Wildlife Reserves Regulations (LI 1525) under the administrative jurisdiction of the Wildlife Division of Ghana (UICN/PACO, 2010; Adu-Nsiah, 1996; Agyare, 1995).

\subsubsection{Location and Size}

The Kakum Conservation Area, with a total area of $360 \mathrm{~km}^{2}$ (Figure 4.2), is located within the Central Region of Ghana (Figure 4.1). It is about 30km north of the regional capital, Cape Coast. The area falls within the Assin and Twifo Heman Lower Denkyera Districts and lies between latitude $5^{\circ} 20^{\prime}-5^{\circ} 40^{\prime}$ North and longitude $1^{\circ} 15^{\prime}-1^{\circ} 30^{\prime}$ West. The greater part of the reserve however falls within the Assin District (Wildlife Department, 1996; Agyare, 1995).

\subsubsection{Topography and Climatic Characteristics}

The conservation area forms an irregular block that is part of the Upper Guinean Rainforest of West Africa. The Kakum National Park is generally undulating with highlands ranging between $150-250 \mathrm{~m}$ above sea level. Most of the hills occur in the south-western corner rising up to $250 \mathrm{~m}$. It is also around this part that most of the tourism activities are concentrated. The Assin Attandanso part of the conservation area has general flat topography with hills ranging between $120-150 \mathrm{~m}$ above sea level (Wildlife Department, 1996). The conservation area has two-peak raining seasons. The major peak is between May-June, while the minor peak occurs between September-October. The annual average rainfall is between $1,500 \mathrm{~mm}$ and $1,750 \mathrm{~mm}$ (Wildlife Department, 1996). The average relative humidity is about $85 \%$ while average temp is between $20.2^{\circ} \mathrm{C}$ and $31.6^{\circ} \mathrm{C}$ (Agyare, 1995). 
Figure 4.2. Map of the Kakum Conservation Area ${ }^{7}$ Showing Some Major Communities

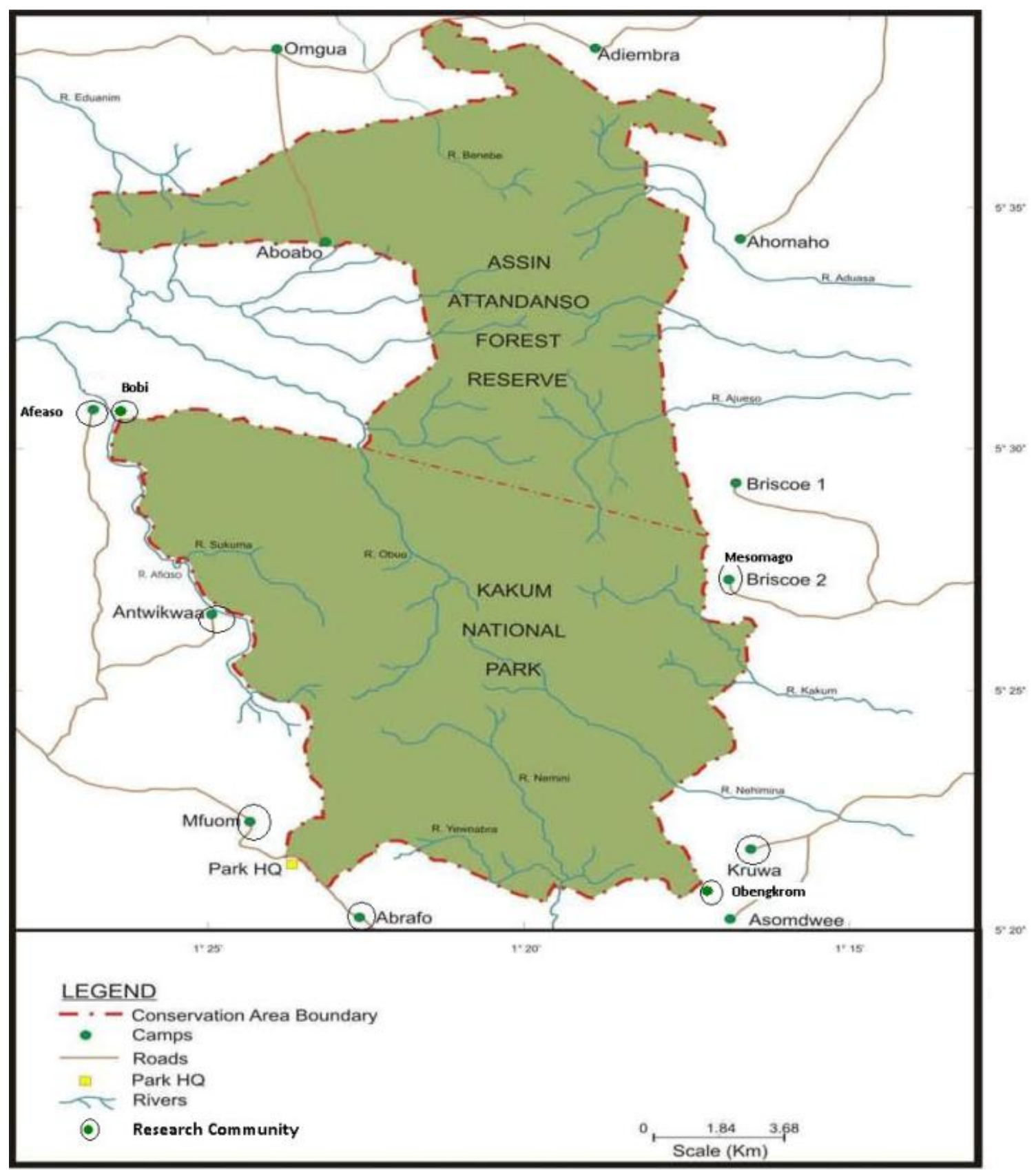

${ }^{7}$ The Kakum Conservation Area is coded 7 in Figure 4.1 


\subsubsection{Fauna of Kakum Conservation Area}

The Kakum Conservation Area (KCA) serves as a habitat for 40 mammal species including five endangered species. Wildlife species that are listed as endangered in the KCA include: Yellow-backed duiker, Diana monkey, Bongo, the Black and white colobus monkey and the forest elephant (UICN/PACO, 2010). The area is home to seven primate species and has a high of antelope, 200 bird species and over 450 species of already identified butterflies, including the species named Dioptes kakumi. Larsen (1994) collected and described this species which had not been seen, at least, in West Africa. Larsen estimated that the number of butterfly species existing in the Kakum conservation area could be at least 600 species, which is $70 \%$ of the total in Ghana. In addition, four species of reptiles have also been identified in the area. These are the monitor lizard, dwarf crocodile, Home's hinged tortoise and the serrated tortoise (UICN/PACO, 2010; Wildlife Department, 1996). A few carnivores also occur in the area but are in low density. They include the African civet, forest genet and palm civet. The conservation area is one of few forested areas in Ghana where species of special conservation interest still exists. Notable among them are the forest buffalo, bongo, colobus monkeys, water cherotain, the white breasted guinea fowl and the yellow-throated olive bird (Wildlife Department, 1996).

\subsubsection{Flora of Kakum Conservation Area}

The vegetation in the conservation area consists of 105 plant species. These include 57 trees, 10 shrubs, 9 climbers, 17 herbs and 12 grasses. The moist evergreen forest stand is closed with a canopy cover of about $70 \%$. The common emergent trees reach heights between $50-80 \mathrm{~m}$. The second storey, up to $40 \mathrm{~m}$, consists of trees of small and deeper crowns, straight trunks and supporting roots. Trees in the third storey usually reach between $5-18 \mathrm{~m}$ high. The following are the main identified features of the vegetation found in the Kakum Conservation Area (UICN/PACO, 2010; Wildlife Department, 1996):

- Swamp Forest: the swamp forest is poor in species and contains fewer trees than the surrounding forest. The low herbaceous layer is dominated by Marantheceae spp such as Marantochloa mannii, M. purpurea, Sarcophrynium brachystachys and Ataenidia conferta. The shrub layer often has scrambling shrubs such as Glyphae brevis, Myriathus arboreus and Paullinia pinnata. The trees include Raphia hookeri, Carapa procera, Xylopia spp and Uapaca guineensis.

- Periodic swamp forest: the number of tree species is more than in the swamp forest. Characteristic trees that are frequently encountered here include Alstonia boonei, Cleistopholis patens, Carapa procera, Mitragyina stipulosa and Raphia venifera. Scandent palms such as Calamus deeratus, 
Laccosperma secundiflora, L. opacum and Eremospatha macrocarpa also occur. The shrub layer is made up of scrambling shrubs like Glyphae brevis, Myriathus arboreus and Paullinia pinnata. The common herbs found in this characteristic forest community include Thaumatococcus daniellii, Sarcophrynium brachystachys and Ataenidia conferta.

- Riverine forest: this is an edaphic forest formation found on soils which, even though inundated or saturated only periodically at the peak of the rainy seasons, are maintained at higher soil moisture along water courses. Examples of the riverine forest occur along the following rivers: Obuo, Kakum, Afia, Sukuma, Nemimi, Aboabo, and Ajuesu. The only floral difference from the other communities is the presence of Pseudopondias microcarpa, Ceiba pentandra, Xylopia spp and Uapaca guineensis.

- Boval vegetation: this comprises all plant communities on granitic rock outcrops with patches of shallow soil. The low herbaceous layer is made up of Sansevieria liberica and Commelina spp. The shrub layer, which reaches up to $1.5 \mathrm{~m}$ in height, is dominated by Hildergardia barteri, a tree which produces red flowers in December (around the Christmas period). The few trees found in areas of deeper soils include Hildergardia barteri, Elaeophorbia grandifolia and Sterculia tragacantha. In addition Ceiba pathandra, Albizia furruginea and Ricinodendron heudelotii are found the base of the about $100 \mathrm{~m}$ diameter circular rock outcrop near the Aboabo village community.

\subsection{Management Objectives for the Kakum Conservation Area}

National Parks and Resource Reserves in Ghana are defined in the National Wildlife Policy, which also outlines the general management objectives by which the parks and resource reserves are governed. Thereafter, specific management objectives are developed for individual parks and resource reserves depending on the unique situations and locations. Since the conservation area is made up of two different protected area categories, the management objectives have been presented separately. However, all development and management strategies in practice have been combined to meet the management aims of the entire conservation area (Wildlife Department, 1996).

\subsubsection{Objectives for Kakum National Park (KNP)}

Five long-term management objectives have been set by the national authority to give the mandate for the development and management of the park and to serve as a basis on which performance is evaluated. The outlined specific management objectives were formulated in accordance with the National Wildlife Policy and guided by the results of biological inventories and socio-economic survey that were conducted in the Kakum Conservation Area (Wildlife Department, 1996). The objectives are: 
i. To actively protect and conserve all natural resources and aesthetic features in the Kakum National Park and maintain it as a fine example of tropical rainforest ecosystem and as a source of biodiversity

ii. To exploit the park's potential for tourism and develop and maintain it based on recreational, educational and aesthetic appeal for the benefit and enjoyment of all visitors

iii. To integrate the National Park into the district and regional development processes, especially into those of the communities in the immediate vicinity of the park to ensure wider acceptance of the park's values and co-operation for the protection of the park and its resources

iv. To improve Wildlife Department's field staff welfare, discipline, motivation and capabilities

v. To increase the number of visitors to the Park and revenue generation potential of the Park.

\subsubsection{Objectives for Assin Attandanso Resource Reserve (AARR)}

The management objectives of Assin Attandanso Resource Reserve were also constituted in accordance with the National Wildlife Policy and also taking into consideration, the results of the biological inventory and socio-economic survey. The Policy prescribes general management objective for resource reserves in the country. However, the long-term objectives for Assin Attandanso include:

i. To ensure the conditions necessary for the conservation of the unique biological features within the reserve and for the sustainable utilisation of selected exploitable wildlife resources

ii. Exploiting the tourism potential of the reserve based on its game viewing, recreational, inspirational, and cultural interest

iii. Integrating the development of the reserve with that of the local communities.

The above listed objectives shall be achieved by performing specific activities explicitly designed under each of the main objectives. The following are management activities that were proposed to help achieve the management objectives of the Kakum Conservation Area (KNP and AARR):

i. Protecting the integrity of the reserve from any negative boundary alterations and inappropriate development or exploitation; 
ii. Actively improving the protection of characteristic animal species and plant communities from poaching, and other resource users;

iii. Ensuring that all park regulations pertaining to tourism are strictly enforced to avoid negative impacts and degradation of resources;

iv. Encouraging and helping local people to establish zones of cooperation around the boundary of the park wherein the spill-over of the park can be enjoyed and to establish economic wildlife related ventures;

v. Ensuring local participation in the management of the reserve by involving them in the decision making processes;

vi. Creating opportunities for local communities to benefit directly from the reserve through employment, revenue sharing of entry fees, and access to selected exploitable resources

In spite of the distinction in management objectives prescribed for the separate sections (KNP and AARR) of the conservation area, the whole area is being managed as if both sections were under the IUCN category II protected area system. This approach automatically puts the whole conservation area out of reach of the local residents, in terms of the consumptive use of resources, for the fulfilment of their subsistence livelihood needs. The following section therefore exemplifies two essential management activities in this respect.

\subsection{Management Activities in Kakum Conservation Area}

\subsubsection{Protection and Law Enforcement}

In Kakum, law enforcement takes the form of foot patrols that start from each of the eight camps situated around the conservation area. Patrol routs are planned such that the entire conservation is covered at least once a month. All illegal activities which are directly related to the killing of wildlife are considered as serious offenses and are therefore recorded. Deterrence and arresting of offenders (poachers) is the main objective of the patrol team that ensures the enforcement of laws related to the conservation of the area. Deterrence or arrests would be effective only when the patrol staff frequently visited the protected area under their jurisdiction. Hence, in order to ensure that law enforcement in protected areas in Ghana meet a minimum protection standard, and for management purposes, a minimum of 15 effective patrol man-days/staff/month was set. According to this standard, Jachmann (2008b) have noted that, for all protected areas in Ghana, the acceptable amount of illegal activity in a protected area was also set at 0.02 encounters with serious offences/ effective patrol man-day/ month. 
Figure 4.3 Efffective Patrol Man-days per Month in Kakum

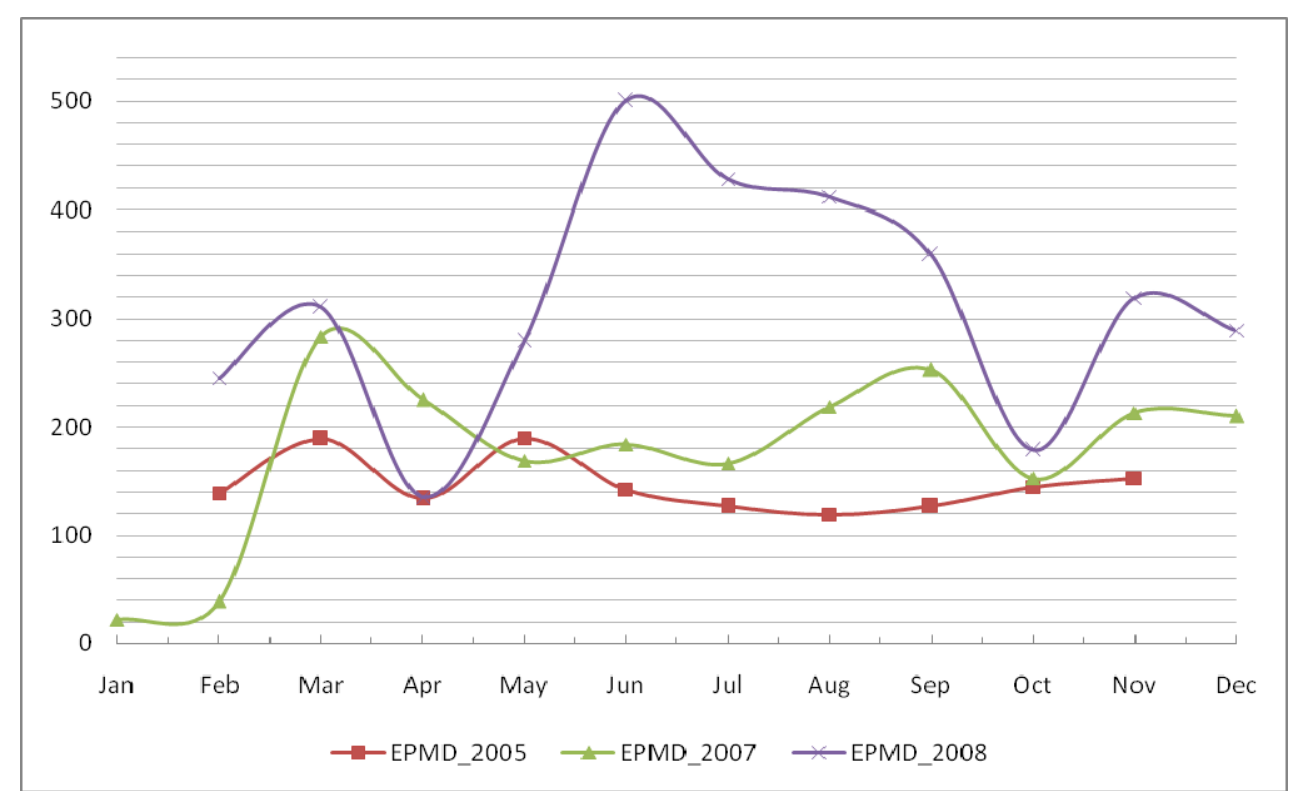

Figure 4.4 Encounter Rate with Illegal Activities in Kakum Conservation Area, 2005; 2007-2008

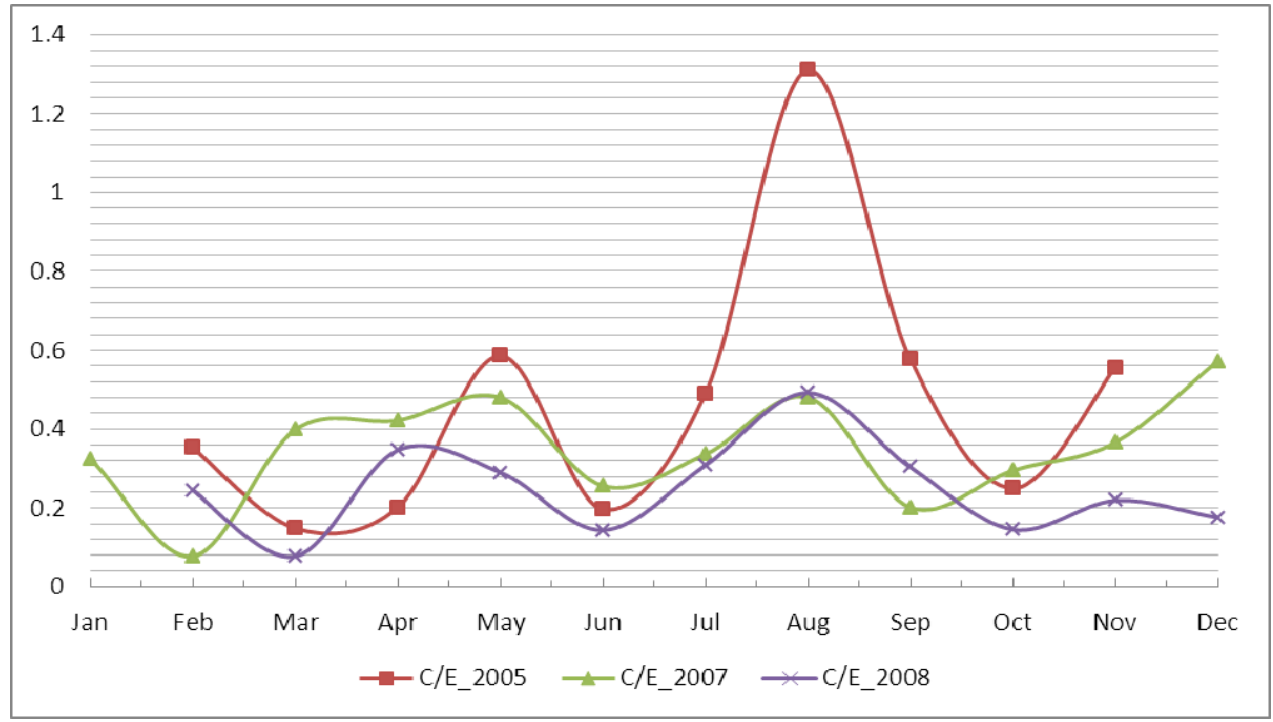

Source: Own analysis of patrol records (obtained from Wildlife Division office in Kakum)

In line with the objective of law enforcement in Kakum, an analysis of patrol records (2005 to 2008) obtained from the Wildlife Division office in Kakum indicate that the effective patrol man-days per month have consistently increased (Figure 4.3). The average effective patrol man-days have more than doubled from about 146 in 2005 to about 314 in 2008. This is expected to deter and reduce poaching activities and consequently lead to effective protection of the natural resource. From 
Figure 4.3, it can be observed that patrol efforts in 2005 were rather constant but low. The patrol efforts in 2007 gradually increased at the beginning of the year and dropped from March to a relatively constant effort levels until July and peaked again in September. In 2008, the patrol effort increased dramatically compared to the previous years. However, the effort was distinctly high between April and October, which resulted in a lower encounter rate with illegal activities in the conservation area.

In spite of the increased frequency of patrolling however, illegal activities in Kakum remain generally high, fluctuating between 0.08 and 1.31 encounters with serious offences/ effective patrol manday/month. These encounter rates were between 4 and 65 times higher than the acceptable rate. The encounter rates in 2005 ranged between 0.15 and 1.31 and that of 2007 were between 0.08 and 0.57 , while the rates for 2008 ranged between 0.08 and 0.49 (Figure 4.4). Generally, the incidence of illegal activity dropped by about $45 \%$ from an average of approximately 0.45 encounters with serious offences/ effective patrol man-day/ month in 2005 to about 0.25 in 2008.

The occurrences of illegal activities in Kakum fluctuate in terms of the intensity over the year but do not necessarily follow the same distinct pattern each year (Figure 4.4). However, illegal activities in 2005 had two peaks in May and August but were distinctly high in August, while in both 2007 and 2008, the illegal activities were particularly high in April - May and August. This indicates that illegal activities generally increase until the middle of the major raining season (April - July) and increase again until the beginning of the minor raining season. These increases coincide with the periods of low farming activities. Suggesting that particularly hunting and related activities are conducted for subsistence since most of the wildlife offences reported by the patrol staff is related to subsistence hunting (Jachmann, 2008b).

Since the law enforcement activity focus on deterrence and arrests, the cartridges and snares found and confiscated were compared for 2007 and 2008. There were distinctly more recovery of snares in March, April and August 2007, while there were more cartridges recovered in November and December (Figure 4.5). Comparatively, there were more recovery of snares than cartridges throughout 2008, with most occurring between July and September (Figure 4.6). Altogether, there were 794 incidences of serious offences in 2007, of which about $33.4 \%$ were recovered and confiscated cartridges, $42.7 \%$ snares and $12.5 \%$ gunshots. During 2008 , there were $25 \%$ cartridges, $50 \%$ snares and about $16 \%$ gunshots out of 875 incidences (Figure 4.7 ). 
Figure 4.5 A Comparison of Encounters with Cartridges and Snares in 2007

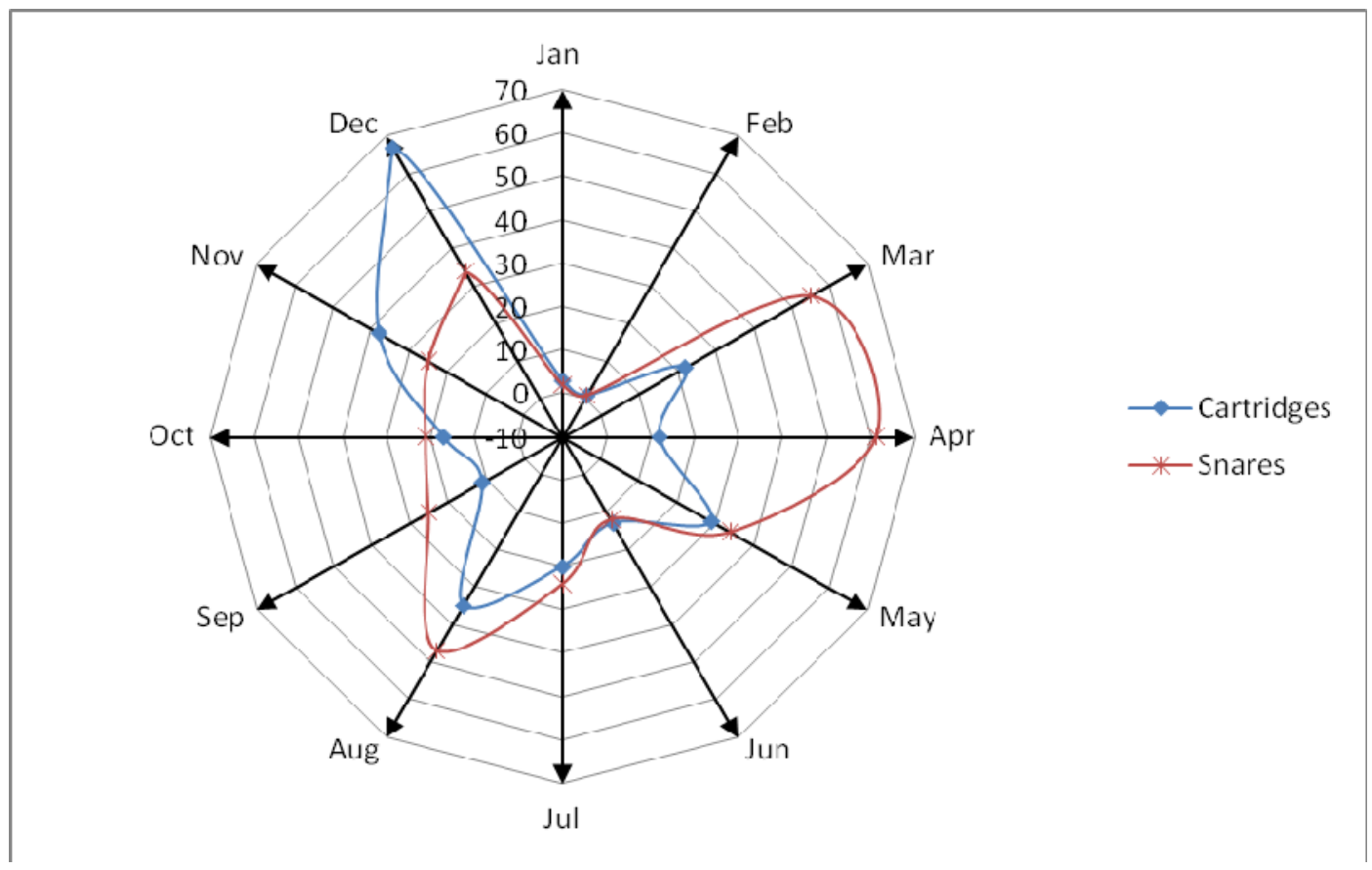

Figure 4.6 A Comparison of Encounters with Cartridges and Snares in 2008

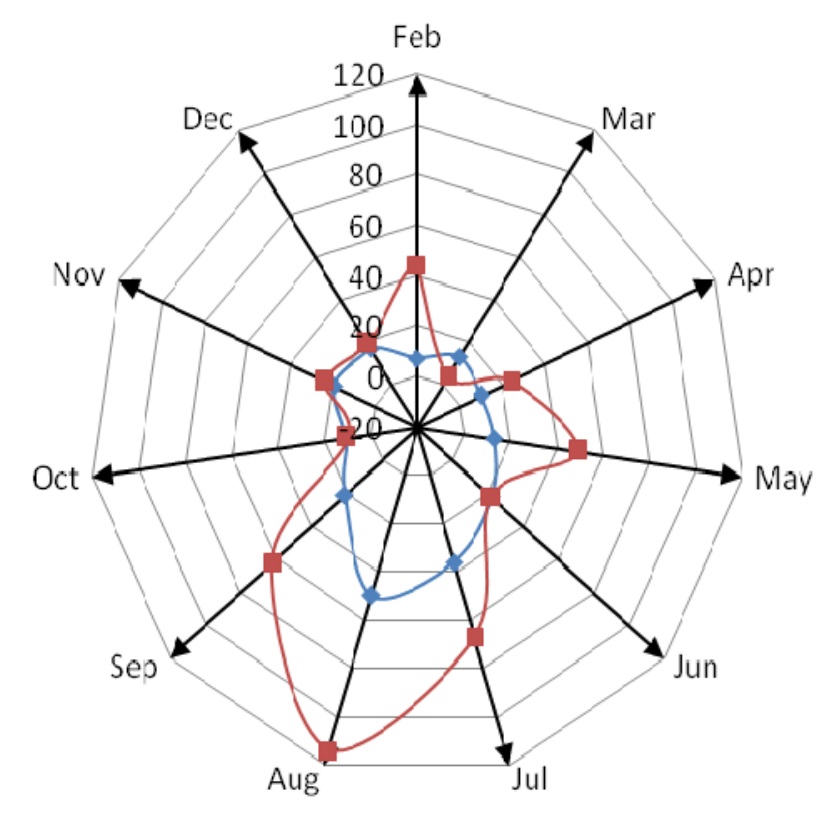

$\multimap$ Cartridges

$\rightarrow$ - Snares 
Figure 4.7 Proportions of Serious Offences (Illegal Activities) Encountered per Year

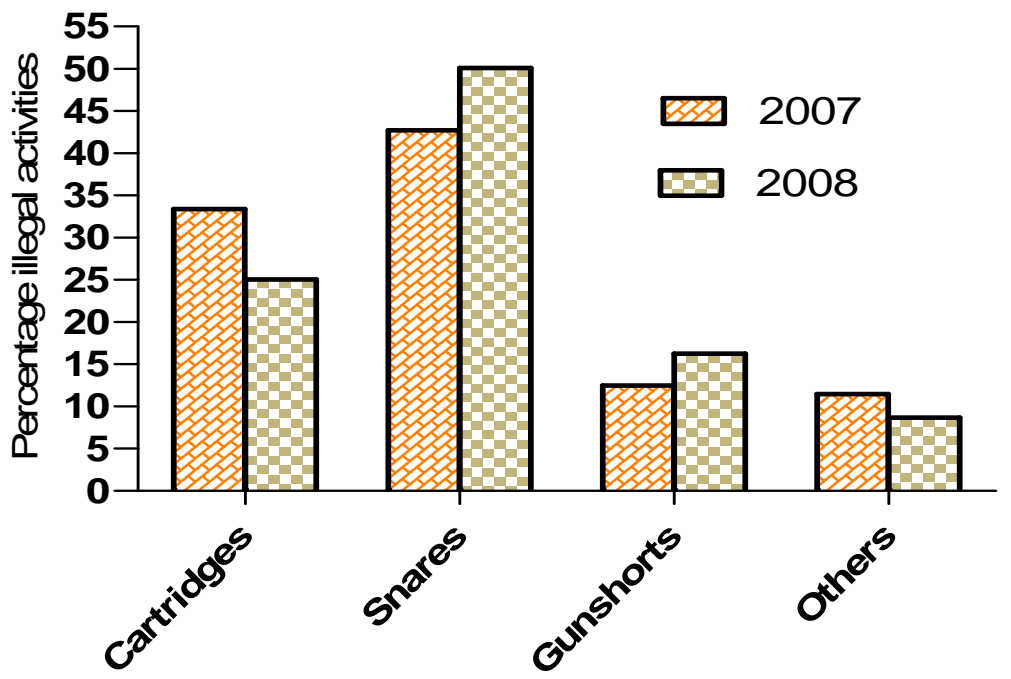

\subsubsection{Ecotourism Development in the Kakum Conservation Area}

Unsustainable exploitation of forest resources coupled with expansion of agricultural lands has lead to fragmentation of the forest cover of the country. The Kakum Conservation area is increasingly getting isolated due to extensive farming of food and cash crops around the area. As a result the conservation area was created as a means to safeguard some of the remaining patches of the Upper Guinean Forest, which is home to many species (flora and fauna) of conservation and scientific interest as described earlier in subsections 4.2.4 and 4.2.5.

To that end, it became necessary to find a sustainable means of financing the conservation of such an important ecosystem, while facilitating the economic growth of the region. Tourism development was then thought an essential means of financing and managing the protected area. Hence a $350 \mathrm{~m}$ long canopy walkway was constructed to attract visitors to the park to generate the needed revenue for conservation activities in the area. The walkway is the first of its kind in Africa. It is suspended at about $30 \mathrm{~m}$ above the forest ground, giving opportunity to view the tropical rainforest from above the tree canopy.

Other facilities such as the tree platforms at Kruwa and Mesomagor, and camping sites adjacent to the Kakum Visitor Centre were also constructed. However, these facilities are very much underutilized. Nonetheless, since 1992 when the park was officially opened to the public, tourist visitation to the park has been steadily rising and generating economic income for the administration and maintenance of the conservation area. Tourist visitation has increased from a mere 609 in 1992 
to over 96,570 with an average of 8,047 visitors per month in 2008 (available records from the Wildlife Division, January 2009). Thus far, Ghana's ecotourism programme is gradually taking momentum particularly in Kakum where a lot of donor financial and technical support has concentrated in the recent past. Kakum is currently the most patronised ecotourism site in Ghana.

\subsection{Socio-Economic Context and Livelihoods in the Kakum Conservation Area}

\subsubsection{Population}

The population of people living in the major village communities surrounding the conservation area was estimated to be about 36,200 in 1994 . However, the population is estimated to have increased to over 50,200 inhabitants, thus increasing pressure on the limited resources outside the protected zone. The overall population of the Central Region is growing at a rate of $2.1 \%$ per annum. It is the second most densely populated administrative region in the country, with a population density of 162 persons $/ \mathrm{km}^{2}$. But the average population density around forest protected areas mainly in the southern part of Ghana, where the Kakum Conservation Area is also located, is estimated to be 91 persons $/ \mathrm{km}^{2}$, whilst the average density outside the savannah protected areas is estimated as 43 persons $/ \mathrm{km}^{2}$ compared to the national average population density of 78.9 persons $/ \mathrm{km}^{2}$ and a growth rate of $2.25 \%$ per annum (Ghana Statistical Service, 2005).

Immigrants constitute about a quarter of the population in all the districts. Twifo Hemang Lower Denkyira has the highest proportion of migrants (37\%). In almost all the districts, most of the immigrants come from the Western, Greater Accra, Ashanti, Volta and the Eastern Regions of Ghana (Ghana Statistical Service, 2005).

\subsubsection{Ethnicity}

The residents of the communities are composed of the Twifo, Assin, Denkyera and Fanti (Abakrampa) ethnic groups of the Central Region of Ghana. The people of Assin are believed to have migrated from the Ashanti Region. However before the Assins settled in their present location, the area was inhabited by an indigenous group of people called the Etsi, but they are mostly dominated by the Assins ${ }^{8}$.

\footnotetext{
${ }^{8}$ Information gathered from Okyeame Ampofo, an elder of the Kruwa village through personal communication.
} 
In addition to the major ethnic groups, most of the communities around the conservation area are also inhabited by people from other ethnic groups in the country. They have migrated into the area to take advantage of the fertile land and favourable climate for farming. These migrants include the Ewes, Krobos, Ga-Adangbes, Akuapims, Fantis and in isolated cases Frafras and Dagatis from Northern Ghana (Wildlife Department, 1996; Agyare, 1995). This is consistent with the regions of origin of the immigrants as stated in section 4.5.1.

\subsubsection{Settlement Pattern}

A survey conducted by Agyare (1995) indicated that there are over 52 major village communities locate around the Kakum Conservation. Two settlements patterns, namely, permanent and temporary, are identified in the communities. The permanent settlements are usually found in the indigenous and old settler communities. These are usually cluster settlement type and the living rooms are built with mud and thatch. Others are built with brick and cement blocks. The temporary settlements are of the relatively younger settler farming communities. They are mainly built with wattle and daub with thatch roofing. The settlement patterns in these communities is either the cluster type where people live in conglomerate of houses or the core type where the community head and the close relatives stay detached from the other community members. The other members of such community are scattered with each family putting up their building close to their farmland.

\subsubsection{Infrastructure and Services}

\subsubsection{Roads}

Most of the communities around the conservation area are linked with roads and a network of footpaths. However, not all the communities are easily accessible due to the deplorable conditions of some of the roads. Transportation to the communities from the main roads is mostly limited to the so called market days. This is usually a day in the week that the village community has set aside to stay away from farming activities and sell their farm products.

The deplorable nature of some of the roads is a major concern to the local people. Most of the farm products get wasted because of the farmers' inability to transport them at the right time to the main marketing centres which are generally far from the village communities (Wildlife Department, 1996). 


\subsubsection{Water Source}

The supply of water, both in quantity and quality, have considerably improved in some of the communities as a result of the provision of hand pump fitted bore holes by a number of nongovernmental organisations operating in the area (Wildlife Department, 1996). However, some of the communities still use water from nearby streams and own hand dug wells.

\subsubsection{Educational Facilities}

Education facilities for effective teaching and learning in the conservation area are of concern. It is reported that with the exception of very few, all the communities have some facilities (primary schools up to class 6) for basic education of their children. On the other hand, it is only a few of the major communities that have Junior Secondary Schools to cater for children's education after the basic level. This could explain why there is a high illiteracy among the adult population (Wildlife Department, 1996; Agyare, 1995).

\subsubsection{Sanitation and Health Facilities}

Sanitation in the communities is generally poor. Toilet facilities provided in some of the communities are open latrines and usually situated at the outskirts of the communities, while others are close to individual homes, thus exposing the community to risk of infection should there be an epidemic outbreak.

The distribution of health facilities does not favour the large rural majority in the Central Region. Health delivery in communities within the Twifo Hemang Lower Denkyira District is very poor, with as high as 125,007 patients to a doctor compared to the Assin District of 30,407 patients to a doctor (Ghana Health Services, 2007). Similarly, the nurse/patient ratio in Twifo Hemang Lower Denkyira is 2,976 patients to a nurse while it is 2,644 patients to a nurse in the Assin District (Central Regional Health Services, 2007). Health post facilities are located in relatively bigger communities which are far from the people living close to the conservation area. However, traditional health practitioners or herbalists are found in most of the communities and therefore depend on them for common ailments. 


\subsubsection{Local Economy}

Agriculture is the mainstay of the people living in the communities around the conservation area. Both subsistence and commercial types of agriculture are the predominant activities in the communities surrounding the reserve, where the members of the family serve as the basic labour force. Hence agricultural production in the area is generally in small scale. The major food crops cultivated include plantain, cassava, maize, cocoyam, and yam among others. The cash crops cultivated in the area are mainly cocoa, oil palm, coffee, citrus and coconuts. Cocoa production is concentrated in Assin, Twifo-Hemang-Lower Denkyira and Upper Denkyira districts, while oil palm production is mainly in Assin and Twifo-Hemang-Lower Denkyira in comparison to other administrative districts in the Region. Both food and cash crops are sold on the local market which forms the basis of the income of the local people. The farming system employed is largely rain fed mixed cropping on shifting cultivation basis. Farming by the local people is an all year round economic activity.

Livestock raising is a common feature as a supplementary source of income. Small scale sheep and goat rearing is mostly done for sale. Likewise, domestic fowls and other birds are kept for and used as supplementary source of protein. They are also sold in times of financial difficulty. Other economic activities include the production of palm oil and distillation of alcoholic beverage. The palm oil production is mostly done by women to supplement their household income. On the other hand, the production of alcoholic beverage from fermented palm wine is undertaken mostly by men. 


\subsection{References}

Adams, J. S. and MacShane, T. O. 1996. Myth of Wild Africa: Conservation without Illusion. Los Angeles: University of California Press.

Adu-Nsiah, M. 1996. The Vegetation of Kakum Conservation Area (KCA). In Ghana Wildlife Department, 1996. Facing the Storm - Five years of research in and around Kakum National Park, Ghana. Kakum Conservation Area Research Colloquium. Jan 9-12, 1996. Ghana Wildlife Department, Accra.

Agyare, A. K. 1995. Socio-Economic Perspective of Kakum National Park and Assin Attandanso Resource Reserve. Unpublished Report. Ghana Wildlife Department. Accra.

Birdlife International 2002. Important Bird Areas and potential Ramsar Sites in Africa. http://www.birdlife.org/action/change/ramsar/ibas ramsar africa/Ghana.pdf (2011)

Central Regional Health Services. 2007. Central Regional Health Services Administration Report. Ghana

Critical Ecosystem Partnership Fund, 2000. Ecosystem Profile. Upper Guinean Forest Ecosystem of the Guinean Forests of West Africa Biodiversity Hotspot. Washington D.C.: CEPF Secretariat, Conservation International

Earth Trends. 2003. Biodiversity and Protected Areas - Ghana. Country Profiles. (http://earthtrends.wri.org/pdf library/country profiles/bio cou 288.pdf) (12.10.2010)

EPA. 2009. Ecological Mapping of the Songor Ramsar site. Final Report. Environmental Protection Agency, Accra. Ghana

Ghana Health Services. 2007. Annual Report. Accra, Ghana

Ghana Statistical Service. 2005. 2000 Population and housing census. Analysis of district sata and implications for planning. Accra: Ghana Statistical Service

Hawthorne, W. D. and Abu-Juam, M. 1993. Forest Protection in Ghana - Report FIMP. Planning Branch, Forestry Department. Kumasi. 203pp

IUCN. 1994. Guidelines for Protected Area Management Categories. CNPPA with the assistance of WCMC. IUCN: Gland, Switzerland and Cambridge, UK.

Jachmann, H. 2008. Monitoring law-enforcement performance in nine protected areas in Ghana. Biological Conservation 141: 89 - 99

Jachmann, H. 2008. Illegal wildlife use and protected area management in Ghana. Biological Conservation 141:1906 - 1918

Kotey, E.N.A., Francois, J., Owusu, J.G.K., Yeboah, R., Amanor, K.S. and Antwi, L. 1998. Falling into Place. Policy that works for forests and people series no. 4. International Institute for Environment and Development, London. 
Larsen, T. B. 1994. Diopetes kakumi, a new hairstreak from Kakum National Park, Ghana. Tropical Lepidoptera, 5:83-84.

McNeely, J. A. (Ed). 1993. Parks for Life: Report of the IVth World Congress on National Parks and Protected Areas. INCN: Gland.

Ministry of Lands and Forestry. 1994. Forest and Wildlife Policy. Accra, Ghana

Ministry of Tourism. 1996. National Tourism Development Plan for Ghana 1996 - 2010. Integrated Tourism Development Programme GHA/92/013 - Final Report. Ministry of Tourism, United Nations Development Programme, World Tourism Organisation. Accra: Ghana

Murphree, Michael J. 2005. CREMA Review. Wildlife Division Support Project Report No. 56. Accra: Wildlife Division, Forestry Commission.

UICN/PACO 2010. Parks and reserves of Ghana: Management effectiveness assessment of protected areas. Ouagadougou, BF: UICN/PACO.

West, P., Igoe, J., and Brockington, D. 2006. Parks and People: The Social Impact of Protected Areas. Annu. Rev. Anthropol. 35:251-77 (http://www.cerium.ca/IMG/pdf/Parks_and_people.pdf) $(10.01 .2011)$

Wildlife Department. 1996. The Management Plan for Kakum Natiojnal Park and Assin Attandanso Resource Reserve. Wildlife Department, Accra, Ghana.

Wildlife Department. 1997. Wildlife Development Plan 1998 - 2003. Ecotourism Vol. 5. Protected Area Management and Wildlife Conservation Project. Wildlife Department, Accra, Ghana

World Bank. 2006. Ghana Country Environmental Analysis. Report No: 36985-GH September 06, 2006 Environmentally and Socially Sustainable Development Department (AFTSD) Africa Region. 


\section{Chapter Five: Local Community's Needs and Perceptions Concerning Kakum Conservation Area and its Management - Challenges and Opportunities for Integration}

\subsection{Introduction}

The establishment of protected areas has often followed the protectionist approach and the concept of wilderness. According to Gómez-Pompa and Kaus (1992), the concept of protected areas emanated mostly from more urban perception. That is a perception of people who are far removed from the natural environment they depend upon. This perception and the push for protected area establishment have thus virtually imposed a nature-culture dichotomy on places and people (in many developing countries particularly in Africa) where such kind of distinction between nature and culture did not exist before. Such concept and approach however, does not recognise the importance and significance of local land-use practices and management which have played a role in sustaining and protecting biodiversity. The protectionist approach thrives on the notion that protected areas can only be maintained without local or resident people and this has long influenced conservation policy (Manning, 1989; Gómez-Pompa and Kaus, 1992). Conservationists, for example, see the aesthetic and biological value of a rainforest, but they neglect the local people who live in or adjacent to the forest in question. Local people are therefore actively and willingly excluded from any form of use, often leaving it to the visitor and tourist if the area is being promoted as a tourist destination.

The number and surface area of protected areas has increased worldwide, affirming the fact that protected area establishment as a means to safeguard biodiversity has gained credence in the world of nature conservation. West, et. al. (2006) noted that, per official records of IUCN as of 2005, there were over 105,000 protected areas across the world, covering $20.3-21.5$ million $\mathrm{km}^{2}$. The protected terrestrial ecosystem covers about 16.8 million $\mathrm{km}^{2}$ or $11 \%$ of the world's land surface. The authors further estimated that $4.3 \%$ of the global terrestrial surfaces are assigned to one of the IUCN protected area management categories which can impose restrictions on human use and occupancy.

In Ghana, there are a total of 321 protected areas including both the unclassified and those classified into different IUCN categories, covering about 15.46\% (see section 4.3; Figure 4.3) of the terrestrial surface of the country (Earth Trends, 2003). When protected areas are established, local communities living in or adjacent to these areas often have to adjust their livelihoods and lifestyle, as natural resources they were formerly using become inaccessible. Conflicts can then ensue due to restrictions on the use of natural resource, as well as in some cases, forceful evictions or other unfavourable relations with protected area staff, lack of resident participation in conservation, and often, the absence of open communication (Hough, 1988). Conflicts are usually manifested by a 
range of behaviour; from local expressions of anti-protected area sentiments to intentional burning and poaching in the protected areas and threats or actual bodily harm to protected area staff (see Ite, 1996; Brandon, et. al., 1998; Tello, et. al., 1998; Peters, 1999).

It is "common knowledge" that people living in and around protected areas do influence the chance to meet conservation objectives in a protected area. Hence, conservation paradigm has moved towards more community or local people's involvement during the last three decades (Chapin, 2004; Berkes, 2007). Many authors, e.g. Thakadu, 2005; Spiteri and Nepal, 2006; Horwich and Lyon, 2007, support community involvement in conservation as they demonstrate that incorporating local interests is critical to the success of protected area management. Also, researchers (like: da Silva, 2004; Spiteri and Nepal, 2006; Horwich and Lyon, 2007; Haller, et. al., 2008) contend that participatory conservation approaches have greater potential for generating a legitimate conservation process that is backed by the people that are most affected, and can increase compliance and reduce conflicts generated from resource use restrictions (Barrow and Murphree, 2001; Brechin, et. al., 2002; Berkes, 2007).

Local community involvement in conservation efforts varies widely, reflecting a continuum from protectionist approaches typically run by central governments, to programmes driven completely by local communities themselves (da Silva, 2004). At one end of this spectrum are 'instructive' management frameworks, in which governments or other external agencies control the management process and where local communities are only informed about management decisions. In the middle of the continuum are 'co-operative' or 'collaborative' processes, in which management result from an equal partnership between local communities and external agencies. At the other end of the continuum are 'informative' practices, where communities control the management process and report their actions to the government (da Silva, 2004).

Good management practice, according to Smith, et. al. (2003), is the key factor in strengthening the effectiveness of protected areas. Dearden, et. al. (2005) goes further to state that the quality of management is actually based on many factors, including the involvement of key stakeholders in the process of decision-making. In spite of this and the increasing rhetoric in favour of local people's participation in natural resources management, demonstrated in the 1994 Forest and Wildlife Policy, forest and wildlife resources management in Ghana still follows mostly the protectionist approach. The Wildlife Department (WD) of the Forestry Commission manages all wildlife protected areas and only informs the local people or communities of management actions where necessary. Hence, an 
attempt to involve communities in any conservation process would require incorporating their needs and interests in the management objectives of the protected area in question.

Thus, the following part of this study examines the perceptions, views and concerns of local people along thematic lines on issues of nature conservation and management within the Kakum Conservation Area in Ghana. The study acknowledges the growing appreciation that natural resource management might be more effective and more beneficial to local people if their interests are better incorporated into decision-making related to biodiversity conservation (Toledo, 2001; Nepal, 2002). However, to achieve this requires decision-makers to acknowledge and understand the concerns and interests of the local people. The study intends to underscore these interests, and discuss the accompanied challenges and opportunities in order to help better integrate these local priorities and wishes into conservation activities in the study area. This would make conservation easier to implement and also significantly more effective.

\subsection{Methodology: Data Collection and Analysis}

The data on communities was collected using survey questionnaire (Appendix 1), semi-structured interviews and group discussions (Appendix 3). The data collection at the community level was aimed at gathering information on livelihood activities, involvement in conservation initiatives, benefits derived from the conservation area, traditional institutions and authority, and perceived costs and benefits of the protected area. To achieve this, a survey of 141 household heads and or representatives was conducted in eight village communities within the Kakum Conservation Area. In addition, community leaders were interviewed and group discussions were also conducted. Snowball sampling procedure was used to interview community leaders and chiefs. These approaches were adopted to increase the reliability of the information gathered from the local resident people. Further, officials of the Wildlife Division, directly responsible for managing the conservation area were also interviewed (see Appendix 4) on varying themes concerning: motivation for KCA's establishment, general conservation activities, livelihood of local people and local community involvement in their management operations. Other sources were also used to compliment the field data in order to put the findings in context. The survey data were subsequently coded and descriptive analysis was applied to present the result in tables and graphs using the GraphPad Prism 5 software, while the analysis and graphical presentation of the patrol data was prepared with Microsoft Excel. 


\subsection{Results and Discussions}

\subsubsection{Livelihood Activities of Local People}

The communities bordering the Kakum Conservation Area are basically village communities. All the eight village communities sampled for the study are predominantly farming communities. Inhabitants of these communities engage in cash and food crop farming as the main livelihood activity and they supplement this with collection of non-timber forest products (NTFPs), hunting, domestic poultry and life stock rearing, small scale agricultural processing and petty-trading (Figure 5.1; Table 5.1). NTFPs such as medicinal plants, snails, mushrooms, cane, raffia, construction materials, firewood, among others were collected during farming and off-farming seasons.

Table 5.1 Livelihood Activities of Respondents' in the Local Communities

\begin{tabular}{|l|l|l|l|l|l|}
\hline Livelihood Activity & Products & \multicolumn{2}{l|}{$\begin{array}{l}\text { Before establish- } \\
\text { ment of KCA }\end{array}$} & \multicolumn{2}{l|}{$\begin{array}{l}\text { After establish- } \\
\text { ment of KCA }\end{array}$} \\
\cline { 3 - 6 } & & $\mathbf{n}$ & $\mathbf{\%}$ & $\mathbf{n}$ & $\mathbf{n}$ \\
\hline Farming & Food and cash crops & 137 & 97.2 & 140 & 99.3 \\
\hline NTFP collection/sale & Snail, mushroom, cane, herbs, etc & 127 & 90.1 & 30 & 21.3 \\
\hline Domestic animal rearing & Chicken, goat, sheep, etc & 140 & 99.3 & 133 & 94.3 \\
\hline Petty trading & Food \& vegetables, cosmetics, etc & 28 & 19.9 & 55 & 39.0 \\
\hline $\begin{array}{l}\text { Small scale agro- } \\
\text { processing }\end{array}$ & $\begin{array}{l}\text { Cassava processing, palm oil } \\
\text { production, alcohol distillation }\end{array}$ & 33 & 23.4 & 20 & 14.2 \\
\hline Hunting/trap setting & Rodents (rats and grasscutter) & 40 & 28.4 & 8 & 5.7 \\
\hline
\end{tabular}

Source: Community survey data (2009); N=141 (NB: respondents' households are engaged in multiple livelihood activities in addition to farming)

Figure 5.1 Comparison of Livelihood Activities in KCA

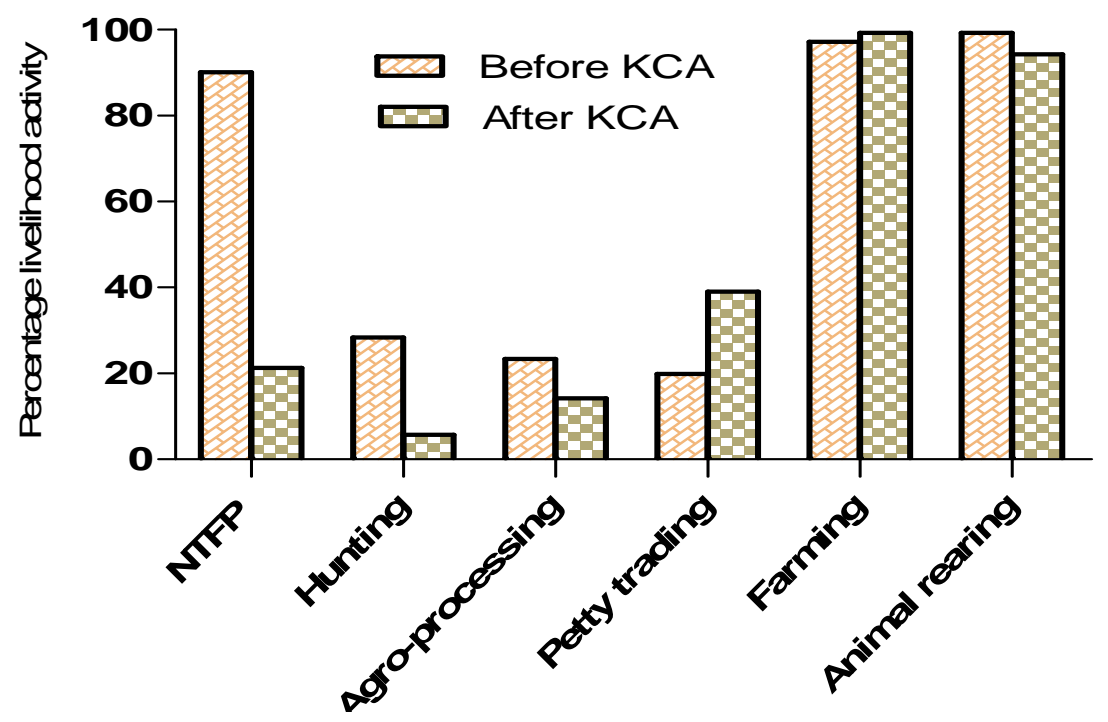


According to the respondents (both in the group discussions and interviews with community leaders) collection of NTFPs and hunting were not completely restricted in former time. Individuals could hunt with light weapons and set animal traps for domestic consumption to satisfy their protein needs. The collection of construction materials to build, maintain or renovate their houses was always and is still today of utmost importance. But with the creation and enforcement of the protected area, to quote one Wildlife Official, "the right of access and use of forest resources was stripped overnight". Local people now depend on the scarce and depleted resource outside the protected zone, on their individual farms and fallow lands around the village communities. The enforcement of protection has drastically reduced the number of people that would potentially collect NTFPs either for domestic consuption or sale (Table 5.1). Such kind of access restrictions usually force a higher number of people to rely on a smaller amount of resources, which potentially could lead to local over exploitation. The rural poor often have no alternatives to NTFPs. Consequently a common complaint about forest conservation amongst the local communities included the loss of access to construction materials, and bush meat for local consumption.

Figure 5.2 Land Ownership Among Respondents per Community

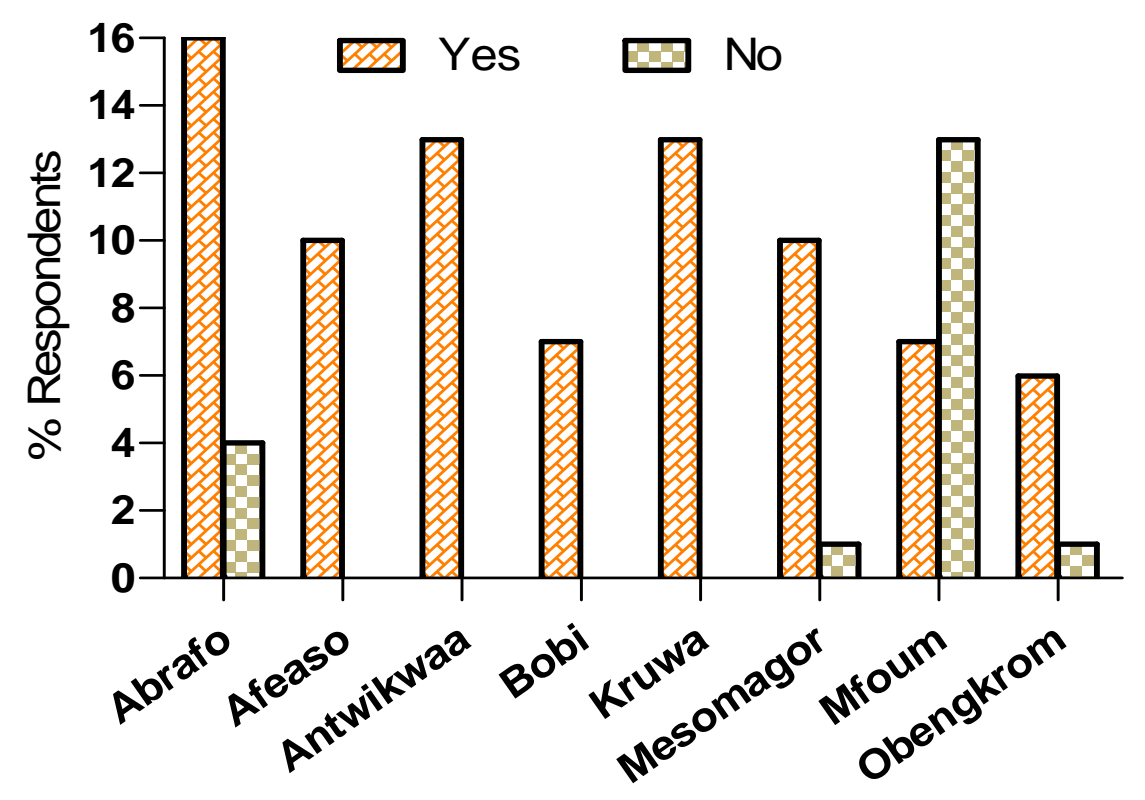

Source: Community survey data (2009)

The collection of NTFPs for subsistence livelihoods as pertains in most rural or village communities in Ghana and as observed around the KCA has not caused resource depletion nor did it amount to forest fragmentation and susbsquent habitat loss for wildlife species. The extensive conversion of 
forest lands into agricultural lands is however of major concern. The econony of the local people is land based and almost every family or household around the conservation area owns some parcel of land (see Figure 5.2) which are acquired through various customary arrangements purposely for farming (Figure 5.1; Table 5.1). The villages are situated in direct neighbourhood to the protected area and some individuals even shared land boarders with it. Hence, there is no buffer zone but a very sharp gradient of vegetation from high forest in the PA to cash or food crop farm lands. This was reproted to be the case around the entire PA. This linear borders without gradation do provoke repeated trouble because the farmlands are a potential attraction for some wildlife species, particularly the forest elephants, who stray and raid local people's food and cash crop farms.

Other concerns raised by the administrative staff is the increasing commercialisation of NTFPs, particularly wildlife (bushmeat). Discussions in the communities and with Wildlife Officials confirmed that hunting has been taken up as a commercial activity for some local people who hunt in groups with light weapons and assisted by hunting dogs. What this study could not establish is whether there are such group hunters in the sampled communities. Officials of the Wildlife Division indicated that hunting is now turned into a secrete business and it is difficult to track the people behind. The patrol teams of the Wildlife Divison have been making arrests of poachers but the end to this challenge does not seem to be near because bushmeat, is a special delicacy in Ghana and most African countries and therefore has a ready market. Therefore, the commercialisation of bushmeat, coupled with the fact that hunting has tuned into a secret venture can no longer guarantee sustainability but might lead to detrimental effects on animal populations. Hence, the Wildlife Officer in-charge of law enforcement (Wiafe, 2009 per com.) explained that they currently use the militant approach, that is arrests and deterrent, to enforce conservation of the resources (see Section 4.4.1).

\subsubsection{Perceptions of Local People Concerning the Impact of Kakum Conservation Area}

In principle, the local people are reasonable and complaisant concerning the usefulness of the conservation area. However, as much as there is a general acceptance of the creation of the conservation area, they are not in agreement with the level of impact it has on their communities. According to the survey results, about two-thirds (67.4\%) of the respondents agreed with statement 1: protective measures at KCA have resulted in an increase in wildlife populations (Table 5.2), while $32.6 \%$ disagreed $(n=141)$. The logistic regression indicated that gender and ownership of land were influencing their responses significantly $\left(\chi^{2}=33.05, p<0.0001\right)$. The results indicated that female respondents more likely perceived an increase in the wildlife populations. Likewise did respondents with small land size ownership. Older respondents' probably had a better judgement due to their 
Table 5.2 Local Peoples' Perceptions of the Conservation Effects at Kakum Conservation Area (KCA)

\begin{tabular}{|c|c|c|c|c|c|c|c|c|c|c|c|c|c|c|}
\hline \multirow{2}{*}{$\begin{array}{l}\text { State- } \\
\text { ment }^{\text {a }}\end{array}$} & \multirow[t]{2}{*}{ Answers } & \multicolumn{3}{|c|}{ Community Cluster $^{\text {b }}$} & \multirow[t]{2}{*}{ Total (\%) } & \multicolumn{5}{|c|}{ Variable $^{c}$ in the equation } & \multicolumn{4}{|c|}{ Final logistic model } \\
\hline & & $A$ & $\mathrm{~B}$ & $\mathrm{C}$ & & & $B$ & s.e. & Wald & $p$ value & $\operatorname{Exp}(B)$ & $\chi^{2}$ & $p$ value & $R^{2}$ \\
\hline \multirow[t]{8}{*}{1} & agree & 42 & 25 & 28 & $95(67.4 \%)$ & $\operatorname{sex}$ & 1.102 & 0.395 & 7.785 & 0.005 & 3.011 & 33.053 & 0.000 & 0.283 \\
\hline & & & & & & educ & 0.102 & 0.470 & 0.047 & 0.828 & 1.107 & & & \\
\hline & & & & & & Age & 1.903 & 1.148 & 2.746 & 0.098 & 6.706 & & & \\
\hline & & & & & & Age & 1.396 & 1.174 & 1.413 & 0.235 & 4.037 & & & \\
\hline & disagree & 14 & 17 & 15 & $46(32.6 \%)$ & Comty & -0.352 & 0.435 & 0.657 & 0.418 & 0.703 & & & \\
\hline & & & & & & Comty & 0.740 & 0.462 & 2.561 & 0.012 & 2.096 & & & \\
\hline & & & & & & land & 2.140 & 0.838 & 6.527 & 0.011 & 8.499 & & & \\
\hline & & & & & & damage & 0.749 & 0.402 & 3.465 & 0.063 & 2.114 & & & \\
\hline \multirow[t]{7}{*}{2} & agree & 34 & 23 & 26 & $83(58.9 \%)$ & sex & 3.143 & 0.523 & 36.111 & 0.000 & 23.171 & 70.790 & 0.000 & 0.527 \\
\hline & & & & & & educ & 0.315 & 0.550 & 0.327 & 0.567 & 1.370 & & & \\
\hline & & & & & & Age & -2.419 & 1.339 & 3.264 & 0.071 & 0.089 & & & \\
\hline & disagree & 22 & 19 & 17 & $58(41.1 \%)$ & Age & -2.992 & 1.376 & 4.727 & 0.030 & 0.050 & & & \\
\hline & & & & & & Comty & 0.384 & 0.625 & 0.378 & 0.538 & 1.468 & & & \\
\hline & & & & & & Comty & 1.703 & 0.696 & 5.983 & 0.014 & 5.489 & & & \\
\hline & & & & & & land & 1.004 & 0.724 & 1.925 & 0.165 & 2.730 & & & \\
\hline \multirow[t]{6}{*}{3} & agree & 28 & 18 & 16 & $62(44.0 \%)$ & sex & -1.180 & 0.393 & 9.008 & 0.003 & 0.307 & 27.578 & 0.001 & 0.238 \\
\hline & & & & & & educ & -0.062 & 0.446 & 0.019 & 0.889 & 0.940 & & & \\
\hline & & & & & & Age & -0.388 & 0.990 & 0.154 & 0.695 & 0.678 & & & \\
\hline & disagree & 28 & 24 & 27 & $79(56.0 \%)$ & Comty & 1.072 & 0.533 & 4.050 & 0.044 & 2.922 & & & \\
\hline & & & & & & Comty & -0.830 & 0.517 & 2.571 & 0.109 & 0.436 & & & \\
\hline & & & & & & damage & -0.330 & 0.385 & 0.731 & 0.392 & 0.719 & & & \\
\hline
\end{tabular}

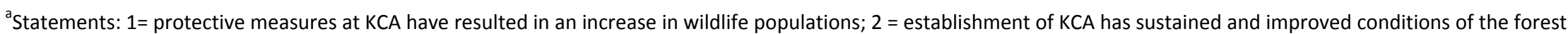
vegetation; 3 = establishment of KCA has improved local rainfall

${ }^{b}$ community cluster: $A=\left(\right.$ Abrafo; Mfuom), B = (Afeaso; Antwikwaa; Bobi), C = (Mesomagor; Kruwa; Obengkrom). ${ }^{C}$ Variable: sex = gender of respondent,

educ $=$ education level, Age $=$ age group of respondent, Comty $=$ community, land $=$ ownership of land 
knowledge of the historical situation. The younger people, through the discussions, were of the opinion that since hunting and consumptive use of natural resources in the conservation area had been officially banned, it was to be expected that the wildlife populations would increase. The conservation area was considered a means to forestall the dwindling of forest resources and consequently to protect the habitat of wildlife species. Again, respondents from community cluster two (made up of Afeaso, Antwikwaa, and Bobi) significantly $(p=0.012)$ agreed to this assertion as compared with community cluster 3 (Kruwa, Mesomagor and Obengkrom).

The reserve was further perceived as protecting the watersheds or the important rivers and streams which are the sources of water for all the adjacent communities. During the group discussions, some participants alluded that the conservation area was responsible for the favourable local area rainfalls and the relatively good weather conditions. Their assertion was based on the premise that the forest vegetation did improve. When asked, about 59\% of the household respondents agreed with statement 2: establishment of KCA has sustained and improved conditions of the forest vegetation. Gender, age and community affiliation determined the perception of improved forest resources $\left(\chi^{2}=\right.$ $70.79, p<0.0001$ ) (Table 5.2). The regression analysis indicates that in particular, community cluster two and age group (30 - 50) claimed there was much improvement of the forest resources due to the enforcement of conservation measures. However, more than half $(56 \%)$ of the respondents doubted that the reliable local area rainfall pattern (statement 3: establishment of KCA has improved local rainfall) was due to conservation only $\left(\chi^{2}=27.6, p<0.0001\right)$. Especially male respondents from community cluster one (Abrafo and Mfuom) significantly disagreed to the perception of improved local area rainfall pattern (Table 5.2). According to the local people, the reserve currently also serves as repository of medicinal plants and therefore protecting the resources is vital in order to preserve the benefits for future generations. The foregoing does not preclude that local people also perceive some difficulties and losses endured as a result of the conservation area.

As for perceived losses, the designation of the KCA as a protected zone implied losing a greater part of the traditional hunting area particularly for the locals of Kruwa village community. In the same way, it also reduced the area of community land which potentially could have been converted and utilised for traditional farming and other activities. Community leaders indicated that no royalties were paid to land owners, compared to what pertains when a land is used for timber extraction activity. Mention was also made concerning the difficulties that strict protection of the area has brought in terms of roofing and maintaining houses and collecting NTFPs. More than three quarters 109 (77.3\%) of respondents stressed that the creation of the conservation area has worsened access 
Table 5.3 Local Peoples' Attitude towards Conservation in Kakum Conservation Area

\begin{tabular}{|c|c|c|c|c|c|c|c|c|c|c|c|c|c|c|}
\hline \multirow{2}{*}{$\begin{array}{l}\text { State- } \\
\text { ment }^{a}\end{array}$} & \multirow[t]{2}{*}{ Answer } & \multicolumn{3}{|c|}{ Community Cluster $^{\mathrm{b}}$} & \multirow[t]{2}{*}{ Total (\%) } & \multicolumn{3}{|c|}{ Variable $^{c}$ in the equation } & \multicolumn{6}{|c|}{ Final logistic model } \\
\hline & & $\bar{A}$ & $B$ & $\mathrm{C}$ & & & $B$ & s.e. & Wald & $p$ value & $\operatorname{Exp}(B)$ & $\chi^{2}$ & $p$ value & $R^{2}$ \\
\hline \multirow[t]{3}{*}{4} & approve & 29 & 8 & 9 & $46(32.6 \%)$ & Comty & -1.056 & 0.527 & 4.022 & 0.045 & 0.348 & 21.625 & 0.000 & 0.199 \\
\hline & & & & & & Comty & -1.014 & 0.502 & 4.081 & 0.043 & 0.363 & & & \\
\hline & disapprove & 26 & 34 & 34 & $94(66.7 \%)$ & land & 1.235 & 0.540 & 5.231 & 0.022 & 3.437 & & & \\
\hline
\end{tabular}

statements: 4 = would you approve of increasing the size of the conservation area in order to create a buffer zone?

${ }^{b}$ community cluster: $A=\left(\right.$ Abrafo; Mfuom), B = (Afeaso; Antwikwaa; Bobi), C = (Mesomagor; Kruwa; Obengkrom). ${ }^{c}$ Variable: sex = Comty = community, land = ownership of land. 
to NTFPs making life difficult for most residents. The situation has virtually eroded some aspects of traditional handicraft (e.g. basket weaving) as confirmed by $99(70.2 \%)$ of respondents. This has led to the loss of livelihood for particularly out-of-school youth who are compelled to move to nearby towns and cities in search of non-existent jobs. Further, over two thirds $95(67.4 \%)$ of the respondents also attributed crop damage to the creation of the conservation area and the subsequent use restrictions. These respondents had their farms (or those of friends and relatives) destroyed by wild animals, particularly the forest elephants. The respondents advocated that problem animals should be eliminated. However, Skonhoft (1998) confirms that anti-poaching laws forbid such action. There were also claims that in the past, human activities had kept the wild animals within the confines of the main forested area, hence there were fewer incidences of wildlifecrop damage as compared to the present.

With respect to the reported increase in wildlife crop damage, respondents were asked to give their opinion to statement/question 4: would you approve of increasing the size of the conservation area in order to create a buffer zone? However, 94 (66.7\%) disapproved (Table 5.3) because they feared that it will only be a strategy to claim additional community lands without any compensation. Community of residence and ownership of land were the main factors that influenced this attitude in the logistic regression analysis $\left(\chi^{2}=21.6, p<0.0001\right)$. Most respondents wanted that part of the conservation area, within its existing boundaries, be converted into a form of controlled consumptive use zone thereby serving as a buffer zone.

\subsubsection{Local Peoples' Appreciation of Kakum Conservation Area}

In spite of restrictions on access and use of resources in the conservation area, the majority of the respondents ascribed various values to emphasis why they thought the area was of special importance (Table 5.4). The most important values are: the worth as repository of NTFPs, the mere existence of the forest, and services provided by the ecosystem like regular rainfall and protection of water sources. Important notes emanating from the group discussions indicate that the resident local people still ascribe value to the conservation area as also indicated in the survey result (Table 5.4). They explained that the protected area harbours plant and animal species that are of direct subsistence value to them. They believed that even though they were not allowed to enter the protected area, with time when the animal populations increase within the protected area, these animals would find their way out to neighbouring farms to be hunted. Furthermore, they believed that the continuous existence of the forest was responsible for the favourable microclimate that is facilitating their food and cash crop farming. Again, they claimed it provided opportunity for 
education, both directly and indirectly, either offering educational experience as one takes a walk through the forest or supporting academic institutions to educate people on ecological issues through research. They also were satisfied to know that the biodiversity is being protected to the benefit of current and future generations. This indicates ethical values where the local people feel they have a responsibility of stewardship for future generations. The protection, they argued would also project the history of the communities and the cultural importance of the resources to the local communities when marketed properly both at the national and international arena. That notwithstanding, the general consensus from the discussions was that local residents want immediate attention on providing alternative means to sustain their livelihoods.

Table 5.4 Importance of the Conservation Area to Local People

\begin{tabular}{lrr}
\hline & $\boldsymbol{N}$ & $\%$ \\
\hline Do you believe that KCA is an area of special importance? \\
Yes & 138 & 97.9 \\
No & 2 & 1.4 \\
No response & 1 & 0.7 \\
\hline Total & 141 & 100.0 \\
\hline If yes, which is the issue or value you ascribe to the area? \\
\hline Flora and fauna & 98 & 21.3 \\
\hline Tourism development & 15 & 3.2 \\
\hline Aesthetic/existence value & 92 & 20.0 \\
\hline Source of NTFPs/material value & 138 & 29.9 \\
\hline Ecological value & 108 & 23.4 \\
\hline Scientific/educational value & 10 & 2.2 \\
Total & 461 & 100.0 \\
\hline
\end{tabular}

Source: Community survey data (2009); ${ }^{\mathrm{a}} \mathrm{N}$ : respondents might give more than one answer.

\subsubsection{Perceptions of Local People Concerning Kakum Conservation Area Management}

The attitudes of local people were evaluated to get a general impression of their reactions towards the Kakum Conservation Area. Over all, the discussions and results from the household survey suggested that the local people would wholly support conservation of the forest and associated resources if their needs were better respected and addressed. The residents indicated the establishment of the park had not influenced the culture of the local population largely because most of these people were migrants from different indigenous communities who settled in their present locations exclusively to pursue farming. 
With regards to resource allocation, over half (53.2\%) of the respondents indicated that it has not been equitable among the communities. Further, $89.4 \%$ of the respondents were of the view that community interests were not important to management officials and therefore there were no conscious efforts to improve the living conditions or provide viable alternatives for the benefit of the local residents. Accordingly, they are hardly involved in any sort of conservation planning and management. As indicated in the survey, only $12 \%$ of the respondents had ever been involved in a conservation management related meeting $\left(\chi^{2}=5.714, p=0.017\right)$. These meetings, they noted, had been offered during the inception of the project but thereafter such activity never occurred again. The local communities are not by any special arrangements involved in managing the conservation area. Hence, there are no functional management committees or groups in the communities to oversee conservation initiatives. The local group discussants were emphatic that being left without any 'recognised' role to play in the management of the conservation area renders them powerless to check for any misuse or trespass if they do occur.

There is clear expression of alienation, mostly among respondents of community clusters one and three, due to none payment of compensations or royalties. This attitude is enforced by official none involvement of resident in conservation activities. This is further exacerbated by the perceived losses due to wildlife-crop damages and the apparent disappearance of some livelihood activities for the youth. The positive attitude of some residents and their support for conservation is dwindling fast. During a group discussion, suggestions which were supported by some community elders showed that the youth would cease on any opportunity to extract resources from the protected area, if the needs of the communities are not addressed soon. This is an indication that management authorities are neither effectively promoting nature conservation nor providing viable alternatives to make up for restricting consumptive use of the resources in the protected area. From the household survey, only $31(22 \%)$ of the respondents recalled ever having had conservation education and awareness raising in their community.

\subsubsection{Local Peoples' Involvement in Protected Area Management}

The study was particularly interested in finding out how the local people were involved in "decisionmaking concerning conservation and management of KCA" and how they could possibly be involved in "patrolling and controlling illegal activities in the area" as the main means of ensuring protection so far. In the survey of household heads and representatives, and the discussions with the community heads, it turned out that none of these local people encountered had ever been involved in any form of planning or management and the impression gathered from the group discussions was 
that the local people felt neglected by the Wildlife Officials for this reason. According to the officials however, they do depend on local residents as important informants who report any suspicious or illegal activities within the conservation area. But this is purely voluntary. The group discussions also indicated that there is lack of recognition concerning the role that local people could play in support of conservation of the protected area. Since they have the impression of not being officially recognised, they may decide to report an incident to the Wildlife officials or let it go. Nevertheless, the survey also clarified that $89 \%$ of respondents would like to participate in the management and protection of the conservation area. Given only the small number of the respondents (9\%) who indicated that they were not interested in taking part in the management of the protected area, most seems to value the conservation area (Table 5.5). Showing no interest in participation could also be a sign of mistrust as a result of not been adequately involved in the process and the unfulfilled promises made to the communities by the government and management authorities.

Table 5.5 Willingness for Awareness and Participation in Management

\begin{tabular}{|c|c|c|}
\hline Response options & Responses & $\%$ of responses \\
\hline \multicolumn{3}{|c|}{$\begin{array}{l}\text { Would you like to have more frequent conservation education } \\
\text { and awareness creation about the area and its protection? }\end{array}$} \\
\hline Yes & 107 & 75.9 \\
\hline No & 30 & 21.3 \\
\hline Indifferent & 4 & 2.8 \\
\hline \multicolumn{3}{|c|}{$\begin{array}{l}\text { Would you like to participate in the management and protection } \\
\text { of the conservation area? }\end{array}$} \\
\hline Yes & 125 & 88.7 \\
\hline No & 13 & 9.2 \\
\hline Indifferent & 3 & 2.1 \\
\hline \multicolumn{3}{|c|}{ The park officials/guards are unfriendly and interfering. } \\
\hline Agree & 48 & 34.0 \\
\hline Disagree & 54 & 38.3 \\
\hline Indifferent & 39 & 27.7 \\
\hline
\end{tabular}

Source: Community survey data (2009); Sample size, $\mathrm{N}=141$

The interview and discussions also revealed a communication gap between the communities and the Wildlife Officials. Nonetheless, the result of the survey also indicated that the Wildlife Officials engaged in some amount of "conservation education and awareness raising". With the exception of Afeaso, Mesomagor and Obengkrom, the majority of respondents indicated that conservation education at the community level was not adequate (Figure 5.3). Deductions from the group discussions and interviews with the leaders of the various communities confirmed that such activity 
is rather occasional. The study could not figure out at what frequency the community education or outreach programmes were undertaken. However, the survey result indicated that $76 \%$ of respondents would appreciate more conservation education and awareness creation concerning the park and the importance of its protection (Table 5.5).

The plight of the local people, expressed mainly by the chiefs and elders of the various village communities, is the high-handed way in which the Wildlife Officials have been dealing with community members despite their hopes and expectations and the promises made by the government at the inception of the conservation project. Correspondingly, $34 \%$ of the respondents did not consider the officials / guards to be friendly. But about $28 \%$ of the respondents did not express their opinion on the issue, leaving about $38 \%$ of respondents who were of the opinion that the officers were accommodating, friendly and are not unduly interfering in the affairs of the local communities (Table 5.5). However, as explained earlier, not openly expressing opinion about an issue could indicate a negative opinion about the subject matter. Therefore it could be assumed that about $62 \%$ of the respondents were not pleased with the officials, concerning how they treat community members in relation to protecting the area.

Figure 5.3 Conservation Education in KCA Communities

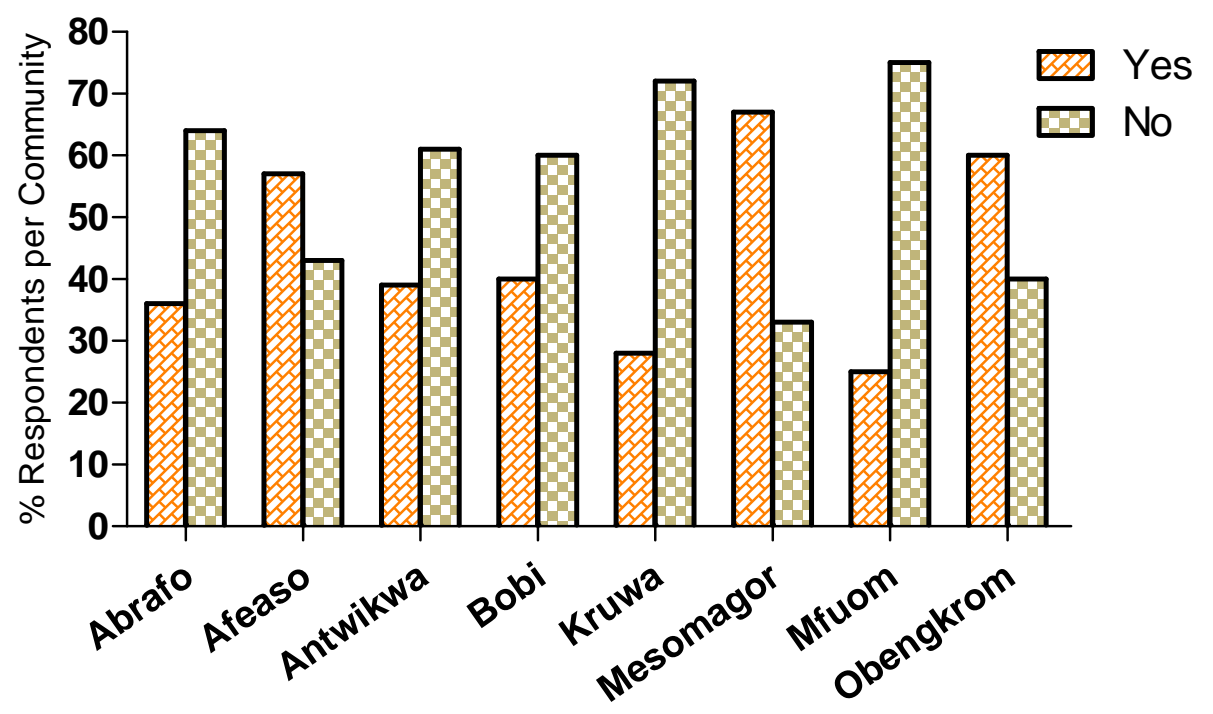

Source: Community survey data (2009)

Instead of pursuing cooperation with the local communities, conservation of the area is enforced through armed patrol guards of the Wildlife Division. There is a lack of effective community outreach programme to stress the importance of cooperation, to identify the lack or limitation of needed 
resources and to facilitate alternative access or substitution in the local communities. Accordingly all the communities indicated that they no longer enter the protected area but there are evidential records of illegal or poaching activities collected by the patrol team. Drawing on the example of Kakum, this confirms again that without adequate recognition and effective involvement of local residents in any conservation initiative, the long term success cannot be guaranteed without heavy investment in enforcing a "fence and fine system" i.e. through armed patrol guards.

Insight from the officials and local people points out that long before the reservation was instituted, the local people were protecting the forest and wildlife resources through local belief systems. For example, it was deemed a taboo to kill certain animal species. When a hunter killed an elephant or bongo, they would have to undergo rituals for cleansing and therefore to avoid such rituals, those animals were not frequently hunted. Some animals are totems and therefore members of the community have an obligation to protect them. Furthermore, they had instituted traditional resting days, where residents of every community were to stay away from the forest or their farms. These were traditionally relevant management systems to regulate the use of forest and wildlife resources. But the mode of acquisition of the forest resources by government and the subsequent disregard of the traditional authority make the local people refer to the protected area as government property. In this sense, it means the area does not belong to any one and could be exploited at will. Discussions held in the communities suggested that with the loss of access or use rights to the resources, though not a popular opinion, some community members consider the protected area as lost resource that is not worth caring for in the long term. Hence, they are not willing to protect it as before.

The chiefs and elders expressed a common opinion that the youth of the various communities would be better placed to protect the forest resources but the experience and knowledge of these local people are not considered or incorporated in the management operations. A chief's remark: "Tensions have ensued between some of the youth and the Wildlife Officers because they have together with the government denied us of our resources and yet do not recognise or see to our needs... If you imagine that we no longer have control over the forest because the government came to deceive us with promises, then you cannot help but sometimes ignore to take action against those who might unlawfully enter the forest. But if we are given responsibility for the forest, we are ready to act in the interest of conservation... If we had full responsibility for the management of the forest, we could give you assurance of protecting it. But as long as control is left in the hands of the government, we can do nothing". This opinion is echoing the feelings and views of the majority of traditional authorities in the individual village communities and possibly at the paramountcy levels. 
The study correspondingly observed that by not involving local people, local knowledge and skills are grossly being ignored. As a result, local systems of decision making and resource management have been eroded as they have been replaced by professional bodies with their associated bureaucracy.

\subsection{Opportunities and Challenges in Management}

In the current dispensation of natural resource management it is recognised that local organisations are crucial in the general conservation and sustainable use of forest and wildlife resources. Cernea (1993) stated that "resource degradation in developing countries, while incorrectly attributed to 'common property systems' intrinsically, actually originates in the dissolution of local level institutional arrangements whose very purpose was to give rise to resource use patterns that were sustainable". Local or traditional institutions have been known to enforce rules, give incentives to those who observe the rules and meet out penalties to people for contravening agreed regulations. Traditional institutions created conducive frameworks that facilitated rational and effective use of natural resources and its conservation. In Kakum however, although the area under protection traditionally falls under the jurisdiction of four paramount chiefs who originally owned the area, these paramount chiefs and their representative chiefs at the various community levels are not actively involved in its management due to the top-down management approach. This leaves the few wildlife guards with the daunting task of managing and defending the protected area. Thus, the current state of conservation management renders traditional local institutions, and the people they represent, powerless over conservation management, but at the same time, the formal institutions have not proved to be a successful replacement without militant protective measures. Thus, the alienation and none-involvement of chiefs and local people in decision-making concerning management of the area have resulted in some of the difficulty faced with local communities.

Admittedly, management officials of KCA conceded that adequate involvement of traditional authorities or local chiefs would have facilitated effective management of the conservation area. OtiAwere ${ }^{9}$ (2009, per com.) noted that "without community involvement, conservation in Ghana will not work. In our context, the communities are the most important stakeholders of the forest and wildlife resources and they can put up the biggest defence" that is to safeguard the resources, particularly where the chiefs and elders of the rural communities are adequately involved. Indeed the organisational structure of the traditional heads or chiefs make them accountable to their paramountcy and therefore when these authority structures are adequately involved, local chiefs could lead the campaign for natural resource conservation at the community level.

\footnotetext{
${ }^{9}$ Oti-Awere is the Head of Marketing and Promotion Unit at the Wildlife Division Headquarters in Accra
} 
In every local community, the people are organised under the chief and council of elders. The chiefs are deemed as the mouth piece of communities and the subjects or residents respect their authority because they act for their ancestors as custodians of the community. Thus the position of the chief is highly recognised. Also by the local traditions and settings, mutual obligations join the members of the community to the chief and therefore are obliged to respect laid down rules within the community in recognition of the chief's authority and the overall wellbeing of the community. Beyond intra-community networks, there are inter-community networks through family relations and friends (Figure 5.4). This can be a potential resource for networking conservation initiatives among communities around the conservation area. More importantly, the structure and organisation of traditional authority/leadership within communities makes it an important and dependable organisation through which conservation of forest and wildlife resources could have been pursued.

Figure 5.4 Family Relations or Friends in Other Communities within KCA

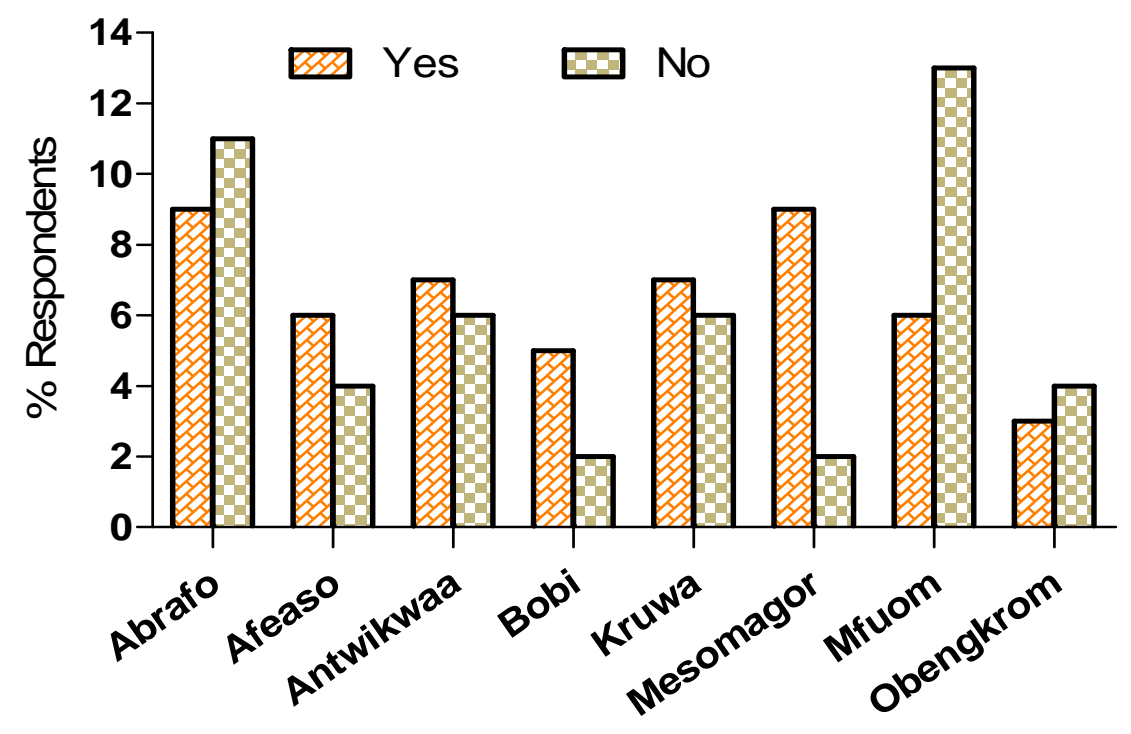

Source: Community survey data (2009)

Additionally, other socio-political organisations like the area and unit committees, fire volunteer squads and women's movements also operate in the local communities as a rallying point for communal activity and community development. These organisations could be re-enforced to form a network of intelligence to effectively monitor both resident and none-residents with respect to forest and wildlife management and conservation at the community level.

On the other hand, according to Galvin and Haller (2008), implementing systems of managing protected areas that include local communities concerns or their active participation could help in 
eliminating various problems, such as poaching. An argument can therefore be made in favour of integrating local people's interest in the management, in order to win their full support and involve them in the ultimate protection of the forest and wildlife resources. The active involvement of local people and their traditional authorities definitely could constitute a far more effective management regime. Paavola (2004) and Dearden, et. al. (2005) have observed an increasing trend towards greater participation by stakeholders and the use of formal accountability mechanisms to guarantee the legitimacy and effectiveness of grassroots organizations.

Even though the study calls for integrating community interest in protected area management in order to ensure their support for conservation, it is also important to note that the word community lacks precise meaning. It has been explained variously as a group of people living together in one place, or having a religion, or other particular characteristic in common, among others. But to bring our purpose to focus, the study agrees with Pearce, et. al. (1996) who suggests that an emphasis on "local" derives its legitimacy from an implicit assumption of the cohesion of "local communities". Community, they contend, embraces notions of spatial contiguity, social interaction, and notions of shared aspirations and value. According to Dei (1993), the ideology of community stresses the value of cooperation, reciprocity and interdependence. Hence, with issues concerning their livelihood and survival, they are more likely to act for the common good of the local community. Particularly where they rely on the environment to a large extent to secure their livelihoods, they are the primary beneficiaries and therefore would commit to ensure safeguarding the environment around them which would consequently translate into nature conservation if they are well involved in the processes.

Other issue to take into consideration however, is that true participation or local people's involvement cannot be achieved if the range of local participants is not an adequate representation of the entire population. This is even more challenging where there are many local communities within the conservation area because it can inflate the number of people that should be involved in the management of the protected area thus rendering operations ineffective. In the real life situation, every management action would have to be taken on consensus but it is envisaged that representations from different communities might pursue different agenda and compound consensus building. To avert this through professional and effective mediation mechanisms might be a challenge.

Effective management of protected areas, however, is not only about involvement of stakeholders, in this case, the traditional authorities and the resident local people. It is also about the execution of power and about who has how much influence, who makes the decisions, and how the decision- 
makers are held accountable (Graham, et. al., 2003). In the traditional institutional setting, chiefs at all levels perform executive, legislative and judicial functions. But more important, all divisional and village chiefs are accountable to the paramount chiefs. This gives a clear structure of authority and accountability. Based on traditional and cultural beliefs, the position of a chief is highly recognised. Hence, the involvement of local traditional authorities has a great potential to rally local residents in favour of conservation and to assist in protecting the area against outside poachers. According to some local elders, access to and uses of natural resources were once regulated through elaborate social rules which were embedded in spiritual beliefs. The belief systems were employed for the protection of nature and the subsistence use of natural resources which were considered as an embodiment of their existence. These mechanisms were used to ensure the sustenance of their livelihoods and protection of their ancestral land and heritage. Therefore, for the local communities, concern about their involvement is not only motivated by the desire to conserve 'biodiversity' as an end in itself, but also by the need to safeguard local food security, live on own land and, exercise local economic, cultural and traditional autonomy and to appease their ancestors.

However, a complex of new challenges also confronts protected areas and natural resource management. There is a move towards a more materialistic culture even in remote or rural communities. This is bolstered by trends such as globalisation, market liberalisation, population growth, migration and urbanisation. People are more concerned about the accumulation of private property or wealth and therefore pay very little attention to the maintenance of the public good aspect of biodiversity. Furthermore, the traditional and religious beliefs which helped to conserve biodiversity in the past are no longer as effective due to western education and immigration of people from other ethnic groups who may not believe in the traditions of a particular area. And finally, local people's attitude towards biodiversity also changes continually as their perception of what they need or want is influenced by exposure and interaction with the world outside their communities, by technological progress and by their perception of their affluence or livelihood standards in relation to others.

The communities around the conservation area are poor and they still depend on natural resources, as noted earlier, to supplement their subsistence livelihood which is mainly based on farming. Many of the local communities still rely on traditional medicines harvested directly from the wild for maintaining their health and well-being. During the survey, many herbal practitioners were observed, suggesting a resurgence of interest in herbal medicine as a source of remedies as there are no easy accesses to orthodox medicine or clinics for most of the communities within the KCA. Likewise, many of the local residents depend on NTFPs as building materials and source of protein. These are basic 
necessities for which, without viable alternatives, many would go to any extent to acquire which result in the illegal and poaching activities that could be observed. During the discussions with community groups and the Wildlife Officials, they admitted that although poaching activities has generally decreased after increasing the patrol man-days, it is impossible to completely prevent illegal activities in the conservation area particularly in view of current resources and staff strength. Thus the inability to address the poaching, referred to as a "silent protest" by Abane, et. al., (1999), could ultimately undermine the conservation efforts and sustainability of Kakum.

In such instance, integrating community interests by aiding and or providing alternative sources for their basic needs would serve as an incentive for effective involvement of resident local people in conservation activities. The study did not find indications of any definite defensive posture towards the conservation area even though dissatisfaction has been expressed in all the communities. Responses from the survey rather indicate some amount of willingness for recognition and participation in the management (Table 5.5). Management officials could capitalise on this willingness of the local people by giving them some definite responsibilities with commensurate benefits to increase the effectiveness of protection.

Another fact to put into consideration is that the population of the fringe communities in KCA certainly have been increasing over the years while the amount of land to work and fulfil livelihood needs remained the same or even shrank due to conservation restrictions. Logically, this exerted pressure and induced competition among residents concerning the use of available land and natural resources. As the available natural resources outside the conservation area get exploited and possibly degraded, local residents who do not see any alternatives might tend to take advantage of the conservation area for resources which increases the pressure on the wildlife guards to monitor and control illegal activities (see section 4.4.1). According to the patrol records of the wildlife guards, there were 801 and 875 recorded incidences of serious offences or poaching activities in 2007 and 2008 respectively. Anyway 42 wildlife guards distributed in seven camps to keep watch on the activities of local people in over fifty communities scattered around a $360 \mathrm{~km}^{2}$ conservation area is quite a challenge. With the support of some resident local volunteers, this challenge could be reduced particularly since there are reports that many of the illegal activities in the conservation area arise from people who live in more distant communities and not necessarily those adjacent or close to the boundaries of KCA.

Unfortunately, despite the knowledge of widespread use of NTFPs, protected area management plans generally pay very little, if any, attention to the importance of NTFPs for local livelihood security. In Ghana, according to Dei (1989), wild foods are particularly important during times of food 
shortages known as the hunger season which precedes crop harvests. Dei (1989) contends that before crop harvest in Ghana, farm households on the average obtained $16-20 \%$ of their food supply from the forest or bush as compared to $6 \%$ after the harvest. This underscores the importance of NTFPs to rural livelihood. It is incumbent therefore to secure these needs of local people in the wake of establishing and managing protected areas. The needs and priorities of local resident people could only be met when they are actively involved in the planning and management of the areas set aside for conservation. Undoubtedly, one cannot preclude that resident people local do also take part in the illegal activities observed in the protected area. But the expression of willingness from others to participate in protection and management of the area might nonetheless raise the surveillance capacity and its efficiency. It is the immediate local people who best know the area, the everyday life and the social interactions in the communities. If their interests are taken into account in the management and their cooperation would be welcome and appreciated, the temptation to poach could be averted. Would-be-poachers could become efficient protectors of wildlife and forest resources.

\subsection{Conclusions}

The establishment of PAs often necessitate residents living in or adjacent to these areas to adjust their livelihoods and lifestyle, as natural resources (NTFPs) they were formerly using became inaccessible. They either had to find a substitute, obtain them from somewhere else or ignore the restriction, better to say exclusions from use that had been imposed on them. Until today, this presents a lot of challenge and annoyance to management officials as they are only able to maintain the regulations of strict protection through the implementation of a 'fence and fine system' enforced by armed guards.

In recognition of the relevance of local people's influence, use of resources and the role they could play in ensuring the success of biodiversity conservation programmes, the principal conservation paradigm has moved towards more community or local people's involvement today. The study looked at local people's perception of present management performance, their attitude towards the protected area and their interest in being involved in the management of KCA. The main results and conclusions of the study are the following:

The Kakum Conservation Area still follows an administrative top-down management approach enforced by wildlife patrol guards. But there has not been any adequate provision of alternative resources to make up for the loss of access to NTFPs such as construction materials. The collection of 
NTFPs used to be an essential part of their livelihood activities. Since the establishment of KCA, collection of NTFPs is considered illegal. Nevertheless, the wildlife patrol guards continuously encounter illegal activities and sometimes arrest poachers. Thus poaching and illegal activities remain a constant challenge to the management authorities.

The local people are not involved in the conservation of KCA. They feel neglected and disregarded by the management officials because they are excluded from any decision-making or management concerning the area. The officials work independently from the local communities and do not have any distinct role assigned to them. However, over $97 \%$ of the respondents deem the protected area as important for conservation with another $88.7 \%$ expressing interest to participate in the management

There is a communication gap between the communities and the Wildlife officials. This is bringing $34 \%$ of the respondents to consider the officials/guards to be unfriendly. Over $75 \%$ of respondents would appreciate more conservation related education and awareness raising concerning the park and the importance of its protection. There is also lack of programmes to stress the importance of cooperation, and to facilitate the identification and development of alternative avenues to needed resources. Further, the communities share land border with the protected area, without any buffer zone. Effective cooperation and involvement of the local people would be useful in managing the interface between the protected area and the agricultural lands.

The current state of conservation management also renders traditional knowledge, strategies and the respective local institutions powerless with respect to conservation issues. The local or traditional authorities are not involved and their systems of resource management have been eroded as they have been replaced by professional bodies with their associated bureaucracy. But management officials conceded that adequate involvement of traditional authorities or local chiefs would have facilitated effective management of the conservation area. The chiefs are custodians of the community and therefore are respected. Mutual obligations bind local residents and their representative chiefs. The residents of every community are obliged to respect laid down rules in recognition of the chief's authority. This presents an opportunity to rally local people in support of conservation when it is spearheaded by their chiefs.

The alienation and none-involvement of chiefs and local people in decision-making concerning the management of the area have resulted in some of the difficulty faced with local communities. However, local people in the communities close to protected areas are presumed to have the deepest knowledge about the environment so the incorporation of their interest and involvement 
would enable the development of a more efficient protection of natural resources within the locality and the adjoining protected areas. KCA therefore needs to develop management strategies that do actively involve the resident local people in order to support the parks maintenance. 


\subsection{References}

Abane, A., Awusabo-Asare, K., and Kissi, A. K. 1999. In whose interest? Individual and societal needs in the creation of forest reserves: the case of Kakum in Ghana. Bulletin of the Ghana Geographical Association 21: 21 - 30 Accra: University of Ghana

Barrow, E. and Murphree, M. 2001. Community conservation from concept to practice: a practical framework. In: Hulme, D. and Murphree, M. (ed.). African Wildlife and Livelihoods: The Promise and Performance of Community Conservation, pp. 24-37. Oxford, UK: James Currey. (http://www.sed.manchester.ac.uk/idpm/research/publications/archive/cc/cc_wp08.pdf)

Berkes, F. 2007. Community-Based Conservation in a Globalized World. Proceedings of theNational Academy of Sciences of the United States of America 104(39): 15188-15193

Brandon, K., Redford, K. H. and Sanderson, S. E., (eds). 1998. Parks in Peril: People, Politics, and Protected Areas. Washington, DC, USA: Island Press

Brechin, S. R., Wilshusen, P. R., Fortwangler, C. L. and West, P. C. 2002. Beyond the Square Wheel: Toward a more Comprehensive Understanding of Biodiversity Conservation as Social and Political Process. Society and Natural Resources 15: 41-64

Cernea, M. M. 1993. Culture and Organisation: The Social Sustainability of Induced Development. Sustainable Development 1(2): $18-29$

(http://onlinelibrary.wiley.com/doi/10.1002/sd.3460010207/pdf) (12.10.2010)

Chapin, M. 2004. A Challenge to Conservationists. World Watch Magazine 17(6):17-31

da Silva, P. P. 2004. From Common Property to Co-management: Lessons from Brazil's First Maritime Extractive Reserve. Marine Policy 28: 419-428

Dearden, P., Bennett, M., and Johnston J. 2005. Trends in Global Protected Area Governance, 19922002. Environmental Management 36:89-100

Dei, G. J. S. 1989. Hunting and Gathering in a Ghanaian Rain Forest Community. Ecology of Food and Nutrition, 22: 225-243

Dei, G. J. S. 1993. Indigenous African Knowledge Systems: Local Traditions of Sustainable Forestry. Singapore Journal of Tropical Geography 14(1):28-41

Earth Trends. 2003. Biodiversity and Protected Areas - Ghana. Country Profiles. (http://earthtrends.wri.org/pdf library/country profiles/bio cou 288.pdf) (12.10.2010)

Galvin, M and Haller, T. (eds). 2008. People, Protected Areas and Global Change: Participatory Conservation in Latin America, Africa, Asia and Europe. Perspectives of the Swiss National Centre of Competence in Research (NCCR) North-South, University of Bern, Vol. 3. Bern: Geogra-Bernensia, $560 \mathrm{pp}$

Gomez-Pompa A. and Kaus, A. 1992. Taming the Wilderness Myth. Bioscience 42(4): 271-279

Graham, J., Amos, B. and Plumptre, T. 2003. Governance Principles for Protected Areas in the 21st Century. Discussion Paper. Ottawa, Ontario, Canada: Institute on Governance in collaboration with Parks Canada and the Canadian International Development Agency. 
(http://iog.ca/sites/iog/files/pa_governance2.pdf) (10.01.2011)

Haller, T., Galvin, M.,Meroka, P., Alca, J. and Alvarez, A. 2008. Who Gains from Community Conservation? Intended and unintended costs and benefits of participative approaches in Peru andTanzania. The Journal of Environment and Development 17: 118- 144

Horwich, R. H. and Lyon, J. 2007. Community conservation: practitioners' answer to critics. Oryx 41: 376-385

Hough, J. L. 1988. Obstacles to Effective Management of Conflicts between National Parks and Surrounding Human Communities in Developing Countries. Environmental Conservation 15(2): 129136

Ite, U. E. 1996. Community perceptions of the Cross River National Park, Nigeria. Environmental Conservation 23(4): 351-357

Manning, R. E. 1989. The Nature of America: Visions and Revisions of Wilderness. Natural Resources Journal, 29: 25-40. (http://heinonline.org/HOL/Page?handle=hein.journals/narj29\&div= $10 \& g$ sent $=1 \&$ collection=journals) $(12.01 .2011)$

Nepal, S. K. 2002. Involving Indigenous Peoples in Protected Area Management: Comparative Perspectives from Nepal, Thailand, and China. Environmental Management 30(6):748-763. doi:10.1007/s00267-002-2710-y

Paavola J. 2004. Protected Areas Governance and Justice: Theory and the European Union's Habitats Directive. Environmental Sciences 1:59-77

Pavlikakis, G.E., Tsihrintzis V.A. 2006. Perceptions and preferences of the local population in Eastern Macedonia and Thrace National Park in Greece. Landscape and Urban Planning 77: 1-16

Pearce, P., Moscardo, G., and Ross, G. 1996. Tourism Community Relationships. Oxford: Pergamon

Peters, J. 1999. Understanding Conflicts between People and Parks at Ranomafana, Madagascar. Agriculture and Human Values 16: 65-74

Skonhoft, A. 1998. Resource Utilization, Property Rights and Welfare - Wildlife and the Local People. Ecological Economics 26:67-80

Smith, R. J., Muir, R. D. J., Walpole, M. J., Balmford, A., and Leader-Williams, N. 2003. Governance and the Loss of Biodiversity. Nature 426: $67-70$

Spiteri, A. and Nepal, S. K. 2006. Incentive-Based Conservation Programs in Developing Countries: A Review of Some Key Issues and Suggestions for Improvements. Environmental Management $\quad 37$ : $1-14$

Tello, B., Fiallo, E. A. and Naughton-Treves, L. 1998. Ecuador: Podocarpus National Park. In: Brandon, K., Redford, K.H. and Sanderson, S.E. (eds.) Parks in Peril: People, Politics, and Protected Areas pp. 287-322. Washington, DC, USA: Island Press

Thakadu, O.T. 2005. Success Factors in Community Based Natural Resources Management in Northern Botswana: lessons from practice. Natural Resources Forum 29: $199-212$ 
Toledo, V. M. 2001. Indigenous peoples and biodiversity. In: Levin, S. A. (ed.) Encyclopedia of Biodiversity, Academic Press, 20 pp

West, P., Igoe, J., and Brockington, D. 2006. Parks and People: The Social Impact of Protected Areas. Annu. Rev. Anthropol. 35:251-77 (http://www.cerium.ca/IMG/pdf/Parks_and_people.pdf) (10.01.2011) 


\section{Chapter Six: Visitor Characteristics, Expectations and Satisfaction with Recreation in the Kakum Conservation Area}

\subsection{Introduction}

The rapid development and widening appeal of ecotourism has raised significant challenges for the ecotourism sector (Wight 1993; Reynolds and Braithwaite, 2001). That is, due to the hype and the growing interest of tourists in ecotourism, operators offering ecotourism experiences face increasing pressure to ensure that the diverse tourists who patronise their products receive the experiences that they anticipate. Hvenegaard (1994) remarked that since the term ecotourism is widely used, many tourists may not be sure of the product offered by ecotourism operators and the qualities of the experience that they seek to provide.

Though the primary goals of ecotourism focuses on environmental protection, awareness, and local economic development, the creation of positive experiences within visitors is also imperative to the longevity of the ecotourism industry. Thus, related to any tourism experience is the level of visitor satisfaction (Ellis and Vogelsong, 2002). Many tourism products are intentionally marketed as ecotourism even though they do not meet the core criteria. Ecotourism is promoted based on some assumptions. These are; first, its scale is small therefore its impact on the environment is also less; second, the type of tourists are different and more environment conscious so interactions on the destinations are less disruptive; finally, the range of opportunities for local involvement and benefits are greater. In this regard, Chirgwin and Hughes (1997) have noted that there has been considerable debate on what actually constitutes an ecotourism experience and satisfaction.

The difficulty is to determine what exactly constitutes satisfaction in ecotourism experience. Dorfman (1979) attempted to clarify the meaning of satisfaction in the context of recreational camping. He stated that satisfaction levels are "maximised when aspiration (desirability) equals perception but only when the desirability is high for that condition" (Dorfman, 1979). Tourists have certain preconceived notions and mental images of a location before they ever visit. Therefore, expectations are one of the driving forces for the initial desire to visit a particular location. If the visitor's high expectations are met, then high visitor satisfaction is likely. Conversely, an individual with high expectations who receives a low-value experience will likely report low satisfaction.

Reynolds and Braithwaite (2001) claimed that ecotourists' satisfaction is influenced by physical attributes including tangible and intangible factors of the tourism site including facilities, design and weather. Furthermore, the guide's interpretation and role, variety and the uniqueness of the eco- 
experiences are also important factors in determining ecotourists' satisfaction. Hence, Geva and Goldman (1991) affirmed in their study that a tour guide's quality was an important variable in tourists' satisfaction. Nonetheless, Ryan (1995) has also indicated that satisfaction is a complex concept that depends on a variety of factors and therefore difficult to measure.

The level of tourists' satisfaction could determine whether one recommends or revisits a site. There have been few empirical studies about tourist satisfaction and the intention of recommending or revisiting a site. Opperman (2000) conducted a study on tourism destination loyalty and reported that travel experiences significantly influenced future destination selection by a visitor. Mazursky (1989) also showed that the intention to recommend and revisit a site was influenced by tourists' satisfaction. In this respect, some authors have argued that repeat visitation displays a certain level of individual satisfaction and attachment to a particular location and/or activity (Gitelson and Crompton, 1984; Yuksel, 2001). Consequently, the authors noted that tourist attractions have been found to rely heavily on loyal and repeat visitors. It is therefore safe to assume that satisfied tourists are likely to revisit sites and produced more tourists. Accordingly, several authors (Whipple and Thach, 1988; Mazursky, 1989; Baker and Crompton, 2000) have shown that the higher satisfaction tourists had, the more they intended to revisit a site and promote it by word-of-mouth. Similarly, Pearce (1988) also claimed that tourists who were satisfied recommended the sites and revisited them. However, unsatisfied tourists did not recommend sites, nor revisit them, and consequently spread negative word-of-mouth about them. The ecotourists' satisfaction significantly influenced the intention of recommendation as shown in previous studies (Whipple and Thach, 1988; Mazursky, 1989; Baker and Crompton, 2000).

Visitors to ecotourism attractions may be generally classified as ecotourists whilst on-site yet they represent a broad range of demographic characteristics, personal backgrounds, travel preferences, motivations and interests (Wight 1996; Boyd and Butler, 1996; Burton, 1998). Hence they would have different expectations. The diversity of visitor types that are represented within ecotourism activities and the possible impacts associated with their behaviour would also need to be considered in the further development of ecotourism in any destination. Considering that the ecotourists represent a wide range of interests, there are advantages to be achieved for both the ecotourism service providers in characterising the visitors to ecotourism sites. Hence, profiling visitors to ecotourism destinations and the experiences that they report is critical to the further development of the destination and the ecotourism sector at large. Though research results on satisfaction could be simplistic due to the complexity of what constitutes satisfaction, it still could uncover issues raised by 
visitors to improve on the ecotourism experience. For this study, information concerning visitor demographics, expectation for additional recreation options and satisfaction were collected during a visitor survey in the Kakum Conservation Area. The purpose was to characterise visitors to Kakum and explore their level of satisfaction with their tourism experience in Kakum. The study also assessed the visitors' intentions for future repeat visits and interest in the development of additional options for recreation in Kakum.

\subsection{Methodology: Data Collection and Analysis}

Data collection for the study was conducted at the visitor centre at Kakum. This was because every visitor comes to the centre before and after any recreational experience in the park. The visitors who took part in the survey represent different socio-economic, educational, occupational groups and nationalities. The selection of respondents was random. However, to qualify for the survey as a respondent, the visitor should have participated in a tour or activity within the park. Respondents filled out questionnaires (Appendix 2) aimed at collecting demographic information, impressions on the park, options for recreation, and expectations for further improvements to enhance the experience of visitors. The data for visitation trends and activities was extracted from the existing visitor registration records of the Wildlife Division office at the Kakum Conservation Area. Originally the analysis was intended to base on the nationality of respondents. However, since most of the respondents did not indicate their nationality but the country of residence, all the analysis was subsequently based on the country of residence which was recoded as origin and presented in two groups (respondents' residents in Ghanaians and respondents' resident in foreign countries). Descriptive statistics were derived to summarise demographic information on the respondents while inferential statistical analysis were used to assess the relationships between the demographic parameters and all other interested variables related to satisfaction. The analyses were conducted using the Statistical Package for Social Sciences (SPSS) ver. 16 (at 95\% significant level).

\subsection{Results}

\subsubsection{Demographic Characteristics of Respondents}

A total of 423 respondents took part in the survey representing 30 countries including those residents in Ghana. The largest single source of respondents was those resident in Ghana 189 (44.7\%). The sources of international visitors were dominated by the United States of America 50 (11.8\%) and United Kingdom 40 (9.5\%). Other important sources of visitors include Germany, Netherlands and Canada. When the sources of the international resident visitors was aggregated, the 
Europe resident respondents emerged as the most significant group $128(30.2 \%)$, followed by the Americas 64 (15.1\%) and other African countries 28 (6.6\%), with Asia 14 (3.3\%) being the least represented. This is supported by the observations made during the survey where visitors of Asian origin were infrequently observed at the visitor centre.

Table 6.1 Chi-square test of the relationship between demographic variables and desire for more recreational opportunities by respondents resident in Ghana

\begin{tabular}{|c|c|c|c|c|c|c|c|}
\hline \multirow[t]{2}{*}{ Parameter } & \multirow[t]{2}{*}{ Variable } & \multirow{2}{*}{$\begin{array}{l}\text { Frequency } \\
\text { (\%) of } \\
\text { respondents }\end{array}$} & \multirow{2}{*}{$\begin{array}{l}\text { Number } \\
\text { included } \\
\text { in test }(n)\end{array}$} & \multicolumn{2}{|c|}{$\begin{array}{l}\text { More } \\
\text { recreation (n) }\end{array}$} & \multirow[t]{2}{*}{$X^{2}$} & \multirow[t]{2}{*}{$P$} \\
\hline & & & & Yes & No & & \\
\hline \multirow[t]{2}{*}{ Gender } & Male & 75 (39.7\%) & \multirow[t]{2}{*}{186} & 67 & 7 & \multirow[t]{2}{*}{.214} & \multirow[t]{2}{*}{.644} \\
\hline & Female & $114(60.3 \%)$ & & 99 & 13 & & \\
\hline \multirow[t]{4}{*}{ Age } & $<20$ & $120(63.5 \%)$ & \multirow[t]{4}{*}{186} & 113 & 7 & \multirow[t]{4}{*}{22.108} & \multirow[t]{4}{*}{.000} \\
\hline & $20-37$ & $51(27.0 \%)$ & & 41 & 8 & & \\
\hline & $38-54$ & $14(7.4 \%)$ & & 11 & 2 & & \\
\hline & $>54$ & $4(2.1 \%)$ & & 1 & 3 & & \\
\hline \multirow[t]{3}{*}{ Education } & $\begin{array}{l}\text { Secondary/ } \\
\text { High School }\end{array}$ & $126(66.7 \%)$ & \multirow[t]{3}{*}{186} & 117 & 9 & \multirow[t]{3}{*}{7.070} & \multirow[t]{3}{*}{.029} \\
\hline & $\begin{array}{l}\text { College/ } \\
\text { Polytechnic }\end{array}$ & $20(10.6 \%)$ & & 17 & 2 & & \\
\hline & $\begin{array}{l}\text { University } \\
\text { Degree }\end{array}$ & $43(22.8 \%)$ & & 32 & 9 & & \\
\hline \multirow{5}{*}{$\begin{array}{l}\text { Occupation/ } \\
\text { Employment }\end{array}$} & Student & $130(73.0 \%)$ & \multirow[t]{5}{*}{175} & 119 & 11 & \multirow[t]{5}{*}{17.091} & \multirow[t]{5}{*}{.002} \\
\hline & $\begin{array}{l}\text { Education/ } \\
\text { Scientist }\end{array}$ & $17(9.6 \%)$ & & 14 & 3 & & \\
\hline & $\begin{array}{l}\text { Technical / } \\
\text { Services }\end{array}$ & 20 (11.2\%) & & 17 & 1 & & \\
\hline & Health & $5(2.8 \%)$ & & 2 & 2 & & \\
\hline & Other & 6 (3.4\%) & & 3 & 3 & & \\
\hline \multirow[t]{2}{*}{ In a group } & Yes & $176(94.1 \%)$ & \multirow[t]{2}{*}{185} & 157 & 18 & \multirow[t]{2}{*}{.926} & \multirow[t]{2}{*}{.336} \\
\hline & No & $11(5.9 \%)$ & & 8 & 2 & & \\
\hline \multirow{2}{*}{$\begin{array}{l}\text { Family } \\
\text { Group }\end{array}$} & Yes & $24(13.0 \%)$ & \multirow[t]{2}{*}{183} & 16 & 8 & \multirow[t]{2}{*}{15.637} & \multirow[t]{2}{*}{.000} \\
\hline & No & $160(87.0 \%)$ & & 148 & 11 & & \\
\hline
\end{tabular}

As presented in Tables 6.1 and 6.2, the majority of respondents were females. Overall, there were 249 (58.9\%) females as compared to $174(41.1 \%)$ male respondents across a wide age range who were more willing to fill the survey questionnaires. Age is thought to be a relevant factor when visitors decide what specific recreational activity to engage in, particularly in tropical forest areas. Therefore the respondents were sorted into four age groups. Among the respondents resident in Ghana, the majority 120 (63.5\%) were under 20 years, followed by those between 20-37 years and between $38-54$ years, constituting $51(27.0 \%)$ and $14(7.4 \%)$ respectively. Finally the least respondents $4(2.1 \%)$ were those over 54 years old (Table 6.1$)$. On the other hand, the majority $142(60.7 \%)$ of the foreign resident respondents were in the 20-37 age group, followed by 38-54 year group, with the under 20 years being the least represented (Table 6.2). Altogether, this indicates that visitors to Kakum are mostly young and possess the energy and rigour to undertake the adventure and thrill 
that Kakum offers. Details of respondents' educational levels, occupation, whether in a group or family are also presented in Tables 6.1 and 6.2. The majority of respondents, both the resident and non-resident in Ghana, came in a group of which only 24(13.0\%) (Table 6.1) and 36(17.1\%) (Table 6.2) were family groups respectively. The employment status of the respondents also confirms a preponderance of students (73\%) among those resident in Ghana (Table 6.1) compared to the foreign resident respondents who were dominated by employees, constituting about $74 \%$ (Table 6.2) visiting Kakum. Furthermore, visitors to Kakum can be said to generally have high educational achievement. However, it should be noted that over $85 \%$ of the foreign resident respondents had tertiary education as opposed to about only a third of those resident in Ghana.

Table 6.2 Chi-square test of the relationship between demographic variables and desire for more recreational opportunities by respondents resident in foreign countries

\begin{tabular}{|c|c|c|c|c|c|c|c|}
\hline \multirow[t]{2}{*}{ Parameter } & \multirow[t]{2}{*}{ Variable } & \multirow{2}{*}{$\begin{array}{l}\text { Frequency } \\
\text { (\%) of } \\
\text { respondents }\end{array}$} & \multirow{2}{*}{$\begin{array}{l}\text { Number } \\
\text { included } \\
\text { in test }(\mathrm{n})\end{array}$} & \multicolumn{2}{|c|}{$\begin{array}{l}\text { More } \\
\text { recreation (n) }\end{array}$} & \multirow[t]{2}{*}{$X^{2}$} & \multirow[t]{2}{*}{$P$} \\
\hline & & & & Yes & No & & \\
\hline \multirow[t]{2}{*}{ Gender } & Male & 99 (42.3\%) & \multirow[t]{2}{*}{212} & 53 & 35 & \multirow[t]{2}{*}{.006} & \multirow[t]{2}{*}{.936} \\
\hline & Female & 135 (57.7\%) & & 74 & 50 & & \\
\hline \multirow[t]{4}{*}{ Age } & $<20$ & $16(6.8 \%)$ & \multirow[t]{4}{*}{212} & 12 & 3 & \multirow[t]{4}{*}{8.332} & \multirow[t]{4}{*}{.040} \\
\hline & $20-37$ & $142(60.7 \%)$ & & 80 & 45 & & \\
\hline & $38-54$ & 47 (20.1\%) & & 24 & 21 & & \\
\hline & $>54$ & $29(12.4 \%)$ & & 11 & 16 & & \\
\hline \multirow[t]{3}{*}{ Education } & $\begin{array}{l}\text { Secondary/ } \\
\text { High School }\end{array}$ & 34 (14.5\%) & \multirow[t]{3}{*}{212} & 21 & 7 & \multirow[t]{3}{*}{3.147} & \multirow[t]{3}{*}{.207} \\
\hline & $\begin{array}{l}\text { College/ } \\
\text { Polytechnic }\end{array}$ & 63 (26.9\%) & & 32 & 22 & & \\
\hline & $\begin{array}{l}\text { University } \\
\text { Degree }\end{array}$ & $137(58.5 \%)$ & & 74 & 56 & & \\
\hline \multirow{5}{*}{$\begin{array}{l}\text { Occupation/ } \\
\text { Employment }\end{array}$} & Student & $61(26.1 \%)$ & \multirow[t]{5}{*}{212} & 33 & 20 & \multirow[t]{5}{*}{3.277} & \multirow[t]{5}{*}{.513} \\
\hline & $\begin{array}{l}\text { Education/ } \\
\text { Scientist }\end{array}$ & $23(9.8 \%)$ & & 10 & 10 & & \\
\hline & $\begin{array}{l}\text { Technical / } \\
\text { Services }\end{array}$ & 69 (29.5\%) & & 42 & 21 & & \\
\hline & Health & $30(12.8 \%)$ & & 13 & 13 & & \\
\hline & Other & $51(21.8 \%)$ & & 29 & 21 & & \\
\hline \multirow[t]{2}{*}{ In a group } & Yes & $173(75.2 \%)$ & \multirow[t]{2}{*}{211} & 89 & 70 & \multirow[t]{2}{*}{3.753} & \multirow[t]{2}{*}{.053} \\
\hline & No & $57(24.8 \%)$ & & 37 & 15 & & \\
\hline \multirow{2}{*}{$\begin{array}{l}\text { Family } \\
\text { Group }\end{array}$} & Yes & $36(17.1 \%)$ & \multirow[t]{2}{*}{197} & 11 & 18 & \multirow[t]{2}{*}{6.166} & \multirow[t]{2}{*}{.013} \\
\hline & No & $175(82.9 \%)$ & & 105 & 63 & & \\
\hline
\end{tabular}

\subsubsection{Motivation, Activities and Trends of Visitation}

Since opening up the park to visitors and the inception of tourism activities in 1992, there has been a steady increase in visitor numbers to Kakum. Tourists have shown interest in the recreational activities on site. Figure 6.1 gives a representation of only seven years of total visitation trends in Kakum but reflects the mentioned increase in visitation. The total visitation has more than doubled from over 42,500 in 2002 to over 96,500 in 2008. However, it should be noted that while there is an 
overall increase in visitor numbers, the proportion of foreign resident visitors remained low and relatively constant, constituting about only $24 \%$ of the overall visitors, although the foreign resident visitor numbers has also more than doubled from about 11,000 in 2002 to about 24,400 in 2008.

Figure 6.1 Trends of Visitations in the Kakum Conservation Area

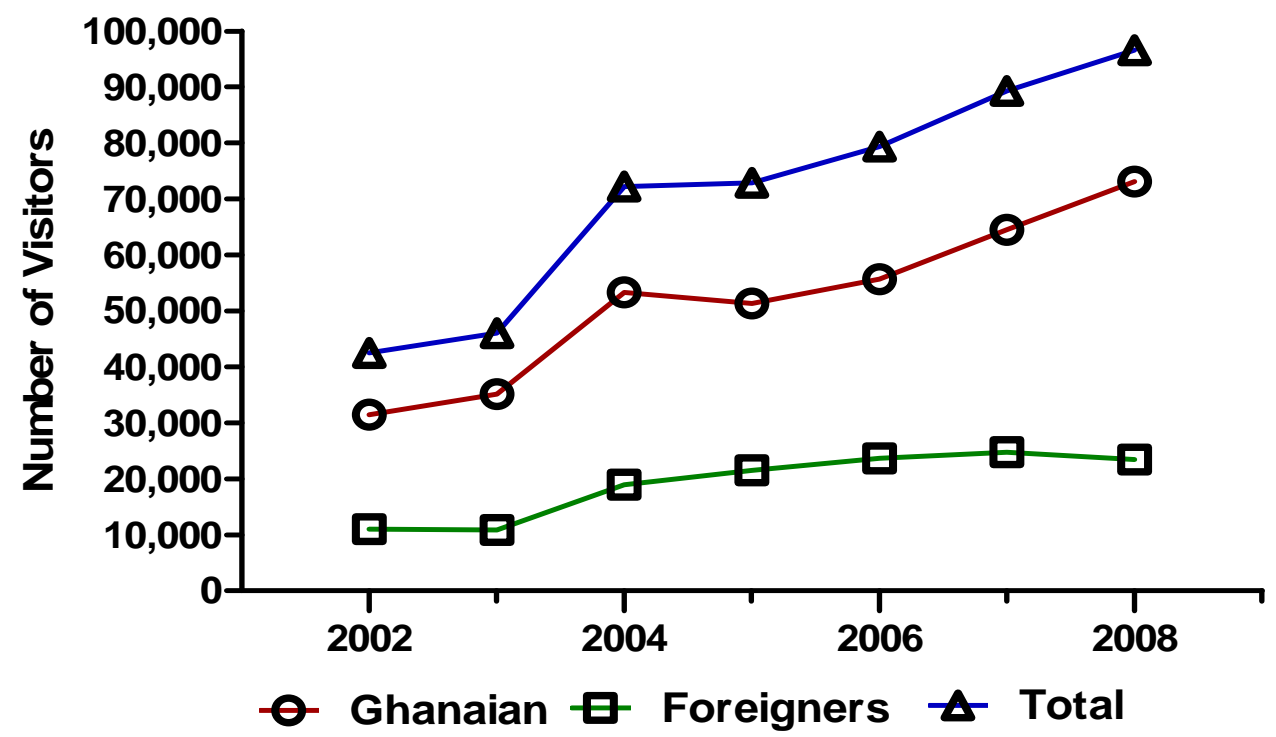

Invariably, it is acknowledged that people visit destinations and particularly touristic destinations in order to fulfil and satisfy some specific needs and desires. Although the Kakum National Park has received considerable media attention in Ghana and has been made a favourite tourist destination due to the canopy walkway, visitors to Kakum have mentioned various motivations for their choice to visit. A tropical forest area in itself offers many opportunities to nature loving visitors. In addition, there is some specific infrastructure provided on site for recreation in the conservation area. The infrastructure includes the famous canopy walkway, nature or hiking trails, camping sheds and a tree platform for the observation of wildlife.

According to the survey, for most $302(71.9 \%)$ visitors, the primary reason for a trip to Kakum is to experience the canopy walk. Hence the general increase in visitations corresponds to the increase in canopy walk as presented in Figure 6.2. The survey, thus confirms the current key role of the canopy walkway as the main visitor attraction in Kakum. The trend indicates that total canopy walk has experienced a steady rise over the period and will most likely continue to be the main attraction until other competing attractions are developed. Forest hiking/nature walk 47 (11.2\%), and Wildlife observation 48 (11.4\%) were the main reasons for other visitors, while for some few, $23(5.5 \%)$, it was a location for relaxation close to nature. 
Figure 6.2 Trends of Visitation in Canopy Walk

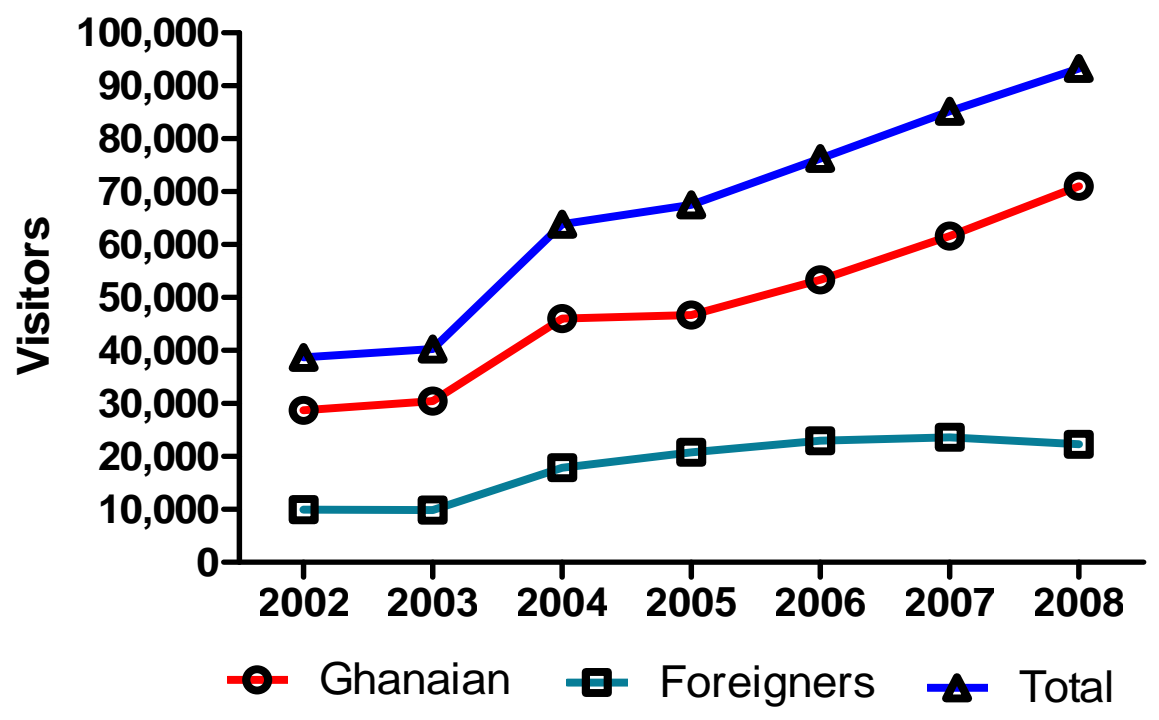

Consistent with these survey results, the numbers of visitors who opted for nature walk have been significantly lower in comparison to the canopy walk as demonstrated in Figure 6.3. The available records from which Figures 6.2 and 6.3 were developed, distinguish origin (Ghanaian or NonGhanaian) and the type of activity; canopy walk or nature walk only. Therefore the trends for the other reasons of visitation could not be derived. Some respondents in the survey however indicated multiple reasons for their visit.

Figure 6.3 Trends of Visitation in Nature Walk

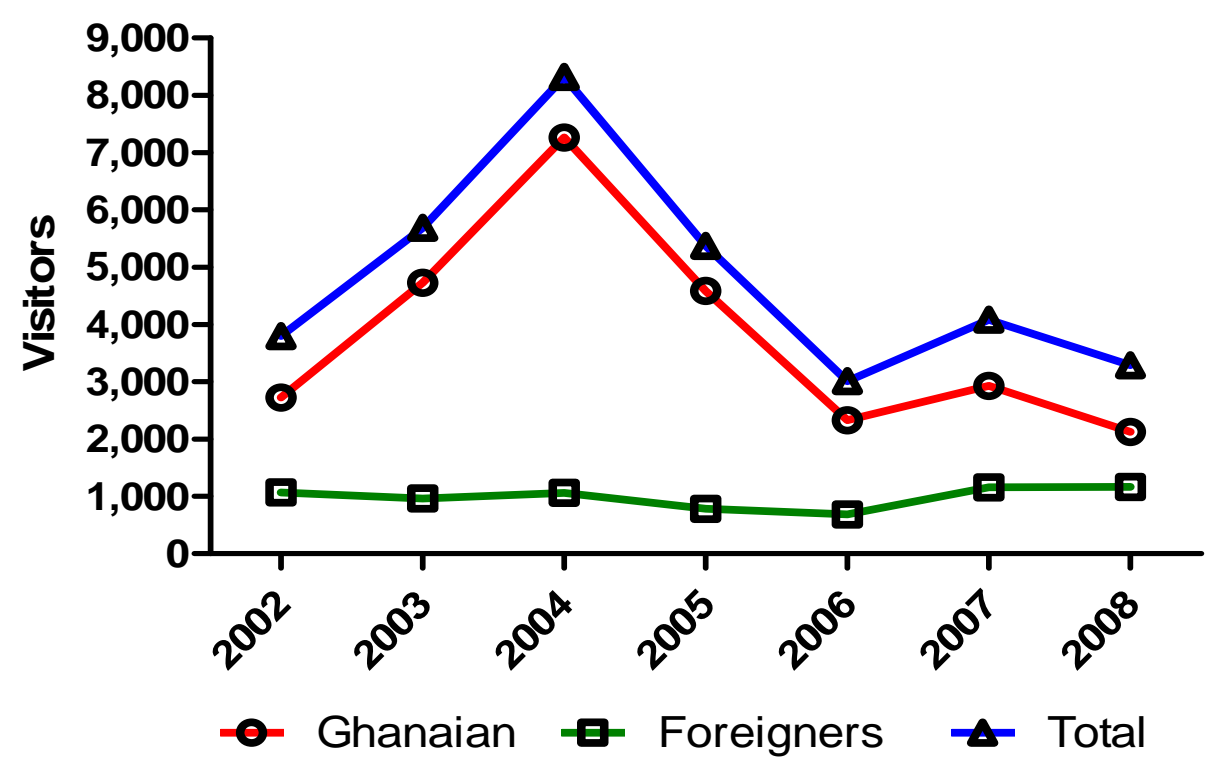


Although, some visitors expected to see wild animals, it is mainly bird watchers that get their wishes fulfilled in a day trip. Most animals in the conservation area are said to be nocturnal and very elusive during day time. Hence in order to sight animals, special arrangements are made to stay overnight and observe these animals at dawn as they move about foraging either in groups or as individuals. For this purpose, a camp has been established near the visitor centre where wildlife enthusiasts pass the night in order to catch a glimpse of the forest animals. The study also observed that some visitors accompany relatives and friends to Kakum but do not take part in any recreational activity in the park. This group of people mostly hung-out at the visitor centre or the picnic areas to just enjoy the serene forest atmosphere.

In all counts, whether by total visitation or activity, the records (between 2002 and 2008) also show that Kakum is mainly patronised by residents of Ghanaians. Irrespective of origin however, the canopy walk has experienced a continuous rise in visitor interest (Figure 6.2). The total visitor participation in canopy walk increased by about 140\% from over 38,700 visitors in 2002 to over 93,280 visitors in 2008 . Within the same period, the nature walk, though with lower numbers, increased until 2004 but then lost the attention of the visitors, which markedly decreased from about 8,300 visitors in 2004 to just over 3,280 in 2008. The visitation numbers of foreigners however remained more or less the same over the period (Figure 6.3).

Even though the canopy walkway continues to attract more visitors, a decline in interest is to be considered like the nature walk. This indicates that how to sustain the interest of visitors and to attract new tourists will soon be a genuine management challenge. In this regards, having information about visitor preferences and their plans would help to decide what additional recreational options might appeal to tourists visiting Kakum and other parts of the country.

\subsubsection{Visitor Itineraries and Preferences}

In developing ecotourism that offers and ensures a lasting experience, it is important to understand visitor preferences and schedules particularly in a predominantly day tour visit as in the case of Kakum. According to Shoval and Isaacson (2007), knowledge of tourist preferences could contribute to policy making, planning and management. They stated that if the spatial and temporal behaviour of the tourists is better understood, it would be possible to adjust the way in which attractions are managed and to improve the marketing strategies in line with the actual needs.

The study therefore also identified other attractions visited before and after Kakum. This enquiry could help to further develop structured and coordinated package tours to facilitate planning of 
activities for enhanced visitor satisfaction. Before visiting Kakum, $72.4 \%(n=416)$ had visited other attractions while $83.3 \%(n=418)$ indicated that they would visit other tourist destinations after the Kakum experience. In differentiating the attractions, the study noted $42.3 \%$ of respondents $(n=293)$ had visited other natural attractions (protected areas /Nature site/Waterfalls) before arriving in Kakum while $38.9 \%$ had visited a monument on their way to Kakum. Subsequently, the tourists were asked to indicate whether they would like to visit other attractions after their experiences in Kakum. While $51.4 \%$ of the respondents $(n=323$ ) indicated an interest to visit a monument, $22.9 \%$ would have liked to visit other protected areas or a Waterfall. Some other respondents (8.2\% and $11.1 \%)$ indicated pre- and post Kakum visits to village communities respectively. The responses suggest the popularity of natural attractions and monuments as the top drivers of tourism in Ghana. Although the interest in pre- or post Kakum visit to village communities are relatively low, when well promoted and offered as an alternative activity, it could offer the opportunity for active involvement of local people and thereby facilitate the participation of the communities in ecotourism management. And for the tourist, the pre- or post Kakum visits to other destinations would offer them an opportunity for the comparison of experiences in different sites, which could sustain their interest and influence their decision for a repeat visit.

\subsubsection{Visitor Opinions}

a) Satisfaction of visitors: Visitor satisfaction is paramount to any management authority if the services and products they offer shall gain popularity and patronage. Likewise, visitor satisfaction is important in promoting ecotourism in a protected area. Zillinger (2007) has shown that there is a common logic in tourist behaviour which is based on criteria such as experience, length of stay or previous information. The tourists' prior knowledge or information and their ability to learn and understand the context in which their experiences are imbedded could play a significant role in determining their level of satisfaction at a particular site or destination. The longer tourists stay in a locality or destination, the better they can make assessment of situations which would influence their judgement and in this case, satisfaction. However, tourists in Kakum are mainly short-time day visitors. Analysis of the survey data revealed that about $78 \%(n=227)$ of non-resident respondents spent less than three hours on site with only $6.6 \%$ spending more than 12 hours. On the other hand, it was observed that over $83 \%(n=186)$ of the respondents resident in Ghana spent less than 3 hour on-site with only about $1.6 \%$ spending more than 12 hours. However, in spite of the relative short time spent on site, respondents were required to indicate on a five-point scale labelled 'not at all satisfied' to 'very satisfied' at points from one and five. The results show that 317 (76\%) of the survey respondents $(n=417)$ were generally satisfied ("enough satisfied" and "very satisfied") with their 
recreational experience. The satisfaction rate within each of the two visitor categories was also high. About $141(76.6 \%)$ of the survey respondents $(n=184)$ resident in Ghana were generally satisfied with their recreational experience in Kakum (Table 6.3). Similarly, 176 (75.5\%) of the non-resident respondents were satisfied with their experience in Kakum (Table 6.4), with an aggregated mean of 3.88 for both categories of respondents on the five-point scale respectively. However, a chi-square test did not show any significant relationship with the demographic characteristics of these respondents except their educational level $\left(\chi^{2}=6.28, p=0.043\right)$.

Table 6.3 Residents' Level of Satisfaction (\%) with Recreational Experience in Kakum ( $n=184)$

\begin{tabular}{cccccc}
\hline $\begin{array}{c}\text { Not at all } \\
\text { satisfied (1) }\end{array}$ & $\begin{array}{c}\text { Not enough } \\
\text { satisfied (2) }\end{array}$ & $\begin{array}{c}\text { Just satisfied } \\
\mathbf{( 3 )}\end{array}$ & $\begin{array}{c}\text { Enough } \\
\text { satisfied (4) }\end{array}$ & $\begin{array}{c}\text { Very satisfied } \\
\text { (5) }\end{array}$ & $\begin{array}{c}\text { Mean } \\
\text { responses }\end{array}$ \\
\hline 2.2 & 4.9 & 16.3 & 56.5 & 20.1 & 3.88 \\
\hline
\end{tabular}

Source: Visitor survey data

Table 6.4 Non-residents' Level of Satisfaction (\%) with Recreational Experience in Kakum ( $n=233)$

\begin{tabular}{cccccc}
\hline $\begin{array}{c}\text { Not at all } \\
\text { satisfied (1) }\end{array}$ & $\begin{array}{c}\text { Not enough } \\
\text { satisfied (2) }\end{array}$ & $\begin{array}{c}\text { Just satisfied } \\
\mathbf{( 3 )}\end{array}$ & $\begin{array}{c}\text { Enough } \\
\text { satisfied (4) }\end{array}$ & $\begin{array}{c}\text { Very satisfied } \\
\mathbf{( 5 )}\end{array}$ & $\begin{array}{c}\text { Mean } \\
\text { responses }\end{array}$ \\
\hline 1.7 & 5.6 & 17.2 & 54.5 & 21.0 & 3.88 \\
\hline
\end{tabular}

Source: Visitor survey data

Among others, one of the objectives for managing Kakum (see section 4.3) is to attract more visitors in order to increase the revenue of the park (Wildlife Department, 1996). An option to increase visitor numbers is through marketing, promotion and delivery of good services including on-site interpretation and education. The sustainability of ecotourism in Kakum, in no doubt, is dependent on continually ensuring visitor satisfaction. However, the analysis in Kakum showed that most, $84 \%$ ( $n=422$ ), of the survey respondents were first time visitors. The remaining $16 \%$ were on their second or third visit within the last ten years. The number of returning visitors was cross-tabulated with origin of visitors in expectation that most of the returning visitors would be the respondents resident in Ghanaian. When all the non-resident visitors were aggregated, the cross-tabulation confirmed that $66.7 \%$ of the returning visitors were domestic visitors.

Some of those returning visitors remarked however that there was not much change, positive in terms of maintaining the forest ecosystem but equally not exciting since there were no additions to the already known recreational options to sustain the excitement and attractiveness of Kakum. It is a 
challenge to maintain the ecotourism potential while ensuring conservation and minimising destruction of the natural resources via infrastructure development which might be regarded as necessary for additional recreation options. Since Kakum is mainly patronised by first time visitors, it is important what kind of information is distributed for marketing Kakum and what kind of experience and messages visitors are carrying along. These information and experience may be passed on to other potential tourists and could create a kind of stereotypic image to condition future visitors. Some studies have indeed indicated that tourist expectations actually start long before the proper visit which means that the tourist's activities at the destination are shaped by priori conceptions (Awaritefe, 2004; Hughes, 2006). The level of satisfaction would therefore depend on the visitors' expectations before the visit and how much of those expectations were actually fulfilled at the destination.

Ecotourism is associated with environmental conservation education and interpretation, and satisfaction with respect to ecotourism is also enhanced through the delivery of quality interpretation by tour guides. In line with this, the study assessed the level of the quality of information and interpretation delivered by the tour guides. The assessment was executed using a five point level of agreement scale as summarised in Tables 6.5 and 6.6 for both the respondents resident in Ghana and those not resident in Ghana. The respondents were asked to mark only one option on the scale representing their level of agreement with statement S3: The level of interpretation by the tour guide was excellent. Same was done for the "hidden connection" exhibition at the visitor centre, statement S2 (Tables 6.5 and 6.6).

Visitor interpretation was observed during the survey and is thought that effective interpretation contributes significantly to visitor on-site behaviour and to visitor satisfaction. Table 6.7 summarises the aspects of visitor interpretation offered by the tour guides during the nature walk or en route to the canopy walk. Respondents were subsequently asked to assess the level of interpretation by their guides with respect to statement (S3). Consequently, 38.9\% and $22.2 \%$ of the resident respondents ( $n=185)$ agreed and strongly agreed that the interpretation delivery by their tour guide was excellent, with an aggregate mean of 3.5 on a five point maximum scale (Table 6.5). With a slightly higher aggregated mean (3.87), $37.3 \%$ and $31.6 \%$ of the non-resident respondents agreed and strongly agreed respectively to statement S3 (Table 6.6). By this, it would be safe to assume that 
Table 6.5 Level of Agreement (\%) by Respondents Resident in Ghana with Factors Related to Satisfaction in Kakum

\begin{tabular}{|c|c|c|c|c|c|}
\hline $\begin{array}{l}\text { Strongly } \\
\text { disagree }\end{array}$ & Disagree & Neutral & Agree & $\begin{array}{c}\text { Strongly } \\
\text { agree }\end{array}$ & $\begin{array}{c}\text { Mean } \\
\text { responses }\end{array}$ \\
\hline \multicolumn{6}{|c|}{ S1: Information about Kakum and tourism activities is easily available. $(n=187)$} \\
\hline 2.1 & 11.2 & 25.1 & 40.1 & 21.4 & 3.67 \\
\hline \multicolumn{6}{|c|}{ S2: The exhibition at the visitor centre is very informative. $(n=183)$} \\
\hline 2.7 & 7.7 & 18.6 & 38.8 & 32.2 & 3.90 \\
\hline \multicolumn{6}{|c|}{ S3: The level of interpretation by the tour guide was excellent. ( $n=185)$} \\
\hline 11.9 & 9.2 & 17.8 & 38.9 & 22.2 & 3.50 \\
\hline \multicolumn{6}{|c|}{ S4: I enjoyed my experience in Kakum. ( $n=187$ ) } \\
\hline 1.6 & 1.6 & 4.8 & 28.3 & 63.6 & 4.51 \\
\hline \multicolumn{6}{|c|}{ S5: I feel I received good value for money. $(n=187)$} \\
\hline 9.6 & 10.2 & 16.6 & 37.4 & 26.2 & 3.60 \\
\hline
\end{tabular}

Source: Visitor survey data; Strongly disagree $=1$, Disagree $=2$, Neutral $=3$, Agree $=4$, Strongly Agree $=5$

Table 6.6 Level of Agreement (\%) by Respondents Resident in Foreign countries with Factors Related to Satisfaction in Kakum

\begin{tabular}{|c|c|c|c|c|c|}
\hline $\begin{array}{l}\text { Strongly } \\
\text { disagree }\end{array}$ & Disagree & Neutral & Agree & $\begin{array}{l}\text { Strongly } \\
\text { agree }\end{array}$ & $\begin{array}{c}\text { Mean } \\
\text { responses }\end{array}$ \\
\hline \multicolumn{6}{|c|}{ S1: Information about Kakum and tourism activities is easily available. $(n=227)$} \\
\hline 0.9 & 9.3 & 28.2 & 42.3 & 19.4 & 3.7 \\
\hline \multicolumn{6}{|c|}{ S2: The exhibition at the visitor centre is very informative. $(n=221)$} \\
\hline 0.9 & 5.9 & 25.8 & 45.7 & 21.7 & 3.81 \\
\hline \multicolumn{6}{|c|}{ S3: The level of interpretation by the tour guide was excellent. $(n=228)$} \\
\hline 2.6 & 7.9 & 20.6 & 37.3 & 31.6 & 3.87 \\
\hline \multicolumn{6}{|c|}{ S4: I enjoyed my experience in Kakum. $(n=227)$} \\
\hline 0.9 & 1.3 & 6.6 & 41.4 & 49.8 & 4.38 \\
\hline \multicolumn{6}{|c|}{ S5: I feel I received good value for money. $(n=230)$} \\
\hline 3.0 & 7.4 & 28.3 & 41.3 & 20.0 & 3.68 \\
\hline
\end{tabular}

Source: Visitor survey data; Strongly disagree $=1$, Disagree $=2$, Neutral $=3$, Agree $=4$, Strongly Agree $=5$

more than half of the visitors to Kakum get adequately educated on the forest and could influence or get visitors to be interested in conservation activities. The "hidden connection" exhibition at the 
visitor centre was designed to help visitors understand the connection between the forest resources and the way of life of the local people and to the larger extent, help preserve the environment in Ghana. And more importantly, why the conservation of these forest resources will enhance and promote the culture and livelihoods of the local people. The visitors were required to indicate the level of agreement, whether the exhibition was informative enough to achieve the purpose. To the statement $\mathrm{S} 2,38.8 \%$ and $32.2 \%$ of the respondents' resident in Ghana agreed and strongly agreed respectively (Table 6.5 ), while $45.7 \%$ and $21.7 \%$ of the non-resident respondents agreed and strongly agreed respectively with the same statement (Table 6.6). The results indicate that more than twothirds of the visitors (both categories of respondents) thought the exhibition is achieving its educational objective.

On availability of information regarding the Kakum Conservation Area, respondents were required to indicate how easy it was to get information (S1) Tables 6.5 and 6.6. This was to check how wide spread Kakum is known and how this could help raise the interest of potential visitors. On availability of information, $40.1 \%$ and $21.4 \%$ of the respondents $(n=187)$ resident in Ghana agreed and strongly agreed with an aggregated mean of 3.67 on a 5-point scale that there was readily available information on Kakum. However, as much as $25.1 \%$ were neutral on the statement. The study further enquired about the sources of information (Table 6.5). On the other hand, $42.3 \%$ and $19.4 \%$ of the non-resident respondents $(n=227)$ agreed and strongly agreed to statement S1 (Table 6.6). The results indicated that one powerful way of promoting the area could be through word-of-mouth. This was confirmed by the sources of information indicated by the respondents. About $44.3 \%$ of the resident respondents $(n=185)$ at Kakum were on an organised trip, while $34.6 \%$ came after personal recommendation or word of mouth. Similarly, while about $36.1 \%$ of the non-resident respondents ( $\mathrm{n}$ $=233$ ) were in Kakum upon word of mouth, $27.9 \%$ came through an organised tour and about $29.2 \%$ of this group of respondents got their information through guide books. Generally, the internet and promotional brochures accounted for only $2.4 \%$ and $0.5 \%$ respectively with respect to the total respondents $(n=418)$. This demonstrates that the use of brochures and the internet as a means of marketing Kakum has not been vigorously pursued. Hence, this emphasises the importance of providing the right information on-site and ensuring a positive experience for tourists visiting Kakum.

In order that visitors become marketers or promoters of Kakum through the medium of word-ofmouth, they should have enjoyed their experience and be very satisfied to take up that role. Hence, the respondents were asked to also agree or disagree with the statement, S4: I enjoyed my experience in Kakum (Tables 6.5 and 6.6). According to the responses, an overwhelming majority 
enjoyed their experience with $28.3 \%$ and $63.6 \%$ of the resident respondents $(n=187$ ) agreeing and strongly agreeing respectively that they enjoyed the experience in Kakum. This resulted in a mean of 4.51 on the 5-point Likert scale (Table 6.5). With respect to the same statement S4, $41.4 \%$ and $49.8 \%$ of the non-resident respondents $(n=227)$ also agreed and strongly agreed respectively, yielding an overall mean of 4.38 on the 5-point Likert scale (Table 6.6). On the issue of receiving good value for money (S5), there was much lower total agreement in comparison to statement S4 (Tables 6.5 and 6.6). Of the 187 resident respondents, $37.4 \%$ agreed and $26.2 \%$ strongly agreed to the statement as indicated in Table 6.5. The non-resident respondents also expressed less total agreement with the issue of receiving value for money (S5). As indicate in Table 6.6, about $41.3 \%$ and $20.0 \%$ agreed and strongly agreed respectively to S5 (Table 6.6). Nonetheless, the level of agreement with enjoying the experience is consistent with the general level of satisfaction as expressed by the respondents.

Table 6.7 Summarised Aspects of Interpretation Offered by Tour Guides

\begin{abstract}
Ecological interpretation
The ecological interpretation describes the inter-relationships that exist between the species within the conservation area. The guide tries to explain some of the symbiotic relationships between the flora and fauna. Particularly the importance of some animal species in seed dispersal and facilitation of tree seedling germination The ecological focus was found to contribute to visitor awareness of the importance of their ecological surroundings, which can be translated into pro-environmental behaviour in the visitors.
\end{abstract}

\begin{abstract}
Human impact on the environment
Visitors were informed about the human uses of the resources and how it has impacted on the ecology. Human actions are inextricably integrated in ecological landscape. The past and present actions of humans have helped shaped ecosystems and areas that are visited as ecotourism sites. The attention of visitors is drawn to the fact that the area had previously been designated for timber extraction and local people had also extracted various non-timber forest products from the area. However, the visitor's attention is directed to the point that current human actions may influence and impact upon the ecosystem. Hence the need to observe regulations concerning visitor behaviour and actions that may deteriorate the area.
\end{abstract}

\title{
Advocacy for conservation
}

Advocacy for environmental conservation is generally a prominent feature of the ecotourism concept and operations. Although biodiversity conservation is a topical issue in Ghana, this aspect of the interpretation does not stand out. All the guides that were observed did not focus on advocacy but a few of them only mentioned it in passing. This objective of ecotourism may be achieved using both direct interpretation and provision of printed materials on-site.

Source: Field data collection (2009).

Consequently, the study enquired how many of the respondents would recommend Kakum to other potential visitors. With the level of expressed satisfaction, the majority $383(91.6 \%)$ of the total 
respondents stated that they would recommend Kakum as a "must visit" ecotourism site in Ghana. Only $35(8.3 \%)(n=418)$, a majority $(26)$ of whom being non-resident respondents, stated that they will not recommend Kakum as ecotourism site. When the respondents were grouped, it was observed that over $95 \%$ of the resident respondents $(n=187)$ and about $88.7 \%$ of the non-resident respondents $(n=231)$ will recommend Kakum. Further Chi-square test revealed that gender $\left(\chi^{2}=\right.$ 9.519, $p=0.002)$, origin of visitor $\left(\chi^{2}=5.591, p=0.018\right)$ and those visiting in a group $\left(\chi^{2}=4.706, p=\right.$ 0.030 ) had significant relationships with readiness to recommend Kakum to others. That is, more females, over $95 \%(n=246)$ compared to about $87 \%$ males $(n=172), 95.2 \%$ residents against $88.7 \%$ non-residents, as well as $78 \%$ of those visiting in a group $(n=412)$ would recommend Kakum to other potential visitors. In spite of this however, more than half of the total respondents 229 (54.1\%) expressed their disagreement with the restrictions instituted by the management authorities on movements within the park.

b) Additional recreational options: A considerable number of respondents, apart from registering their desire to have a free access to the park, expected to have additional recreational activities or facilities in the conservation area (Tables 6.1 and 6.2). This demand was more pronounced among the resident respondents $49.7 \%(n=185)$ and rather distinct concerning the younger visitors under 20 years, as compared to $33.3 \%(n=219)$ of the non-resident respondents. However, the majority of the respondents in this category who expressed the need for additional recreational activities in Kakum belong to the $20-37$ age-group. The most cited activity was wildlife observation and tracking posts $(56.8 \%)$. Some $10.7 \%$ of the respondents proposed longer hiking or unguided tours while $14.2 \%$ wanted to have more involvement with traditional or culturally related activities. Another $10.1 \%$ desired hands on experience with traditional handicraft and other conservation related education activity. The analysis further determined the importance of the demand for 'more options for recreation' and how it was influenced by the demographic variables. A summary of Chi-square test of the relationships are presented in Tables 6.1 and 6.2. Apart from the already mentioned coherences, the opinion of visitors in family groups, age occupational status and the level of education, were significantly related to voting for more recreational activities (Table 6.1). Similarly, the age group and being in a family group among the non-resident respondents were significantly related to the desire for additional activities in the conservation area (Table 6.2). 


\subsection{Discussion}

In spite of its fame, Kakum virtually provides only one key attraction - the canopy walkway. Nonetheless, the canopy walk by itself turned out to have limited effect on attracting similarly high number of visitors from overseas as evident in the visitor records presented in Figures 6.2 and 6.3. Although the number of foreign and non-resident visitors has more or less doubled during the first years after the opening of the canopy walk way, it has to be admitted that this development quickly weakened and seems to have reached a level of saturation in 2008. Further, their number is by far lower than that of the domestic or visitors resident in Ghana. Almost all of the non-resident visitors do go for the canopy walk while a more or less constant but smaller proportion of them also enjoy the nature walk. In contrast to this, the explicitly more domestic visitors have more than doubled over the same period of time and this development, for now, does not show any trend of declining. Obviously not all of them afford the canopy walk while the interest to participate in the nature walk has rapidly decreased since 2004 . Nonetheless a prevailing general expression of satisfaction by all visitors could be ascertained, due to the attraction of the most appreciated canopy walkway. However a common request for additional options for recreation opportunities has to be considered. This is a challenge to improve the Kakum experience. In this context it is also particularly worth noting that a simplistic measure of satisfaction could be misleading and seduce managers to be complacent. Though respondents expressed general satisfaction, the five-point satisfaction scale revealed that the overall mean was 3.88 out of 5.00 maximum for both the resident and non-resident respondents. The majority of respondents were between "just satisfied" and "enough satisfied" which is certainly not overwhelming. Most of the younger visitors demanded additional recreational options. This means that the management authorities still have much to do in order to further improve on satisfaction.

After the canopy walk or a nature walk, there is virtually nothing more to do and keep active. Therefore visitors immediately leave the site for other places. Observations revealed that after registration, visitors are given a guided tour (canopy walk or nature walk) but they do not spend more time at the site thereafter. It is a routine for every visitor to follow the pre-determined "enter park - canopy walk - leave park" sequence. Such uniform procedure could be broken by developing additional attractions or activities even at the visitor centre. The following section will highlight some viable alternatives and their implications. The responses from the survey have indicated that many tourists would appreciate some additional recreational options in Kakum. If anyone is unable to do the canopy walk, the alternative is the nature walk which also attracts more of the domestic than the non-resident/foreign visitors. But Figure 6.3 also indicates that it has lost a great part of its popularity in comparison to the canopy walk and with respect to the total number of visitors. Obviously, the 
current nature walk facility is not adequate in providing the excitement, the socio-ecological learning opportunity or the thrill visitors might expect from a visit to a protected area. The current nature walk is usually a guided walk on a restricted hiking trail in the park which is particularly interesting for some students and the curious foreign visitors but not for the Ghanaian visitors who might be looking for something unique. Also, the foreign visitor might be keen on seeing wild animals in their natural habitat. The need to provide alternative activities at Kakum is particularly urgent given the fact that the canopy walk itself does not take long, just a few minutes to complete, depending on the group size.

Visitors who expected to see wildlife expressed their disappointment for not sighting animals. This is not surprising since scattered information always mentions and boasts of the varied and numerous animal species in Kakum but fails to iterate that most of the animals dwelling in the conservation area are nocturnal and the few that have diurnal behavioural characteristics are also very elusive making in difficult to sight them in such a dense tropical rainforest on a day-time trip.

Ecotourism's role in facilitating conservation education and awareness could be achieved through quality interpretation and mounting exhibitions related to nature conservation. The study noted that about $29 \%$ and over $32.6 \%$ of the resident and non-resident respondents respectively (Tables 6.5 and 6.6) did not judge the "hidden connection" exhibition as informative enough. For these respondents, it could mean that the exhibition does not adequately convey the importance of the resources and how it influences the culture and livelihoods of the local people. Neither does it emphasise the importance of nature conservation. Likewise, about $40 \%$ and $31 \%$ of the resident and foreign resident respondents also indicated that their tour guide was not good in interpretation. The opinion of these respondents could be a result of poor delivery in terms of content and coherence or the inability of the guide to make the interpretation more interesting. Nevertheless, the mean scale points concerning the level of agreement for the exhibition and interpretation were 3.90 and 3.50 respectively for the domestic respondents (Table 6.5), while the foreign resident respondents recorded 3.81 and 3.87 respectively (Table 6.6 ). The means indicated principle agreement to the corresponding statements. However, it is important to note that about one fifth of the respondents were neutral in both scale items. As has been indicated earlier, neutral responses tend to connote negative response and therefore the delivery on both scale items are worth improving to enhance conservation and awareness creation among visitors.

The study also observed that Kakum has a low visitor return rate. The low return rate $(16 \%$, based on the respondents) could indicate that the tourists probably only get to satisfy their curiosity to experience the canopy walk but the limited variety of recreational options does not give them 
enough motivation to repeat the visit. However, the motivation on the side of management to increase visitations also bears great risks which can cause off-site impacts such as i) increased local auto fuel consumption since the site is not in easy reach to the average visitor without the use of cars or buses; ii) generation of solid waste (rubbish or garbage) because visitors might take various items and food for their trips; iii) water and air pollution, or even iv) reclamation of land for other infrastructure (example, clearing of forests for parking, catering or even accommodation). On the other hand, this could also be a development opportunity for nearby communities.

The foregoing emphasises that ecotourism can generate some negative impacts and therefore managers have to be aware of what levels of impact are acceptable, the relationship between the use and impact level and how these relationships might affect management activities. It is acknowledged that the question of acceptable level is relative and as well debatable but more importantly, difficult to evaluate. The answer is by far more a normative or political position or decision rather than an absolute technical consideration. Nonetheless, it is still pertinent to hold visitor satisfaction paramount while ensuring that conservation objectives are not compromised.

\subsection{Conclusion and Recommendations for Management}

According to the survey, the primary reason of most of the visitors in Kakum is to experience the canopy walk. This is consistent with the existing visitation records shown in Figures 6.2 and 6.3. The majority of visitors in Kakum are first time visitors of whom most are below 38 years, thus suggesting that Kakum is mostly patronised by the youth. In that regard, it becomes even more challenging to put up activities to meet their demand and to continue to attract such group of people. Accordingly, Shoval and Isaacson (2007) have noted that understanding the temporal and special behaviour of tourist would make it possible to adjust the way in which attractions are managed and to improve on marketing in line with their needs.

The study thus identified visitation itineraries of the survey respondents in order to explore the possibility of further developing more attractive package tours to enhance visitor experience. The analysis indicated that in spite of the majority (78\%) spending less than three hours on site, 317 $(76 \%)$ of the overall respondents $(n=417)$ were generally satisfied with the recreational experience in Kakum. Most of the respondents were in organised tour or visited by virtue of word-of-mouth. This buttresses the importance of ensuring a positive recreational experience on these first time visitors who might want to return or recommend Kakum to other potential visitors, particularly where the study has observed a low visitor return rate. As a confirmation of their satisfaction, 383 
(91.6\%), considering both categories of respondents, would recommend Kakum as a must visit destination.

In spite of the seemingly high satisfaction, current recreational activities do not allow many visitors to stay longer than three hours to maximise experiential satisfaction. The monotonously short visitation cycle could be broken by providing additional facilities. In this way the visitors are more likely to maximise utilisation of other facilities and also create the opportunity for the management staff to transmit their conservation messages across to the visitors.

Although the respondents were generally satisfied with the experience in Kakum, they did indicate their desire for additional recreational options. Hence, to ensure continual visitor satisfaction, the concerns for more recreational opportunities would need adequate attention. Efforts to establish hideouts or platforms at appropriate locations in and around the park for viewing tropical forest animals would constitute another potential attraction alongside the canopy walkway. Besides creating additional recreational options in the park, organised visits to adjacent communities and nearby farms (farm visits) would expose particularly non-Ghanaian visitors to rural life in Ghana. This could offer an opportunity for the curious foreign visitors to learn first-hand from the local people about rural life in Ghana.

As an endorsement and potentiality of village and farm visits, a survey of some village communities around the Kakum Conservation Area revealed that local people would like ecotourism activities extended to their communities (Fiagbomeh and Bürger-Arndt, 2010). This could offer further opportunities to identify special locations for wildlife viewing close the communities, facilitate the extension of ecotourism activities and provide appreciable benefits to the local people. Such initiatives have the potential to win the support of local people and thus enhance conservation efforts within the protected area.

In order to add value to recreational or ecotourism experience in Kakum, efforts could be made to habituate some of the animals within specific areas of the park. Hence with the aid of observation posts, visitors could observe some of the elusive forest animals. While it is an objective to provide diversity in visitor experience, care must also be taken not to compromise sensitive habitats in the conservation area. The siting of appropriate wildlife observation posts close to nearby communities could turn around the lower interest by tourists visit to village communities, and could provide the avenue to engage village communities in managing ecotourism activities which will enhance local appreciation of conservation initiatives while facilitating further development of the local communities. Such initiative would be in fulfilment of an important tenet of ecotourism, namely 
community participation and benefit sharing, which is presently non-existent in Kakum (Fiagbomeh and Bürger-Arndt, 2010). It is however recognised that habituating wildlife will not be an easy task and could also open up a whole debate on other possible implications for the wildlife and the general conservation of the area. Granted that this option is given some merit, Kakum would continue to be the most patronised park in Ghana.

Request for longer hiking or unguided tours could also offer added value of adventure in a tropical forest for the adventurous and nature loving visitors. This is particularly worth to consider taking into account that most visitors to Kakum according to the survey are still young (over $77 \%$ below 38 years). They have the energy, curiosity and are adventurous. For such provisions, the visitor would have many opportunities for learning and appreciating the diverse ecological structure of Kakum. Again, it would increase the possibility of sighting wild animals in their natural environment. For the visitor, it should be fulfilling and also providing more justification for the cost of travel to the site. However, this would mean opening up other parts of the park for visitors by constructing longer and alternative hiking trails. This could lead to encroachment on fragile and tranquil areas which eventually might impact on the wildlife species where there are no adequate mechanisms to monitor and control visitor activities.

Further, consideration could be given to adding more education and interpretive signs at the waiting areas, and create some shorter trails purposely for unguided tours. This would entice visitors to stay longer and arouse their interest to explore nature with the associated cultural influences presented in and around the Kakum Conservation Area. Again, it is worth considering establishing wildlife observation spots close to village communities. This has the potential to make Kakum even more attractive for tourists and at the same time would create the platform to involve village communities in the management of ecotourism and conservation initiatives in the area. 


\subsection{References}

Awaritefe, O. 2004. Motivation and other Considerations in Tourist Destination Choice: A Case Study of Nigeria. Tourism Geographies 6(3):303-330

Baker, D. A. and Crompton, J. L. 2000. Quality, Satisfaction and Behavioral Intentions. Annals of Tourism Research 27(3): 785-804

Boyd, S.W. and Butler, R.W. 1996. Managing ecotourism: an opportunity spectrum approach. Tourism Management 17(8): 557-566

Burton, F. 1998. Can ecotourism objectives be achieved? Journal of Sustainable Tourism 6(3): 755758

Chirgwin, S. and Hughes, K. 1997. Ecotourism: The participants' perceptions. The Journal of Tourism Studies 8(2): 2-7.

Dorfman, P. W. 1979. Measurement and meaning of recreation satisfaction: A case study in camping. Environment and Behavior 11 (4): 483-510

Ellis, C. L. and Vogelsong, H. 2002. Assessing indicators relating to overall tourist satisfaction of ecotourim development in Eastern North Carolina. Proceedings of the 2002 Northeastern Recreation Research Symposium. GTR-NE-302. p 52 - 57

Fiagbomeh, R. F. and Bürger-Arndt, R. 2010. Local Community's Perceptions and Attitudes towards Protected Areas and Ecotourism Management - the case of Kakum Conservation Area, Ghana. In: Hamzah, A. (ed.). 2010. Conference Proceedings: Academic Papers - Moving Up Ecotourism along the Value Chain. Royal Belum $2^{\text {nd }}$ World Ecotourism Conference WEC 2010, Kuala Lumpur Convention Centre, Malaysia 8-10 July 2010. pp 11 - 30

Geva, A. and Goldman, A. 1991. Satisfaction Measurement in Guided Tours. Annals of Tourism Research 18(2): 177-185

Gitelson, R. J. and Crompton, J. L. 1984. Insights into the repeat vacation phenomenon. Annals of Tourism Research 11: 199 - 217

Hughes, G. 2006. Tourism and the Geographical Imagination. Leisure Studies 11(1): 31-42

Hvenegaard, G. T. 1994. Ecotourism: a status report and conceptual framework. Journal of Tourism Studies 5(2): 24-35

Mazursky, D. 1989. Past Experience and Future Tourism Decisions. Annals of Tourism Research 16: $333-344$

Oppermann, M. 2000. Tourism destination loyalty. Joumal of Travel Research 39:78-84

Orams, M.B. 1995. Towards a more Desirable form of Ecotourism. Tourism Management 16(1):3-8

Pearce, P. L. 1988. The ulysses factor: Evaluating Visitors in Tourist Setting. New York, Springer Verlag. $120-127$

Reynolds, P C. and Braithwaite, D. 2001. Toward a conceptual framework for wildlife tourism, Tourism Management 22(1): 31-42

Ryan, C. 1995. Researching Tourist Satisfaction: Issues, Concepts, Problems. London: Routledge 
Shoval, N. and Isaacson, M. 2007. Tracking tourists in the digital age. Annals of Tourism Research 34(1): 141-159

Whipple, T. W. and Thach, S. V. 1988. Group tour management: Does good service produce satisfied customer? Journal of Travel Research 27(2): 16-21

Wight, P. 1993. Ecotourism: ethics or eco-sell? Journal of Travel Research 31(3): 3-9

Wight, P. 1996. North American Ecotourism Markets: Motivations, Preferences and Destinations. Journal of Travel Research 35(1): 3-10

Wildlife Department. 1996. Kakum National Park and Assin Attandanso Resource Reserve. The Management Plan. Wildlife Department Accra

Zillinger, M. 2007. Tourism Routes: A Time-Geographical Approach on Germany Car-Tourist in Swede. Tourism Geographies 19(1):64-83

Yuksel, A. 2001. Managing Customer Satisfaction and Retention: A Case of Tourist Destinations, Turkey. Journal of Vacation Marketing 7 (2): 153-168 


\section{Chapter Seven: Local Community's Perceptions of Impacts and their Attitudes Concerning Ecotourism in the Kakum Conservation Area - Opportunities for Participation}

\subsection{Introduction}

The implementation and management of ecotourism is thought to provide justification to support nature conservation efforts as it is in charge of creating and maintaining sustainable environment for both local people and tourists. Ecotourism, in this respect, is also advanced as a strategy to help address economic and social problems in local communities, especially those peripheral to conservation or ecotourism destination areas. This is because ecotourism is regarded as a revenue generating activity both on a local and national level (Kuvan and Akan, 2005). However, to achieve the object of addressing economic and social problems via management, communities should be aware of and must have positive attitude towards ecotourism development and management. A lack of community awareness and positive attitudes is likely to affect the overall outcome of ecotourism in any given destination.

While conservationists want maximum protection of natural resources and the tourism industry seeks pristine and attractive sites; meeting their combined demands means that local or resident people do risk losing the resources use rights they hitherto have traditionally used for food, shelter and or commerce. Often, local people living adjacent to ecotourism destinations or protected areas used for such purposes, have long-standing relationships with the area and the resources therein. Hence their perceptions and attitudes should not be overlooked when implementing and managing ecotourism in such areas.

A review of literature suggested factors that influence such attitudes and perceptions in the broader context of tourism and grouped into two: intrinsic and extrinsic factors (Weaver and Lawton, 2001). Among the intrinsic factors, economic benefits from tourism emerge as one of the significant variables underlying residents' positive perceptions of the impacts and favourable attitudes toward tourism development in most studies (Haralambopoulas and Pizam, 1996; Korça, 1998; Snaith and Haley, 1999). Other studies (Mehta and Heinen, 2001; Jim and Xu, 2002; Bandara and Tisdell, 2003) also noted that demographic factors can significantly influence attitudes of local people. According to these studies, local residents who support tourism development in an area are generally the young (Haralambopoulas and Pizam, 1996; Weaver and Lawton, 2001), affluent (Haralambopoulas and Pizam, 1996), and the educated (Koçra, 1998; Teye, et. al., 2002). Likewise, there is some evidence that male residents are more supportive of tourism compared to their female counterparts (Mason 
and Cheyne, 2000). Furthermore, according to Andereck and Vogt (2000) in a situation where both sexes express support for the development of tourism in an area, they give different reasons for their support, which suggests differences in perceptions and opinions based on gender differences. Some studies have also sited ethnicity as another demographic factor that influences local resident attitudes (Liu and Var, 1986; Besculides, et. al., 2002), particularly in relation to cultural impacts of tourism. Nonetheless, while some researchers have reported significant differences between respondent characteristics associated with positive or negative opinions of tourism in an area, others (King, et. al., 1993; Ryan and Montgomery, 1994) have concluded that socio-demographic variables have no, or negligible contribution in identifying the underlying factors in respondent attitudes. The discrepancy in these research findings can be attributed to the unique characteristics of the local residents at the sites where each study is conducted, as tourism impacts are shaped by site specific conditions under which tourists and local residents interact (Tosun, 2002).

In spite of the above referenced studies, it is admissible that the impacts of ecotourism on local people and communities are difficult to measure, as, to a large extent, they are indirect. Consequently, the purpose of this study is to examine local communities' perceptions of the impacts and attitudes towards ecotourism and their level of interest to participate in its management and provision of service to the tourists. Specifically the study i) examines the perceptions of ecotourism impacts on the community and livelihoods; ii) identifies the barriers and impediments that prevent the local people from actively taking part in ecotourism activities and management.

\subsection{Methodology}

\subsubsection{Sampling and Data Collection}

The basis of this study was a survey of 141 households conducted in eight village communities (namely: Abrafo, Afeaso, Antwikwaa, Bobi, Kruwa, Mfuom, Mesomagor, and Obengkrom) close to the boundary of the Kakum Conservation Area (Figure 4.2). The selection of communities was based on whether they have or had any influence on the conservation area with regards to their relevance for ecotourism activities in Kakum or the use of natural resources in sustenance of local livelihood. That is, all the communities involved in the survey are situated close to the Kakum National Park: the southern portion of the conservation area (Figure 4.2) where all ecotourism activities take place. These eight communities can be regarded as characteristic representation of the numerous communities within five to six kilometres distance from the boundaries of the conservation area. People in the sampled communities are both indigenous and migrants who originate from different 
parts of Ghana and would have different perspectives, perceptions and attitudes towards the conservation area and ecotourism.

The household questionnaires (Appendix 1) were administered to household heads or adult (male/females) representatives in order to gather both demographic information and their perceptions of the impacts of ecotourism. The questionnaire mainly consisted of two types of questions: 'close-ended' and 'open-ended' questions. Generally, close-ended questions required answers of two types: dichotomous questions required a Yes/No or Approve/Disapprove answers while other questions required the respondent to choose among alternative answers (for example Agree/Indifferent/Disagree or Negative effects/No effect/Positive effect). Open-ended questions required respondents to give explanation to situations or reasons for a chosen response.

In addition to the household survey, complementary data collection was conducted through focus group discussions and interviews with elders and opinion leaders of the sampled communities. These techniques were adopted to gather information on the perceptions of ecotourism impacts in the conservation area and the adjacent communities. Through this, general and historical information about the communities, including communal structure and social organization, as well as the local community's involvement in ecotourism were gathered.

The communities included in the study were visited several times to pre-arrange for meetings with the chiefs and elders. The first visit to each community was purposely introductory, to meet the chief or the community leaders to condition them for the study. Through such meetings, the residents were informed about the study and the impending group discussions. The purpose of the study was explained at these meetings and subsequent dates were fixed to hold the group discussion for each community. The group discussions were originally meant to be segregated into male and female groups. However, it was not possible to hold such separate discussions because very few women responded to the call for group discussions in their community. That notwithstanding, the women present at the meetings together with men were equally active and made useful contributions. The prevailing rural protocol was observed in each community. Therefore in all cases, the meetings and discussions were very informal.

\subsubsection{Data Analysis}

Data analysis was performed with the Statistical Package for the Social Sciences (SPSS) ver. 16 at the significance level of $p<0.05$. Logistic regression was used to determine the importance of various 
demographic factors related to ecotourism. The beta value (B), standard error (SE), chi-square statistic $\left(\chi^{2}\right), p$-value and exp. Beta value $(\operatorname{Exp}(B))$ for each input variable are presented in Tables 6.3. For the overall model, Chi-square $\left(\chi^{2}\right), p$-value and Nagelkerke $R$ Square $\left(R^{2}\right)$ are also presented (Landau and Everitt, 2004; Pallant, 2005). Responses to the close-ended questions were re-coded as binomial responses (yes/no, agree/disagree) to develop dependent variables in the estimation of logistic regression models. The re-coding of respondents' responses was based on the assumption that a neutral response could indicate a potential negative attitude or perception (Newmark, et. al., 1993; Gillingham and Lee, 1999). Therefore neutral responses were re-coded into negative responses. Independent variables used in the estimation of the logistic regression models included: gender (Sex), age group (Age), educational level of respondent (edu), community cluster (Comty), and ownership of land (land). Descriptive statistics were also employed to give summaries of the characteristics of respondents and other related parameters under consideration.

The communities were grouped into three clusters based on location for the analysis. Cluster one consists of Abrafo and Mfuom, located at the South West edge of the conservation area (Figure 3.2) along the major road which runs along the main entrance, and much closer to the centre of ecotourism activities. Cluster two consists of Afeaso, Antwikwaa and Bobi. Antwikwaa is located along the Central West boundary, while Afeaso and Bobi are located at the North West edge of the Kakum National Park portion of the conservation area (Figure 4.2). These communities are accessed by surfaced untarred roads and far removed from the centre of activities. Cluster three is made up of Kruwa, Mesomagor and Obengkrom. These communities are locate along the eastern boundary, with Mesomagor at the North East of Kakum National Park, while both Kruwa and Obengkrom are located are the South East. Mesomagor is home to the Bamboo orchestra group that occasionally perform at the visitor centre to the delight of tourists. The community is also close to the tree platform which offers opportunity to observe the forest elephants in Kakum. Communities of cluster three are also accessed by untarred road. Both Kruwa and Obengkrom like community cluster two, generally have minimal or no contacts with tourists.

\subsection{Results}

\subsubsection{Profile of Respondents}

There were 75 (53.2\%) female respondents as opposed to $66(46.8 \%)$ male respondents (Table 7.1$)$. The mean age of the respondents was 48.2 years, with the oldest being 72 years and the youngest being 20 years. 
On the average, household respondents have lived for 35 years in the community although this varied greatly with the oldest respondent having lived in a community for 65 years and the newest for about eight years. Household sizes varied from 2 to 16 members with a mean of 8.01 persons as compared to the general mean of 4.4 persons for the administrative region (Ghana Statistical Service, 2005). With regard to education, 95 (67.4\%) had attained up to Junior Secondary School (JSS) and 45

Table 7.1 Demographic Characteristics of Community Respondents

\begin{tabular}{|c|c|c|c|c|c|}
\hline \multirow[t]{2}{*}{ Characteristics } & \multirow[t]{2}{*}{ Group } & \multicolumn{3}{|c|}{ Community Cluster } & \multirow[t]{2}{*}{ Total (\%) } \\
\hline & & 1 & 2 & 3 & \\
\hline \multirow[t]{3}{*}{ Age Group } & $<30$ years & 6 & 1 & 0 & $7(5.0 \%)$ \\
\hline & $30-50$ years & 31 & 20 & 26 & $77(54.6 \%)$ \\
\hline & $>50$ years & 19 & 21 & 17 & $57(40.4 \%)$ \\
\hline \multirow[t]{2}{*}{ Gender } & Male & 21 & 23 & 22 & $66(46.8 \%)$ \\
\hline & Female & 35 & 19 & 21 & $75(53.2 \%)$ \\
\hline \multirow{3}{*}{$\begin{array}{l}\text { Educational } \\
\text { Level }\end{array}$} & Illiterate & 8 & 14 & 23 & $45(31.9 \%)$ \\
\hline & $\leq \mathrm{JSS}$ & 47 & 28 & 20 & $95(67.4 \%)$ \\
\hline & $\geq$ SSS & 1 & 0 & 0 & $1(0.7 \%)$ \\
\hline
\end{tabular}

Community cluster: 1=(Abrafo, Mfuom); 2=(Afeaso, Antwikwaa, Bobi); 3=(Kruwa,

Mesomagor,Obengkrom); JSS = Junior Secondary School; SSS= Senior Secondary School

(31.9\%) were illiterates (Table 7.1). This indicates that educational attainment in the study area is low. With regard to age, a majority of the respondents $77(54 \%)$ were in the $30-50$ year group followed by the $>50$ and $<30$ year groups respectively.

Table 7.2 Characteristics of Study Communities (++ = sufficient; + = some possibility; 0 = lacking; $F=$ farming; $L=$ limited; $\mathrm{PA}=$ Protected Area)

\begin{tabular}{|c|c|c|c|c|c|c|c|c|}
\hline $\begin{array}{l}\text { Community } \\
\text { characteristic }\end{array}$ & Abrafo & Afeaso & Mfuom & Antwikwaa & Obengkrom & Mesomagor & Kruwa & Bobi \\
\hline Health facility & 0 & 0 & 0 & 0 & 0 & 0 & 0 & 0 \\
\hline $\begin{array}{l}\text { Water supply } \\
\text { facility }\end{array}$ & ++ & + & + & + & + & + & ++ & + \\
\hline $\begin{array}{l}\text { Education } \\
\text { facilities }\end{array}$ & ++ & ++ & ++ & + & 0 & ++ & + & + \\
\hline $\begin{array}{l}\text { Economic } \\
\text { possibilities }\end{array}$ & ++ & + & ++ & + & 0 & + & + & + \\
\hline $\begin{array}{l}\text { Main liveli- } \\
\text { hood activities }\end{array}$ & $\mathrm{F}$ & $\mathrm{F}$ & $\mathrm{F}$ & $\mathrm{F}$ & $\mathrm{F}$ & $\mathrm{F}$ & $\mathrm{F}$ & $\mathrm{F}$ \\
\hline $\begin{array}{l}\text { Vicinity to } \\
\text { market }\end{array}$ & ++ & + & ++ & 0 & 0 & 0 & + & 0 \\
\hline $\begin{array}{l}\text { Benefits from } \\
\text { PA }\end{array}$ & $\mathrm{L}$ & L & L & $L$ & L & L & L & L \\
\hline
\end{tabular}

The general state of infrastructure and facilities in the sampled village communities are presented in Table 7.2. There are no health facilities in any of the communities. Residents of the communities 
have to travel to bigger towns when there is the need for medical attention which is often difficult due to poor roads and irregular transportation services.

With the exception of Obengkrom, all the communities have educational facilities at least for the primary education of their children. All the communities also have some form of drinking water source (dug-out wells). However, according to the group discussions, these are not adequate to supply water to the entire communities particularly during the dry season where some tend to dry out. During such times, residents of the affected communities depend on the stream for water.

With respect to market and economic activities, four out of the eight communities have direct access to the market to sell their farm produce. While Afeaso and Kruwa make use of designate open space for weekly marketing of their produce, Abrafo and Mfuom have built-up sheds for daily marketing purposes. Residents of the remaining communities travel weekly to other neighbouring communities for the purpose of buying and selling various produce.

\subsubsection{Perceived Impacts of Ecotourism}

The household surveys did not give a clear confirmation of the impact of ecotourism on livelihood since as much as $39.7 \%$ were neutral (did not express any opinion), while $33.3 \%$ of the respondents had no idea on what the impact of ecotourism was on their livelihood. In consideration of the assumptions made in other studies (Newmark, et. al., 1993; Gillingham and Lee, 1999), all these respondents (73.0\%) rather have negative perceptions concerning the impacts of ecotourism on their livelihood considering that ecotourism does not contribute positively to their livelihood. However, only $5.7 \%$ and $7 \%$ explicitly expressed that the impact of ecotourism was bad and very bad respectively (Figure 7.1) on their livelihood. At least, logistic regression results (on the statement/question 1: would you say ecotourism is important or unimportant to you?) confirm ( $\chi^{2}=$ $30.98, p<0.0001)$ that ecotourism plays no important role in the livelihoods of local people as indicated by $82(58.2 \%)$ of the respondents (Table 7.3$)$. Consistent with the survey and group discussions, Figure 7.1 reflects the general opinion that ecotourism in KCA has not been beneficial to the adjacent communities.

Apart from community cluster one (Abrafo and Mfuom) which have slightly improved infrastructure, all other communities are poorly equipped. Both Abrafo and Mfuom lie on a main asphalt road and therefore have easy access to transportation which is a challenge to the other communities. They also have a built-up market place and better facilities for both basic education and sources of water 
for domestic use. A chi-square test of a "general good or bad" effect of ecotourism on communities based on the allocation of infrastructure showed a difference in opinion among the gender of respondents $\left(\chi^{2}=5.7, p=0.017\right)$.

Figure 7.1 Perceptions of Ecotourism Impacts on the Community and Livelihoods.

(Source: Household Questionnaire)

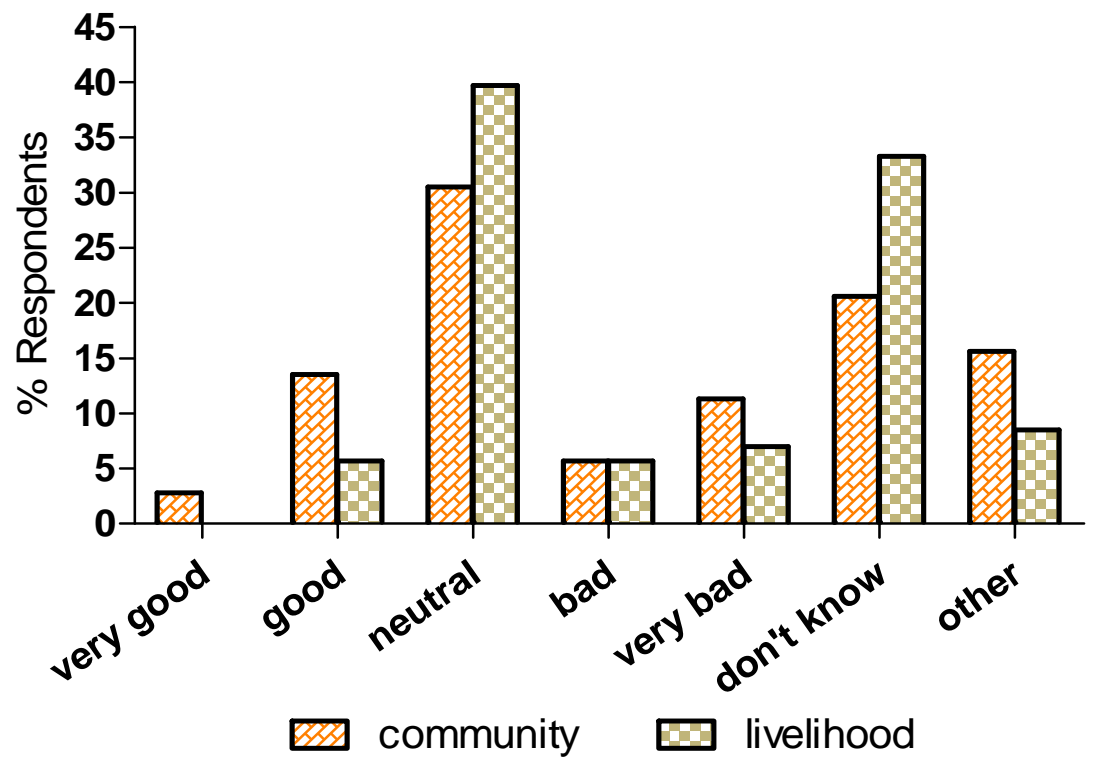

Discussions with community members indicated that, these infrastructures had been provided through non-governmental organizations and the general rural development programme of the central government but had not accrued as benefits through ecotourism. Nevertheless, communities that have not seen such improvement in infrastructure perceived other communities as indirectly benefiting from ecotourism in the form of infrastructure. Respondents justified their ranking of ecotourism mainly based on intended economic benefits and development. The high level of concern expressed in the group discussions regarding the impacts of ecotourism on the community and livelihoods was unmatched in the survey, as only $12.7 \%$ emphatically agreed that it had markedly been bad for their community. However, considering that neutral response can indicate potential negative attitude and perception (Gillingham and Lee, 1999), one has to admit that most of the respondents agreed that ecotourism had at least no advantage for their communities.

The above perception is founded on the fact that there is rather limited evidence of contribution to the local economic situation, improvement in infrastructure or social life from ecotourism (Table 7.4). The communities are basically excluded from any kind of direct benefits. Hence, conservation of the 
Table 7.3 Local Peoples' Attitude Concerning Tourism in Kakum Conservation Area

\begin{tabular}{|c|c|c|c|c|c|c|c|c|c|c|c|c|c|c|}
\hline \multirow{2}{*}{$\begin{array}{l}\text { State- } \\
\text { ment }^{\text {a }}\end{array}$} & \multirow[t]{2}{*}{ Answer } & \multicolumn{3}{|c|}{ Community Cluster $^{b}$} & \multirow[t]{2}{*}{ Total (\%) } & \multicolumn{5}{|c|}{ Variable $^{c}$ in the equation } & \multicolumn{4}{|c|}{ Final logistic model } \\
\hline & & $A$ & $B$ & $\mathrm{C}$ & & & $\mathrm{B}$ & s.e. & Wald & $p$ value & $\operatorname{Exp}(B)$ & $x^{2}$ & $p$ value & $R^{2}$ \\
\hline \multirow[t]{6}{*}{1} & important & 36 & 7 & 16 & $59(41.8 \%)$ & Comty & -2.470 & 0.546 & 20.461 & 0.000 & 0.085 & 30.983 & 0.000 & 0.265 \\
\hline & & & & & & Comty & -1.492 & 0.492 & 9.189 & 0.002 & 0.225 & & & \\
\hline & & & & & & Age & -0.98 & 0.961 & 0.689 & 0.406 & 0.450 & & & \\
\hline & unimportant & 20 & 35 & 27 & $82(58.2 \%)$ & Age & -1.008 & 0.987 & 1.044 & 0.307 & 0.365 & & & \\
\hline & & & & & & educ & -0.850 & 0.467 & 3.313 & 0.069 & 0.428 & & & \\
\hline & & & & & & $\operatorname{sex}$ & -0.364 & 0.395 & 0.852 & 0.356 & 0.695 & & & \\
\hline \multirow[t]{4}{*}{2} & agree & 34 & 12 & 14 & $60(42.6 \%)$ & sex & -0.257 & 0.379 & 0.461 & 0.497 & 0.773 & 23.095 & 0.002 & 0.203 \\
\hline & & & & & & Comty & -1.303 & 0.466 & 7.828 & 0.005 & 0.272 & & & \\
\hline & disagree & 22 & 30 & 29 & $81(57.4 \%)$ & Comty & -1.127 & 0.479 & 5.528 & 0.019 & 0.324 & & & \\
\hline & & & & & & Age & -1.218 & 0.931 & 1.711 & 0.191 & 0.296 & & & \\
\hline
\end{tabular}

${ }^{a}$ statements: 1 = would you say ecotourism is important or unimportant to you?; 2 = tourism activities should be expanded to include tourist visits to the communities

${ }^{b}$ community cluster: $\mathrm{A}=\left(\right.$ Abrafo; Mfuom), $\mathrm{B}=\left(\right.$ Afeaso; Antwikwaa; Bobi), $\mathrm{C}=$ (Mesomagor; Kruwa; Obengkrom). ${ }^{\mathrm{c}}$ variable: sex = gender of respondent, educ = education level, Age $=$ age group of respondent, Comty = community, land = ownership of land 
Table 7.4 Relationship Between Local People and Ecotourism (source: Field Observation and Questionnaires)

\begin{tabular}{ll}
\hline Tourist-Local People Interaction & Situation/Observation \\
\hline Opportunity for interaction & absent - low \\
\hline Income & none \\
\hline Participation in planning & none \\
Attitude to ecotourism impact & variable \\
on community/ PA & \\
Cultural interaction & absent \\
\hline
\end{tabular}

protected area is invariably seen as costs to the local inhabitants who in one way or the other have sacrificed or lost their resource use rights for the 'good of all'. A study by Mehta and Kellert (1998) confirmed that attitudes towards ecotourism corresponded to the economic benefits that local people received from ecotourism.

\subsubsection{Attitudes of Local People and Desirable Future for Ecotourism}

Owing to the abysmal contribution of ecotourism to the development of the adjacent communities and the livelihood of the people, and due to the fact that the majority $(91.5 \%)$ of the household respondents never engaged in livelihood activities related to ecotourism, only $14 \%$ of the respondents approved tourism in the conservation area. Nevertheless, $41.8 \%$ of the respondents agreed to the statement 2: tourism activities should be expanded to include tourist visits to the communities. The logistic regression yielded a significant result $\left(\chi^{2}=23.1, p=0.002\right)$ indicating admittance by the local people that ecotourism could be good for the communities in terms of opening up for development and job opportunities. This underscores the desire of some community members to benefit from ecotourism activities in the conservation area. When asked, $75.2 \%$ of the respondents wanted the youth to have jobs related to conservation activities or the ecotourism programme. This is against the backdrop that there are many out-of-school youth who hang around without gainful employment while others opt to emigrate to bigger towns leaving behind the older folks in the communities.

Subsequently, respondents were asked to identify activities or opportunities for employment and which of these activities they desired to engage as jobs (Figure 7.2). While $35 \%$ identified tour guide as an opportunity, $18 \%$ of the respondents could not point to any activity as job opportunity. When asked which activity they desired, $33 \%$ were open to any opportunity, $21 \%$ desired to be tour guides, while $26 \%$ were not interested in any of the identified opportunities. Few respondents (13.5\%) 
Figure 7.2 Identified and Desired Opportunities/Activities in Ecotourism. (source: Household Questionnaire)

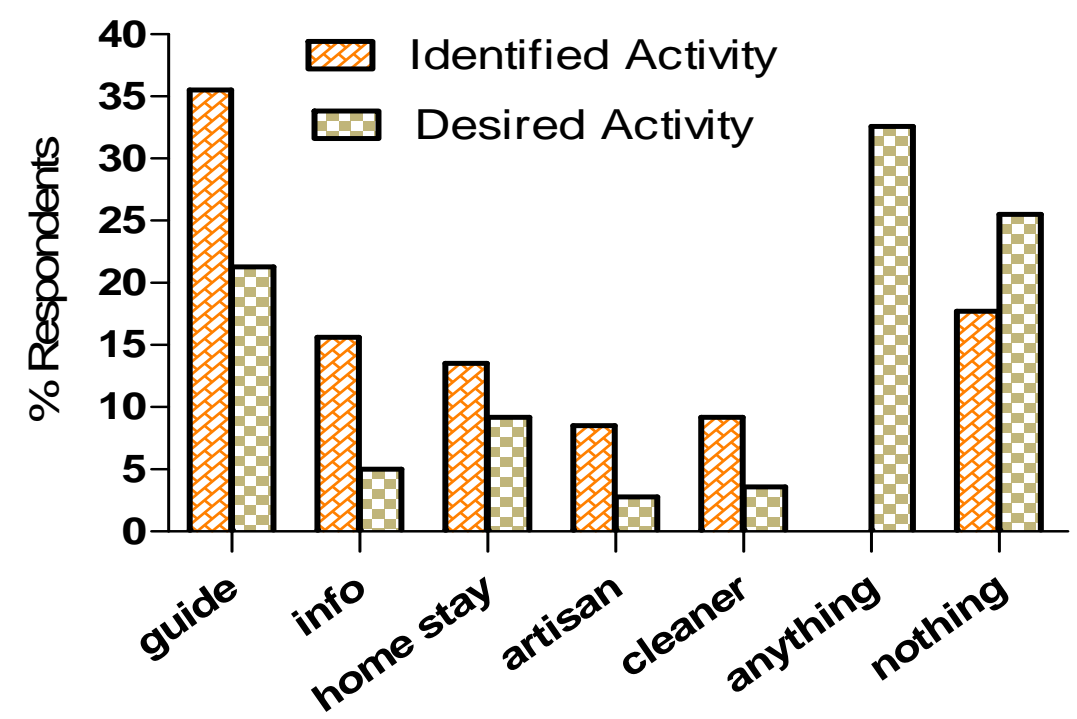

identified home stay (accommodation) as an opportunity to earn money while offering the opportunity to tourists to experience rural life. A smaller number of people were ready to work in the opportunities identified. For example, $21 \%$ of respondents said they would like to work as tour guide, compared to $35 \%$ who identified guiding as an opportunity. Despite the general agitation of none involvement, one quarter of the respondents did not show interest in any of the identified activities. Further, respondents were asked to identify all possible impediments that could hamper taking advantage of job opportunities. Figure 7.3 shows lack of training (19.9\%), family responsibilities (12.8\%) and lack of opportunity (18.4\%) were the most commonly cited impediments, while location/distance (11.3\%) and health/age (10.6\%) were the most important restrictions considering that current tourism activities are concentrated at the south-western part of the conservation area.

Female respondents viewed family responsibilities (24\%), lack of training (17\%) and the location $(13 \%)$ as the most important impediments to engage in tourism related jobs. Their male counterparts also frequently cited lack of opportunity $(27 \%)$, lack of training $(23 \%)$ and health/age $(15 \%)$ as the main impediments to work in tourism related jobs. The interest of respondents to seize job opportunities is evidently low (Figure 7.2) although only 13.5\% indicated lack of interest (Figure 7.3). This attitude is due to the lack of diversification and concentration of ecotourism activities to the south western corner of Kakum National Park. Local people must have to travel long distances from their various communities in order to partake and interact with tourists. 
Figure 7.3 Identified Impediments to Working in Ecotourism.

(source: Household Questionnaire)

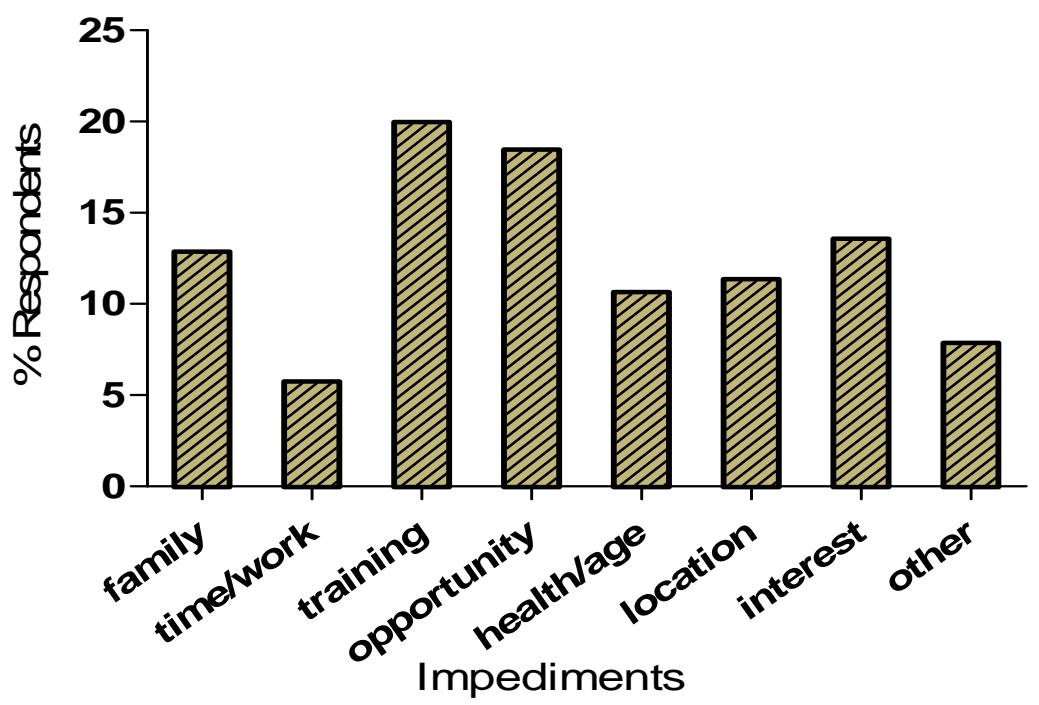

\subsection{Synopsis and Conclusion}

The study examined perceptions and attitudes of local people concerning the Kakum Conservation Area of Ghana. It revealed patterns in local perceptions and attitudes with respect to ecotourism that are of relevance for the debate about ecotourism and protected area management particularly in the KCA of Ghana. The establishment of the protected area and the subsequent promotion of ecotourism as observed by this study, contradict the theoretical idea of ecotourism which seeks to ensure local people's benefits by promoting sustainable local development. Hence, the findings illustrate that local people's perceptions and attitudes are markedly shaped by their perceived losses as well as by their non-involvement in ecotourism management.

The study enumerated some of the main obstacles that prevent local people from participate in ecotourism. In the specific case of KCA, management authorities (WD and GHCT) have neglected to respect and address the needs of local residents, probably as a result of deficiencies in a top-down management strategy. According to Allen, et. al. (1988) governments tend to optimise government economic benefits from ecotourism. Therefore it is necessary to perform a continuous monitoring of its impacts in order to avoid adverse effects and maximise the benefits for local people and development. The study observed a general local support for increasing in tourism activities. Respondents would like to encourage tourist activities to be extended to village communities. This reflects a desire for any form of development rather than the conviction about tourism benefits. The study also noted that most respondents have no clear idea concerning the possible impacts of ecotourism on livelihoods. This is an indication that ecotourism has so far not been beneficial to the 
local people in the Kakum Conservation Area. The local people could be more supportive concerning conservation and accommodative to ecotourism if their needs were adequately addressed.

A dismaying feature of KCA is that, even though tourist visits increased, conservation efforts will continue to face challenges because local people are not adequately involved in planning and management of activities nor do they benefit in any respect. The majority of respondents complained that community interests are not important for the management. Hence there are no viable alternative activities to offset the difficulties resulting from the restrictions imposed on consumptive use of resources in the conservation area. Since there are no direct or quantifiable benefits to the local people, the study could not demonstrate that benefits from ecotourism do engender support for conservation.

Ziffer (1989) stated that ecotourism will not succeed and may even be detrimental to local communities if planning and decision-making does not involve them. Eventually local people would compete with tourists for the resource on which ecotourism depends. Observations indicate that, in spite of all the law enforcement put in by WD staff, there is evidence of permanent unauthorized human activities within the boundaries of the conservation area. To mitigate potential conflicts of interest between park and local people, it is urgent to develop employment opportunities and establish reasonable compensation mechanisms. If ecotourism shall support conservation, it has to support the development around the conservation area. Management authorities should as a matter of urgency address issues of benefit sharing while involving adjacent communities in planning and management. This could be achieved by targeting training programmes to ensure that further development of ecotourism opens up job opportunities for the local people and increase their access to the tourism market. 


\subsection{References}

Allen, L., Long, R., Perdue, R. R. and Kieselbach, S. 1988. The Impact of Tourism Development on Residents' Perceptions of Community Life. Journal of Travel Research 27: 16-21

Andereck, K. and Vogt, C. A. 2000. The relationship between residents' attitudes toward tourism development options. Journal of Travel Research 39: 27-36

Bandara, R. and Tisdell, C. 2003. Comparison of Rural and Urban Attitudes to the Conservation of Asian Elephant in Sri Lanka: Empirical Evidence. Biological Conservation 110 (3): 327-342

Besculides, A., Lee, M. E., and McCormick, P. J. 2002. Residents' perceptions of the cultural benefits of tourism. Annals of Tourism Research 29(2): 303-319

Ghana Statistical Service. 2005. 2000 Population and Housing Census - Analysis of District Data and Implications for Planning, Central Region. Statistical Service, Accra, Ghana

Gillingham, S. and Lee, P. C. 1999. The Impact of Wildlife-Related Benefits on the Conservation Attitude of Local People around the Selous Game Reserve, Tanzania. Environmental Conservation 26(3):218-228

Haralambopoulas, N. and Pizam, A. 1996. Perceived impacts of tourism: The case of Samos. Annals of Tourism Research 23: 503-526

Jim, C. Y. and Xu, S. S. W. 2002. Stifled Stakeholders and Subdued Participation: Interpreting Local Responses towards Shimentai Nature Reserve in South China. Environmental Management 30(3):327-341

King, B., Pizam, A., and Milman, M. 1993. Social impacts of tourism: Host perceptions. Annals of Tourism Research 20: 650-663

Korça, P. 1998. Resident Perceptions of Tourism in a Resort Town. Leisure Sciences 20: 193-212

Kuvan, Y. and Akan, P. 2005. Residents' attitudes towards general and forest-related impacts of tourism: the case of Belek, Antalya. Tourism Management 26: 691 - 706

Landau, S. and Everitt, B. S. 2004. A Handbook of Statistical Analyses using SPSS. Chapman and Hall/CRC

Liu, J. C., and Var, T. 1986. Resident attitudes toward tourism impacts in Hawaii. Annals of Tourism Research 13: 193-214

Mason, P. and Cheyne, J. 2000. Resident attitudes to proposed tourism development. Annals of Tourism Research 27(2): 391-411

Mehta, J. N. and Heinen, J. T. 2001. Does Community-Based Conservation Shape Favourable Attitudes among Locals? An Empirical Study from Nepal. Environmental Management 28 (2): 165-177

Mehta, J. N. and Kellert, S. R. 1998. Local Attitudes toward Community-Based Conservation Policy and programmes in Nepal: A Case Study of the Makalu-Barun Conservation Area. Environmental Conservation 25(4): $320-562$ 
Newmark, W. D., Leonard, N. L., Sariko, H. I., and Gamassa, D. G. M. 1993. Conservation Attitudes of Local People Living Adjacent to Five Protected Areas in Tanzania. Biological Conservation 63(2):177183

Pallant, J. 2005. SPSS Survival Manual. $2^{\text {nd }}$ Edition. A Step by Step Guide to Data Analysis Using SPSS for Windows (Version 12). Open University Press

Ryan, C. and Montgomery, D. 1994. The attitudes of Bakewell residents to tourism and issues in community responsive tourism. Tourism Management 15: 358-369

Snaith, T. and Haley, A. 1999. Residents' opinions of tourism development in the historical city of York, England. Tourism Management 20: 595-603

Teye, M., Sönmez, S. F., and Sirakaya, E. 2002. Residents' attitudes toward tourism development. Annals of Tourism Research 29: 668-688.

Tosun, C. 2002. Challenges of sustainable tourism development in the developing world: The case of Turkey. Tourism Management 22: 289-303

Weaver, D. B. and Lawton, L. J. 2001. Resident perception in the urban-rural fringe. Annals of Tourism Research. 28: 439 - 458

Ziffer, K. 1989. Ecotourism: The Uneasy Alliance. Working Paper Series, Washington, DC: Conservation International 


\section{Chapter Eight: Status of Ecotourism in the Kakum Conservation Area}

\subsection{The Relationship Status of Ecotourism in Kakum Conservation Area}

The study examines perceptions and attitudes of local people around the Kakum conservation area as one of the most significant and most visited protected area of Ghana. The study thus also reveals the concern of residents with conservation and ecotourism management and enriches the debate over the practical achievements of ecotourism and protected areas management. The findings illustrate that local people's perceptions and attitudes are widely influenced by their direct benefits and losses as well as by their involvement in conservation and ecotourism management. Ecotourism by definition is expected to contribute to both biodiversity conservation and local area development. As a basic requirement, mutual endorsement between ecotourism, biodiversity and local people should be facilitated and expedited by appropriate management strategies. The success of biodiversity conservation and ecotourism in protected areas essentially depends on the building of harmonious relationships between the protected areas, its natural resources and local residents, between local people and ecotourism activities, and between ecotourism and the natural environment. The preceding chapters examined various aspects of resource use, local people's involvement in biodiversity conservation and ecotourism, perceptions of costs and benefits of the protected area as well as interactions with visitors or tourists and management staff in the Kakum conservation area. Finally, this section will focus on the direct relationships or interactions illustrated in the conceptual background. For illustration purposes, Figure 3.1 is simplified with colour scheme arrows (Figure 8.1) to highlight the state of the current relationships. By examining the dynamics of these relationships and the role of management, the status (strengths, weaknesses and potentials) of ecotourism at any given site can be revealed. Hence, this section seeks to bring into focus and briefly discuss each of the relationships in turn as observed in the Kakum conservation area.

Figure 8.1 Framework of Current State of Relationships in Kakum Conservation Area

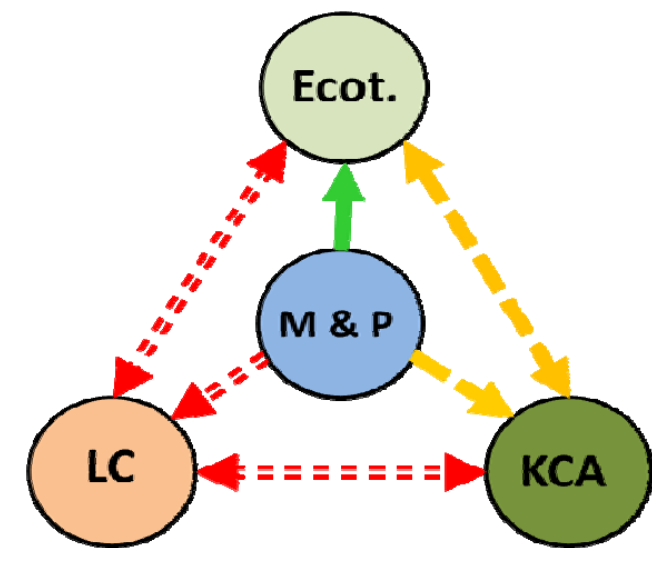

Key:

Ecot. $=$ Ecotourism

$\mathrm{LC}=$ Local Community/People

$\mathrm{KCA}=$ Kakum Conservation Area

M \& P = Management and Policy

$\Longrightarrow=$ Good

$\bigcirc=$ Moderate

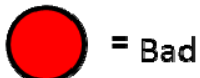




\subsection{Local People and the Kakum Conservation Area}

In a harmonious local people-natural environment relationship, local people are expected to act as stewards of the surrounding natural environment and, in return, they benefit from the natural resources and biodiversity through sustainable harvesting and use of essential resources. The analysis of this relationship in the Kakum Conservation Area and the communities adjacent to it revealed that local people and the protected area are not living in harmony (Figure 8.1). The livelihoods of the populous of communities adjacent to the Kakum conservation area are based on subsistence. They are mainly engaged in food and cash-crop farming with only a few engaged in petty trading (Table 7.2). Legally, they are not allowed to harvest or use resources from the conservation area. Hence, the greatest resource use conflicts involve illegal extraction of resources (including hunting of wildlife and collection of NTFPs). There is also extensive farming around and close to the boundaries of the conservation area, leaving no buffer zone around. Apart from having lost use rights without receiving any compensation for demarcating the area for nature conservation, conflicts between people and the protected area occur in terms of wildlife crop raiding mostly by the forest elephants. Again, no compensation mechanisms to off-set the cash and food crop losses of farmers have even been instituted by management authorities.

Table 8.1 Community Members' Opinions of Ecotourism and Protected Area Management

\begin{tabular}{|c|c|c|c|}
\hline Rank & Factora & Mean & $\% \mathrm{c}$ \\
\hline 1 & Direct involvement of local people will improve conservation of KCA & 4.52 & 93.60 \\
\hline 2 & $\begin{array}{l}\text { Development of multiple ecotourism use sites close to the local } \\
\text { communities will generate more money and incentives for local people }\end{array}$ & 4.45 & 85.80 \\
\hline 3 & $\begin{array}{l}\text { PA and ecotourism linked incentives for communities will reduce } \\
\text { illegal and poaching activities }\end{array}$ & 4.12 & 78.00 \\
\hline 4 & $\begin{array}{l}\text { Identification and development of some NTFPs will increase value for } \\
\text { local people }\end{array}$ & 3.99 & 70.90 \\
\hline 5 & Local residents can better protect the PA from outsiders (poachers) & 3.57 & 63.90 \\
\hline 6 & $\begin{array}{l}\text { Local peoples' involvement in ecotourism management will increase } \\
\text { tourism experience for visitors }\end{array}$ & 2.77 & 43.30 \\
\hline 7 & $\begin{array}{l}\text { Current management arrangements is good enough to protect the PA } \\
\text { over a long period }\end{array}$ & 1.65 & 14.90 \\
\hline
\end{tabular}

Source: Survey data (2009); ${ }^{a}$ Factors are ranked by means of combined values.; ${ }^{b}$ Scale ranges from $1=$ strongly disagree to $5=$ strongly agree; ${ }^{c}$ Percentage agreeing are those answering 4 or 5

The continuous violation of resource use restrictions in the area implies that indeed the local people do not have sustainable alternatives for meeting their everyday livelihood needs and, as a result, oppose and ignore limitations. Although management officials claim they do not have many problems with the immediate surrounding communities with respect to poaching, their none- 
involvement to curb illegal or poaching activities in the area erodes the confidence and trust of the local people in the management strategies. When asked, only $15 \%$ of the household respondents agreed that the current management strategies are appropriate to protect the conservation area over a long period. This means that most of the local people generally do not have confidence in the management strategy. Over $93 \%$ of resident respondents agreed that direct involvement of the local people would improve conservation efforts while $78 \%$ believed that receiving incentives that are linked to the protected area could reduce illegal activities and poaching (Table 8.1). The potential and believe that protected area linked incentives could reduce illegal activities is enforced by over $70 \%$ respondents who agreed that the identification and development of some NTFPs as an option to generate income or goods will increase the value for the local people and consequently will be more committed to protect the resources against outsiders. Continuous pressure on the natural resources through illegal extraction and poaching has the potential to threaten both local people's livelihoods and the overall integrity of the protected area. In order to step up protection of the resources, another $64 \%$ of the respondents agreed that local people had the capacity to support and provide better protection and ward off outsiders or poachers (Table 8.1). However, due to the current abysmal benefits, only $9 \%$ of the respondents would hypothetically agree to enlarge the amount of protected areas (Table 8.2). From the foregoing therefore, it has to be concluded that the ideal symbiotic relationship between people practicing sustainable resource use and the protected area receiving support from resident environmental advocates is not realised in the Kakum Conservation Area. The local people are not benefiting from the protected area and therefore they are also not actively supporting protection and conservation of the resources (Figure 8.1).

\subsection{Ecotourism and Protection of Natural Resources}

In addition to the potential contributions tourism may offer to the well-being of host communities, ecotourism should ultimately contribute to protection and conservation of biodiversity and natural resources. Protected areas should provide tourists with a high-quality experience in nature and, in return, protected areas should receive environmental and economic support. Kakum being a tropical forest has various wildlife species; however, it is difficult to sight these animals on a usual day tour. The canopy walkway on the other hand has served as the major attraction until now. The walk gives a bird's view of the tropical forest and provides unique experience which should be accompanied by opportunities for environmental and conservation education. But unfortunately, apart from an exhibition at the visitor centre, environmental education through skilled guiding, both in the forest and in the exhibition centre, as well as the provision of well-designed information on conservation to 
tourists and local people is limited. The tour guides make efforts to explain the traditional uses and importance of some of the animals and tree species but often the mode of communicating the information lacks the emphasis on conservation.

Although the local people generally do not receive direct benefits from ecotourism and the protected area, $92 \%$ of the respondents agreed that ecotourism should contribute to the conservation of the area (Table 8.2). According to the Wildlife Division officials at the conservation area, revenues (entrance fees, nature walk tour fees and canopy walk fees) generated from tourism in Kakum are shared equally between the Wildlife Division (WD) and the Ghana Heritage Conservation Trust (GHCT). The 50\% share of the WD have to be remitted to a central account of the Forestry Commission, where generally the accumulated funds are redistributed to support the running and maintenance of all protected areas in the country. The GHCT uses part of its share to carry out maintenance of the canopy walkway and infrastructure at the visitor centre. What is guaranteed is some limited amount of fuel, provided by the GHCT, for patrolling the conservation area to enforce use restriction. Beyond this, the site does not receive money specifically earmarked for conservation related research or development from the Forestry Commission. Some $60 \%$ of the local people (Table 8.2) agreed that the economic gains from ecotourism are as important as the protection of the resources however the right balance of financing has not been struck yet.

Table 8.2 Community Residents' Perception of the Environment and Tourism Relationship

\begin{tabular}{|c|c|c|c|}
\hline Rank & Factors $^{a}$ & Mean $^{b}$ & $\%{ }^{c}$ \\
\hline 1 & $\begin{array}{l}\text { Ecotourism in KCA should be integrated with conservation of the PA and } \\
\text { development of the local communities }\end{array}$ & 4.43 & 92.20 \\
\hline 2 & $\begin{array}{l}\text { Ecotourism should be encouraged in other parts of the PA provided they } \\
\text { do not conflict with the conservation objectives }\end{array}$ & 4.37 & 88.70 \\
\hline 3 & The PA together with the wildlife needs greater protection & 3.79 & 70.90 \\
\hline 4 & Increased ecotourism will not harm the PA & 3.65 & 68.80 \\
\hline 5 & $\begin{array}{l}\text { The economic gains of ecotourism are as important as the protection of } \\
\text { the PA }\end{array}$ & 3.50 & 59.60 \\
\hline 6 & $\begin{array}{l}\text { There should be more PA established in the Central Region for } \\
\text { biodiversity conservation and ecotourism development }\end{array}$ & 1.39 & 9.20 \\
\hline
\end{tabular}

Source: Survey data (2009); ${ }^{a}$ Factors are ranked by means of combined values.; ${ }^{b}$ Scale ranges from $1=$ strongly disagree to $5=$ strongly agree; ${ }^{c}$ Percentage agreeing are those answering 4 or 5

Education in the form of active interpretation programmes (such as guided tours or group activities, and school/community outreach) in protected areas and passive interpretation (in the form of reading materials, maps, signs, information centres) could serve three essential purposes: 
i) to direct the tourists or visitors in behaving in an environmentally sensitive manner while enjoying the natural experience;

ii) to enhance appreciation for the natural surroundings by providing opportunities to learn about natural features (flora and fauna);

iii) to promote a conservation ethic and environmental stewardship both for tourists or visitors and for local communities adjacent to the conservation area.

The above points are actually tenets of ecotourism management but presently, the tourism practice and management in Kakum is falling short in all the three objectives.

Given the limited funding available for park management, active conservation education is also inadequate in all the adjacent communities. Although infrastructure to support some level of conservation education does exist at the visitor centre, the requisite skills to facilitate the educational objectives of the protected area are lacking and this compromises both the nature experience of tourists and the contributions ecotourism can make to conservation. Again, there is limited availability of printed materials on species of conservation interest and their importance. This also reduces the potential for conservation education and learning. Given the inherent knowledgeseeking motivations of the typical ecotourists, the quality of their nature experience suffers to some extent when opportunities to learn about the forest tree species they are viewing or the birds they are hearing and seeing as well as about all other species are not available in the form of simplified species check books or manuals and pamphlets. It is believed that ecotourists who enjoy a highquality experience in nature might be more willing to pay substantial fees to increase revenue, particularly if the fees are to be used to maintain the protected area directly. From the foregoing, it can be concluded that the ecotourism-protected area relationship currently exists only at a moderate level (Figure 8.1).

\subsection{Ecotourism and Local Communities}

Apart from the generation of foreign exchange for the country, ecotourism development is expected to contribute to communities locally by providing opportunities and means for economic and social benefits, infrastructural improvements, and an additional rationale or justification for biodiversity conservation both within and outside protected areas. Tourists patronising these areas in return, can have their experiences enhanced through the provision of opportunities to interact with local people and experience life in different cultural settings. Through these interactions, inter-cultural appreciation and understanding between tourists and local people can be facilitated. Such an 
interaction could instil a sense of pride in the local people and facilitate the promotion of their cultural heritage. Unfortunately this tourist-local people interaction is very limited or none-existent for most communities in the Kakum conservation area. So far, ecotourism in Kakum does not achieve the purpose of enhancing inter-cultural appreciation and exchange between local people and tourists, thus this relationship almost non-existent or bad (Figure 8.1). Local pride in culture is a manifestation of cultural self-confidence and awareness. Where there is high sense of pride, local knowledge also stays within the community and is passed on to the following generation.

Tourism activity in Kakum is limited to a small portion of the protected area. This makes it difficult to provide communities with the means and access to participate in and adapt to the introduction and management of tourism. So far, tourism has provided no opportunities for positive tourist-local people interactions and therefore its economic and socio-cultural impacts are also not being experienced by the local people (Figure 7.1). To achieve positive impacts and benefits from tourism, the local people would like to participate in the provision of labour and services (Figure 7.2). But in the current state, respective opportunities could only be generated or realised if more tourism activity sites are developed close to the local communities. Eighty six percent of the respondents expressed their strong expectation that development of multiple ecotourism sites close to the local communities would generate incentives for the local people (Table 8.1) and thereby enhance a positive ecotourism-local community interaction. Another, $89 \%$ of the respondents (Table 8.2 ) also advocated that ecotourism should be encouraged in other parts of the protected area provided that it does not conflict with the objectives of conservation.

When local communities do not receive substantial benefits from ecotourism but have to recognise that most benefits are being accrued by outsiders, while the community has to face resource restrictions as a result (i.e. cost) of conservation, their attitudes towards conservation are likely to be negative. Thus, tourism in Kakum has not encouraged positive attitudes towards conservation nor did it result in positive cultural interactions. With the exception of a very small number of local people who sell local goods (fruits and handicrafts) at the protected area's main entrance, waitress at the restaurant or perform at the visitor centre, the majority of local residents have nothing to do with ecotourism in the Kakum Conservation Area. In order to foster positive links with conservation initiatives, local residents must be able to feel a sense of control in running relevant local businesses and ownership over planning and processes involving resource uses in the conservation area. 


\subsection{Management Role of Authorities}

At present, the immediate authorities responsible for managing the interactions described in the evaluative framework (Figure 3.1) are the Wildlife Division and the GHCT. The role of GHCT was to facilitate the socio-economic development of the local community, maintenance of the tourism facilities and support nature conservation activities. So far, their role has been limited to the maintenance of the on-site tourism infrastructure (section 8.1.2). During the interviews, the Director intimated that the GHCT had put forward a benefit sharing formula for consideration by the central government. If the formula gets approval, local communities would be receiving benefits as a result of the revenues generated from ecotourism activities in the conservation area. The arrangement is similar to the royalty payment system instituted for traditional areas whose lands are used for timber extraction or precious mineral extraction. The benefits are paid to the chiefs of the communities to support development programmes at the community level. However, the concern is that, neither the GHCT nor the government has the immediate control on how these funds would eventually be used in the communities, and therefore they have also advocated for mechanisms of accountability in how the funds are utilised so that all sections of the community members would benefit.

The Wildlife Division on the other hand is also increasing efforts in preventing consumptive use and managing visitor activities to avert negative impacts on the conservation area. Although the management has not risen above the challenges, there are signs of limited interaction with local communities. Monitoring or protection activities (section 4.4.1) have been stepped up but this has not been accompanied by adequate outreach programmes with the surrounding communities, hence the persistence of illegal activities. In sum, there is no current programme to actively involve the local people, aside keeping them out of the protected area, thus resulting in a very weak or non-existent relationship with the management authorities (Figure 8.1). Beyond this challenge, the officials have managed to deliver creditably to the satisfaction of the tourists which was evident in the surveys, indicating a good management-tourists relationship. That notwithstanding, the tourist expressed their desire for additional recreational options, which when given the necessary consideration could increase the Kakum experience. 


\section{Chapter Nine: Assessment and Recommendations for Future Strategic Management Planning in Kakum Conservation Area}

\subsection{Methodological Background}

Strategic management, according to Yüksel and Dağdeviren (2007) can be understood as the set of decisions and actions taken to determine the long-term activities of an organization. There are many approaches and techniques that can be used to prepare for strategic management processes from which the Analytic Hierarchy Process (AHP) has been adapted has been widely used as a method in forestry and forest management planning. A compendium of its general applications in scenarios of forest and natural resources management in published literature has been provided by Schmoldt, et. at. (2001).

\subsubsection{The Analytic Hierarchy Process (AHP)}

Analytic Hierarchy Process is a comprehensive framework which is designed to cope with the intuitive, the rational, and the irrational when multi-objective, multi-criterion, and multi-actor decisions are to be made, with or without certainty, for any number of alternatives. Its basic assumption is the functional independence of the groups (objective and criteria) in the hierarchy, and of items in each level of the criteria and alternatives (Lee and Kim, 2000). It piggybacks on a precursory SWOT-analysis and its subsequent derivation of alternative strategic options by using the TOWS-matrix. It provides well structured, systematic decision making analysis and support, incorporating both qualitative and quantitative attributes. In this respect it can be considered as a general theory of measurement based on mathematical and psychological foundations (Kurttila, et. al., 2000), and a mathematical method for analysing complex problems with multiple criteria. AHP was originally developed by Saaty $(1977 ; 1980)$. Due to its usefulness in decision-analysis, the technique has been applied in cases dealing with strategic planning, including marketing applications (Wind and Saaty, 1980), as well as in the design and evaluation of business and corporate strategy (Wind, 1987).

\subsubsection{SWOT-Analysis}

SWOT stands for Strengths, Weaknesses, Opportunities and Threats. SWOT analysis is an important brain-storming tool for decision-making, which is used to analyse an organisation's internal and external environment (Kangas, et. al., 2003; Kurttila, et. al., 2000). According to Helms and Nixon (2010), SWOT analysis was described by Learned et. al. (1969) and has since then grown to be one of the key tools for addressing complex strategic situations by reducing the quantity of information to 
improve decision-making. SWOT analysis is a simple yet useful planning tool to understand the 'Strengths', 'Weaknesses', 'Opportunities' and 'Threats' as part of a strategic planning process. It is often employed when monitoring or evaluating a specific programme, service, product or industry and exploring measures for improvement (Harrison, 2002). Kotler (1994) explained that during the planning process various factors influencing the operational environment are diagnosed in details.

Furthermore, Helms and Nixon (2010) noted that there is an agreement in the strategic management arena to the fact that SWOT analysis provides the foundation for the realisation of the desired alignment of organisational variables or issues. They stated that by listing favourable and unfavourable internal and external issues, planners can better understand how strengths can be leveraged to realise new opportunities and understand how weaknesses, if not well managed, can also slow the progress or magnify organisational threats. In principle, SWOT analysis facilitates the understanding of the issues with regards to their causal effects on the operations of the organisation or institution. Hence, it is useful to be applied when preparing for future scenarios.

The advantages of SWOT analysis are that it is simple and cost efficient. SWOT could generate many ideas which could be useful in outlining key management issues. SWOT analysis has been employed in several situations. Wrigley and Gould (2002), for example used SWOT to assess the need for recreation and ways to increase user participation in public park environment (Pukekura Park) in New Zealand, while the tool has also been used to recommend tourism development plans in Portugal (Ramos, et. al., 2000).

Hence, this section is dedicated specifically to the identification of the strengths, weaknesses, opportunities and threats concerning biodiversity conservation and ecotourism management in the Kakum Conservation Area (KCA). There has not been any notable SWOT analysis conducted for the conservation area so far, although there are many opportunities for KCA to grow as an important ecotourism destination in Ghana for both local people and foreign visitors.

SWOT analysis however lacks the capacity to comprehensively appraise the possible strategic decision-making situation; merely outlining factors in the strength, weakness, opportunity or threat matrix does not necessarily pinpoint the most significant issue. In this regard, it should be noted that SWOT does not include any means to analytically determine the importance of the factors or of assessing the fit between the SWOT factors and the decision alternatives. Therefore, SWOT is mainly based on qualitative analysis. For the purpose of facilitating and improving strategies for the 
management of KCA, and in taking cognisance of the limitations of SWOT, the analysis attempts to go beyond just listing the SWOT factors by performing situational analysis, thus analysing the Threats (T) and Opportunities $(\mathrm{O})$ in the external environment, and assessing the Weakness (W) and Strengths (S), conveniently called the TOWS matrix technique (Wiehrich, 1982). The Analytic Hierarchy Process (AHP) is also utilised to prioritise the factors of proposed strategic options, in the TOWS technique, for the consideration of the management authorities in KCA and possibly kick-start efforts to implement some of the proposed strategies.

\subsubsection{The TOWS Matrix}

According to Weihrich (1982), it is common to suggest that companies or institutions identify their strengths and weaknesses, and the opportunities and threats in their environment. However, what is often overlooked is that combining these factors may require distinct strategic choices. The TOWS matrix was therefore proposed to help in systematically identifying the relationships between the threats, opportunities, weaknesses and strengths, and then offers a structure for generating strategies on the basis of these relationships (Weihrich, 1982). In simple terms, it is a framework that facilitates the matching of external threats and opportunities with the internal weaknesses and strengths of an organisation with respect to their operations.

The TOWS Matrix indicates four conceptually distinct alternative strategies and actions which may overlap and therefore be implemented concurrently. Below are brief explanations of the aims of each group of the alternative strategies:

i. The $\mathbf{W}-\mathbf{T}$ Strategy: The aim of the $\mathrm{W}-\mathrm{T}$ strategy is to generally minimise weaknesses in the institution in order to avoid the external threats relevant to the institution's operations or existence. An institution may be in a difficult situation when it is faced with external threats which could affect its operation as a result of the internal weaknesses. Weihrich (1982) noted that in such a situation, the institution, among other options, may want to cut back on its operations or merge some programmes with another institution to leverage resources in a better way. This includes the intent of overcoming the weaknesses, but is rather defensive, which is why whatever strategy is selected, the W-T position is one that any institution will try to avoid. 
ii. The W-O Strategy: The second strategy attempts to minimise the weaknesses in order to take advantage of existing opportunities. Institutions may identify opportunities in their external environment but may have organisational weaknesses which may prevent them from taking advantage. In such situation, the institution could hire a consultant or outsource the intended project/programme. Alternatively, a staff member could be trained to become an in-house expert on the issue.

iii. The S-T Strategy: This strategy is based on the strengths of the institution that can deal with threats in the environment. The aim is to maximise the former in order to fight against the latter. Thus, using the strengths to mitigate the threats. Suppose there is a threat of dramatic reduction in funding for nature conservation programmes; if an agency is efficient than other agencies in its field of operation as nature conservation agency, utilising volunteers can serve as a strategic advantage to become even more efficient and effective to overcome the drastic reduction in availability of funding.

iv. The S-O Strategy: Any institution or agency would like to be in a position where it can use its strengths to benefit from existing opportunities. Successful institutions, even if they temporarily use one of the three previously mentioned strategies, will attempt to get into such a situation (Weihrich, 1982). Thus if they have weaknesses, they will strive to overcome them, making them strengths. If they face threats, they will cope with them so that they can focus on opportunities.

The further analysis follows steps $2-4$ described below. Also, the description highlights the most important aspect of the AHP concept. For more details on the AHP theory, refer to Saaty (1977, 1980). The AHP analytical method proceeds as follows:

Step 1. Perform SWOT analysis: Identify the relevant factors of the external and internal environment in a SWOT analysis matrix and proceed to produce the TOWS matrix by identifying strategic options that can tackle the main concerns or objectives. It is recommended that when standard AHP is applied, the number of factors within a SWOT group should not exceed 10 because the number of pairwise comparisons needed in the analysis increases rapidly (Saaty, 1980). In this analysis however, the AHP is applied to the TOWS factors or strategies. 
Step 2. Pairwise comparisons between TOWS factors are carried out within every TOWS group: In making the comparisons, the questions to ask are: 1. which of the two factors or strategies compared has a greater potential to achieve the objective; and 2. how much greater is this potential, using the 1 - 9 scale provided by Saaty (1990) presented in Table 9.1. With these comparisons as the input, the relative local priorities of the factors or strategies are computed using the eigenvalue method. These priorities reflect the decision maker's perception of the relative importance of the factors.

Table 9.1 Saaty's 1 - 9 Fundamental Scale for AHP Preference (Saaty, 1990)

\begin{tabular}{|c|c|c|}
\hline $\begin{array}{l}\text { Intensity of } \\
\text { importance }\end{array}$ & Definition & Explanation \\
\hline 1 & Equal importance & Two activities contribute equally to the objective \\
\hline 3 & $\begin{array}{l}\text { Moderate importance of one over } \\
\text { another }\end{array}$ & $\begin{array}{l}\text { Experience and judgement slightly favour one over } \\
\text { another }\end{array}$ \\
\hline 5 & Strong importance & $\begin{array}{l}\text { Experience and judgement strongly favour one over } \\
\text { another }\end{array}$ \\
\hline 7 & Very strong importance & $\begin{array}{l}\text { Activity is strongly favoured and its dominance } \\
\text { demonstrated in practice }\end{array}$ \\
\hline 9 & Extreme or absolute importance & $\begin{array}{l}\text { The evidence favouring one activity over another is of } \\
\text { the highest possible order of affirmation }\end{array}$ \\
\hline $2,4,6,8$ & Intermediate values & $\begin{array}{l}\text { Used to represent compromise between priorities listed } \\
\text { above }\end{array}$ \\
\hline $\begin{array}{l}\text { Reciprocals } \\
\text { of above } \\
\text { non-zero } \\
\text { number }\end{array}$ & \multicolumn{2}{|c|}{$\begin{array}{l}\text { If activity } i \text { has one of the above non-zero numbers assigned to it when compared with activity } j \text {, } \\
\text { then } j \text { has the reciprocal value when compared with } i\end{array}$} \\
\hline
\end{tabular}

Step 3. Pairwise comparisons are made between the four TOWS groups: At this stage, the factor or strategy with the highest local priority is chosen from each group to represent the group. These four factors are then compared and their relative priorities are calculated as in Step 2. These become the scaling factors of the four TOWS groups and they are used to calculate the overall global priorities of the independent factors or strategies within them. This is done by multiplying the strategies' local priorities as defined in Step 2 by the value of the corresponding scaling factor of the TOWS group. The global priorities of all the factors or strategies sum up to one. The eigenvectors were computed by analysing the matrices using an AHP Excel Template provided by Goepel $(2013)^{10}$. The details of the pairwise comparison matrices are provided in Appendix Six.

Step 4. The results are utilized to priorities the strategy formulation and the implementation processes:

The contribution to the strategic planning process comes in the form of numerical values for the factors. Following the derived priorities, new goals may be set with respect to the defined strategies and subsequently, plans for implementations can take into consideration the foremost factors.

\footnotetext{
${ }^{10}$ Goepel, K. D., BPMSG AHP Excel template with multiple inputs, version 08.05.13 - http://bpmsg.com, Singapore 2013
} 


\subsection{Assessment Process}

The SWOT analysis and the subsequent utilisation of the TOWS matrix and AHP is aimed at choosing appropriate management strategies for the KCA, based on the identified strengths, weaknesses, opportunities and threats, and following the specific objectives outlined by the Ghana Wildlife Division as their management guidelines for the Kakum Conservation Area (see section 4.3):

i. To actively protect and conserve all natural resources and aesthetic features;

ii. To integrate the conservation area into the district and regional development process, especially into that of the surrounding communities, to ensure their cooperation and support for the conservation of the resources;

iii. To exploit the tourism potential and sustainably develop it based on the recreational, educational and aesthetic appeal (Wildlife Department, 1996).

Basically, these objectives culminate to sustainable non-consumptive use through protection and ecotourism development that is beneficial to the local people in the surrounding communities. The effective execution of these objectives is therefore necessary to achieve the tenets of ecotourism as well as to ensure the active participation of the local people in the protection of the area. The following subsections have outlined and attempted to explain the TOWS and AHP employed, and the steps involved in arriving at the prioritisation of the strategic options.

The SWOT factors in Tables 9.2 and 9.3, from which Table 9.4 was derived, were obtained from the empirical data (visitor and community surveys, group discussions, interviews and observations) collected during the field visits. Additionally some of the factors were obtained through secondary sources including official documents and reports on protected areas management in Ghana. These SWOT factors listed are not exhaustive. However, since there are too many possible factors that can be analysed, the analysis was selective and concentrated on those factors that are critical for achieving the above listed objectives of the Wildlife Division.

\subsection{Results and Discussion}

Upon synthesising and analysing all the relevant data gathered they were organised into four groups in accordance to the SWOT and TOWS matrices (Tables 9.2; 9.3 and 9.4). This section will discuss a few of the critical factors that have been selected under each of the SWOT groups in Table 9.4. 


\subsubsection{The SWOT}

The Strengths: For a protected area and a tourism destination, some notable strengths includes the clear demarcation of boundaries, and the legal protection through the Wildlife Reserves Regulations (LI 1525), (see section 4.2.1). The high biodiversity and numerous species of conservation interest, and being gazetted give an important legal barking for the Wildlife Division to enforce protection regulations. Also, since the conservation area is gazetted for protection of biodiversity, no major construction or alteration of the ecosystem, or extraction of resources, which otherwise could be detrimental to the ecosystem and the wildlife therein is allowed. The enforcement of protection regulations through foot patrols by Wildlife guards, on the other hand, deters people from undertaking massive extraction of resources. This means that the forest structure can be maintained to ensure enrichment in the floral composition and maintenance of microclimate to support wildlife species. Being a remnant of the Upper Guinea forest ecosystem, the conservation area presents itself as a special ecosystem, with unique attraction for tourism activities. With vast butterflies and bird species, it is a good place for bird watchers and butterfly lovers. The proximity of the conservation area to other monumental attractions also facilitates its high patronage.

Table 9.2 A SWOT Analysis of Biodiversity Protection in the Kakum Conservation Area

\begin{tabular}{|c|c|c|}
\hline & Positive & Negative \\
\hline & $\begin{array}{l}\text { Strengths } \\
\text { 1. Area is gazetted } \\
\text { 2. High diversity and species of conservation interest } \\
\text { 3. No permanent settlements within the boundaries } \\
\text { 4. Acceptance of the importance of the conservation } \\
\text { area by local people } \\
\text { 5. Enforcement of protection regulations } \\
\text { 6. Logistical /financial support from NGOs } \\
\text { 7. Well demarked and undisputed boundaries } \\
\text { 8. Numerous river bodies within PA support the wildlife }\end{array}$ & $\begin{array}{l}\text { Weaknesses } \\
\text { 1. Lack of formal and active involvement of local } \\
\text { communities (people) in management } \\
\text { 2. Limited personnel (quantity and quality of } \\
\text { expertise) } \\
\text { 3. Insufficient financial means to support research } \\
\text { 4. Poor data collection, storage and processing of } \\
\text { patrol records and animal sighting } \\
\text { 5. No designated buffer zone } \\
\text { 6. Deficiency in law enforcement } \\
\text { 7. Limited outreach and conservation education } \\
\text { programmes } \\
\text { 8. Failure of alternative livelihood improvement } \\
\text { projects }\end{array}$ \\
\hline & $\begin{array}{l}\text { Opportunities } \\
\text { 1. Support of international institutions (IUCN, Cl, etc) } \\
\text { 2. Political stability of the country } \\
\text { 3. Local people's interest to participate in management } \\
\text { 4. Local people's interest to participate in alternative } \\
\text { livelihood activities } \\
\text { 5. Implementation of alternative livelihood/income } \\
\text { generation projects } \\
\text { 6. Support of traditional authorities } \\
\text { 7. Introduction of environmental education in local } \\
\text { Schools }\end{array}$ & $\begin{array}{l}\text { Threats } \\
\text { 1. Dependency of local people on forest resources } \\
\text { 2. Wildlife-human conflicts (crop raiding) } \\
\text { 3. Presence of illegal users (poaching) } \\
\text { 5. Expansion of agricultural activities close to } \\
\text { boundaries } \\
\text { 6. Communities located close to boundaries } \\
\text { 7. No payment of compensation for wildlife crop } \\
\text { damage } \\
\text { 8. Ecological isolation } \\
\text { 9. Threat of reduction in genetic and species } \\
\text { diversity due to ecological isolation }\end{array}$ \\
\hline
\end{tabular}


The Weaknesses: However, the analysis also identified several internal weaknesses, both with regards to nature protection and tourism management (Tables 9.2 and 9.3). Clearly, there is a deficiency in law enforcement as a result of inadequate number of patrol staff. A critical weakness is the poor data collection and management. This weakness is critical because it does not allow the management authorities to have accurate knowledge about the wildlife species, their individual population, distribution and comprehensive habitat requirements in order to ensure full protection. Additionally, the poor data collection does not allow for proper monitoring of the resident wildlife species.

Table 9.3 A SWOT Analysis of Tourism Management in the Kakum Conservation Area

\begin{tabular}{|c|c|c|}
\hline & Positive & Negative \\
\hline & $\begin{array}{l}\text { Strengths } \\
\text { 1. Unique attraction (Canopy walkway and tropical } \\
\text { biodiversity) } \\
\text { 2. Proximity to other significant tourism sites } \\
\text { 3. Existence of a visitor/information (exhibition) } \\
\text { facility } \\
\text { 4. Relative good accessibility to the main activity } \\
\text { Centre } \\
\text { 5. Well publicised tourist attraction } \\
\text { 6. High visitor satisfaction } \\
\text { 7. Well patronised tourist attraction } \\
\text { 8. Higher proportion of local (Ghanaian) visitors } \\
\text { 9. Multi-tiered entrance fee system } \\
\text { 10. Acknowledgement of value for money } \\
\text { 11. Interpretive activity by guides during the tours }\end{array}$ & $\begin{array}{l}\text { Weaknesses } \\
\text { 1. Lack of specific ecotourism development and } \\
\text { management strategy/plan } \\
\text { 2. No involvement of local people } \\
\text { 3. Low return rate of tourists } \\
\text { 4. Short duration of stay } \\
\text { 5. Elusive wildlife species } \\
\text { 6. Poor road access and infrastructure in most } \\
\text { neighbouring communities } \\
\text { 7. Lack of specific budgetary allocation for research } \\
\text { and conservation } \\
\text { 8. Minimal diversity of tourism activities available }\end{array}$ \\
\hline & $\begin{array}{l}\text { Opportunities } \\
\text { 1. Willingness of local people to participate in } \\
\text { tourism development and management } \\
\text { 2. Growth of interest in ecotourism } \\
\text { 3. Existence of several tourist attractions in the } \\
\text { region } \\
\text { 4. Development of handicraft centre } \\
\text { 5. Rural activities and farm visits as potential } \\
\text { tourism attraction } \\
\text { 6. Organised tours by travel agencies } \\
\text { 7. Tourists' request of additional recreational } \\
\text { options } \\
\text { 8. Employment for local people } \\
\text { 9. Willingness of visitors to recommend site } \\
\text { 10. High local and regional ecotourism potential } \\
\text { 11. Establish cooperatives to govern alternative } \\
\text { livelihood improvement schemes }\end{array}$ & $\begin{array}{l}\text { Threats } \\
\text { 1. Poverty or low purchasing power of local people } \\
\text { 2. Infrastructure development } \\
\text { 3. Local people's adoption of exotic lifestyle (change } \\
\text { in attitudes and behaviour) } \\
\text { 4. Lack of resources and capacity for local people to } \\
\text { invest in tourism operations } \\
\text { 5. Lack of economic benefit for local communities } \\
\text { 6. Mediocre management of tourism } \\
\text { 7. Lack of infrastructure (health, education, and } \\
\text { market/trading facilities) } \\
\text { 8. Limited working and education opportunities in } \\
\text { the area } \\
\text { 9. Inadequate information on site available to } \\
\text { tourists }\end{array}$ \\
\hline
\end{tabular}

Although every effort is being made to enforce protection regulations, the limited number of personnel renders the patrol efforts inadequate to completely curtail illegal activities within the protected area. The control and eradication of illegal activities could be better handled with the active involvement of the resident local people. Also, the failure and discontinuation of alternative 
livelihood projects in the neighbouring communities has taken away the incentive for conservation. Hence there is not enough motivation for some of the local people to participate in conservation initiatives that could facilitate enforcement of use restrictions among members of neighbouring communities or to guard the forest and wildlife resource from people infiltrating the conservation area from distant communities. Another notable weakness is the lack of specific ecotourism development and management strategy/plan. The absence of specific strategic development plan for any programme sometimes results in taking ad hoc decisions which may end up to waste limited resources and reduce the potential to maximise overall outcomes. The non-existent of a strategy could also be a reason for the minimal involvement of the local people, who ideally should be benefiting from the ecotourism activities within the conservation area.

The Opportunities: In spite of all the weaknesses listed with respect to ecotourism management and biodiversity conservation in Kakum (Tables 9.2 and 9.3), there are many opportunities that could be capitalised on to improve biodiversity conservation and ecotourism management. Within the framework of the SWOT analysis, if the present opportunities are well identified and the right strategies are adopted for successful utilisation of those opportunities, they could become future strengths. Thus, the aim of the administrative authorities should be focused on exploiting any opportunity identified.

The management authorities can capitalise on local people's interest to participate in conservation and actively engage them. Likewise, considering that tourists have requested for additional recreational options, the authorities and tour operators can take advantage to plan for additional trips to involve farm visits and participation in activities performed in the local communities. Operationalizing these opportunities could be an avenue for generating sustainable income for the local communities, and thereby involving them in the planning and management of ecotourism in the area. Beside the economic benefits, utilising these opportunities can help increase conservation awareness and appreciation of local livelihoods and culture.

The Threats: Aside the opportunities in the external environment, there are several threats with varying degrees of importance that could affect conservation efforts or improvement in ecotourism within the Kakum Conservation Area (KCA). As indicated earlier, poaching is a major threat to conservation of forest and wildlife species. There is evidence that the incidences of poaching are still high in KCA (see section 4.4.1). The expansion of agricultural activities close to the protected area boundaries is increasingly isolating the protected zone, converting it into an ecological island. Such 
development can be problematic for wildlife species that require vast habitat ranges. On the other hand, since the protected area is completely surrounded by food and cash crop farms, when wildlife species stray or move across the boundary line, they end up in cultivated farms and cause damage to the food and cash crops. This can further escalate the human-wildlife conflicts within the area (see Monney, et. al., 2010; Lamarque, et. al., 2009). Wildlife raiding farms result in economic losses and therefore a disincentive for the local people facing such challenges. This can trigger negative attitudes towards wildlife and forest conservation. Furthermore, local people's continual dependence on forest and wildlife resources for their livelihood poses threat to conservation. Particularly where there are no provisions for alternative sources, people will poach to satisfy their livelihood and resource needs, which could eventually affect conservation objective negatively depending on the status of the target species and the scale of the poaching.

\subsubsection{The Possible TOWS Strategies}

The $\mathbf{W}$-T Strategy: The ideal is to attempt to overcome weaknesses and develop them into strengths in order to counteract external threats more efficiently. In other words, move towards the S-O position in the matrix as shown Table 9.4. Since consolidation needs time, other more immediate measure have to be taken in order to avoid damages and losses. Specifically, the threat posed by lack of economic benefits for the local people can be mitigated by implementing alternative income and livelihood support programmes in the communities. This strategy would require huge financial input. However, the success of such programmes can avert illegal activities. Additionally, considering the high incidences of illegal activities within the conservation area, the Wildlife Division can consider the option of involving some of the local people in joint patrol activities. Such an arrangement can increase the frequency of patrolling and consequently the rate of preventing illegal activities.

Furthermore, since agricultural activities close to the protected area boundaries have the potential to increase human-wildlife conflicts, the management authorities can discuss with the traditional authorities and the local people to establish a minimum farming distance away from the boundaries. The created zone can then be used to experiment strategies to prevent wildlife from raiding food and cash crops. The success of such a strategy could also reduce the sharp gradient from high forest to cultivated farms just at the boundaries. Depending on how wide the minimum distance to be agreed upon, this could serve as a buffer zone for the regeneration of essential forest resources to be harvested by the land owners. However, the administrative authorities should note that this strategy can be met with scepticism and possible non-cooperation. Therefore implementing this strategy 
Table 9.4 Combined SWOT Analysis and TOWS Strategies Concerning Biodiversity Conservation and Tourism Management in Kakum

\begin{tabular}{|c|c|c|c|}
\hline & & \multicolumn{2}{|c|}{ INTERNAL } \\
\hline & & $\begin{array}{l}\text { Strengths } \\
\text { 1. Unique attraction within the sub-region } \\
\text { 2. Species of conservation interest } \\
\text { 3. Acceptance of the importance by local communities } \\
\text { 3. No permanent settlements within boundaries } \\
\text { 4. Enforcement of protection regulations } \\
\text { 5. Proximity to other tourist attractions } \\
\text { 6. High visitor satisfaction } \\
\text { 7. Well publicised tourist attraction }\end{array}$ & $\begin{array}{l}\text { Weakness } \\
\text { 1. Lack of formal and active involvement of local } \\
\text { communities (people) in management } \\
\text { 2. Poor data collection, storage and processing of } \\
\text { patrol records and animal sighting } \\
\text { 3. Deficiency in law enforcement } \\
\text { 4. Failure of alternative livelihood improvement } \\
\text { Projects } \\
\text { 5. Lack of specific ecotourism development and } \\
\text { management strategy/plan } \\
\text { 6. Minimal diversity of tourism activities available }\end{array}$ \\
\hline \multirow[b]{2}{*}{ 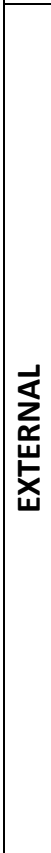 } & $\begin{array}{l}\text { Opportunities } \\
\text { 1. Local people's interest to participate in } \\
\text { conservation management } \\
\text { 2. Support of traditional authorities } \\
\text { 3. Willingness of local people to participate in } \\
\text { tourism development } \\
\text { 4. Rural activities and farm visits as potential } \\
\text { tourism attraction } \\
\text { 5. Request for additional recreation Options } \\
\text { 6. Organised tours by travel agencies }\end{array}$ & $\begin{array}{l}\text { S-O Strategies } \\
\text { SO1. Form partnership for package tour between local } \\
\text { communities, KCA management and tour } \\
\text { operators } \\
\text { SO2. Form partnerships with universities to attract } \\
\text { researchers and volunteers to monitor } \\
\text { biodiversity with local people } \\
\text { SO3. Improve involvement of traditional authorities }\end{array}$ & $\begin{array}{l}\text { W-O Strategies } \\
\text { WO1. Develop wildlife tracking sites close to } \\
\text { Communities } \\
\text { WO2. Elicit protection and management strategies } \\
\text { from local people (participatory management } \\
\text { approach) } \\
\text { WO3. Produce detailed ecotourism development } \\
\text { and management plan (involving local people) }\end{array}$ \\
\hline & $\begin{array}{l}\text { Threats } \\
\text { 1. Dependency of local people on forest } \\
\text { resources } \\
\text { 2. Presence of illegal users (poaching) } \\
\text { 3. Expansion of agricultural activities close to } \\
\text { protected area boundaries } \\
\text { 4. Infrastructure development } \\
\text { 5. Lack of economic benefit for local } \\
\text { communities } \\
\text { 6. Lack of resources and capacity for local } \\
\text { people to invest in tourism operations } \\
\text { 7. Crop raiding by wildlife }\end{array}$ & $\begin{array}{l}\text { S-T Strategies } \\
\text { ST1. Develop alternative ecotourism activities close to } \\
\text { major communities } \\
\text { ST2. Intensify outreach and environmental education, } \\
\text { both in schools and the communities } \\
\text { ST3. Institute local committees to support patrol staff } \\
\text { for monitoring and protection of resources } \\
\text { ST4. Provide microfinance to develop home-stay } \\
\text { facilities }\end{array}$ & $\begin{array}{l}\text { W-T Strategies } \\
\text { WT1. Establish alternative income and livelihood } \\
\text { support programmes in communities } \\
\text { WT2. Discuss and establish minimum farming } \\
\text { distance from protected area boundaries } \\
\text { WT3. Engage in joint protected area patrols with } \\
\text { local People } \\
\text { WT4. Develop mechanism to resolve wildlife-human } \\
\text { conflicts (reduce crop raining incidences) }\end{array}$ \\
\hline
\end{tabular}


should be under extra caution, follow a participatory approach with every single step justified and transparent to all the involved parties. Another threat to conservation is the human-wildlife conflicts due to crop raiding. So far, there are no mechanisms for compensating farmers when wildlife raids their food and cash crop farms. This is of serious concern to local people and communities located close to the conservation area. Reports indicate that crop raiding incidences have increased over the years. However, aside non-compensation, there has so far not been any successful mechanism to deter the wildlife. It is known that within the Kakum area, elephants are the most cited animals involved in crop raiding. Farmers have been given few strategies to deter these elephants but so far none has proven to be effective over a longer period. Some researchers have investigated the use of African honey bees to deter elephants from raiding farms with reasonable amount of success over a long period (Vollrath and Douglas-Hamilton, 2002). King (2010) and King et. al., (2010) have built on the work of Vollrath and Douglas-Hamilton (2002) and have subsequently developed a fence system where bee hives are incorporate in the fences to deter elephants from entering and raiding crops on farms in Kenya. An important aspect of this mechanism is that, aside reducing human-elephant conflicts, the bees produce honey which can be harvested and sold for additional income to support the farm households. It is envisaged that the implementation of a similar system in Kakum could reduce the incidences of crop raiding by elephants and at the same time generate sustainable income for the local people.

The $\mathbf{W}-\boldsymbol{O}$ Strategy: The number of people seeking to visit and experience natural environments as ecotourism destination is growing. Likewise, the number of people visiting Kakum has increased over the years (section 6.3.2). However, Kakum is popular mainly because of its unique canopy walk attraction which is becoming monotonous for some visitors. Hence some visitors are requesting for additional recreational options. The Kakum management authorities need to step up and develop other tourist attractions to reach a wider spectrum of tourists in order to maintain interest and patronage of the site. In a visitor survey, respondents requested among others, the development of wildlife tracking posts (see section 6.3.4b). These can be developed close to local communities to create the avenue for local people to actively participate in the planning and management of tourism activities in those sites. In order to minimise the investment cost on the Wildlife Division for developing the additional facilities, individual communities close to those areas that can be developed for ecotourism purposes could be assisted to develop ecotourism business plans with which they could use to access appropriate start-up funds for its operations. 
In the bid to improve on law enforcement, the administrative authorities can take advantage of the local people's interest to participate in conservation management. They can institute a participatory management approach, where local people are actively involved in the planning and management. They can do this by eliciting the views of the local people on protection and management strategies which will be incorporated in the existing protection mechanisms. Such an approach will boost trust and confidence among the local people, and therefore may increase their support for conservation. Caution: Since such a management mechanism is non-existent, it will require serious consultation in each of the communities alongside other relevant stakeholders to establish the modalities and the setting up of representative management groups within the communities to undertake such tasks.

The S-T Strategy: Implementing and developing ecotourism in rural communities requires initial financial investment, particularly where there are limited existing basic infrastructures in the proposed communities. Take for example the provision of home-stay services; households willing to offer such services must meet some minimum accommodation standards. However, there is an obvious lack of resources and limited capacity for the local people to do the initial investments. Any attempt to develop other ecotourism sites around the communities without adequate and targeted schemes to support the local people to do the initial investments could lead to an "elite capture". Thus, since Kakum is well publicised, few individuals and businesses could move into the communities to take advantage of the new development and reap the economic benefits to the disadvantage of the local people. Poverty coupled with lack of alternative sources to supplement livelihoods of local people can trigger negative attitudes towards conservation of the forest and wildlife resources. They may protest by intensifying illegal activities within the protected area.

In order to ensure that the local people also have a fair share of the economic benefits, households that meet certain basic requirements, to be determined, and are interested to provide home-stay services could be assisted to raise some financial capital through microfinance schemes, so they can invest appropriately to provide the requisite services to their guests. Implementing a strategy of this nature can improve on the overall Kakum experience and satisfaction among the visitors. This is also a possible way to improve on local people-tourist interaction, and therefore facilitation of intercultural appreciation. Furthermore, the involvement of local people and the provision of avenues for sharing in the economic benefits derived from conservation and ecotourism development can also create the opportunity to intensify community outreach programmes to elicit their continual support for the protection of the area. 
The S-O Strategy: In order for Kakum to continue to remain on top as the most visited tourism destination in Ghana, and an important conservation area, the authorities need to use the strengths to take advantage of the opportunities. As a unique attraction, well publicised, most visited destination and home to several species of conservation interest, the managing authorities can form partnerships with hotels, tour operators and communities to further promote Kakum. Through the partnerships, several types of tour packages could be planned to increase visitation to rural communities and the associated attractions and possibly introduce agrotourism in the conservation area. The concept of agrotourism is a direct expansion of ecotourism, which encourages visitors to experience agricultural life at first hand. The visitors will have the opportunity to work in the fields alongside real farmers to learn traditional forms of farming and animal husbandry. Agrotourism can bring about sustainable development in the participating communities. Hence, it will gather strong support from the rural communities when the local people begin to realise the associated benefits.

The administrative authorities can also use the reputation to attract and form partnerships with researchers attached to conservation institutions and universities so as to establish a biodiversity monitoring and conservation research station on-site. A permanent research station will allow for the continuous collection of relevant data on the forest and wildlife species. Analysis of time series data on the conservation area will give a better insight into the resources and therefore facilitate the development of more efficient strategies for effective protection.

\subsubsection{Application of AHP to the TOWS Strategies}

Following the construction of the TOWS framework (Table 9.4), the priorities of the strategies included in the TOWS analysis were estimated by pairwise comparison according to the steps outlined earlier. The comparison carried out in step 3 was good, yielding a consistency ratio (CR) of 3.9\% (Table 9.5). The CR measures how consistent the judgements in the pairwise comparison have been. A consistency ratio value of less than or equal to $10 \%$ is considered acceptable. Hence, a ratio greater than $10 \%(0.1)$ will require that some or all of the comparisons be repeated to resolve the inconsistencies in the pairwise comparison (Kurttila et. al., 2000; Saaty, 1977; 1980). The comparisons in step 2 however proved to be more complicated therefore producing higher consistency ratios. Nonetheless, they were all within the acceptable range and therefore indicating that the resulting priorities are logical and reliable. Refer to Appendix $6 f$ for the CR formula and to Alonso and Lamata (2006) for a detailed explanation on the CR calculations. 
The S-T group, according to these results, has the highest priority (0.503), followed by the S-O group (0.252). This is consistent with the overall priority of the factors or strategies. The top three overall priorities are distributed among the S-O, S-T and W-T strategy groups, with the first overall priority factor belonging to the S-T group (Table 9.5). Although each of the strategies presented is important, the analysis indicates that more attention should be focused on the S-T strategy, followed by the S-O strategy. Since the ratios indicate that the prioritisation of the factors or strategies were logical, they can be a good guide to help the management authorities to develop their strategic management plans and the subsequent implementations. Finding a way to initiate efforts to implement ST1, SO1, and WT4 (Table 9.5) to facilitate the achievement of the objectives that have been set for the Kakum Conservation Area as well as to fulfil the requirements of ecotourism development and management may take time. But dealing with the above prioritised strategies will also be in line with addressing some of the perceptions and opinions of the local people. The specific issues concerning the strategies are presented in section 9.3.2 as an elaboration on what could be done to improve on local people's participation in ecotourism development and protection of the conservation area.

Table 9.5 Priorities and Consistency Ratios ${ }^{\mathrm{a}}$ of Comparisons of the TOWS groups and factors (the greatest weights with respect to each TOWS group are highlighted)

\begin{tabular}{|c|c|c|c|c|c|}
\hline TOWS Group & $\begin{array}{l}\text { Priority of } \\
\text { the group }\end{array}$ & $\begin{array}{l}{ }^{b} \text { TOWS } \\
\text { factors }\end{array}$ & $\begin{array}{l}{ }^{\circ} \text { Consistency } \\
\text { ratio (CR) }\end{array}$ & $\begin{array}{l}\text { Priority of factor } \\
\text { within the group }\end{array}$ & $\begin{array}{l}\text { dOverall priority } \\
\text { of factor }\end{array}$ \\
\hline \multirow[t]{3}{*}{ so } & \multirow[t]{3}{*}{0.252} & SO1 & \multirow[t]{3}{*}{$8.4 \%$} & 0.655 & 0.165 \\
\hline & & $\mathrm{SO} 2$ & & 0.290 & 0.073 \\
\hline & & $\mathrm{SO} 3$ & & 0.055 & 0.014 \\
\hline \multirow[t]{4}{*}{ ST } & \multirow[t]{4}{*}{0.503} & ST1 & \multirow[t]{4}{*}{$9.5 \%$} & 0.577 & 0.290 \\
\hline & & ST2 & & 0.056 & 0.018 \\
\hline & & ST3 & & 0.193 & 0.028 \\
\hline & & ST4 & & 0.174 & 0.088 \\
\hline \multirow[t]{3}{*}{ WO } & \multirow[t]{3}{*}{0.063} & WO1 & \multirow[t]{3}{*}{$9.8 \%$} & 0.364 & 0.023 \\
\hline & & WO2 & & 0.537 & 0.034 \\
\hline & & WO3 & & 0.099 & 0.006 \\
\hline \multirow[t]{4}{*}{ WT } & \multirow[t]{4}{*}{0.182} & WT1 & \multirow[t]{4}{*}{$5.9 \%$} & 0.286 & 0.052 \\
\hline & & WT2 & & 0.050 & 0.009 \\
\hline & & WT3 & & 0.065 & 0.012 \\
\hline & & WT4 & & 0.599 & 0.109 \\
\hline
\end{tabular}

${ }^{\mathrm{a}}$ The consistency ratio of the comparison between four TOWS groups was $3.9 \%$

${ }^{\mathrm{b}}$ The definitions of the factors are presented in Table 9.4

'See Appendix $6 f$ for the CR calculation formula

${ }^{\mathrm{d}}$ The overall priority of the strategy factor is simply computed by multiplying the priority of the factor within the group by the priority of the group

So far, the TOWS factors displayed in the TOWS matrix (Table 9.4) and the resultant prioritisation presented in Table 9.5 are due to the existing situation that was prevailing at the time of the study. Internal and external environments are dynamic; therefore some of the factors or situation may 
change significantly over time while others within the same time frame may experience very little change. Because of the dynamics in the environment, the TOWS analysis must be conducted at periodic intervals so that management strategies can be adjusted accordingly.

\subsection{Final Remarks}

The relationship between ecotourism, local communities and natural area was assessed using a symbiotic framework (Figure 3.1; 8.1) in the Kakum Conservation Area. Unlike expected in ecotourism development, local communities around the conservation area are not enjoying any benefits from the tourism development, and the protected area is not receiving the necessary budgetary support to carry out systematic conservation related research or for conducting conservation education in the adjacent local communities. As a result, the area is also not getting adequate conservation support from the local people. The management operates independently from and without any reference to local peoples' requirements and it does not effectively involve the local people in the planning and management of the area. Likewise, tourism development is occurring with little consideration of local people or intervention from protected area managers to ensure that the local people receive some direct benefits from tourism. Presently, most efforts even at the national level are concentrated on promoting ecotourism which, is attempting to just sell the ecotourism product and increase revenue for the central government but gives little consideration to the overall quality of the experience by the tourist. Currently there is a policy vacuum concerning ecotourism development in Ghana. The overall policy vacuum stifles innovation and adaptive management which supports the emergence of real and successful ecotourism in Kakum as far as benefits to local people, investment in biodiversity conservation and visitor satisfaction are concerned.

With reference to the ecotourism framework (Figure $3.1 ; 8.1$ ), the study reveals where efforts and strengths have so far been focused. Kakum appears to have good performance concerning part of its tourism infrastructure site. The management also enforces restrictions on consumptive use but it has not promoted integrated resource use for local communities.

Although ecotourism is currently not generating benefits to local people or contributing substantially and directly to conservation efforts, it offers high-quality opportunities to enjoy and appreciate the unique tropical forest as long as it does not turn into mass tourism with the risk of irreversible environmental degradation. The Kakum example demonstrates that NGOs, both international and 
national, could play a significant role in addressing biodiversity conservation and development issues. NGOs have the capacity to assist with revenue generation, as well as facilitate community-based conservation and development. Hence, opportunities to support and strengthen the involvement of local NGOs should be urgently sought and innovative revenue-capturing mechanisms (concessions, donations, and policies to earmark funds) should be employed to increase resources for conservation and incomes or benefits for local people. In addition, re-orienting and establishing ecotourism as a complementary resource use, stepping-up environmental education, ensuring local empowerment and capacity building, operationalizing true local participation in planning and management, and promoting local pride in natural and cultural heritage are all opportunities which could motivate and encourage local people or residents to become stewards of their natural environment and resources and subsequently protect it from outsiders.

For the purposes of progressive development, strategies which would improve the protection of Kakum conservation area as well as enhance experiences for tourists and benefits for local people, should encompass formal training of field personnel, including the tour guides and patrol guards, improvement in patrolling and monitoring modalities for the conservation area, development and maintenance of reliable ecological databases, empowerment of local people through information dissemination and facilitation of involvement in decision making and benefit acquisition. The possible strategies have been presented through the TOWS analysis above.

More generally, this study has applied a theoretical framework which is based on the assumption that true ecotourism should develop synergistic relationships between tourism, biodiversity and local communities, facilitated by appropriate management strategies. Through application of the framework, the status of ecotourism in Kakum has been assessed and it has been concluded that the relationships are dysfunctional and need substantial improvement. The necessary goals for improving the performance have consequently been identified in the preceding chapters.

The framework has thus been used to guide a more holistic evaluation of ecotourism and highlighted the strengths, weaknesses and deficiencies, and consequently, drawn attention to opportunities to improve the existing situation so that the full potential of ecotourism in Kakum and, possibly, in Ghana could be achieved. Certainly, in applying the framework at other protected areas on the national level, new and site specific issues may emerge. This could be particularly evident in the development of incentive flows between the ecotourism sites and the local communities, or specific infrastructural needs, resource use demands by local people and appropriate management 
arrangements. At this point, it should be emphasised that the framework does not encompass all possible aspects of ecotourism and does not claim to address all the possible issues that could be of major concern to managers. The application rather suggests and draws attention to aspects of ecotourism, environment and society, which often could be thriving on opposing objectives. In a way it helps to generate positive outcomes through the facilitation of synergistic linkages and create a win-win situation rather than initiating and perpetuating conflicts among the relevant parties or stakeholders. Effective application of such a framework in developing ecotourism in any site could ensure that ecotourism achieves its simultaneous objective as a contributor to both biodiversity conservation and socio-economic development of local communities in the destination areas. 


\subsection{References}

Alonso, J. A. and Lamata, M. T. 2006. Consistency in the analytic hierarchy process: a new approach. International Journal of Uncertainty, Fuzziness and Knowledge based systems 14(4): 445 - 459

Harrison, S. R. 2002. Socio-economic Research Techniques in Tropical Forestry. In: Harrison, S. R., Herbohn, J.L., Mangaoang, E. O. and Vanclay, J. (eds). Socio-economic Research Methods in Forestry. A Training Manual. Rainforest CRC, Cairns.

Helms, M. M. and Nixon, J. 2010. Exploring SWOT analysis - where are we now?: A review of academic research from the last decade. Journal of Strategy and Management 3(3): $215-251$

Kangas, J., Kurtila, M., Kajanus, M. and Kangas, A. 2003. Evaluating the management strategies of a forestland estate-the S-O-S approach. Journal of Environmental Management 69: 349-358.

King, L. E. 2010. The interaction between the African elephant (Loxodonta africana africana) and the African honey bee (Apis mellifera scutellata) and its potential application as an elephant deterrent. A thesis submitted to the University of Oxford for the degree of Doctor of Philosophy in Zoology. U.K.

King, L. E., Soltis, J., Douglas-Hamilton, I., Savage, A. and Vollrath, F. 2010. Bee Threat Elicits Alarm Call in African Elephants. PLOS ONE 5(4):e10346. doi:10.1371/journal.pone.0010346

Kotler, P. 1994. Marketing Management: Analysis, Planning, Implementation and Control. Englewood Cliffs.

Kurttila, M., Pesonen, M., Kangas, J. and Kajanus, M. 2000. Utilizing the analytic hierarchy process (AHP) in SWOT analysis-a hybrid method and its application to a forest-certification case. Forest Policy and Economics 1: 41-52.

Lamarque, F., Anderson, J., Fergusson, R., Lagrange, M., Osei-Owusu, Y. and Bakker, L. 2009. Humanwildlife conflict in Africa: Causes, consequences and management strategies. FAO Forestry Paper 157. FAO Rome (ftp://ftp.fao.org/docrep/fao/012/i1048e/i1048e00.pdf )

Learned, E. P., Christensen, C. R., Andrews, K. E., and Guth, W. D. 1969. Business Policy: Text and Cases. Irwin, Homewood, IL.

Lee, J.W. and Kim, S.H. 2000. Using Analytic Network Process and Goal Programming for Interdependent Information System Project Selection. Computers and Operations Research 27: 367382.

Monney, K. A., Dakwa, K. B. and Wiafe, E. D. 2010. Assessment of crop raiding situation by elephants (Loxodonta africana cyclotis) in farms around Kakum conservation area, Ghana. International Journal of Biodiversity and Conservation 2(9): 243-249

Ramos, P., Salazar, A. and Gomes, J. 2000. Trends in Portuguese Tourism: A Content Analysis of Association and Trade Representative Perspectives. Intl. J. Contemporary Hospitality Management 12 (7): $409-416$

Saaty, T. L. 1977. A Scaling Method for Priorities in Hierarchical Structures. Journal of Mathematical Psychology 15: $234-281$ 
Saaty, T. L. 1980. The Analytical Hierarchy Process. McGraw Hill, New York

Saaty, T. L. 1990. How to Make a Decision: The Analytic Hierarchy Process. European Journal of Operational Research 48: $9-26$

Schmoldt, D.L., Kangas, J. and Mendoza, G. A. 2001. Basic Principles of Decision Making in Natural Resources and the Environment. In: Schmoldt, et. al., (eds). 2001. The Analytic Hierarchy Process in Natural Resource and Environmental Decision Making. Kluwer Academic Publishers. The Netherlands. p 1-13

Vollrath, F. and Douglas-Hamilton, I. (2002) African bees to control African elephants. Naturwissenshaften 89: 508-511.

Weihrich, H. 1982. The TOWS Matrix - A tool for situational analysis. Long Range Planning 15(2): 5466

Wildlife Department. 1996. Kakum National Park and Assin Attandanso Resource Reserve - The management plan. Accra, Ghana

Wind, Y. 1987. An analytic hierarchy process based approach to the design and evaluation of a marketing driven business and corporate strategy. Mathematical Modelling 9 (3-5): 285-291.

Wind, Y. and Saaty, T.L. 1980. Marketing applications of the analytic hierarchy process. Management Sciences 26(7): 641-658.

Wrigley, M. and Gould, B. 2002. Considering People, Adding Value, Maintaining Relevance: Strategies and tactics to Increase the Usage of Public Parks. J. Leisure Property 2(2): 142 - 154

Yüksel, Ì. and Dağdeviren, M. 2007. Using the Analytic Network Process (ANP) in a SWOT Analysis - A Case Study for a Textile Firm. Information Sciences 177: 3364 - 3382 
Appendices 
Appendix One:

Dimensions of the Impacts of Ecotourism:

A Case Study in the Kakum Conservation Area of Ghana

Questionnaire for Local Communities in the Kakum Conservation Area

Questionnaire ID Household Code

Community:

Date:

Time:

1. In what ways were you benefiting from the forest some $10-20$ years ago?

2. What livelihood activities were you undertaking before the Kakum Conservation Area was created?

3. What kinds of livelihood activities do you undertake at present?

4. How long have you been engaged in these livelihood activities? (months/ years)

5. Please indicate which one of the following means conservation to you. (Tick)

i) Preventing hunting and illegal harvesting of resources within the park boundary.

ii) Protection of wildlife and forest in and outside the boundaries of the park. ......

iii) Sustainable management of biological resources to meet needs of local people.......

6. Please respond to the following statements with the numbered answers that best suits your view:

(1 = Strongly Disagree, 2 = Disagree, 3 = Neutral, 4 = Agree, 5 = Strongly agree)

The establishment and protection of the Kakum Conservation Area:

\begin{tabular}{|c|c|c|c|c|}
\hline i) Has increased wildlife population in the area & 1 & 2 & 3 & 4 \\
\hline ii) Has improved the forest vegetation condition & 1 & 2 & 3 & 4 \\
\hline iii) Improved the local rainfall pattern & 1 & 2 & 3 & 4 \\
\hline iv) Streams and rivers are constantly flowing & 1 & 2 & 3 & 4 \\
\hline
\end{tabular}

7. Which of the following conservation initiatives are you involved? (Could be past or present)

i) Planting of tree seedlings along park boundaries .......

ii) Active involvement in decision making concerning conservation of Kakum ......

iii) Patrolling and controlling illegal activities in the park

iv) Clearing park boundaries

v) Other (please state) 
vi) None

8. Did you have contact with the wildlife officers in any of the following situations?

i) conservation education and awareness raising ... Yes / No

ii) conservation area management meetings ... Yes / No

iii) ecotourism management meetings ... Yes / No

iv) inspection of crop damage by wildlife ... Yes / No

v) other (specify)

9. Has any individuals or groups encountered difficulties or problems due to creation of the Kakum Conservation Area in this community?
i) Yes
ii) No

If yes, what kind of difficulties did these individuals or groups encounter?

10. Did the difficulties or problems affect your relationship with those individuals or groups?
i) Yes
ii) No If yes, how did it affect your relationship with them?

11. Have you noticed any changes in use of natural resources by local people after creation of the Kakum Conservation Area?
i) Yes
ii) No
If yes, what are the changes?

12. Please respond to the following statements with the numbered answers that best suits your view: ( 1 = Strongly Disagree, $\mathbf{2}=$ Disagree, $\mathbf{3}=$ Neutral, $4=$ Agree, $5=$ Strongly agree $)$

The main difficulties resulting from the creation of the Kakum Conservation Area:
i) Denied local people access to NTFPs
12
34
5
ii) Frequent intervention by Park officials
$\begin{array}{lllll}1 & 2 & 3 & 4 & 5\end{array}$
iii) Increase crop damage by wildlife

$\begin{array}{lllll}1 & 2 & 3 & 4 & 5\end{array}$
iv) Inequity in allocation of infrastructure development

$\begin{array}{lllll}1 & 2 & 3 & 4 & 5\end{array}$
v) Forest product based village industries cannot flourish

1

2
34
5

13. Please indicate the frequency of occurrences of the following statements according to your opinion and observation ( $\mathbf{1}=$ always, $\mathbf{2}=$ often, $\mathbf{3}=$ sometimes, $\mathbf{4}=$ rarely, $\mathbf{5}=$ never)
i) The park authorities are in touch with local community
1
3
4
5
ii) Local community is consulted or informed of new 
management decisions

iii) Community interest in natural resource use is

iv) Local people are involved in park boundary clearance and maintenance

v) Local people are involved in the planning of training and capacity building programmes incorporated in reviewed management plans

1

$$
2
$$$$
3
$$$$
4
$$

\section{Questions 14-24 measures effects and attitudes towards ecotourism}

14. Do you engage in livelihood activities related to ecotourism? Yes / No (if no, skip to 15)

i) If yes, which activities are they?

ii) How did you learn about the livelihood activities and how did you get started? $10-15$ years? (list)

16. Which of the infrastructure do you relate directly or indirectly to ecotourism development in Kakum?

Please circle a response that indicates your opinion on each of the following statements ( $\mathbf{1}=\mathbf{S t r o n g l y}$ Disagree, 2 = Disagree, 3 = Neutral, 4 = Agree, 5 = Strongly Agree)

17. Ecotourism in Kakum is good for my community

$\begin{array}{lllll}1 & 2 & 3 & 4 & 5\end{array}$

18. Please respond to the following statements as a direct or indirect influence of ecotourism to you and your household:

i) I personally benefit from ecotourism in Kakum

$\begin{array}{lllll}1 & 2 & 3 & 4 & 5\end{array}$

ii) I would be happy to see more tourists here

$\begin{array}{lllll}1 & 2 & 3 & 4 & 5\end{array}$

iii) I would be happy for my children to work in the tourism industry

$\begin{array}{lllll}1 & 2 & 3 & 4 & 5 \\ 1 & 2 & 3 & 4 & 5 \\ 1 & 2 & 3 & 4 & 5\end{array}$

v) My family has more money from ecotourism

19. Please indicate what level of impact tourism in the PA has on your community and livelihood ( $1=$ very good, $2=$ good, $3=$ neutral, $4=$ bad, $5=$ very bad, $6=$ don't know, $7=$ other)
i) Community
1
3
4
5
$6 \quad 7$ 
20 a) Please list job related activities that you think are opportunities for employment in ecotourism and conservation area management.

b) Which of the activities listed above would you personally like to undertake as a job?

\section{Peoples' perceptions of protected area-tourism relationships}

21. Please circle a response that indicates your perception on each of the following statements $(\mathbf{1}=$ Strongly Disagree, 2 = Disagree, 3 = Neutral, 4 = Agree, 5 = Strongly Agree)

i) Ecotourism in Kakum should be integrated with conservation and development of the local communities

$\begin{array}{lllll}1 & 2 & 3 & 4 & 5\end{array}$

ii) Ecotourism should be encouraged in other parts of the PA provided they do not conflict with $\begin{array}{llllllll}\text { conservation objectives } & 1 & 2 & 3 & 4 & 5\end{array}$

iii) The economic gains of ecotourism are as important as the protection of the PA

$\begin{array}{lllll}1 & 2 & 3 & 4 & 5\end{array}$

iv) The PA together with the animals needs greater protection

v) Increased ecotourism will not harm the PA
vi) There should be more PA establishment for conservation and ecotourism development
1

Opinions of community members about the PA and ecotourism

22. Please circle a response that indicates your opinion about the management of PA and ecotourism (1 = Strongly Disagree, 2 = Disagree, 3 = Neutral, 4 = Agree, 5 = Strongly Agree)

i) Direct involvement of local people will improve conservation of the PA

$$
\begin{array}{lllll}
1 & 2 & 3 & 4 & 5
\end{array}
$$

ii) Local peoples involvement in ecotourism management will increase tourism experience for $\begin{array}{lllllll}\text { tourists } & 1 & 2 & 3 & 4 & 5\end{array}$

iii) Current management arrangement is good enough to protect the PA

$\begin{array}{lllll}1 & 2 & 3 & 4 & 5\end{array}$

iv) PA and ecotourism linked incentives for communities will reduce illegal activities in the PA

$\begin{array}{lllll}1 & 2 & 3 & 4 & 5\end{array}$

v) Development of multiple ecotourism sites close to local communities will generate more $\begin{array}{lllllll}\text { money and incentives for local people } & 1 & 2 & 3 & 4 & 5\end{array}$

vi) Identification and development of NTFPs will increase the value of forest conservation for local people \begin{tabular}{llll|l|l}
1 & 2 & 3 & 4 & 5
\end{tabular} 174 | P a g e 
vii) Local resident people can better protect the PA from outsiders (poachers)

123

23. It is acknowledged that some of these items may have been provided by government or nongovernmental organizations. However, we are only interested in whether or not, in your opinion, the implementation of ecotourism in Kakum has resulted in improvement of these facilities (very much = 4 , much $=3$, somewhat $=2$, no $=1$ ).

i) Improvement in school facilities

$\begin{array}{llll}1 & 2 & 3 & 4 \\ 1 & 2 & 3 & 4 \\ 1 & 2 & 3 & 4 \\ 1 & 2 & 3 & 4\end{array}$

v) Improvement in health post or clinic facilities

$\begin{array}{llll}1 & 2 & 3 & 4\end{array}$

24. Please rate ecotourism in the order of: very important $=4$, important $=3$, somewhat important $=\mathbf{2}$ or not important $\mathbf{=} \mathbf{1}$ by writing a number at the end of the question.

- To what extent do you think ecotourism development is important for your community? .......

25. Please rate the effect of ecotourism in the order of: negative impact $=\mathbf{1}$, no impact $=\mathbf{2}$, positive impact $\mathbf{3} \mathbf{3}$ by writing your response number at the end of the question.

- How do you think ecotourism affects local culture and traditions?

26. Do you approve or disapprove of tourists coming to your community?

$$
\text { Disapprove }=0 . \ldots \quad \text { Approve }=1 \ldots .
$$

27. Would you approve or disapprove of increasing the size of the protected area (Kakum Conservation Area) to create sites for recreational use for tourists, even if this activity were to reduce farm lands, lead to loss of community land or displace some people?

$$
\text { Disapprove }=0 \ldots \quad \text { Approve }=1 \ldots
$$

28. Please rank the following needs that your community may have in the order of $1=$ most important, 2 = important or $\mathbf{3}$ = somewhat important.
i) Capacity development of local people .....
ii) Protection of forest and wildlife .....
iii) Community infrastructure development ....

We would appreciate if you could give some information about yourself, household and relations:

29. Status Information about respondent
i) Name of respondent:
ii) Gender: Male ...
Female ...

iii) Age of respondent: (years)
iv) Marital status: a) Single
b) Married
c) Divorced
d) Widow 
v) Level of education attained?
a) No formal education ....
b) Primary education .....c) JSS/Middle .....

d) SSS/Secondary

.... e) Post-Secondary ....

f) University ....

30. Are you a native of this community? i) Yes

ii) No

31. Were you born in this community? i) Yes

ii) $\mathrm{No}$

i) I f yes, have you lived in this community all your life? i) Yes

ii) No

ii) If No, for how long have you been living in this community? Years

32. What is your ethnic background? (e.g. Akyem, Ewe, Fanti, Ga, etc.)

33. How many are you in the household? (Household = all individuals sharing the same cooking place)

34. Do you or your household own land around the Kakum Conservation Area?
i) Yes
ii) No
a) If yes, what is the size of the land? acres

b) How did you acquire the land?
i) inheritance
ii) purchased
iii) Other (specify)

35. Did you or any member of your household have their crops damaged by wildlife?

Yes ii) No

36. Did any member of your household move out of this community in the last 5 - 10years?
i) Yes
ii) No

If yes, why did he/she move?

37. Do you have other family members or friends living in other village communities in the Kakum Conservation Area? $\quad$ i) Yes $\quad$ ii) No

a) If yes, how many are they?

b) In which community do they live? (Please specify).

c) What do they do for a living? 


\section{Dimensions of the Impacts of Ecotourism:}

\section{A Case Study in the Kakum Conservation Area of Ghana}

Questionnaire for Tourist/Visitors to the Kakum National Park

The questionnaire is administered to gather data for academic research that seeks to analyze visitor satisfaction in the Kakum Conservation Area. You are assured that the information collected will be treated confidential.

Date:

Time:

1. Is this your first visit?

Yes / No (Circle one)

If $\underline{\text { No}}$, when were you last here? (month/year)

2. How did you hear about the Kakum National Park?
i) Person recommendation ....
ii) Organized tour ...
iii) Guide book ....
iv) Promotional brochures ...
v) Internet search ...
vi) Road signs...
vii) Other

3. Did you go to other tourist attraction(s) in Ghana before visiting to Kakum? Yes / No

If yes, please list the attraction(s) and location(s):
i).
iii)
iv)

4. Will you visit other tourist attraction(s) after Kakum?

Yes / No (circle one)

If yes, please list the attraction(s) and location(s)

If no, please state your reason(s)

5. Which was your primary reason for visiting the Kakum National Park? (Please tick your response(s)).
i) Forest hiking ......
ii) Tree Canopy walk ......
iii) Opportunity to observe wildlife ......
iv) Other (please state)

6. Please respond to the following statements with the numbered answers that best suits your view:

(1 = Strongly Disagree, 2 = Disagree, 3 = Neutral, 4 = Agree, 5 = Strongly agree)

Circle the best represent your level of agreement with the statements:
a) Kakum National Park is easily accessible by road
$\begin{array}{lllll}1 & 2 & 3 & 4 & 5\end{array}$
b) I find Kakum to be well maintained and clean
$\begin{array}{lllll}1 & 2 & 3 & 4 & 5\end{array}$
c) The infrastructure is appropriate for ecotourism destination $\begin{array}{lllllll}1 & 2 & 3 & 4 & 5\end{array}$ 
d) Kakum provides a good variety for experience with nature $\begin{array}{llllll}1 & 2 & 3 & 4 & 5\end{array}$

e) There is readily available information on Park and activities $\begin{array}{lllllll}1 & 2 & 3 & 4 & 5\end{array}$

f) The exhibition at the visitor center is very informative $\quad \begin{array}{llllll}1 & 2 & 3 & 4 & 5\end{array}$

g) The visitor center is crowded $\quad \begin{array}{llllll}1 & 2 & 3 & 4 & 5\end{array}$

h) The level of interpretation by the tour guides was excellent $\begin{array}{lllllll}1 & 2 & 3 & 4 & 5\end{array}$

i) The state of the natural environment is very good $\quad \begin{array}{lllllll}1 & 2 & 3 & 4 & 5\end{array}$

j) Kakum has an interesting and varied biological diversity $\quad \begin{array}{llllll}1 & 2 & 3 & 4 & 5\end{array}$

k) I felt safe and secured during the canopy walk $\quad \begin{array}{llllll}1 & 2 & 3 & 4 & 5\end{array}$

I) The tour group for canopy walk was crowded $\quad \begin{array}{llllll}1 & 2 & 3 & 4 & 5\end{array}$

m) I was bothered by the condition of walking trails in the park $\begin{array}{llllll}1 & 2 & 3 & 4 & 5\end{array}$

n) I felt safe and secured during the forest hiking $\quad \begin{array}{llllll}1 & 2 & 3 & 4 & 5\end{array}$

o) I had a good experience with local people $\quad \begin{array}{lllllll} & 1 & 2 & 3 & 4 & 5\end{array}$

p) I had a good experience involving local culture $\quad \begin{array}{llllll}1 & 2 & 3 & 4 & 5\end{array}$

q) I had good opportunity to enjoy local cuisine $\quad \begin{array}{llllll}1 & 2 & 3 & 4 & 5\end{array}$

r) I feel I received good value for money $\quad \begin{array}{llllll}1 & 2 & 3 & 4 & 5\end{array}$

s) I enjoyed my experience in Kakum National Park $\quad \begin{array}{llllll}1 & 2 & 3 & 4 & 5\end{array}$

t) I would recommend Kakum to friends and colleagues $\quad \begin{array}{llllll}1 & 2 & 3 & 4 & 5\end{array}$

u) I would visit Kakum national Park again $\quad \begin{array}{llllll}1 & 2 & 3 & 4 & 5\end{array}$

7. How long did you spend in Kakum?
i) 0-3 hrs ...
ii) 3-6 hrs ...
iii) 6-12 hrs ...
iii) $>12$ hrs...

8. Were there any activities you expected but did not find in Kakum and the surrounding areas?
Yes / No
If yes, please list: i).
ii).

9. If you return to Kakum, what will you do again?

10. What would you not do?

11. Would you like anything changed or improved to enhance your next vacation and experience in Kakum National Park? Yes /No

If yes, what would you like changed or improved? 
12. We would appreciate if you could provide us with a few details about yourself.
i) Gender: Male / Female
ii) Age:

iii) Occupation:

iv) Level of Formal Education:

v) City or Town and Country of Residence:

vi) Did you come in a group? Yes /No (Circle)

vii) If yes, number in group:
viii) Is the group a family?
Yes / No (circle)

Thank you for your participation and valuable contribution to the study. 


\section{Dimensions of the Impacts of Ecotourism:}

\section{A Case Study in the Kakum Conservation Area of Ghana}

Guide Questions for Informants, Community Leaders and Group Discussions

1. How important was the forest to this community and inhabitants?

2. What livelihood activities were you undertaking before the Kakum Conservation Area was formed?

3. Do you think it was necessary to strictly protect the forest and wildlife in Kakum?

4. Are the community leaders and members involved in decisions concerning the management of the conservation area?

5. Do you think there is adequate conservation education and awareness creation in the community?

6. How does local knowledge feature in conservation education and management of the conservation area?

7. How has the needs of local people been incorporated in the management of Kakum?

8. Do you think the population of wildlife has increased in Kakum compared to the last $10-20$ years?

9. What do you make of the wildlife crop damage incidences in the last $10-15$ years?

i) Would you say it has increased or decreased?

ii) What would you recommend to reduce the frequency of incidence if not eliminated?

10. How were you involved in the implementation of ecotourism in the Kakum Conservation Area?

11. What are your expectations of the ecotourism initiative in Kakum?

12. Would you say that ecotourism has contributed to infrastructure development in this community?

13. Would you say that ecotourism has had some impact on social norms in this community?

i) If so, why? (Reasons)

ii) Do you think these impacts will develop and affect the community in a positive or negative way?

14. In what ways has ecotourism had impact on your social networks within and out of the community?

15. What are your recommendations to improve ecotourism and its benefits to the community? 
Dimensions of the Impacts of Ecotourism:

A Case Study in the Kakum Conservation Area of Ghana

Guide for interviews with Park Officials and Institutions Promoting Ecotourism and Conservation in Kakum Conservation Area

1. What are the most important issues in the conservation of biodiversity in Ghana?

2. Do you consider tourism as an incentive for conservation?

3. Why is the Wildlife Division of the Forestry Commission promoting ecotourism in protected areas in Ghana?

4. What is ecotourism from the perspective of the Wildlife Division/Forestry Commission?

5. Why was ecotourism implemented particularly in the Kakum Conservation Area?

6. What were the original aims and objectives for implementing ecotourism in Kakum?

7. What have been the main obstacles in promoting ecotourism in Kakum?

8. Do you think the objectives are being met?

9. Has ecotourism contributed to conservation of the national Park?

10. Has ecotourism contributed to development of the local communities in Kakum Conservation Area?

11. Are the local people engaged in activities that enhance ecotourism?

12. What are the mechanisms for managing ecotourism activities in the area and Ghana as a whole?

13. Does Ghana have the right policy framework to promote ecotourism?

14. What is the prospect of ecotourism in Ghana? 


\section{Appendix Five:}

General Criteria and Indicators for Ecotourism Assessment

\begin{tabular}{|c|c|c|c|c|}
\hline & Criteria & Indicators & Measurement & Reference \\
\hline 1 & $\begin{array}{l}\text { Enhance Conservation of biological } \\
\text { diversity } 1(148) ; 3(62) ; 5(125) ; 10(9) \\
\text { Money transfers! } \\
\text { Tourism income }\end{array}$ & $\begin{array}{l}\text { - Habitat and spp diversity }{ }^{1(148) ; 10(22)} \\
\text { - Flora and Fauna spp richness, evenness and } \\
\text { composition }{ }^{1(148)} \\
\text { - Abundance of faunal population (birds, } \\
\text { mammals, etc) }{ }^{1(148)} \\
\text { - No. of threatened and endangered spp }{ }^{1(148) ;} \\
\text { - No. of endemic flora and fauna } \\
\text { Park inventory / zonation }\end{array}$ & $\begin{array}{l}\text { - Shannon Index; Simpson Index }{ }^{1(148)} \\
\text { - list and No. of spp., relative frequency, } \\
\text { relative density, equitable index }{ }^{1(148)} \\
\text { - Density (no./area), population counts, } \\
\text { sign/area, auditory/area, linear density } \\
\text { (no./line distance) }{ }^{1(148)} \\
\text { - list and no. of endangered spp., \% } \\
\text { endangered to total native spp., \% of animal } \\
\text { spp. threatened }{ }^{1(148)} \\
\text { - list and no. of endemic spp, } \% \text { endemic to } \\
\text { total native spp }{ }^{1(148)}\end{array}$ & $\begin{array}{l}{ }^{5} \text { Ross and Wall, } \\
\text { 1999a:125 } \\
{ }^{10} \text { Wood, } 2004: 9 \text {, } \\
22\end{array}$ \\
\hline 2 & $\begin{array}{l}\text { Protection of Environment from } \\
\text { degradation } 1(148) ; 3(62) ; 5(125) ; 7(426) ; 11(41)\end{array}$ & $\begin{array}{l}\text { - Clearly demarcated boundary }{ }^{1(148) ; 10(22)} \\
\text { - \% designated wilderness area }{ }^{1(148)} \\
\text { - effective protection of wilderness, } \\
\text { watersheds, habitats, biodiversity and } \\
\text { ecosystem } \\
\text { - ecosystem management and research } \\
\text { programme }{ }^{5(130)} \\
\text { - No. of illegal encroachments and land } \\
\text { alterations }{ }^{1(148) ; 10(22)}\end{array}$ & $\begin{array}{l}\text { - \% of forest cover, \% of park effectively } \\
\text { protected, \% preserved as wilderness and } \\
\text { buffer area, \% extreme sensitive area } \\
\text { protected } \\
\text { - no. of encroachment, size of area, habitat } \\
\text { type loss }{ }^{1(148)} \\
\text { - \% fund allocated for research and } \\
\text { conservation } \\
\text { - habitat loss as a \% of park's total area }{ }^{1(148)}\end{array}$ & $\begin{array}{l}{ }^{5} \text { Ross and Wall, } \\
\text { 1999a: } 125,130\end{array}$ \\
\hline
\end{tabular}




\begin{tabular}{|c|c|c|c|c|}
\hline & & $\begin{array}{l}\text { - Size and \% of bare/impacted/degraded land } \\
1(148) \\
\text { - Rehabilitation of wildlife plots, trails, } \\
\text { waterways and tourism sites } 1(148) \\
\text { - revenue to contribute to protection and } \\
\text { management of PA and habitats } 5(125) ; 10(22) \\
\text { - Public awareness programme for low } \\
\text { impact activities } \\
\text { - limit/control no. of hikers in critical area } \\
\text { 1(148); 10(22) } \\
\text { - population per sq. meter village area }\end{array}$ & $\begin{array}{l}\text { - \% marked and well maintained boundary } \\
1(148) \\
\text { - amount and \% allocation of annual budget, } \\
\text { no. of complaints/compliment } 1(148) ; 5(125) \\
\text { - available conservation education } \\
\text { programme, \% ecotourist/low impact user, } \\
\text { available low impact regulation }{ }^{1(148)}\end{array}$ & $\begin{array}{l}{ }^{7} \text { Sirakaya et. al. } \\
\text { 2001:426 } \\
{ }^{10} \text { Wood, 2004:22 } \\
{ }^{11} \text { WTO 2007:41 }\end{array}$ \\
\hline 3 & $\begin{array}{l}\text { Carrying Capacity of tourism } \\
\text { resources/Overcrowding 1(148-9); 4; 7(426); } \\
10(7) ; 11(58)\end{array}$ & $\begin{array}{l}\text { - Limits of acceptable change (LAC) to critical } \\
\text { wildlife areas (feeding areas, water holes) } \\
\text { - \% of park area used for ecotourism } \\
\text { - No. of tourists (year, month, season, weekly } \\
\text { and weekend) } \\
\text { - No. of tourist service facilities and } \\
\text { infrastructure } \\
\text { - concentration zones and use intensity of } \\
\text { designated ecotourism activity areas }\end{array}$ & $\begin{array}{l}\text { - \% degraded, frequency of wildlife sightings, } \\
\text { size of protected habitat } \\
\text { - distribution of wildlife sightings in } \\
\text { designated tourist activity areas } \\
\text { - \% tourism development area, \% of site for } \\
\text { visitor use } \\
\text { - available measures to set seasonal limits, \% } \\
\text { visiting main attraction, total annual no., } \\
\text { peak day/month nos., ratio of tourists to } \\
\text { locals } \\
\text { - length of wait in low/high season } \\
\text { - No. of tourists per sq. meter of site }\end{array}$ & $\begin{array}{l}{ }^{1} \text { Abidin, 1999:148- } \\
9 \\
{ }^{3} \text { Ceron, 2003:62 } \\
{ }^{4} \text { Eagles, et. al. } \\
2002 \\
{ }^{7} \text { Sirakaya et. al. } \\
{ }^{2001: 426} \\
{ }^{10} \text { Wood, 2004: } 7 \\
{ }^{11} \text { WTO 2007:58 }\end{array}$ \\
\hline
\end{tabular}




\begin{tabular}{|c|c|c|c|c|}
\hline & & & - Mean No. per peak period average & \\
\hline 4 & $\begin{array}{l}\text { Enabling Environment (institutional } \\
\text { framework) for conservation and } \\
\text { ecotourism development } \\
\text { 1(149); 10(17) }\end{array}$ & $\begin{array}{l}\text { - Policy, legislation and law enforcement }{ }^{1(149) ;} \\
\text { - Management plan and implementation }{ }^{1(149) ;} \\
\text { 10(17,23) } \\
\text { - Research and monitoring programmes }{ }^{1(149) ;} \\
\text { 10(17,22) } \\
\text { - Tourist code of ethics } \\
\text { - Staff performance and capacity building } \\
\text { - Participatory programmes that include local } \\
\text { people }{ }^{10(23)} \\
\text { - capacity building for local people }\end{array}$ & $\begin{array}{l}\text { - existence of policy and law, and } \\
\text { enforcement capability } \\
\text { - existence of management plan } \\
\text { - existence of research and monitoring } \\
\text { program } \\
\text { - existence of tourist code of ethics } \\
\text { - available training opportunity and } \\
\text { promotion } \\
\text { - existence of community participatory and } \\
\text { outreach programmes } \\
\text { - training programmes }\end{array}$ & $\begin{array}{l}{ }^{10} \text { Wood, 2004:17, } \\
22-3\end{array}$ \\
\hline 5 & $\begin{array}{l}\text { Participation of local people in park } \\
\text { and sustainable tourism management } \\
1(151) ; 10(17,18) ; 11(57)\end{array}$ & $\begin{array}{l}\text { - locals employed for conservation and } \\
\text { provision of ecotourism services } \\
\text { - no. of participatory park and tourism } \\
\text { advisory meetings involving local } \\
\text { communities } \\
\text { - local support of protected area } \\
\text { management and ecotourism }\end{array}$ & $\begin{array}{l}\text { - local unemployment rate, no. and \% } \\
\text { employed, no. in tourism related jobs, no. in } \\
\text { conservation related jobs } \\
\text { - no. of meetings involving locals, \% of local } \\
\text { representatives involved in meetings } \\
\text { - \% local people who believe tourism has } \\
\text { help bring new services and infrastructure } \\
\text { - No. and capacity of social services available } \\
\text { to community (\% attributed to tourism) } \\
\text { - no. of park offences by locals, no. of } \\
\text { complaints by locals }\end{array}$ & $\begin{array}{l}{ }^{1} \text { Abidin, 1999:151 } \\
{ }^{10} \text { Wood, 2004:17, } \\
18\end{array}$ \\
\hline
\end{tabular}




\begin{tabular}{|c|c|c|c|c|}
\hline 6 & $\begin{array}{l}\text { Sustained and adequate funding }{ }^{1(144,} \\
149) ; 10(6,22)\end{array}$ & $\begin{array}{l}\text { - Long-term management and development } \\
\text { budget } 1(144,149) ; 10(6,22) \\
\text { - Consistent yearly administrative budget } \\
\text { - Governmental source funding } \\
\text { - Entrance fees collected }{ }^{5(130)} \\
\text { - Ability to use tourism revenue } \\
\text { - Donation programme } \\
\text { - Trust fund specific for ecotourism } \\
\text { development and conservation } \\
\text { - training, extension and research funding }\end{array}$ & $\begin{array}{l}\text { - available sustained and adequate funding, } \\
\text { amount spent on operation and } \\
\text { development } \\
\text { - amount and \% of total annual budget for } \\
\text { conservation } \\
\text { - \% government fund per total budget }\end{array}$ & $\begin{array}{l}{ }^{1} \text { Abidin, 1999:144, } \\
149 \\
{ }^{5} \text { Ross and Wall, } \\
1999 a: 130 \\
{ }^{10} \text { Wood, 2004: 6, } \\
22\end{array}$ \\
\hline 7 & $\begin{array}{l}\text { Maintain local social, culture, religion } \\
\text { and historical values } 1(150) ; 3(62) ; 10(16,23)\end{array}$ & $\begin{array}{l}\text { - historical activities and use of natural areas } \\
\text { (protected area) by local people }{ }^{5(125)} \\
\text { - cultural/religious activities } \\
\text { - traditional values of natural resources for } \\
\text { local people } \\
\text { - familial cohesion and values }{ }^{5(125)} \\
\text { - exposure and flexibility to change }{ }^{5(125)} \\
\text { - tourism activities that provide opportunities } \\
\text { to learn about local culture }{ }^{8(374)} \\
\text { - communal/ social programmes } \\
\text { - community cohesion }\end{array}$ & $\begin{array}{l}\text { - past and present use/consumptive } \\
\text { activities in and around protected area } \\
\text { - changes in cultural/religious activities in } \\
\text { communities } \\
\text { - perceived values of natural resources by } \\
\text { local people } \\
\text { - average size of family and out-migration of } \\
\text { youth } \\
\text { - perception and acceptance of changes in } \\
\text { livelihood activities } \\
\text { - no. and frequency of cultural related } \\
\text { ecotourism activities } \\
\text { - frequency and types of communal activities }\end{array}$ & $\begin{array}{l}{ }^{1} \text { Abidin, 1999:150 } \\
{ }^{3} \text { Ceron, 2003:62 } \\
{ }^{5} \text { Ross and Wall, } \\
\text { 1999a:125 }\end{array}$ \\
\hline
\end{tabular}




\begin{tabular}{|c|c|c|c|c|}
\hline & & & $\begin{array}{l}\text { of local people } \\
\text { - value and respect for traditional culture } \\
\text { - cooperation/competition among } \\
\text { individuals, families or groups for perceived } \\
\text { benefits of ecotourism }\end{array}$ & ${ }^{9}$ Wood, 2004:16 \\
\hline 8 & $\begin{array}{l}\text { Benefits / Sustainability of livelihood } \\
\text { of local people } 2 ; 3(62) ; 7(426) ; 10(8,15)\end{array}$ & $\begin{array}{l}\text { - infrastructure, health and education } \\
\text { development for local people } 1(150) ; 5(125) \\
\text { - No. of ecotourism services providers } \\
\text { - livelihood activities of local people } \\
\text { - income from tourism arrangement work }{ }^{2 ;} \\
10(8,15) \\
\text { - Human population in the park and } \\
\text { surrounding areas } \\
\text { - Activities of people in protected area and } \\
\text { surroundings } \\
\text { - people involved in NTFP livelihood activities } \\
\text { - Equity in benefit sharing }{ }^{10(8,15)} \\
\text { - local distribution of ecotourism benefits } \\
5(125) \\
\text { - local capacity building towards self- } \\
\text { sufficiency/local empowerment } \\
5(125) \\
\text { - use of locally produced goods and services } \\
8(374)\end{array}$ & $\begin{array}{l}\text { - infrastructure, housing, school, public } \\
\text { transportation, utility, health and security } \\
\text { expenditures per capita } \\
\text { - comparable density of development (\% of } \\
\text { tourist facilities) } \\
\text { - No. and \% of households providing services } \\
\text { (records and survey interviews) } \\
\text { - no. of people within 5-10km of park } \\
\text { boundary involved in NTFP livelihood } \\
\text { activities } \\
\text { - \% of park area affected by adverse human } \\
\text { activity (squatting, wood cutting etc) } \\
\text { - \% of surrounding land used for human } \\
\text { agriculture and other purposes (5-10km } \\
\text { from boundary) } \\
\text { - frequency and kinds of local products and } \\
\text { services used } \\
\text { - census data, \% change in population size }\end{array}$ & $\begin{array}{l}{ }^{2} \text { Bhattacharya anc } \\
\text { Kumari. } 2004 \\
{ }^{3} \text { Ceron, 2003:62 } \\
{ }^{5} \text { Ross and Wall, } \\
\text { 1999a:125 } \\
{ }^{7} \text { Sirakaya et. al. } \\
{ }^{2001: 426} \\
\\
{ }^{8} \text { Twining-Ward } \\
\text { and Butler. } \\
2002: 374 \\
{ }^{10} \text { Wood, 2004:8, }\end{array}$ \\
\hline
\end{tabular}




\begin{tabular}{|c|c|c|c|c|}
\hline & & $\begin{array}{l}\text { - support and development of quality local } \\
\text { craft for potential income-generation } \\
\text { - Out-migration status of communities }\end{array}$ & & 15,16 \\
\hline 9 & $\begin{array}{l}\text { Promote conservation education and } \\
\text { public awareness }\end{array}$ & $\begin{array}{l}\text { - interpretive centre with library and exhibits } \\
1(150) ; 10(12-3,16,23) \\
\text { - environmental education programmes in } \\
\text { park and local schools } \\
\text { - ecological and sustainability knowledge } \\
\text { among public } \\
\text { - local people support for conservation }{ }^{5(125)} \\
\text { - communities participating in local area } \\
\text { conservation }^{8(373)}\end{array}$ & $\begin{array}{l}\text { - functional interpretive programme } \\
\text { - no. and frequency of extension } \\
\text { programme, \% fund allocated for } \\
\text { conservation education } \\
\text { - local people participation in conservation } \\
\text { activities } \\
\text { - \% knowledgeable in conservation and uses } \\
\text { of surrounding natural resources } \\
\text { (questionnaire survey) } \\
\text { - attitudes towards conservation } \\
\text { - perceptions of value of natural resources }\end{array}$ & $\begin{array}{l}{ }^{1} \text { Abidin, 1999:150 } \\
\text { }{ }^{5} \text { Ross and Wall, } \\
\text { 1999a:125 } \\
\\
{ }^{8} \text { Twining-Ward } \\
\text { and Butler. } \\
\text { 2002:373 } \\
{ }^{10} \text { Wood, 2004: 12 } \\
3,16,23\end{array}$ \\
\hline 10 & Tourist and local people satisfaction & $\begin{array}{l}\text { - availability of alternative ecotourism } \\
\text { activities at location } \\
\text { - No. of complaints by tourists } \\
\text { - use intensity } \\
\text { - tourists willingness to pay for recreation } \\
\text { - tourists perception of the park } \\
\text { - \% satisfied tourists }\end{array}$ & $\begin{array}{l}\text { - no. of alternative activities and frequency } \\
\text { of patronage } \\
\text { - no. of tourist complaints and compliment, } \\
\text { ratio of complaint to compliment, action } \\
\text { taken to remedy the problem } \\
\text { - high and consistent willingness to pay } \\
\text { - \% perception of environmental health, } \\
\text { danger, cleanliness, conservation, quality of } \\
\text { tourism }\end{array}$ & $\begin{array}{l}{ }^{1} \text { Abdin, 1999:151 } \\
{ }^{3} \text { Ceron, 2003:62 } \\
\text { Sirakaya et. al. } \\
\text { 2001:427 } \\
{ }^{11} \text { WTO 2007:35, }\end{array}$ \\
\hline
\end{tabular}




\begin{tabular}{|c|c|c|c|c|}
\hline & & $\begin{array}{l}\text { - quality of facilities, services and activities } \\
\text { - perception of value for money } \\
\text { - \% of repeat tourists } \\
\text { - No. of complaints by local people } \\
\text { - local people perception of tourism activities } \\
\text { in protected area }\end{array}$ & $\begin{array}{l}\text { - \% satisfied visitors (questionnaire survey) } \\
\text { - attractiveness of main tourism activities } \\
\text { - No. and type of complaints by local people }\end{array}$ & 57 \\
\hline 11 & Development and Land use planning & $\begin{array}{l}\text { - integrated use zones }{ }^{5(130)} \\
\text { - type of allowable land use activities in the } \\
\text { park and surrounding area } \\
\text { - allowable no. of visitors } \\
\text { - existence of land use/development planning } \\
\text { process, including tourism } \\
5(130) ; 8(375)\end{array}$ & $\begin{array}{l}\text { - type, no. and \% non-sustainable tourism } \\
\text { activities, \% low density tourist facilities } \\
\text { - available set limits to attraction, no. of } \\
\text { localities classified as hot spots for tourism, } \\
\text { average visitor no./day } \\
\text { - \% of area subject to control (density, } \\
\text { infrastructure design etc) }\end{array}$ & $\begin{array}{l}{ }^{1} \text { Abidin, 1999:151- } \\
2 \\
{ }^{5} \text { Ross and Wall, } \\
\text { 1999a:130 } \\
\\
{ }^{8} \text { Twining-Ward } \\
\text { and Butler. } \\
\text { 2002:375 } \\
{ }^{11} \text { WTO 2007:58 }\end{array}$ \\
\hline
\end{tabular}




\section{References}

1. Abidin, Z. Z. 1999. The Identification of Criteria and Indicators for the Sustainable Management of Ecotourism in Taman Negara National Park, Malaysia: A Delphi Consensus. Ph.D Dissertation. p 148152

2. Bhattacharya, Prodyut and Kumari, Smriti. 2004. Application of Criteria and Indicator for Sustainable Ecotourism: Scenario under Globalization. Abstract and Paper submitted for the IASCP Bi-Annual Conference on "The Commons in an Age of Global Transition: Challenges, Risks and Opportunities" at Oaxaca, Mexico from 9-14 August, 2004 (06.06.2008)

3. Ceron, J.-P. 2003. Tourism and Sustainable Development Indicators: The Gap between Theoretical Demands and Practical Achievements. Current Issues in Tourism 6(1): 54-75

4. Eagles, P., McCool, S. F. and Haynes, C. D. 2002. Sustainable Tourism in Protected Areas. IUCN 2002, Gland, Switzerland

5. Ross, S. and Wall, G. 1999a. Ecotourism: towards congruence between theory and practice. Tourism Management 20(1): 123-132

6. Ross, S. and Wall, G. 1999b. Evaluating Ecotourism: The Case of North Sulawesi, Indonesia. Tourism Management 20: 673-682

7. Sirakaya, E., Jamal, T. B., and Choi, H.-S. 2001. Developing Indicators for Destination Sustainability. In: Weaver, D. B. (ed). The Encyclopaedia of Ecotourism. CAB International. p 411-432 (09.06.2008)

8. Twining-Ward, L. and Butler, R. 2002. Implementing STD on a Small Island: Development and Use of Sustainable Tourism Development Indicators in Samoa. Journal of Sustainable Tourism 10(5):363387 (http://www.multilingual-matters.net/jost/010/0363/jost0100363.pdf) (14.07.2008)

9. Wallace, G. N. and Pierce, S. M. 1996. An Evaluation of Ecotourism in Amazonas, Brazil. Annals of Tourism Research 23(4): 843-873

10. Wood, M. E. 2004. An Ecotourism Project Analysis \& Evaluation Framework for International Development Donors: Defining Indicators for Conservation, Community and Local Enterprise Development. Epler Wood International. 27pp

11. WTO 2007. Workshop on Indicators of Sustainable Development for Tourism Destinations. Lombok, Indonesia, 21-24 March 2007. Summary Report. Pp86 (www.worldtourism.org/sustainable/doc/Lombok-Indicators-2007.pdf) (20.062008) 
Appendix Six: Details of the Outputs in the Analytical Hierarchy Process Analyses

\section{6a) Comparison and Ranking of the Strategy Groups}

AHP Analytic Hierarchy Process (EVM multiple inputs)

K. D. Goepel Version 08.05.2013 http://bpmsg.com

Only input data in the light green fields and worksheets!

\begin{tabular}{|c|c|c|c|c|}
\hline$n=[$ & Number of criteria (3 to 10 ) & Scale:[ & & Linear \\
\hline 1 & Number of Participants ( 1 to 20 ) & $\alpha: 0.15$ & Consensus: & $n / a$ \\
\hline 0 & selected Participant $(\mathrm{O}=$ consol. $)$ & 7 & Consolidated & \\
\hline
\end{tabular}

Objective Strategy - to increase communitiy participation in ecotourism and improve conservation management

Author Fiagbomeh

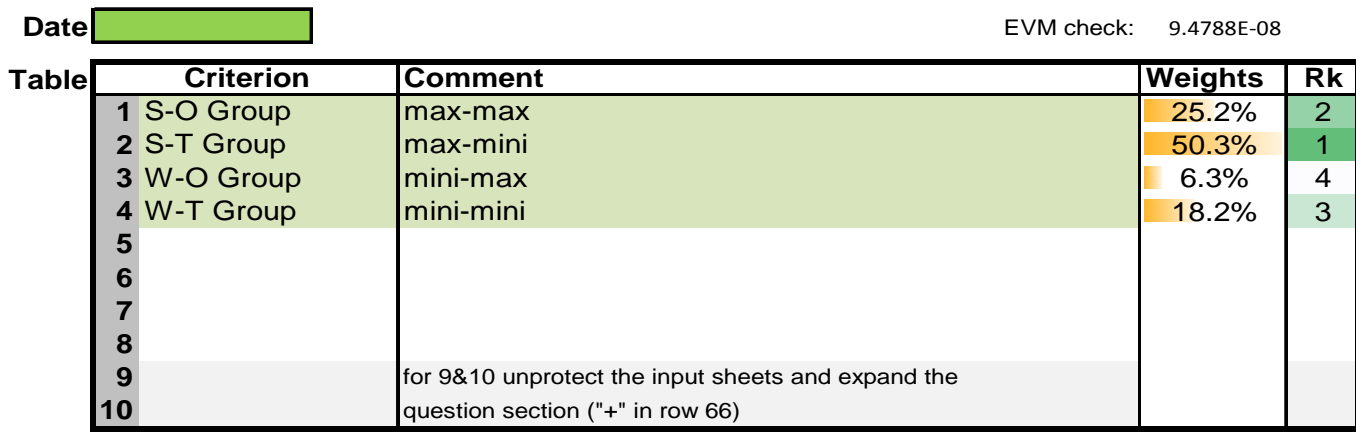

\begin{tabular}{|c|c|c|c|c|c|}
\hline \multirow[t]{2}{*}{ Result } & \multicolumn{3}{|l|}{ Eigenvalue } & \multirow[t]{2}{*}{ lambda: } & 4.107 \\
\hline & Consistency Ratio & 0.37 & GCI: 0.14 & & $3.9 \%$ \\
\hline
\end{tabular}

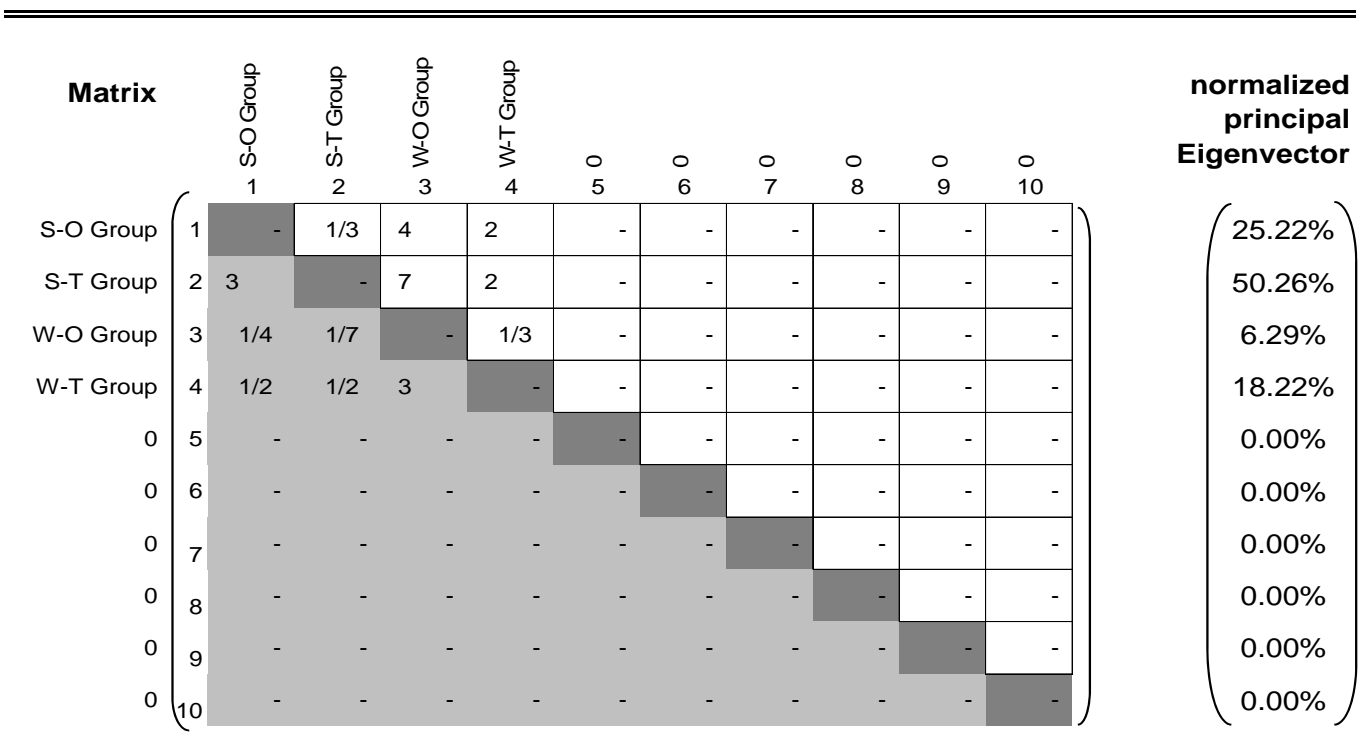


AHP Analytic Hierarchy Process

$n=4$

Input 1

Objective: Strategy - to increase communitiy participation in ecotourism and improve conservation management

Only input data in the light green fields!

Please compare the importance of the elements in relation to the objective and fill in the table: Which element of

each pair is more important, $\mathbf{A}$ or $\mathbf{B}$, and how much more on a scale 1-9 as given below.

Once completed, you might adjust highlighted comparisons 1 to 3 to improve consistency.

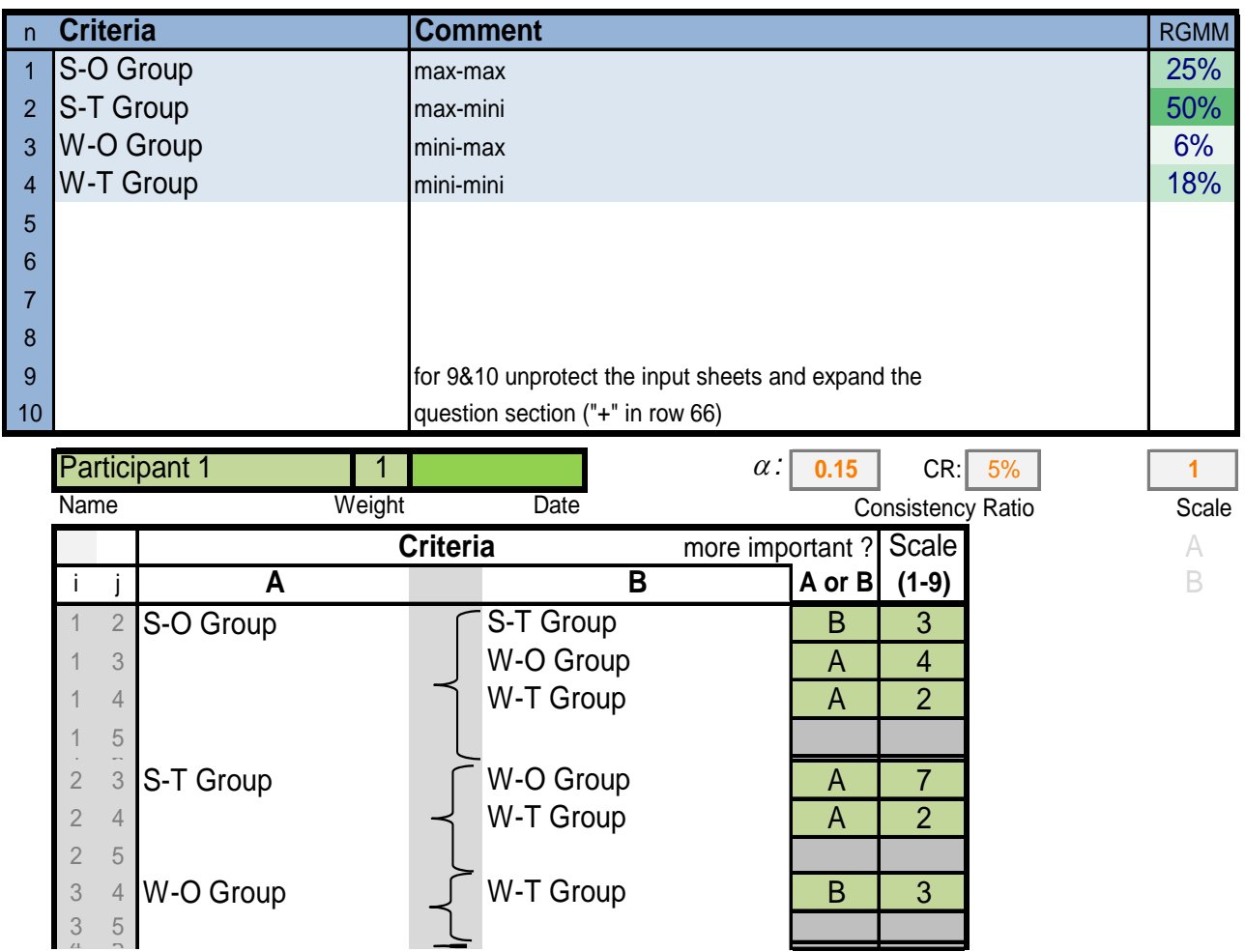

\begin{tabular}{|c|l|l|}
\hline Intensity & Definition & Explanation \\
\hline $\mathbf{1}$ & Equal importance & Two elements contribute equally to the objective \\
\hline $\mathbf{3}$ & Moderate importance & Experience and judgment slightly favor one element over another \\
\hline $\mathbf{5}$ & Strong Importance & $\begin{array}{l}\text { Experience and judgment strongly favor one element over } \\
\text { another }\end{array}$ \\
\hline $\mathbf{7}$ & $\begin{array}{l}\text { Very strong } \\
\text { importance }\end{array}$ & $\begin{array}{l}\text { One element is favored very strongly over another, it dominance } \\
\text { is demonstrated in practice }\end{array}$ \\
\hline $\mathbf{9}$ & Extreme importance & $\begin{array}{l}\text { The evidence favoring one element over another is of the highest } \\
\text { possible order of affirmation }\end{array}$ \\
\hline $2,4,6,8$ can be used to express intermediate values \\
\hline
\end{tabular}


6b) Comparison and Ranking of the Strengths-Opportunities (S-O) Strategy factors

AHP Analytic Hierarchy Process (EVM multiple inputs)

K. D. Goepel Version 08.05.2013 http://bpmsg.com

Only input data in the light green fields and worksheets!

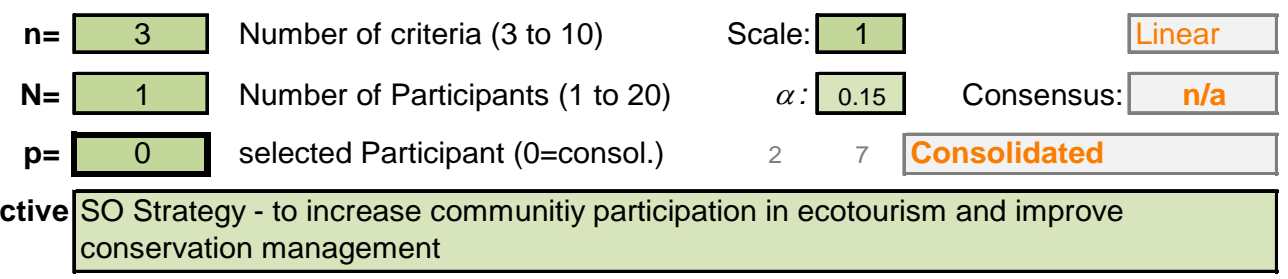

Author Fiagbomeh

Date

EVM check: $4.02876 \mathrm{E}-06$

\begin{tabular}{|l|l|l|c|c|}
\hline \multicolumn{1}{|c|}{ Criterion } & Comment & Weights & Rk \\
\cline { 2 - 5 } & $\mathbf{1}$ SO1 & form partnerships for package tours & $65.5 \%$ & 1 \\
& 2 SO2 & form partnerships with universities & $29.0 \%$ & 2 \\
$\mathbf{3}$ SO3 & improve involvement of traditional authorities & $5.5 \%$ & 3 \\
$\mathbf{4}$ & & & \\
$\mathbf{5}$ & & & \\
$\mathbf{6}$ & & & \\
$\mathbf{7}$ & for 9\&10 unprotect the input sheets and expand the & \\
$\mathbf{9}$ & question section ("+" in row 66) & & \\
$\mathbf{1 0}$ & & & & \\
\hline
\end{tabular}

\begin{tabular}{|c|c|c|c|c|c|c|}
\hline \multirow[t]{2}{*}{ Result } & Eigenvalue & & & & lambda: & 3.080 \\
\hline & Consistency Ratio & 0.37 & GCI: & 0.24 & & CR: $8.4 \%$ \\
\hline
\end{tabular}

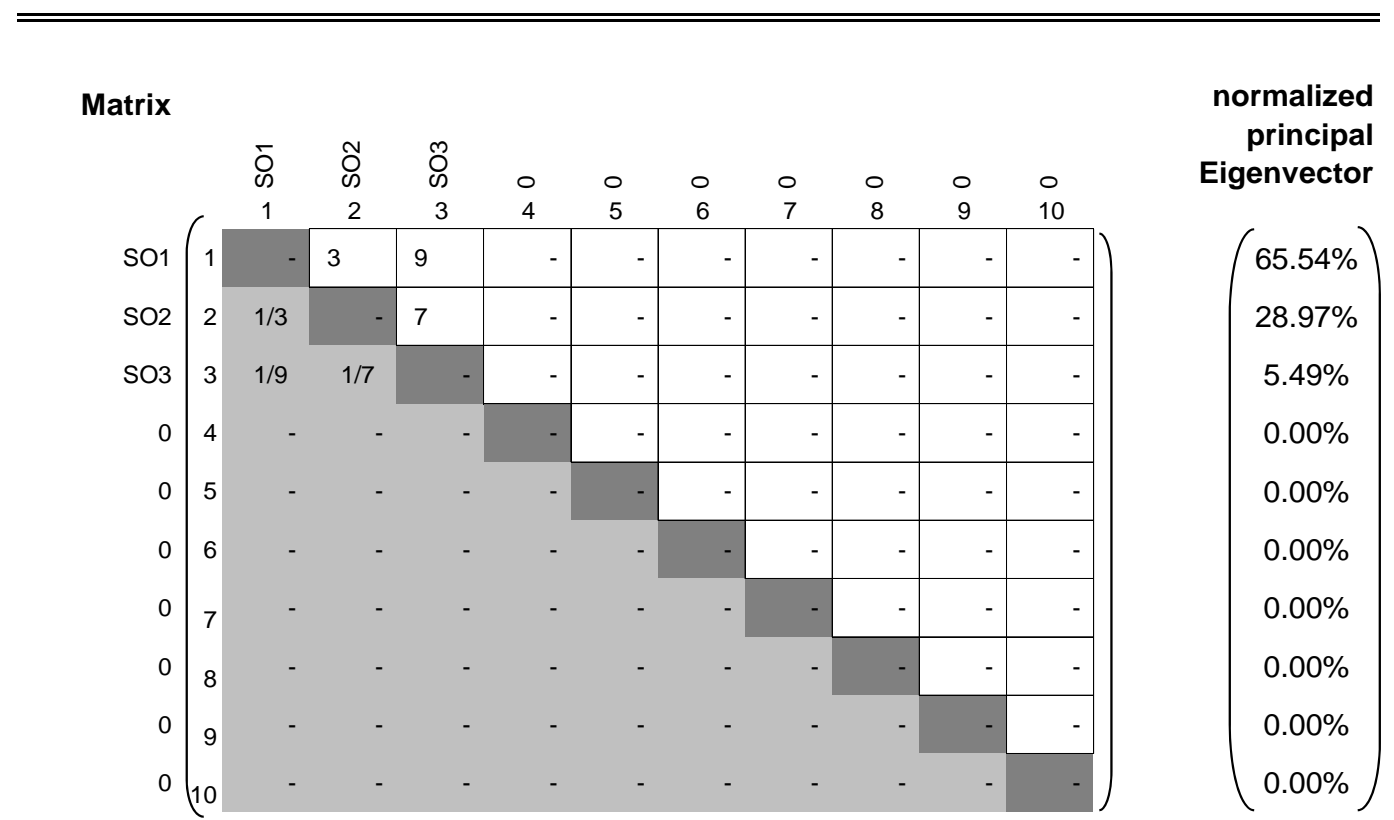


AHP Analytic Hierarchy Process

$n=3$

Input 1

Objective: SO Strategy - to increase communitiy participation in ecotourism and improve conservation managen

Only input data in the light green fields!

Please compare the importance of the elements in relation to the objective and fill in the table: Which element of

each pair is more important, $\mathbf{A}$ or $\mathbf{B}$, and how much more on a scale 1-9 as given below.

Once completed, you might adjust highlighted comparisons 1 to 3 to improve consistency.

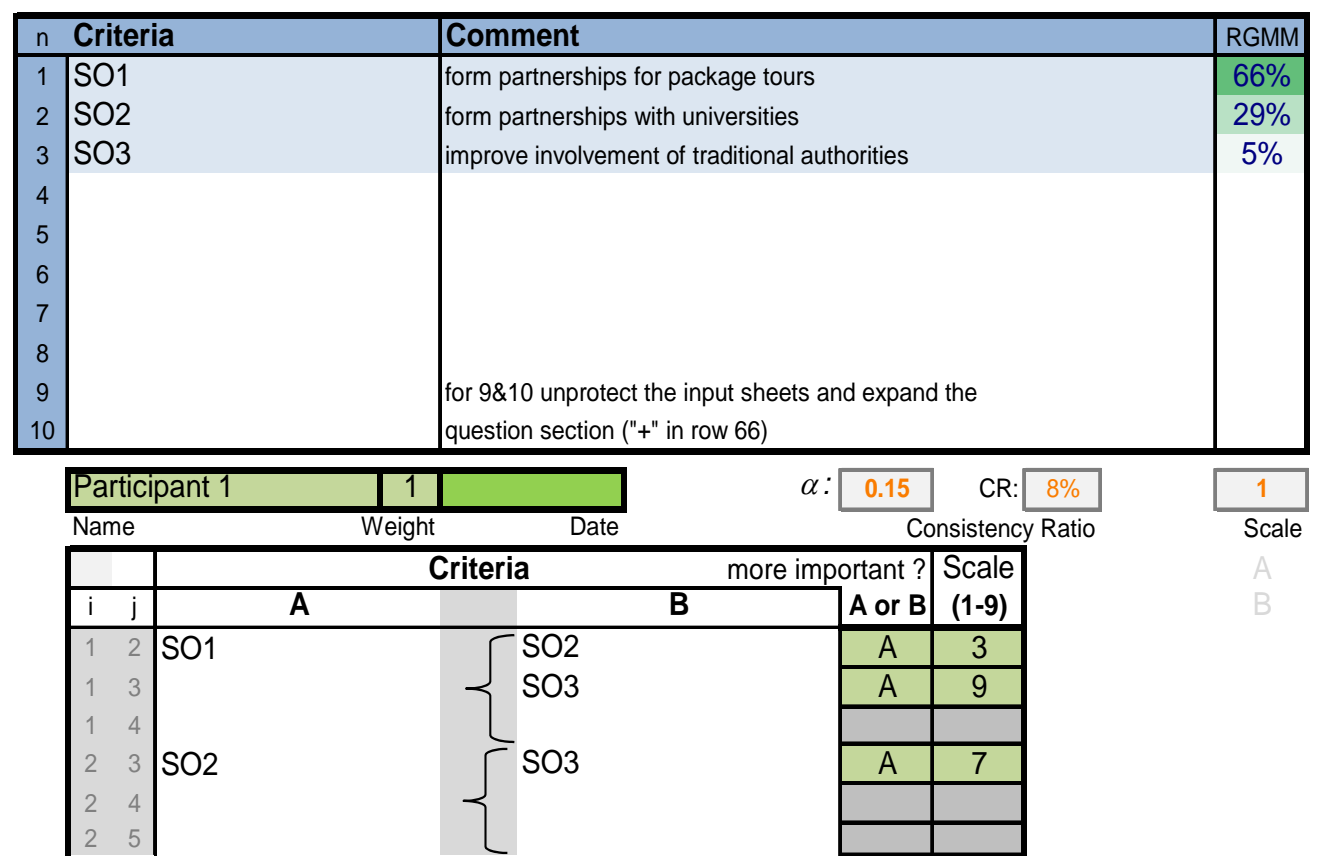

\begin{tabular}{|c|l|l|}
\hline Intensity & Definition & Explanation \\
\hline $\mathbf{1}$ & Equal importance & Two elements contribute equally to the objective \\
\hline $\mathbf{3}$ & Moderate importance & Experience and judgment slightly favor one element over another \\
\hline $\mathbf{5}$ & Strong Importance & $\begin{array}{l}\text { Experience and judgment strongly favor one element over } \\
\text { another }\end{array}$ \\
\hline $\mathbf{7}$ & $\begin{array}{l}\text { Very strong } \\
\text { importance }\end{array}$ & $\begin{array}{l}\text { One element is favored very strongly over another, it dominance } \\
\text { is demonstrated in practice }\end{array}$ \\
\hline $\mathbf{9}$ & Extreme importance & $\begin{array}{l}\text { The evidence favoring one element over another is of the highest } \\
\text { possible order of affirmation }\end{array}$ \\
\hline $2,4,6,8$ can be used to express intermediate values
\end{tabular}




\section{6c) Comparison and Ranking of the Strengths-Threats (S-T) Strategy factors}

AHP Analytic Hierarchy Process (EVM multiple inputs)

K. D. Goepel Version 08.05.2013 http://bpmsg.com

Only input data in the light green fields and worksheets!

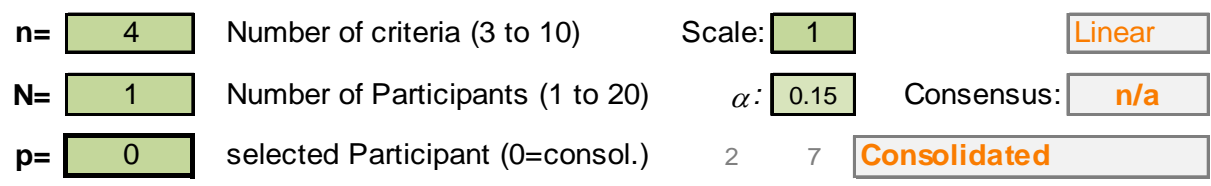

Objective ST Strategy - to increase communitiy participation in ecotourism and improve conservation management

Author

Date

EVM check: $\quad 5.191 \mathrm{E}-08$

\begin{tabular}{|c|c|c|c|c|}
\hline \multirow[t]{7}{*}{ Table } & Criterion & Comment & Weights & $\mathbf{R k}$ \\
\hline & 1 ST1 & \multirow{4}{*}{$\begin{array}{l}\text { alternative ecotourism activities } \\
\text { intensify outreach programmes } \\
\text { local committees to support patrol staff } \\
\text { provide microfinance }\end{array}$} & $57.7 \%$ & 1 \\
\hline & $2 \mathrm{ST} 2$ & & $5.6 \%$ & 4 \\
\hline & 3 ST3 & & $19.3 \%$ & 2 \\
\hline & 4 ST4 & & $17.4 \%$ & 3 \\
\hline & $\begin{array}{l}5 \\
6 \\
7 \\
8\end{array}$ & & & \\
\hline & $\begin{array}{r}9 \\
10\end{array}$ & $\begin{array}{l}\text { for } 9 \& 10 \text { unprotect the input sheets and expand the } \\
\text { question section ("+" in row 66) }\end{array}$ & & \\
\hline
\end{tabular}

Result

Eigenvalue

lambda:

4.260

Consistency Ratio

0.37 GCl: 0.34

$9.5 \%$

Matrix

normalized

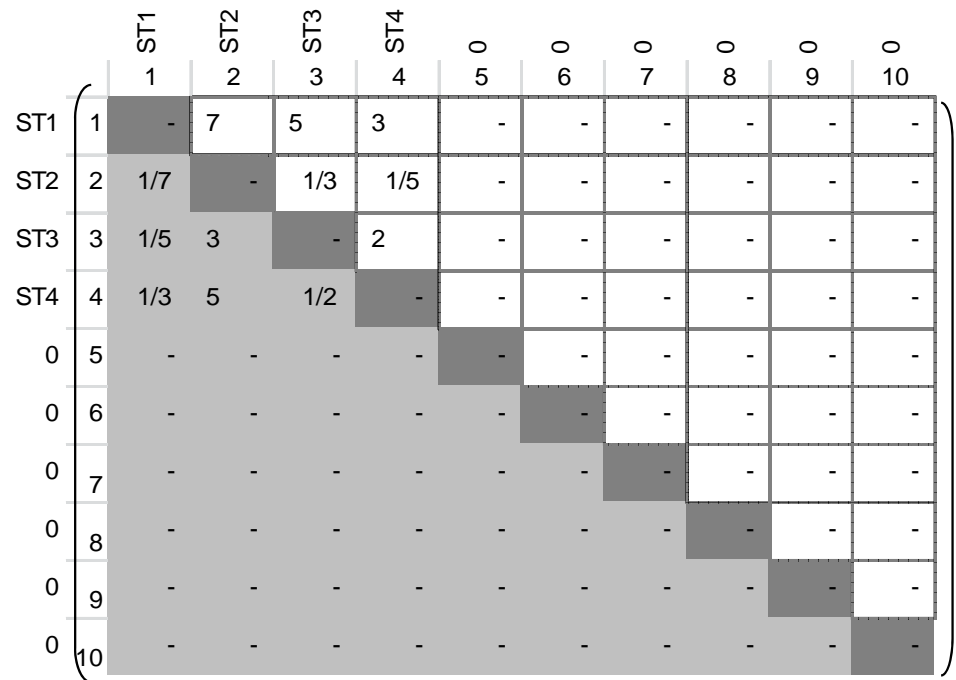

principal

Eigenvector

$\left(\begin{array}{c}57.67 \% \\ 5.57 \% \\ 19.35 \% \\ 17.41 \% \\ 0.00 \% \\ 0.00 \% \\ 0.00 \% \\ 0.00 \% \\ 0.00 \% \\ 0.00 \%\end{array}\right)$




\section{AHP Analytic Hierarchy Process \\ $n=4$ \\ Input 1}

Objective: ST Strategy - to increase communitiy participation in ecotourism and improve conservation manag

Only input data in the light green fields!

Please compare the importance of the elements in relation to the objective and fill in the table: Which

element of each pair is more important, $\mathbf{A}$ or $\mathbf{B}$, and how much more on a scale 1-9 as given below .

Once completed, you might adjust highlighted comparisons 1 to 3 to improve consistency.

\begin{tabular}{|c|l|l|c|}
\hline $\mathrm{n}$ & Criteria & Comment & RGMM \\
\hline 1 & ST1 & alternative ecotourism activities & $58 \%$ \\
2 & ST2 & intensify outreach programmes & $6 \%$ \\
3 & ST3 & local committees to support patrol staff & $19 \%$ \\
4 & ST4 & provide microfinance & $17 \%$ \\
5 & & & \\
6 & & & \\
7 & & & \\
8 & & for 9\&10 unprotect the input sheets and expand the & \\
9 & & question section ("+" in row 66) & \\
10 & &
\end{tabular}

\begin{tabular}{|c|c|c|c|}
\hline Participant 1 & 1 & $9 \%$ & 1 \\
\hline
\end{tabular}

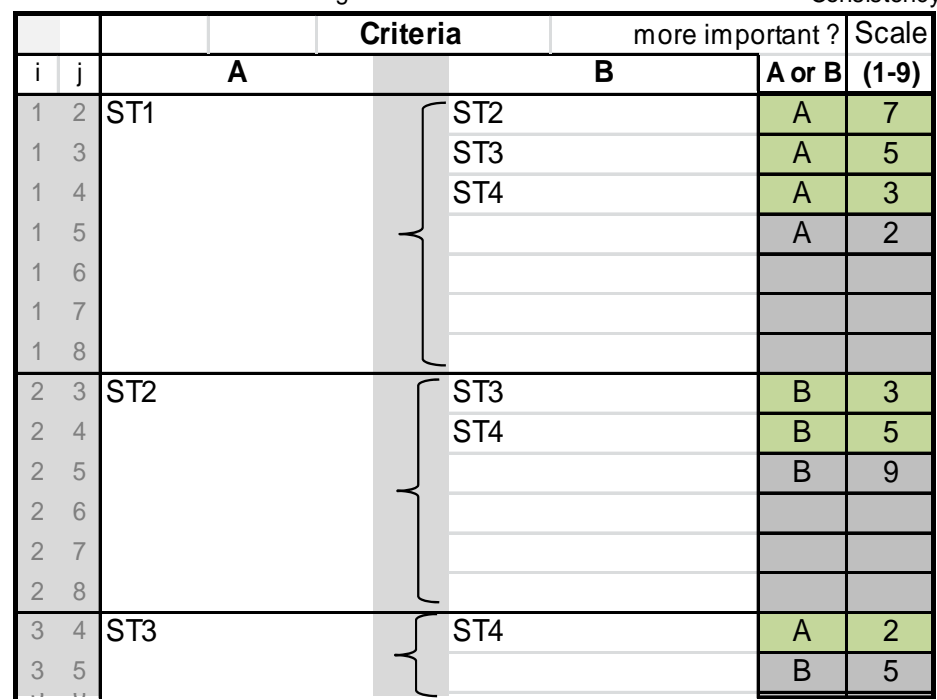

\begin{tabular}{|c|l|l|}
\hline Intensity & Definition & Explanation \\
\hline $\mathbf{1}$ & Equal importance & Two elements contribute equally to the objective \\
\hline $\mathbf{3}$ & $\begin{array}{l}\text { Moderate } \\
\text { importance }\end{array}$ & $\begin{array}{l}\text { Experience and judgment slightly favor one element over } \\
\text { another }\end{array}$ \\
\hline $\mathbf{5}$ & Strong Importance & $\begin{array}{l}\text { Experience and judgment strongly favor one element over } \\
\text { another }\end{array}$ \\
\hline $\mathbf{7}$ & $\begin{array}{l}\text { Very strong } \\
\text { importance }\end{array}$ & $\begin{array}{l}\text { One element is favored very strongly over another, it } \\
\text { dominance is demonstrated in practice }\end{array}$ \\
\hline $\mathbf{9}$ & Extreme importance & $\begin{array}{l}\text { The evidence favoring one element over another is of the } \\
\text { highest possible order of affirmation }\end{array}$ \\
\hline $2,4,6,8$ can be used to express intermediate values
\end{tabular}




\section{6d) Comparison and Ranking of the Weaknesses-Opportunities (W-O) Strategy factors}

AHP Analytic Hierarchy Process (EVM multiple inputs)

K. D. Goepel Version 08.05.2013 http://bpmsg.com

Only input data in the light green fields and worksheets!

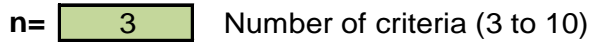
$\mathrm{N}=1$
Number of Participants (1 to 20)
Scale: 1
$p=0$
selected Participant $(0=$ consol.)
$\alpha: 0.15$
Consensus:
Linear

Objective WO Strategy - to increase communitiy participation in ecotourism and improve conservation management

Author Fiagbomeh

Date

EVM check: $5.99098 \mathrm{E}-06$

\begin{tabular}{|l|l|l|c|c|}
\hline \multicolumn{1}{|c|}{ Criterion } & Comment & Weights & Rk \\
\cline { 2 - 5 } & 1 WO1 & wildlife tracking sites & $36.4 \%$ & 2 \\
2 WO2 & elicit protection \& management strategies & $53.7 \%$ & 1 \\
3 WO3 & produce ecotourism management plan & $9.9 \%$ & 3 \\
$\mathbf{4}$ & & & \\
$\mathbf{5}$ & & & \\
$\mathbf{6}$ & & & \\
$\mathbf{7}$ & & & \\
$\mathbf{9}$ & for 9\&10 unprotect the input sheets and expand the & \\
$\mathbf{1 0}$ & question section ("+" in row 66) & & \\
\hline
\end{tabular}

Result

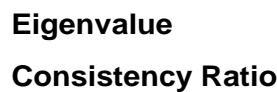

question section ("+" in row 66)

Consistency Ratio

0.37 GCl: 0.28

lambda:

3.094

CR: $9.8 \%$

Matrix

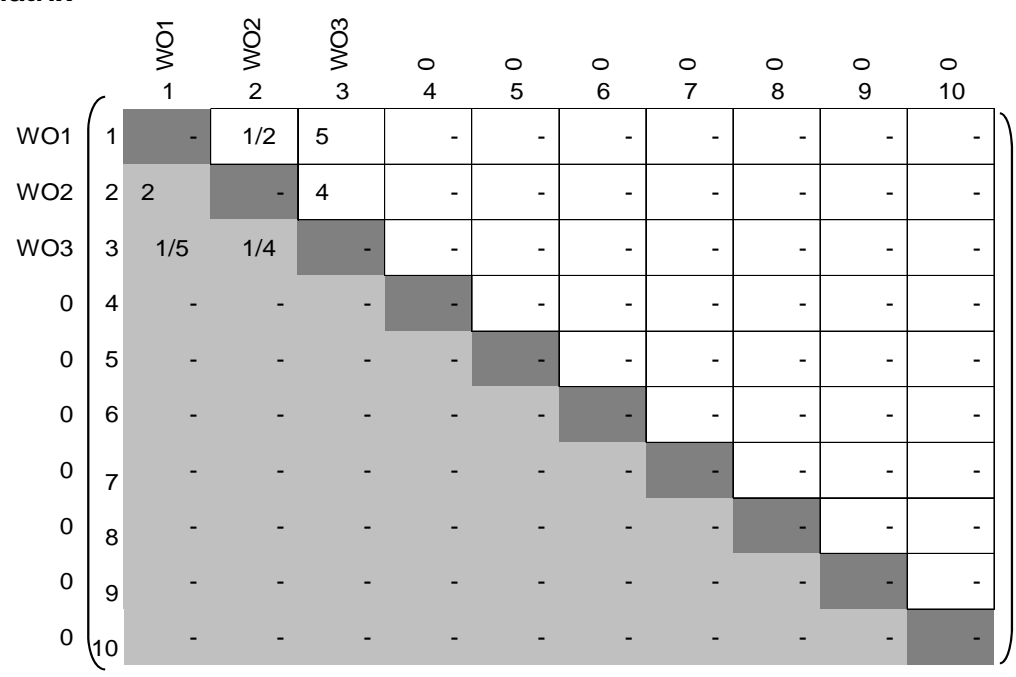

normalized principal Eigenvector

$\left(\begin{array}{c}36.43 \% \\ 53.68 \% \\ 9.89 \% \\ 0.00 \% \\ 0.00 \% \\ 0.00 \% \\ 0.00 \% \\ 0.00 \% \\ 0.00 \% \\ 0.00 \%\end{array}\right)$




\section{AHP Analytic Hierarchy Process \\ $n=3$ \\ Input 1}

Objective: WO Strategy - to increase communitiy participation in ecotourism and improve conservation manager Only input data in the light green fields!

Please compare the importance of the elements in relation to the objective and fill in the table: Which element of each pair is more important, $\mathbf{A}$ or $\mathbf{B}$, and how much more on a scale 1-9 as given below.

Once completed, you might adjust highlighted comparisons 1 to 3 to improve consistency.

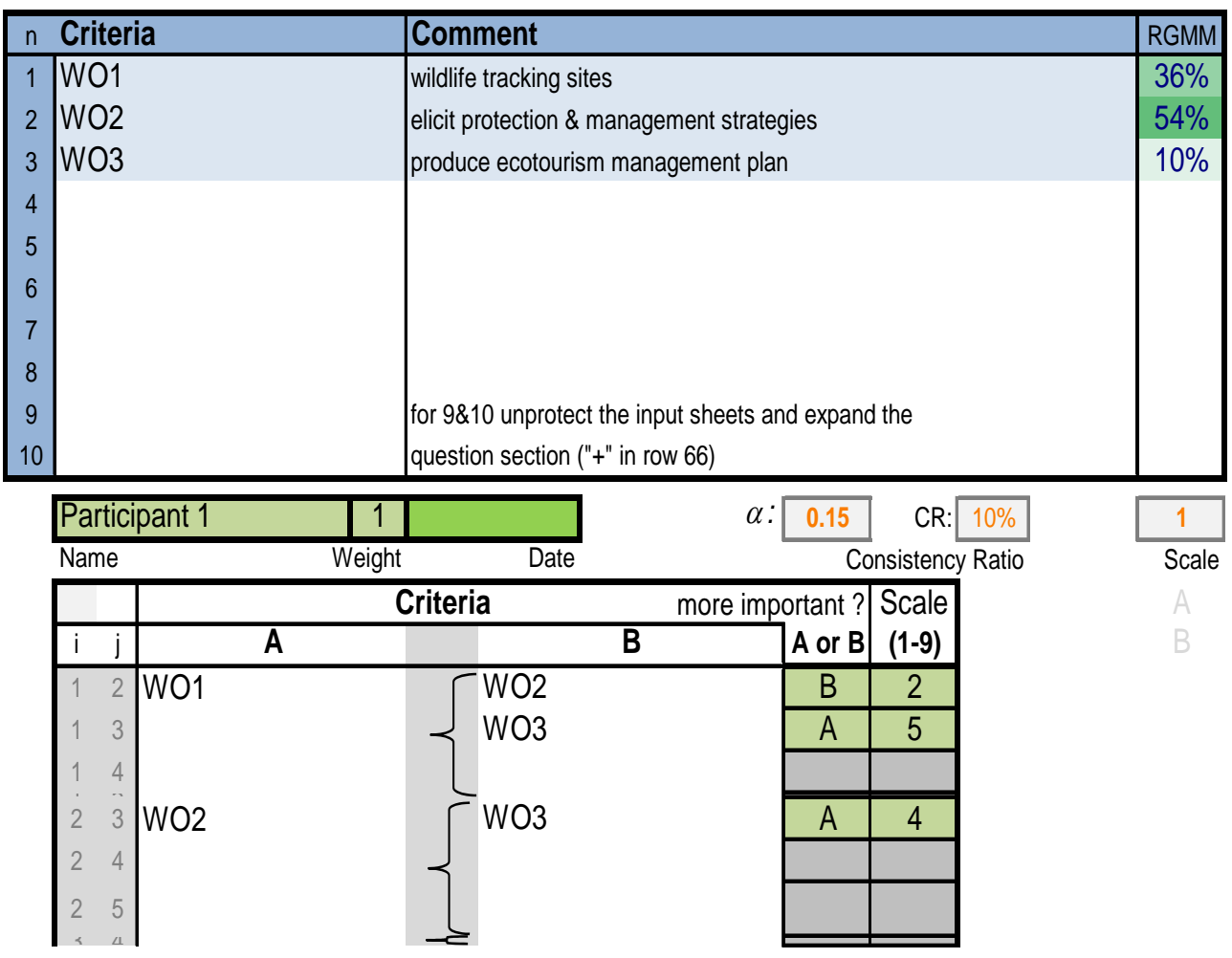

\begin{tabular}{|c|l|l|}
\hline Intensity & Definition & Explanation \\
\hline $\mathbf{1}$ & Equal importance & Two elements contribute equally to the objective \\
\hline $\mathbf{3}$ & Moderate importance & Experience and judgment slightly favor one element over another \\
\hline $\mathbf{5}$ & Strong Importance & $\begin{array}{l}\text { Experience and judgment strongly favor one element over } \\
\text { another }\end{array}$ \\
\hline $\mathbf{7}$ & $\begin{array}{l}\text { Very strong } \\
\text { importance }\end{array}$ & $\begin{array}{l}\text { One element is favored very strongly over another, it dominance } \\
\text { is demonstrated in practice }\end{array}$ \\
\hline $\mathbf{9}$ & Extreme importance & $\begin{array}{l}\text { The evidence favoring one element over another is of the highest } \\
\text { possible order of affirmation }\end{array}$ \\
\hline $2,4,6,8$ can be used to express intermediate values
\end{tabular}




\section{6e) Comparison and Ranking of the Weaknesses-Threats (W-T) Strategy factors}

AHP Analytic Hierarchy Process (EVM multiple inputs)

K. D. Goepel Version 08.05.2013 http://bpmsg.com

Only input data in the light green fields and worksheets!
$\mathbf{n}=4$ Number of criteria (3 to 10)
Scale: 1
Linear
$\mathbf{N}=1$ Number of Participants (1 to 20)
$\alpha: 0.15$ Consensus: $\mathrm{n} / \mathrm{a}$
$p=0$ selected Participant $(0=$ consol. $)$
27 Consolidated

Objective WT Strategy - to increase communitiy participation in ecotourism and improve conservation management

Author

Date

EVM check: $\quad 5.255 \mathrm{E}-08$

\begin{tabular}{|l|l|l|c|c|}
\hline \multicolumn{1}{|c|}{ Criterion } & Comment & Weights & Rk \\
\cline { 2 - 5 } & 1 WT1 & alternative income activities & $28.6 \%$ & 2 \\
2 WT2 & minimum farming distance & $5.0 \%$ & 4 \\
3 WT3 & joint protected area patrol & $6.5 \%$ & 3 \\
4 WT4 & mechanisms to resolve human-wildlife conflicts & $59.9 \%$ & 1 \\
$\mathbf{5}$ & & & \\
$\mathbf{6}$ & & & \\
$\mathbf{7}$ & & & \\
$\mathbf{8}$ & & & \\
$\mathbf{9}$ & for 9\&10 unprotect the input sheets and expand the & \\
$\mathbf{1 0}$ & question section ("+" in row 66) & & \\
\hline
\end{tabular}

\begin{tabular}{llllr|} 
Result & Eigenvalue & & & lambda: \\
Consistency Ratio & 0.37 & GCl: 0.21 & CR:160 & $5.9 \%$ \\
\hline
\end{tabular}

Matrix

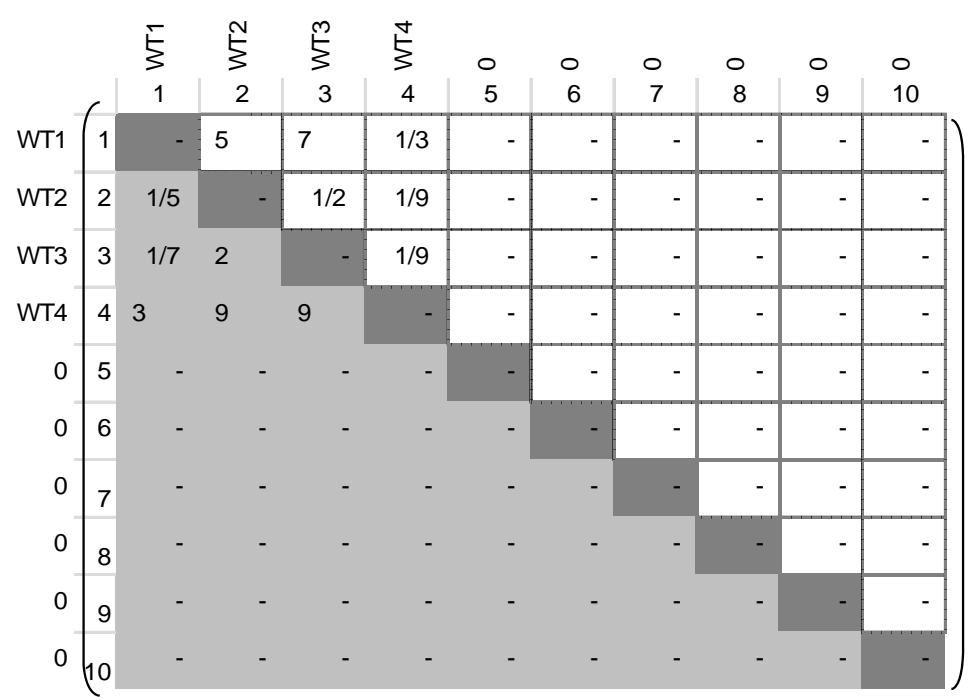

normalized

principal

Eigenvector

$$
\left(\begin{array}{c}
28.63 \% \\
4.95 \% \\
6.53 \% \\
59.89 \% \\
0.00 \% \\
0.00 \% \\
0.00 \% \\
0.00 \% \\
0.00 \% \\
0.00 \%
\end{array}\right)
$$




\section{AHP Analytic Hierarchy Process}

$n=4$

Input 1

Objective: WT Strategy - to increase communitiy participation in ecotourism and improve conservi Only input data in the light green fields!

Please compare the importance of the elements in relation to the objective and fill in the table: Which

element of each pair is more important, $\mathbf{A}$ or $\mathbf{B}$, and how much more on a scale 1-9 as given below .

Once completed, you might adjust highlighted comparisons 1 to 3 to improve consistency.

\begin{tabular}{|c|c|c|c|}
\hline & Criteria & Comment & RGMM \\
\hline 1 & WT1 & alternative income activities & $28 \%$ \\
\hline 2 & WT2 & minimum farming distance & $5 \%$ \\
\hline 3 & WT3 & joint protected area patrol & $6 \%$ \\
\hline 4 & WT4 & mechanisms to resolve human-w ildlife conflicts & $60 \%$ \\
\hline $\begin{array}{c}5 \\
6 \\
7 \\
8 \\
9 \\
10\end{array}$ & & $\begin{array}{l}\text { for } 9 \& 10 \text { unprotect the input sheets and expand the } \\
\text { question section ("+" in row } 66)\end{array}$ & \\
\hline
\end{tabular}

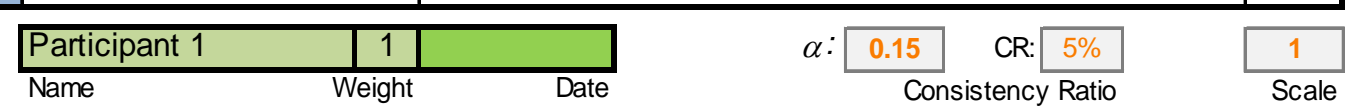

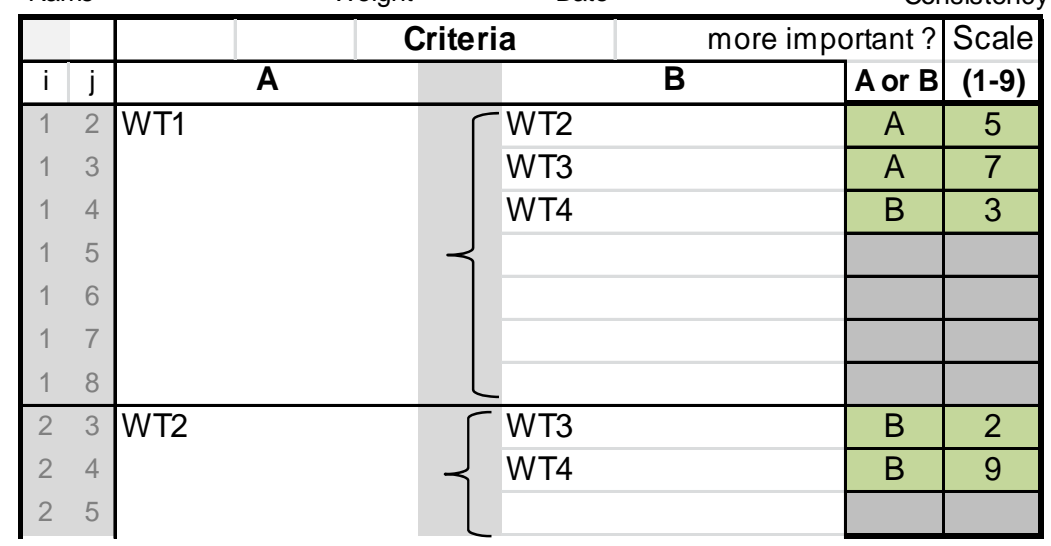

\begin{tabular}{|c|l|l|}
\hline Intensity & Definition & Explanation \\
\hline $\mathbf{1}$ & Equal importance & Two elements contribute equally to the objective \\
\hline $\mathbf{3}$ & $\begin{array}{l}\text { Moderate } \\
\text { importance }\end{array}$ & $\begin{array}{l}\text { Experience and judgment slightly favor one element over } \\
\text { another }\end{array}$ \\
\hline $\mathbf{5}$ & Strong Importance & $\begin{array}{l}\text { Experience and judgment strongly favor one element over } \\
\text { another }\end{array}$ \\
\hline $\mathbf{7}$ & $\begin{array}{l}\text { Very strong } \\
\text { importance }\end{array}$ & $\begin{array}{l}\text { One element is favored very strongly over another, it } \\
\text { dominance is demonstrated in practice }\end{array}$ \\
\hline $\mathbf{9}$ & Extreme importance & $\begin{array}{l}\text { The evidence favoring one element over another is of the } \\
\text { highest possible order of affirmation }\end{array}$ \\
\hline $2,4,6,8$ can be used to express intermediate values \\
\hline
\end{tabular}




\section{6f) Procedure for calculating the Consistency Ratio (CR)}

1. Estimate the Consistency Index $(\mathrm{Cl})$. This is done by adding the columns in the judgment matrix and multiplying the resulting vector by the vector of priorities. This produces and approximation of the maximum eigenvalue, denoted by $\lambda_{\max }$. Then, the $\mathrm{Cl}$ value is calculated using the formula:

$$
\mathrm{Cl}=\frac{\left(\lambda_{\max }-n\right)}{(n-1)} \quad \text { (where } \mathrm{n} \text { is the number of criteria) }
$$

2. The $\mathrm{CR}$ is then obtained by dividing the $\mathrm{Cl}$ value by the corresponding Random Index (RI) as shown below:

$$
\mathrm{CR}=\frac{\mathrm{Cl}}{\mathrm{RI}} \text { (the } \mathrm{RI} \text { values are provided in the table below). }
$$

AHP Analytic Hierarchy Process

Tables

Random Index

\begin{tabular}{|c|c|c|c|c|c|c|c|c|c|c|}
\hline $\mathbf{n}$ & 1 & 2 & 3 & 4 & 5 & 6 & 7 & 8 & 9 & 10 \\
\hline$R I$ & 0.00 & 0.00 & 0.58 & 0.90 & 1.12 & 1.24 & 1.32 & 1.41 & 1.45 & 1.49 \\
\hline CGI & & & 0.31 & 0.35 & 0.37 & 0.37 & 0.37 & 0.37 & 0.37 & 0.37 \\
\hline
\end{tabular}

This table is replaced by calculating CR using Alonso-Lamata linear fit

Scales

\begin{tabular}{|c|l|c|c|c|c|c|c|c|c|c|}
\hline $\mathbf{1}$ & Linear & $\mathbf{1}$ & $\mathbf{2}$ & $\mathbf{3}$ & $\mathbf{4}$ & $\mathbf{5}$ & $\mathbf{6}$ & $\mathbf{7}$ & $\mathbf{8}$ & $\mathbf{9}$ \\
\hline 2 & Log2 & 1 & 1.5849625 & 2 & 2.3219281 & 2.5849625 & 2.8073549 & 3 & 3.169925 & 3.3219281 \\
\hline 3 & Sqrt & 1 & 1.4142136 & 1.7320508 & 2 & 2.236068 & 2.4494897 & 2.6457513 & 2.8284271 & 3 \\
\hline 4 & InvLin & 1 & 1.125 & 1.2857143 & 1.5 & 1.8 & 2.25 & 3 & 4.5 & 9 \\
\hline 5 & Balanced & 1 & 1.2222222 & 1.5 & 1.8571429 & 2.3333333 & 3 & 4 & 5.6666667 & 9 \\
\hline 6 & Power & 1 & 4 & 9 & 16 & 25 & 36 & 49 & 64 & 81 \\
\hline 7 & Geom & 1 & 2 & 4 & 8 & 16 & 32 & 64 & 128 & 256 \\
\hline 8 & Asym & 0 & 0.124355 & 0.2526796 & 0.3897605 & 0.5424915 & 0.7227172 & 0.9555993 & 1.3169579 & 2.6339158 \\
\hline
\end{tabular}

In the current version scales only work for integers 1 to 9 


\section{Appendix Seven:}

\section{Curriculum Vitae}

Personal information

Name

Address

Telephone(s)

E-mail

Nationality

Work experience

Dates

Occupation or position held

Main activities and responsibilities

Name and address of employer

NEPAD Council Internat

May 2006 - June 2008

Programme Administrator

- Administrative duties

- Coordination of Programmes among Partners

- Updating data base for efficient communication and dissemination of information

öttingen, Germany

Tel. +49 5515099283

Type of business or sector

Dates

Occupation or position held Main activities and responsibilities

Name and address of employer

Non-Governmental Organisation (Activity: Business networking)

May 2004 - October 2005; August 1999 - October 2002

Programme Officer

In-charge of Biodiversity and Social Forestry Programmes. Duties included:

- Writing project proposals

- Implementation and coordination of Nature Conservation and Education programmes

- Project monitoring, evaluation and report writing

- Facilitate the organisation of Workshops and seminars

Green Earth Organisation, P. O. Box AN 16641, Accra Ghana

Tel. +233208184091

Non-Governmental Environment and Development Organisation 


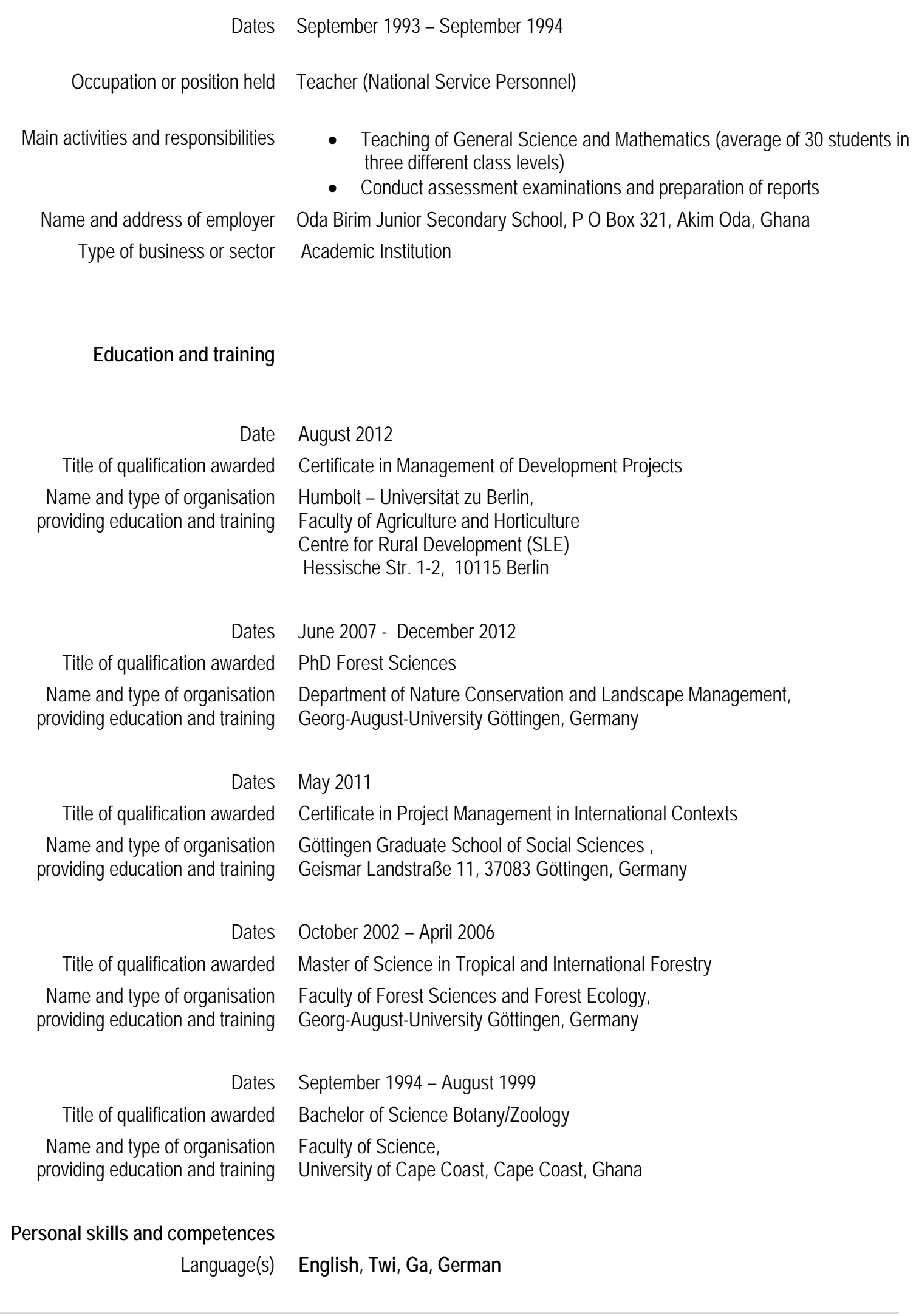


Social skills and competences
Organisational skills and competences

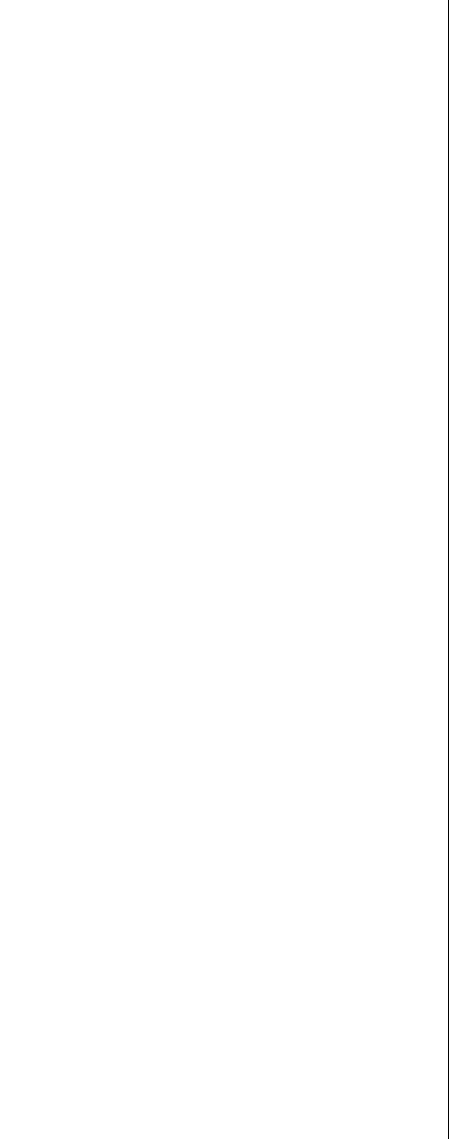

Computer skills and competences
- $\quad$ Team work: I have worked in teams from academic groups to religious organisations and environmental clubs. For 2 years, I was a member of the coordination team of the National Union of Presbyterian Students of Ghana (NUPSG), University of Cape Coast (UCC) branch; I was also a founding member and general secretary of the Green Earth Club of UCC for 3 years

RESEARCH AND DATA COLLECTION EXPERIENCE:

- 10/2008 - 02/2009: Principal Researcher. Designed and conducted field data collection in rural communities on the topic "Dimensions of the Impacts of Ecotourism. A Case Study in the Kakum Conservation Area, Ghana".

- I organised group discussions and interviews with local people and traditional authorities on ecotourism and protected area management; survey of tourists at Kakum visitor centre.

\section{FUNDED PROJECTS IMPLEMENTED AND COORDINATED:}

- 2001-2002: Integrated Forest Conservation and Bushfire Prevention Education Project, Brong-Ahafo Region, Ghana. (Sponsor: The Netherlands Embassy in Ghana; Implementing Institution: Green Earth Organization, Accra).

- 2000-2002: Songor Wetland Management and Conservation Education Project, Ada, Greater Accra Region, Ghana (Sponsor: IUCN; Implementing Institution: Green Earth Organization).

- 09/2002: Assigned by IBIS to assess and recommend Community Based Organizations (CBOs) in the Bawku District of Upper East Region of Ghana for financial support and capacity development.

- Whilst working for Green Earth Organisation, I assisted in organising round table discussion on Agricultural Policies and Forest Conservation in Ghana (06/2000); workshop on Forest Conservation, theme: Effective Participation of Rural Communities in Forest Biodiversity Conservation in Ghana (10/2000).

- Competent with Microsoft Office programmes (Word, Excel, Power Point)

- Proficient in the use of data analysis programmes: SPSS, R, GraphPad Prism 5 